$56(777)-$

$56(112)$

\title{
TRILOBITES OF IOWA AND SOME RELATED PALEOZOIC FORMS





\section{CONTENTS}

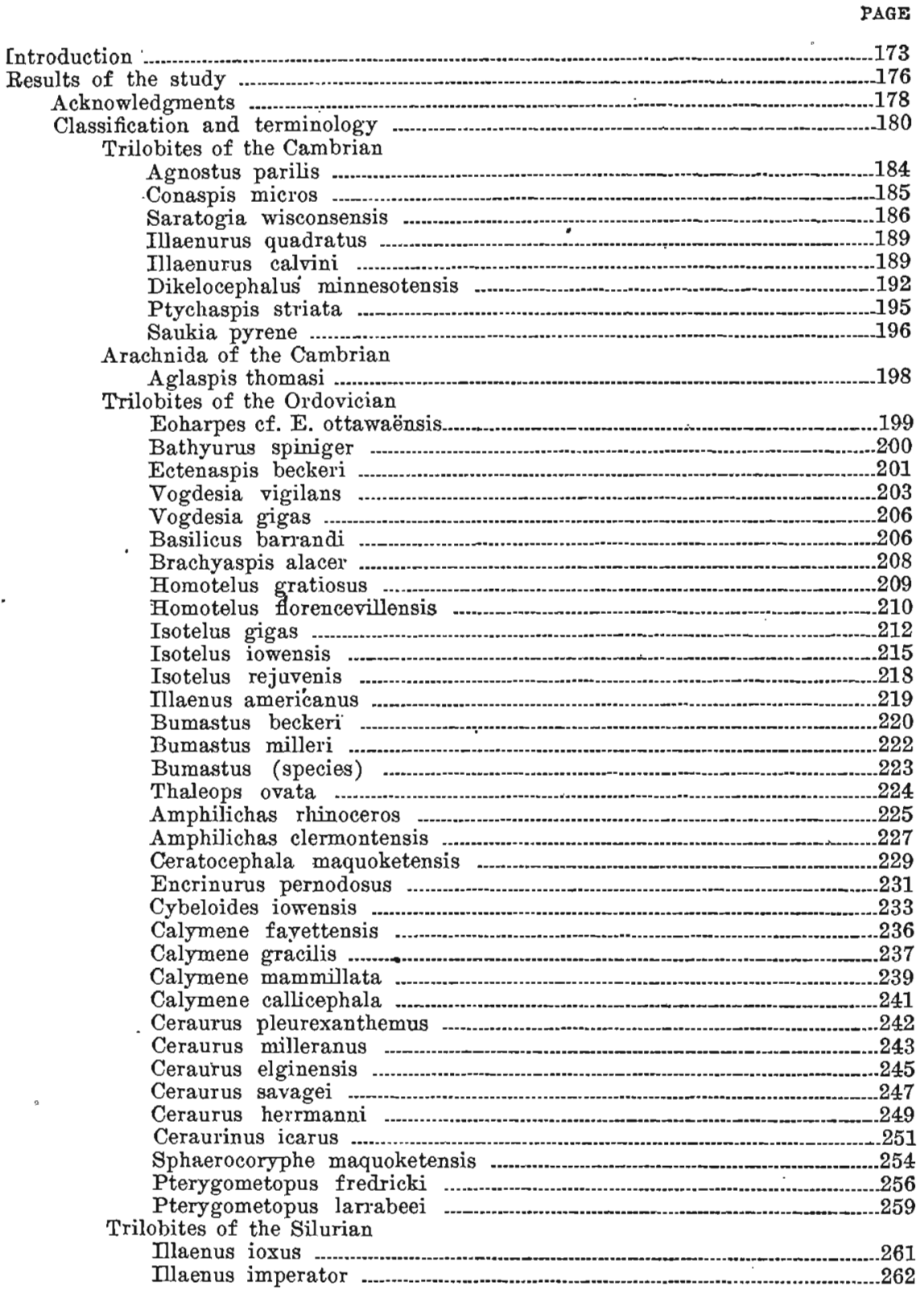


Mlaenus slocomi

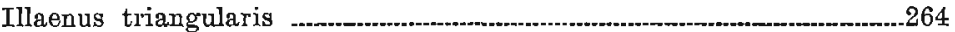

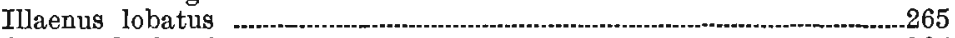

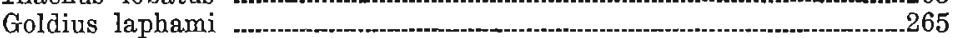

Arctinurus (Metopolichas) obvius _..______ 267

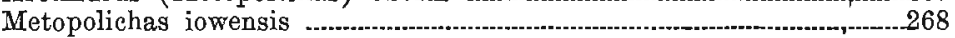

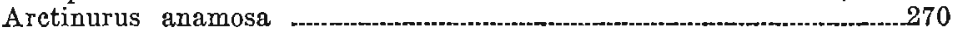

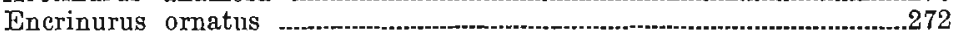

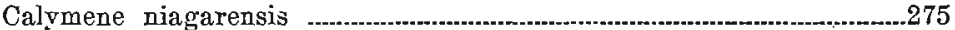

Cheirurus niagarensis _..__

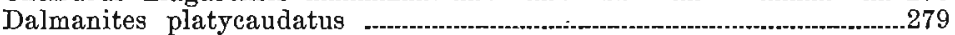

Trilobites of the Devonian

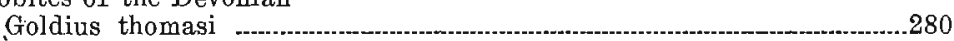

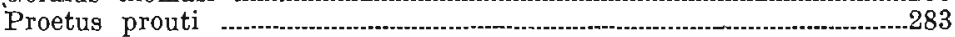

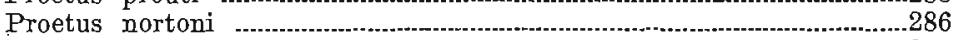

Proetus clarus

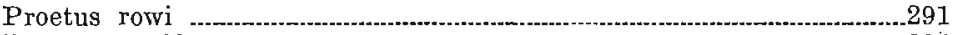

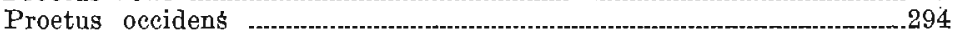

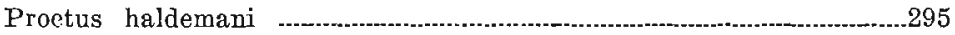

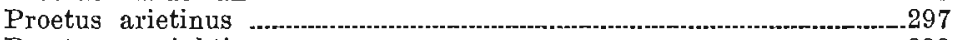

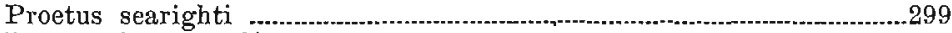

Proetus bumastoidés ..............................._.

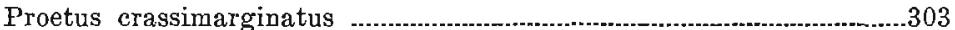

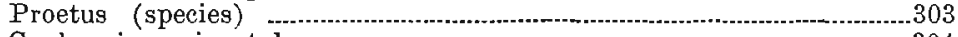

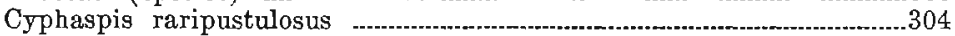

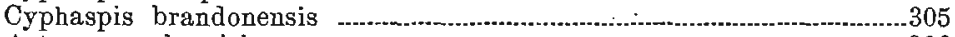

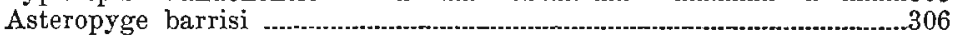

Asteropyge fitzpatricki ...................................................................307

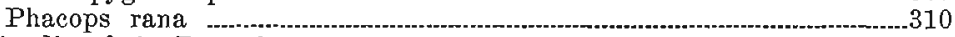

Cirripedia of the Devonian

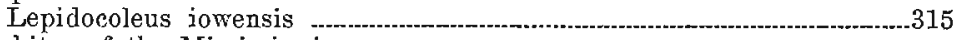

Trilobites of the Mississippian

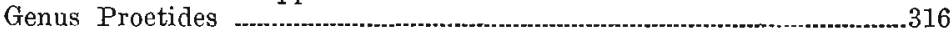

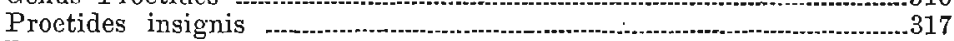

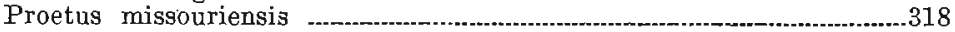

Phillipsia tuberculata ..........._._._.

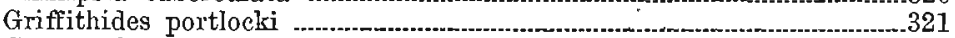

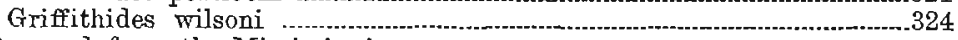

A Decapod from the Mississippian

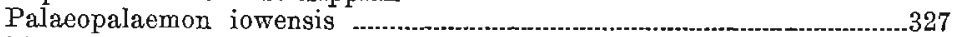

Trilobites of the Pennsylvanian

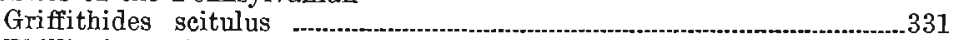

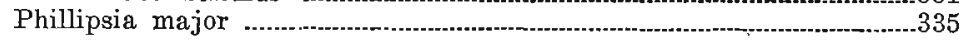

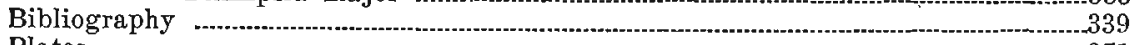

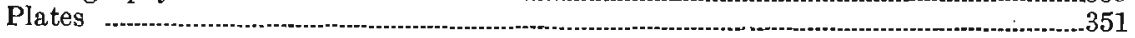




\section{LIST OF ILLUSTRATIONS}

X. Figures 1-9, Dikelocephalus minnesotensis; 10, 11, Agnostus parilis;

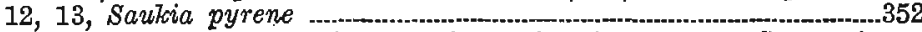

XI. Eigures 1-4, Aglaspis thomasi; 5, 6, Conaspis mioros; 7-10, Saratogia wisconsensis; 11-14, Ptychaspis striata; 15-20, Illaenurus calvini.-.-354

XII. Figure 1, Agnostus parilis; 2, Conaspis micros; 3, 4, Ptychaspis striata.356

XIII. Figures 1, 2, Eoharpes cf. E. ottawaënsis, 3-5, Homotelus florencevillensis; 6, 7, Bathyurus spiniger; 8, 9, Ectenaspis beckeri........358

XIV. Figures 1-8, Brachyaspis alacer; 9,10 , Brachyaspis sp. .......................360

XV. Figures 1-3, Isotelus gigas; 4, 5, Vogdesia 'gigas ..._._._._._._._._._._.

XVI. Figures 1-5, Vogdesia vigilans; 6-10, Isotelus iowensis; $11, B$ Bsilicus barrandi

XVII. Figure 1, Illaemus americamus; 2, Bumastus milleri; 3-5, Thaleops ovata; 6,7, Homotelus gratiosus; 8,9 , Isotelus rejuvenis _........ 366

XVIII. Figure 1, Cybeloides iowensis; 2, 3, Ceratocephala maquoketensis; 4-6, Encrinurus pernodosus; 7, 8, Amphilichas rhinoceros; 9, A. clermontensis; 10, 11, Bumastus beckeri; 12, Bumastus sp.

XIX. Figures 1-3, Calymene mammillata; 4-6, C. fayettensis; 7, 8, C. gracilis; 9, 17, Ceraurus pleurexanthemus; 10, C. elginensis; 11-15, C.

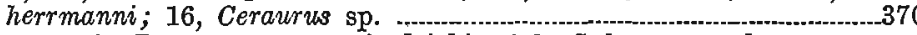

XX. Figures 1-3, Pterygometopus fredricki; 4-6, Sphaerocoryphe maquoketensis; 7, Ceraurus milleranus; 8, 9, Pterygometopus larrabeei; 10-13, Ceraurinus icarus

XXI. Figures 1-3, Illaenus imperator; 4-6, I. slocomi; 7, 8, I. lobatus ...........374

XXII. Figure 1, Illaenus ioxus; 2-4, I. triangularis; 5-7, Goldius laphami ......376

XXIII. Figures 1, 2, Metopolichas iowensis; 3, M. obvins; 4-8, Arctimurus anamosa; 10, Dalmanites platycandatus; 11-15, Encrimurus ornatus

XXIV. Figures 1-5, Calymene niagarensis; 6, Cheirurus niagarensis; 7, Cybele

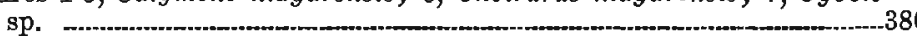

XXV. Figure 1, Ceraurus savagei; 2-4, Goldius thomasi; 5-8, Proetus prouti; 9-11, P. nortoni; 12, 13, P. olarus; 14, 15, P. rowi; 16, 17, P. oo cidens; $18,19, P$. haldemani; 20 , Proetus sp.; 21,22 , $P$. arietinus;

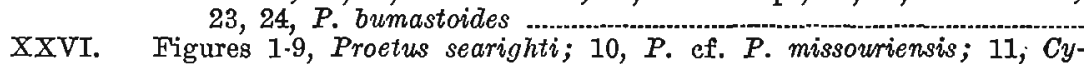
phaspis raripustulosus; $12, C$. brandonensis; 13-17, Proetides insignis; 18, Asteropyge barrisi; 19-21, A. fitgpatricki; 22, Phillipsia tuberculata; 23-26, Phacops rana; $27,28, P$. major

XXVII. Figures 1-8, Griffithides wilsoni; 9, 10, G. wilsoni var. jenevievensis;
11-14, G. soitulus; 15, 16, Lepidocoleus iowensis; 17-19, Griffith-

XXVII. Figures 1-8, Griffithides wilsoni; 9, 10, G. wilsoni var. jenevievensis;
11-14, G. soitulus; 15, 16, Lepidocoleus iowensis; 17-19, Griffithides portlocki; 20, Palaeopalaemon iowensis; 21, Isotelus gigas;

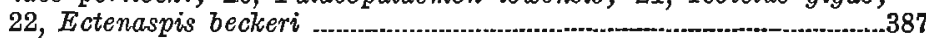

FIGURE

23. Chronological table of the strata of Iowa

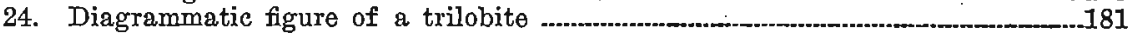

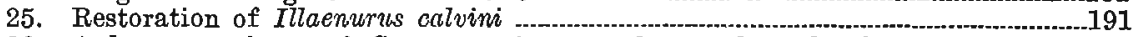

26. A large specimen of Ceraurus pleurexanthemus from Boyle's quarry near

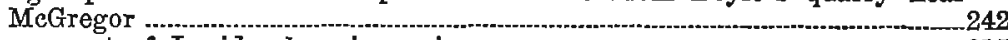

27. Enlargement of Lepidocoleus iowensis ....

28. Griffithides scitulus. Two well preserved specimens from Pennsylvanian limestone near Fort Dodge 


$$
\text { - }
$$




\section{TRILOBITES OF IOWA}

\section{Introduction}

The study of the trilobites of Iowa and of some of the related forms is an attempt to bring together all the work of previous writers and collectors who have contributed in any way to, our knowledge of these Paleozoic Arthropods. No work of this kind, including all the trilobites of the Paleozoic of Iowa, has ever before been attempted. The notes and lists made by the authors of the various county reports and of other workers have. been more or less abundant but they have been scattered and withal only incidental to the geologic problems under investigation by them.

Slocom, ${ }^{1}$ however, forms an outstanding exception to this general statement for he made an excellent beginning in this work by his investigations of the "Trilobites of the Maquoketa Beds of Fayette County, Iowa". In this report twenty species of trilobites are described and twelve of these were found by him to be new.

The nucleus of the material available for the present study was the Samuel Calvin collection and to some extent the.C. A. White collection, both at the State University of Iowa. The former especially represents many years of careful collecting and embodies much reliable information concerning exact horizons and localities. In addition to the Calyin collection the writer has had free access to an excellent collection belonging to Professor T. J. Fitzpatrick; to a fairly complete collection of Maquoketa fossils helonging to Mr. A. G. Becker and to his late father Dr. Fredrick Becker; to the collections of Mr. Richard Herrmann in the Herrmann Museum at Dubuque; to the collections of: the Davenport Academy of Science and of St. Ambrose College, both of Davenport; and to the collections of the State Historical Department at Des Moines.

A circular letter was addressed to many institutions and individuals in the state asking for opportunity to study any: Iowa

1 Slocom, Field Mus. Nat. Hist., No.. 171, Geol. Ser., vol. 4, No. 3, pp. 43-89, plates 13-18, 1913. Also Iowa Geol. Survey; 'vol: XXV; pp. '183-250; plates XIV-XIX, 1916. 
trilobite material in their possession or care. Without exception a courteous response and a willingness to co-operate in the investigation mark the replies received.

During the summer of 1921 the writer in company with Dr. A. O. Thomas engaged in an intensive collecting trip throughout the northeastern part of the state, visiting nearly' all the horizons from the Cambrian to the Devonian and nearly all the localities from which trilobites have ever been recorded in county reports and other papers, as well as many new localities. This trip added greatly to a more refined knowledge of the mode of preservation, occurrence and distribution of many of our trilobites. Later in the season three weeks were spent in the vicinity of Dubuque collecting in the Platteville and Galena. Again during the summer of 1922 the writer in company with Mr. Ben $\mathrm{H}$. Wilson made an extensive collecting trip through the southeastern part of the state visiting the younger Paleozoic systems and localities from which trilobites have been reported. Some of these localities are Mount Pleasant, Fort Madison, Burlington, Montrose and Keokuk. The Devonian outcrops in the ricinity of Iowa City, Solon and Linn Junction have been visited on several occasions.

Seventy-nine species of trilobites have been established for the state. Nineteen, or twenty-four per cent, of these are new. But the writer feels fully convinced that further collecting in Iowa will not only add more new species but also will reveal additional species already known outside of the state and thus perhaps double the number of species now known from Iowa. There also remains an open field for the study of Ostracods, Phyllocarids and Echinocarids. Fragmentary remains of the last have been encountered on numerous occasions. Phyllocarids are known from the Sweetland Creek shales, the stratigraphic position of which is somewhat problematical at the present time. Ostracods are exceedingly numerous at certain horizons throughout the Paleozoic of the state.

In the main the classification of trilobites as it appears in the English edition of the Zittel-Eastman Textbook of Paleontology, volume 1, 1913, has been followed. However, in those instances where revisions of old genera have been made, or where new genera have been added since the publication of Zittel's. textbook 
the revised classification is adopted and the new generic names are used in order to bring the classification up to date.

\begin{tabular}{|c|c|c|c|c|c|}
\hline SWSTES & SERIES & FORMATION & $\begin{array}{l}\text { COLUMNAR } \\
\text { SECTION }\end{array}$ & Thetnest & Character of Roafs \\
\hline \multirow{4}{*}{ 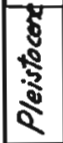 } & \multirow{4}{*}{$\begin{array}{l}\text { Wisconsin } \\
\text { Towas } \\
\text { Illingian } \\
\text { Tonsar } \\
\text { Nebrostan }\end{array}$} & & 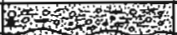 & & \\
\hline & & & & & \\
\hline & & & 要 & & \\
\hline & & & 18 & & \\
\hline \multirow{2}{*}{ (5: } & \multirow{2}{*}{ UpperCretaceous } & Colorado & & 150 & $\begin{array}{l}\text { Spoles wigh sof cholky } \\
\text { Simestones }\end{array}$ \\
\hline & & Dakota & & 100. & Sandstane \\
\hline 6: & \multirow[b]{2}{*}{. } & \multirow{2}{*}{ Fort Dodga } & & 50 & Sandy shate and sandstore \\
\hline & & & & 30 & Gypsum \\
\hline \multirow{6}{*}{ } & \multirow{3}{*}{ Missouri } & Ggoovariar & & $\frac{108}{233}$ & $\begin{array}{l}\text { Share ond limestone } \\
\text { Limestong and shate }\end{array}$ \\
\hline & & sho & & $\frac{233}{26}$ & $\begin{array}{l}\text { Limestone and shate } \\
\text { Limestone and shale }\end{array}$ \\
\hline & & 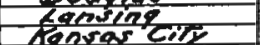 & & $\frac{34}{131}$ & $\begin{array}{l}\text { Limestone ond shale } \\
\text { Limestons and sharla }\end{array}$ \\
\hline & \multirow{3}{*}{ Des Moines } & pleasentes & 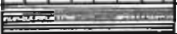 & & Shale and sandstond \\
\hline & & Henrietto & 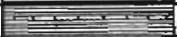 & 750 & Shale and sandstane \\
\hline & & cherotee & tit & & Shake, sandstone, coal. \\
\hline \multirow{4}{*}{. } & \multirow{2}{*}{ Meramec } & Str.6angvieve & F & $0-40$ & Limestone \\
\hline & & spergen & 㯺 & $35-105$ & Limestone \\
\hline & Osage & heofink & & $150-2 / 5$ & L/mestone \\
\hline & Kindertionk & & & 150 & Shale and sandstone \\
\hline \multirow{3}{*}{$\begin{array}{c}5 \\
\vdots \\
5 \\
0 \\
0\end{array}$} & \multirow{3}{*}{ UpperDevonian } & Shate - Lime & & $40-120$ & Limestone Shale \\
\hline & & Cedar Kaller & & 100 & $\begin{array}{l}\text { Limestome shaly limestone. } \\
\text { Some doiomite in the } \\
\text { northern counlies. }\end{array}$ \\
\hline & & Wopsipinicon & & $60-75$ & $\begin{array}{l}\text { Limestones, shales and } \\
\text { shaly timestones. }\end{array}$ \\
\hline \multirow{3}{*}{$\begin{array}{l}5 \\
\vdots \\
\vdots \\
\vdots \\
\vdots \\
y\end{array}$} & \multirow[b]{2}{*}{ Niagaran } & - Gower & & 120 & Dolomire \\
\hline & & Hoprinton & & 220 & $\begin{array}{l}\text { Dolomite very } \\
\text { posslifferous in places. }\end{array}$ \\
\hline & Rlexandrian & & & $0-40$ & Zimestone ond dotomite. \\
\hline \multirow{7}{*}{ 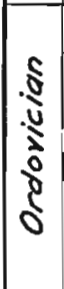 } & Cincinnation & Maguaketa & & 200 & $\begin{array}{l}\text { Dork sholes, shofy limestiones, } \\
\text { and locally, beds of dofomile. }\end{array}$ \\
\hline & \multirow{3}{*}{ Motawtian } & Golena & 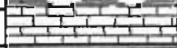 & 340 & $\begin{array}{l}\text { Oolomitechiotylinploces } \\
\text { unaltered jimstone. }\end{array}$ \\
\hline & & Decorat & & $0-40$ & Sholes with thin bed's of fineston \\
\hline & & Platterille & 工工工工工工工工工工 & 90 & Marly fimostomes and sholes. \\
\hline & \multirow{3}{*}{ Canadian } & St Peter & & $80-160$ & Sandstane \\
\hline & & in shakepre & +4 & $20-80$ & Dolomite \\
\hline & & dus Oneato & 年 & 150 & Dolanite \\
\hline \multirow{3}{*}{ 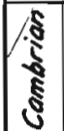 } & \multirow{3}{*}{ Croixan } & clordan & की & 100 & Coarse sardstone \\
\hline & & st Lawrence & ring & 50 & Dolomite, sandy \\
\hline & & Dresbach & की & & $\begin{array}{l}\text { Sandstone werth bands of: } \\
\text { glauconite }\end{array}$ \\
\hline $\begin{array}{l}\text { Ahont } \\
\text { tions }\end{array}$ & Huronian & Sioux Puortite & 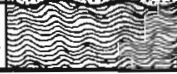 & & Quarizite \\
\hline
\end{tabular}

Wru. 23.-Chronological table of thie Paleozoic rocks of Yowa. Adapted from Jesse V. Howell, Iowa Geol. Survey, vol. XXIX, Ann. Reports for 1919 and 1920, p. 20.

The writer has refraineci as much as possible from estahlishing ncw species on inadequate material. Erection of species on 
pygidia alone is ill-advised and has been resorted to in only a few cases. As a general rule it is unwise to give generic or specific rank to forms the cephalic characters of which are uncertain or entirely wanting. A perusal of the literature on trilobites reveals far too many instances in which species and even genera based on pygidia do cause confusion. In the opinion of the writer this practice should be resorted to with extreme caution.

It has been deeined inadvisable to give family and generic definitions except in the case of Proetides, a new genus, and of Conaspis, which is not given in ordinary texts such as Zittel, Grabau and Shimer, and others.

The bibliography listed for the various species is not intended to be complete or exhaustive except in cases where it was necessary to give the full synonymy of those forms whose generic reference has been changed since the founding of the species. In all other cases only as much of the bibliography is quoted as seemed relevant to an accurate understanding of the Iowa material and its history. A more extended bibliography seems to the writer not only superfluous but also an unnecessary repetition in view of the fact that Vogdes ${ }^{\prime 2}$, Bassler's ${ }^{3}$ and Weller's ${ }^{4}$ bibliographies are readily available to students of trilobites.

In cases where a species was formerly reported from the state but where the specimen was not collected or seen by the writer the original description is used here for the sake of completeness. In cases where the material was identifiable but too poor or frapmentary for description a similar method was pursued, and in those cases where earlier descriptions are deemed adequate, even though good material was at hand, the earlier descriptions have been freely drawn upon and due credit has been given in all cases.

\section{Results of the study}

1. The study has resulted in establishing for the state seventynine species of trilobites, one species of an arachnid, one species

2 Vodges, Bibliography of Paleozoic Crustacea: California Acad. Sci.., San Francisco, 1913. Also Paleozoic Crustacea: Trans. San Diego Soc. Nat. Hist., San Diego, Cal., July, 1917.

3 Bassler, Bibliographic Index of American Ordovician and Silurian Fossils: Smithsonian Institution, $U$. $S$. National Mus. $B$ ull. 92 , vols. 1 and 2,1915

4 Weller; Bibliographic Indéx of North Anierican Carboniferoús I'nvertebrates: United States Geological Survey, Bull. 153, 1898 . 
of a cirriped, and one species of a decapod crustacean. Of the seventy-nine species of trilobites, mineteen, or twenty-four per cent, are new. From one to eight species in each system of rocks except the Pennsylvanian and the Permian were found to be new. In the former system only two species of trilobites were encountered and the latter or Permian system is unfossiliferous in Iowa with the exception of such fossils as occur in the pebbles of a basal conglomerate below the gypsum near Fort Dodge. The arachnid is new also and the cirriped from the Lime Creek beds is here described as new by Dr: A. O. Thomas.

2. Of these seventy-nine species found in the state thirty-nine represent Iowa types and the remaining forty were originally described from specimens found outside of Iowa. The present location of the types is denoted under each species.

3. The seventy-nine species are distributed through thirtyeight genera. Of these genera Proetides is new and thirteen are recorded for the first time as occurring in the state.

4. The following new trilobite-yielding localities have been added: The Eau Claire formation about half a mile south of Lansing; a Dikelocephalus minnesotensis horizon three miles west of Lansing; an Isotelus zone in the southeast quarter of the northwest quarter of section 9, Madison township, Winneshiek county; a Ceraurus zone in the Platteville along Sny Magill creek, Clayton county; an Eoharpes zone in the Platteville limestone at Boyle's quarry near McGregor and in the Platterille limestone near Dubuque; the Griffithides wilsoni horizon in the Pella beds at Mt. Pleasant, Ottumwa, Fremont and Ollie; the Griffithides scitulus horizon in the Henrietta limestone at Des Moines.

5. Many of the trilobites have a definite stratigraphic value as horizon markers of exposed strata and can now be so used in the state. A few examples are cited as an illustration: Dikelocephalus minnesotensis is limited to a narrow zone near the base of the St. Lawrence limestone; Saratogia wisconsensis and Ptychaspis striata are fairly common but in Iowa are limited to the Eau Claire formation; Calymiene mammillata is found only in the Lower Maquoketa near Graf; Calymene gracilis definitely marks the upper layers of the Upper Maquoketa at Pattersons Springs 
near Brainard and elsewhere; the different species of Isotelus are limited to the Isotelus zone of the Lower Maquoketa; Encrinurus ornatus is the type fossil of the Anamosa-LeClaire formation; Proetus prouti has a comparatively wide areal distribution in the Devonian but stratigraphically it is limited to the basal Cedar Valley; Goldius thomasi is limited to a narrow zone in the Owen substage of the Lime Creek shales; Cyphaspis brandonensis definitely marks the Independence shale; Griffithides wilsoni is an excellent index fossil of the Pella beds. Phillipsia tuberculata is a trilobite peculiar to the Burlington limestone and is the first trilobite ever reported in Iowa from this highly fossiliferous formation; Griffithides scitulus is a guide fossil of the Des Moines shaly limestone and Phillipsia major is a guide fossil of the Tarkio limestone.

6. Panderian organs, which are only rarely observed in trilobites, have been found on two Iowa specimens, namely Isotelus gigas and Ectenaspis beckeri.

\section{Acknowledgments}

The writer wishes at this time to express his sincere appreciation of the assistance of Mr. A. G. Becker of Clermont. With enthusiastic interest he made available for study his fine collection of Maquoketa fossils as well as that of his late father, Dr. Fredrick Becker. He not only cheerfully gave valuable information but rendered most valuable personal service in conducting collecting excursions to the famous localities in Fayettc county, with which he is most intimately familiar.

The writer is also much indebted to Dr. G. M. Ehlers for the loan of specimens from the paleontologic collection at the University of Michigan, to.Mr. Edgar R. Harlan, curator of the State Historical Department at Des Moines, for the loan of a specimen of Phillipsia tuberculata and to Mr. G. A. Larson of Des Moines for his recent gift to the University of several fine specimens of Griffithides wilsoni from the Pella beds at Ottumwa.

Dr. W. H. Norton of Cornell College generously loaned a fine set of Encrinurus ornatus, collected at Mt. Vernon, and to him is credited a beautiful new species of Proetus from Linin and Janesville. 
The writer has been greatly favored by the courtesy and interest of Prof: T. J. Fitzpatrick, who placed his entire collection of fine and rare trilobites at the writer's disposal, giving exact information concerning horizons and localities: Much credit is due his generous spirit in aiding the progress of this work.

Grateful acknowledgment is due Father Ulrich Hauber, of St. Ambrose College at Davenport, who spent several delightful days in the field with the writer collecting material which he presented to the State University of Iowa for study; and for the delightful hospitality which the writer enjoyed at St. Ambrose College during his stay at Davenport.

The writer is greatly indebted to Mr. Ben H. Wilson of Mount Pleasant for his untiring devotion to, our work. He examined many private, college and museum collections for material that would enhance and add to the completeness of the investigation. Especially does the writer wish to express his gratitude to Mr. Wilson for the helpful and successful trip taken with him in the summer of 1922 to all the noted trilobite localities in southeastern Iowa, with which Mr. Wilson is well acquainted.

An expression of admiration is here recorded for the pioneer work of Mr. Richard Herrmann of Dubuque and his family who, side by side with a business career, have found inspiration in studying "the yesterdays" of human and geologic history. They have gathered around them directly and indirectly and with untiring patience and effort a large body of valuable and interesting facts as well as a great variety of museum specimens-constituting the Richard Herrmann Museum-the trilobites from which were freely placed at the writer's disposal.

The writer also wishes to acknowledge the splendid spirit of coöperation shown by Dr. Charles D. Walcott, Dr. Percy E. Raymond, Mr. Arthur Ware Slocom, and Dr. Aug. F. Foerste in the identification of specimens submitted to them. Their help has contributed greatly to bringing the classification up to date.

In having made the acquaintance, through correspondence, of the able scholar and paleontologist, Dr. George H. Girty, the writer feels that he has been especially favored. The Carboniferous fossils which were submitted to Doctor Girty for verification or identification were taken up one by one with the most 
thorough and painstaking efforts and discussion was invited. It has been a peculiar pleasure indeed to consider difficult problems with one who left nothing to guesswork but who exhausted every possibility to arrive at positive scientific truth.

- In addition acknowledgment is due the different members of the staff of the Department of Geology of the State University of Iowa, all of whom have contributed directly and indirectly with material, counsel and advice to the work in progress, and to the students of the paleontology.classes, who have most enthusiastically contributed to the, writer for study their findings on their various field trips. Further mention of these students is made in the discussion of the species.

Grateful acknowledgment and recognition of her efficiency is given to Miss Jane E. Roberts, former librarian, who coöperated most cheerfully for a period of two and one-half years in securing many valuable and indispensable publications from reference libraries and from various institutions.

And finally I wish to pay tribute to Dr. A. O. Thomas, a scholar, friend and untiring co-worker. His counsel, leadership and interest in the preparation of this work have not only been a source of continual pleasure and inspiration throughout a period of three years but also have taught the writer the method and secret of scientific investigation.

The classification and terminology is copied from Slocom's report which appeared in volume $\mathrm{xxv}$ of this series.

\section{Classification and Terminology.}

The classification here used is that prepared by Prof. Charles E. Beecher and given in the English edition of Zittel's Textbook of.Paleontology. For definitions of the various orders and families the reader is referred to that work.

In order to make clear in what sense various terms are used by the writer, the following glossary is' given. The letters or figures in parentheses refer to text figure 24.

Annulations: The ringlike divisions of the axis' of the pygidium. (13) 


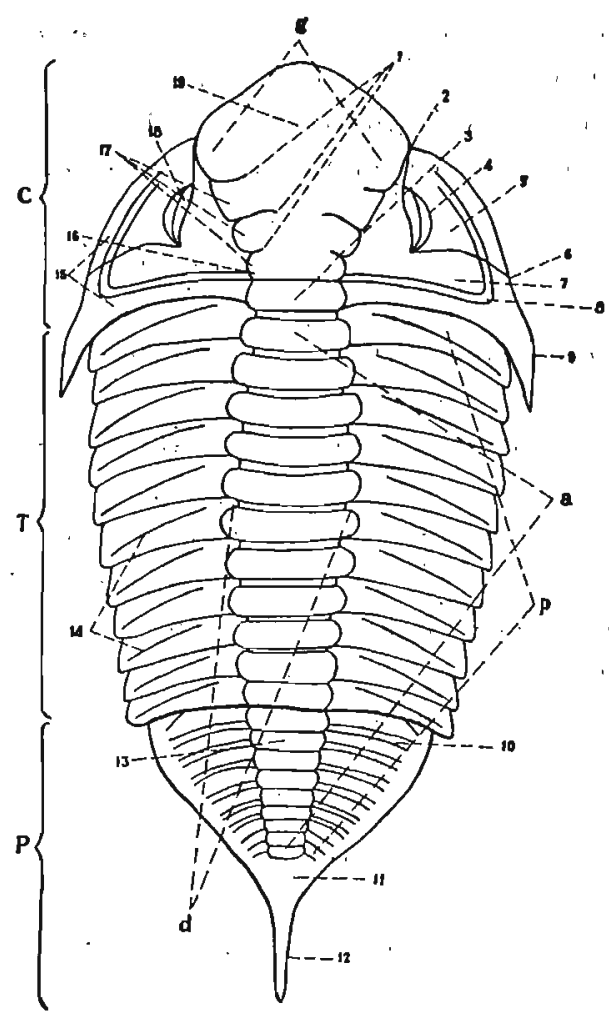
FIG. 24.- Diagrammatic figure of a trilobite. Draw-
ing after Slocon by David Tracy Jones.

Anterior: Situated in , front.

Anterior limb of the facial suture: The portion of the facial suture lying in front of the eye. (2)

Axis: The median longitudinal lobe of a trilobite. (a)

Carapace: The, hard shell covering the dorsal surface of a trilobite.

Caudal spine: A spine at the posterior extremity of the pyogidium. (12)

Cephalon: The head of a trilobite. (C)

Cheeks: The two lateral portions of the head or cephalon of a trilobite, divided into fixed (7) and free (5) cheeks by a facial suture.

Compound eyes: Eyes commonly present upon the free cheeks of trilobites; they are made up of a large number of small facets. (4)

Cranidium: The portion of the head or cephalon of a trilobite lying between the facial sutures, comprising the glabella and the fixed cheeks.

Distal: Away from the median line..

Dorsal: Pertaining to the back.

Dorsal furrows: The furrows or depressions bounding the axial or medial longitudinal lobe of a trilobite; same as the axial furrows. (d)

Doublure: The infolded margin of the trilobite test.

Facial suture: The suture in the head or cephalon of a trilobite separating the fixed from the free cheeks. $(2,6)$ 
Fixed cheek: The portion of the cephalon or head of a trilobite lying between the glabella and the facial suture. (7)

Free cheek: Lateral portion of the cephalon or head of a trilobite, lying between the facial suture and the lateral cephalic border. (5)

Frontal lobe: That portion of the glabella anterior to the first lateral furrows. (19)

Genal angles: The postero-lateral angles of the cephalon or head of a trilobite.

Genal spines: The posterior prolongation into spines of the genal angles of a trilobite. (9)

Glabella: The central or axial portion of the cephalon or head of a trilobite. ( $\mathrm{g}$ )

Holochroal eyes: Compound eyes of a trilobite whose visual area is covered with a continuous horny integument.

Hypostoma: The under lip of a trilobite.

Lateral furrows: The transverse furrows or grooves of the trilobite glabella, sometimes continuous across the glabella and sometimes greatly modified. (1) These furrows define the lobes of the glabella. (17)

Marginal border: The thickened or otherwise differentiated external border of the cephalon and pygidium of a trilobite. (15)

Marginal furrow: The groove or depression lying just within the marginal border of the cephalon and pygidium of a trilobite. (8)

Occipital furrow: The posterior transverse groove or furrow of the glabella of a trilobite, lying in front of the occipital segment. (16)

Occipital lobes: Small, lateral lobes of the occipital segment present in some trilobites, which are morphologically different from the lateral lobes of the glabella.

Occipital or neck segment: The posterior transverse segment of the trilobite glabella, lying between the posterior margin and the occipital furrow. (3)

Ocular ridges: Ridges extending from near the anterior extremity of the glabella to the eyes in some trilobites. The eye lines. 
Palpebral lobes: Lobes of the fixed cheeks within the margins of the eyes. The eye lobes. (18)

Pleurae: The two lateral longitudinal lobes of a trilobite, applied chiefly to the thoracic region and the pygidium. (p)

Pleural grooves: Grooves on the pleuræ of the thoracic segments. (14)

Pleural ribs: The fused segments in the lateral lobes of the pygidium. (10)

Post-axial region: The flattened area occupying the median portion of the pygidium of some trilobites, posterior to the elevated axis. (11)

Post-cephalic margin: The posterior margin of the head or cephalon.

Posterior cheek furrow: The marginal furrows or grooves present in some trilobites, which extend across the cheeks from the extremities of the occipital furrow of the glabella towards the genal angles. (8)

Posterior limb of facial suture: That portion of the facial suture extending from the posterior extremity of the eye to the posterior or lateral margin of the cephalon.

Proximal: Toward the median line.

Punctate: Having minute depressions or pits.

Pustulose: Covered with pustules or blister-like prominences.

Pygidium: The tail or posterior region of the trilobite test. (P)

Schizochroal eyes: Compound eyes of the trilobites in which the visual area is occupied by small openings for the separate facets.

Segments: The transverse divisions of the thorax or pygidium.

Test: The hard outer covering.of the trilobite.

Thorax: The central segmented region of the body of trilobites. ( $\mathrm{T}$ )

Ventral: Pertaining to the under surface. 


\section{TRILOBITES OF THE CAMBRIAN \\ Order HYPOPARIA Beecher \\ Family AGNOSTIDAE M'Coy}

Agnostus Parilis Hall

Plate X, figs. 10, 11.

Plate XII, fig. 1.

1863. Agnostus parilis Hall, 16th Rept. New York State Mus. Nat. Hist., p. 179, pl. 10, figs. 23, 24.

1892. Agnostus parilis Vogdes, American Geologist, vol. 9, p. 394 , pl. X, fig. 4.

Description.-Very small in size; head shield semioval in outline, truncate posteriorly, surface strongly convex curving abruptly to the sides and more gently toward the anterior margin. Margin narrow but well defined, increasing in width anteriorly. A small node is present on each postero-lateral angle. The central area of the posterior third of the shield is defined by a faint parabolic curve whose posterior extremities divide the posterior margin into three subequal parts.

The pygidium is similar in general form to the head shield. An elongate V-shaped impression extends backward on each side of the central area from the anterior margin to about one-third the length of the shield. The antero-lateral angles are obliquely truncate.

The surface of both head and tail shields is smooth.

Average length of a cephalon $3.5 \mathrm{~mm}$., width across the posterior" margin $3.2 \mathrm{~mm}$.

Position and locality.-Eau Claire formation, about one-half mile southeast of Lansing. (Field notes of T. J. Fitzpatrick.)

Remarks.-Our specimens agree quite well in general form and size with those described and figured by Hall, but differ in being proportionally shorter and in lacking the median node on each shield. These differences may be variations of minor importance or they may be the result of the mode of preservation, though both Hall's and our specimens occur in a buff or drabcolored sandstone. 


\section{Order OPISTHQPARIA}

\section{Family OLENIDAE}

\section{'Genuis 'Conaspis Hall}

Description of genus.-"Glabella subconical, medium sized eye-lobes, rather strong postero-lateral limbs, narrow.. fixed cheeks, and with facial sutures extending almost directly forward from the eye lobes so as to form a narrow frontal limb; the frontal rim is usually, well defined and cut obliquely, by the facial sutures.". (Walcott, Cambrian Geol. and Pal,,Vol. II, No.'13; p. $357,1914$.

\section{CONASPIS MICROS $\mathrm{S}$. $\mathrm{s}$. \\ Plate XI, figs. $5,6$. \\ Plate XII, fig. 2.}

Description,-Cranidium small, elongate, depressed convex, gently arched longitudinally. Facial sutures converging abruptly in front of the eye-lôbes to the dorsal furrows opposite the antero-lateral angles of the glabella, thence converging less abruptly they pass around the antero-lateral angles of the frontal limb and cut the same in line with the dorsal furrows opposite the palpebral lobes. Glabella prominent, depressed convex, subconical, gently arched longitudinally, sides straight and diverging posteriorly. Entire surface smooth., Occipital groove transverse and well defined. Occipital segment broad, flattened and strongly arched. Fixed cheeks v ery narrow within the eye-lobes, confluent with the dorsal furrows at the antero-lateral angles of the glabella; frontal limb comparatively narrow and elongate, faintly thickened near the dorsal furrow, arched transversely and sloping gently forward. The median length is somewhat greater than that of the occipital segment. Palpebral lobes narrow, elongate and bounded proximally by a fine groove. Posterior limb of fixed cheek unknown.

Free cheeks depressed and faintly sulcate about the base of the narrow orbital ridge, thence sloping abruptly to the marginal groove; border thickened and continued at the genal angles into a nearly straight spine.

Pygidium unknown... 
Dimensions.-Length of an average sized cranidium $5 \mathrm{~mm}$., width of same across palpebral lobes $4 \mathrm{~mm}$.

Position and locality.-Eau Claire formation, one-half mile southeast of Lansing (Prof. T. J. Fitzpatrick).

Remarks.-Conaspis micros occurs in association with Saratogia wisconsensis and Ptychaspis striata. Some of the thin slabs of buff-colored sandstone contain the small cranidia in great abundance. The species closely resembles Conaspis anatinus (Hall) but differs from the latter in having proportionally longer palpebral lobes and a narrower but longer frontal limb, whose sides are in direct line with the dorsal furrows.

In $C$. anatinus the frontal limb is as wide as the base of the glabella. Several curved cheek spines, more or less perfect and attached to parts of free cheeks, are associated with the cranidia. They are similar in general contour to those of Conaspis anatinus (fig. 35, Pl. VIK, 16th Ann. Rep. New York State Cab. Nat. Hist.)

\section{Family CERATOPYGIDAE}

Saratogia wisconsensis (Owen)

Plate XI, figs. 7-10.

1852. Crepicephalus? wisconsensis Owen, Rept. Geol. Survey Wisconsin, Iowa and Minnesota, pl. I, fig. 13 (illustrates a cranidium; upper figure).

1863. Conocephalites wisconsensis Hall, 16th Ann. Rept. New York State Cab. Nat. Hist., p. 164, pl. 7, figs. 39-41; pl. 8, figs. 22-24, 27, 28.

1863. Conocephalites wisconsensis Shumard, Trans. Acad. Sci. St. Louis, vol. 2, p. 103.

1863. Conocephalites latifrons Shumard, Trans. Acad. Sci. St. Louis, vol. 2, p. 101.

1867. Conocephalites wisconsensis Hall, Trans. Albany Inst., vol. 5, pp. 130, 151, pl. 2; figs. 39-41; pl. 3, figs. 23, 24, 27, 28.

1883. Conocephalites wisconsensis (Owen) Chamberlin, Geol. Wisconsin, vol. 1, p. 131.

1893. Anomocare wisconsensis Vogdes, Bibliography of Paleozoic Crustacea : California Acad. Sci., vol. IV, p. 271.

1899. Ptychoparia (Lonchocephalus) wisconsensis Walcott, U. S. Geol. Survey, Monogr. 32, pt. 2, p. 461, pl. 64, figs. 1, 1a (not $1 b$ or $1 c)$.

1916. Saratogia wisconsensis Walcott, Smithsonian Misc. Coll. 
vol. 64, No. 3, p. 198, pl. 34, figs. 5, 5a-c. Eau Claire formation (pygidium not figured).

Description.-Cranidium large, depressed convex, gently arched longitudinally. Glabella subconate, very gently rounded or nearly truncate in front, transverse behind, sides straight and diverging from front to back; surface along axial line sloping gently forward, sides sloping more abruptly from the median line to the dorsal furrows; width at the occipital groove nearly equal to the length. One pair of very faint lateral furrows originates at the dorsal furrows opposite the palpebral lobes and extends obliquely backward becoming obsolete before reaching the median region of the glabella. Occipital groove shallow but well defined at the sides, nearly obsolete in the middle. Occipital segment strongly arched, wider in the center than at the sides and bearing a long, stout and slightly arcuate median spine direeted almost horizontally backward. Fixed cheeks narrow opposite the glabella; posterior limb narrow, directed obliquely backward in such a way that a straight line projected from it would cut the anterior portion of the palpebral lobe; anterior border somewhat wider than the anterior width of the glabella, sloping downward in a gentle curve for more than one-half its width to a broad submarginal groove, thence continuing anteriorly into a flattened horizontal border. Favorably preserved specimens show flexuous lines in the submarginal furrow. The facial sutures expand -along a gentle curve from the anterior margin of the palpebral lobes to the submarginal groove then converge to the anterior border. Palpebral lobes long, crescentic, bounded proximally by a parallel groove.

Free cheek moderately convex, surface sloping in a curve from the eye to the marginal groove; border thickened and continued into a long, slender, inwardly curved spine at the genal angles and a very short spine in front.

Pygidium transversely subelliptical, anterior margin describing the arc of a great circle, posterior margin the arc of a smaller circle, slightly emarginate posteriorly; antero-lateral angles obtusely rounded. Length is to width as 1 to 2.5. The outer margin is somewhat thickened, nearly horizontal, decreasing in width posteriorly. The axis is very prominent, conical, rising abruptly 
above the 'pleuræ, occupying one-fourth' the anterior width of the shield; sides straight and tapering uniformly to a raised obtusely rounded termination within the marginal groove. A rounded, abruptly tapering ridge connects the last segment with the posterior margin. There are five rounded transverse segments the first four of which decrease regularly in size, the fifth or terminal segment being about twice as wide as the fourth. The pleural lobes slope gently and evenly from the dorsal furrows to the marginal grooves. There are three broad, flattened annulations exclusive of the anterior articulating ring; all end at the marginal groove. The anterior annulation is faintly sulcate, the sulcus originating on the posterior margin at the dorsal furrow, passing obliquely forward to the center of the annulation and thence outward medially to the end.

There is a wide range in size of both cranidia and pygidia. An average sized cranidium of the specimens at hand is $13.5 \mathrm{~mm}$. long exclusive of the occipital spine, $10.2 \mathrm{~mm}$. wide across the palpebral lobes, and $11 \mathrm{~mm}$. wide across the frontal border. The median length of a large specimen, exclusive of occipital spine, is $27 \mathrm{~mm}$. A pygidium of average size is $10.5 \mathrm{~mm}$ long and 23.5 mm. wide.

Position and locality.-.Upper Cambrian, Eau Claire formation, Lansing, Iowa. Prof. T. J. Fitzpatrick collected the specimens about half a mile down the river from the town.

...Remarks.-The specimens upon which the foregoing description is based were collected from approximately the same position and locality in Iowa as that given by Walcott (op. cit., p. 199) for this species. Figure 11, Plate XI, is a good illustration of the associated fauna. The pygidium is referred to this species only tentatively, none having thus far been found in actual conjunction with the thorax and cephalon. Two types of pygidia are associated on the slabs from this locality. The larger type has a definite, somewhat thickened, and moderately wide horizontal border and agrees well in size with $S$. wisconsensis. The second type because of its smaller size and other differences discussed under that species is referred to:Ptychaspis striata. 
Family · ILLEENIBAE Corda:

Genús Tritaenurướs Háll

LluaEnurus quadratus Hall

1863.. Illaenurus quadratus Hall, 16th Rept. New Y̧ork State Mus. Nat. Hist., p. 176, pl. 7, figs. 52-57.

1916. Illaenurus quadratus Walcott, Smithsonian Misc. Coll, vol. 64, No.'5, p. 406, pl. 45, figs. 1, Ia-e. Walcott points out that the thorax has eleveri segments.

That this species has been found in the Upper Cambrian of Iowa is somewhat doubtful. Associated with Illaenurus calvini there is but one incomplete cranidium which in any degree resemblés I. quadratus. The latter differs from the former in having a proportionally shorter and wider cranidium, diverging less anteriorly, and in having eleven instead of ten thoracic segments.

Further field work in the Upper Cambrian of Iowa will undoubtedly prove its"presence here sinee it is reported from similar formations in 'Wisconsin and Minnesota.

$$
\begin{aligned}
& \text { ILIAENURUS CaLviNI n. } \mathrm{s} \text {. } \\
& \text { Plate XI, figs. 15-20. }
\end{aligned}
$$

1921. Illaenurus calvini Walter, Up. Camb. Trilobites: . Abstr. Bull. Geol. Soc. Am., vol. 32, p. 128 (brief notice).

Description.-Body broad, oval-elongate, anterior and posterior margins broadly rounded, sides very gently rounded. Trilobation distinct. Length is to width as 8 to 5 . Cephalon large; nearly semicircular on outline; twice as wide as it is long; genal angles rounded. Glabella undefined. Cranidium large, flattened and smooth, the part in front of the palpebral lobes being keystone shaped and somewhat longer than one-half the total length. Occipital segment narrow, faintly but clearly defined between the indistinct dorsal furrows along the articulating margin. Dorsal furrows undefined. Palpebral lobes marginal, crescentic and located slightly posterior to the middle of the cranidium. The width across the palpebral lobes is approximately equal to the width across the anterior extremity... Fixed cheeks extended posteriorly into long, narrow, flattened limbs, ending a short distance within the genal angles. 
Free cheeks large, subtriangular, very gently convex, somewhat longer than wide, and continuous with the antero-lateral margin of the glabella. Genal angles rounded and faintly produced.

The facial sutures originate on the posterior margin of the cephalon just within the genal angles and describe a slightly sinuous curve to the posterior margin of the palpebral lobes in front of which they diverge toward the anterior margin, cutting the same approximately in line with the outer margin of the eye lobes.

Thorax subquadrate, nearly as wide as it is long, subequally trilobate, composed of ten segments; sides gently rounded: Axis broad, occupying one-half the width of the thorax, separated from the pleural lobes by broad shallow dorsal furrows. Pleural lobes narrow, having a serrate outer margin due to the slightly recurved tips of the segments. A shallow groove extends diagonally across each segment from the inner anterior to the outer posterior margin. The segments are longest and widest in the center, decreasing in size toward the anterior and posterior ends.

The pygidium is flattened, much smaller than the cephalon and transversely biconvex in outline. The anterior margin describes the arc of a large circle, the posterior margin that of a smaller circle. An axis is faintly visible.

Dimensions.-No. 9002 , length of cranidium $13 \mathrm{~mm}$., width of same across palpebral lobes $9.7 \mathrm{~mm}$.; No. 9000, length of thorax $11.4 \mathrm{~mm}$., width of same $13.6 \mathrm{~mm}$. Length of pygidium $5 \mathrm{~mm}$.

Position and looality.-Upper Cambrian, St. Lawrence limestone, on Fire-bell Hill, Lansing.

Remarks.-Most of the material upon which the description of this species is based was collected nearly thirty years ago by the late Dr. Samuel Calvin. In the Iowa Geological Survey, volume IV, page 58 , Professor Calvin calls attention to these specimens in the following words: "There are occasional fragments of an Illaenurus, differing from Illaenurus quadratus $\mathrm{Hall}$, in the form and other characters of the glabella: In general the trilobites are represented only by impressions of dismembered portions of the dorsal exoskeleton, but in two specimens of Illaenurus the gla- 
bella and thoracic segments retain their normal, relative position."

The species occurs in association with $D$. minnesotensis and Aglaspis thomasi. Cranidia, free cheeks and pygidia are found rather commonly. Entire specimens are exceedingly rare.

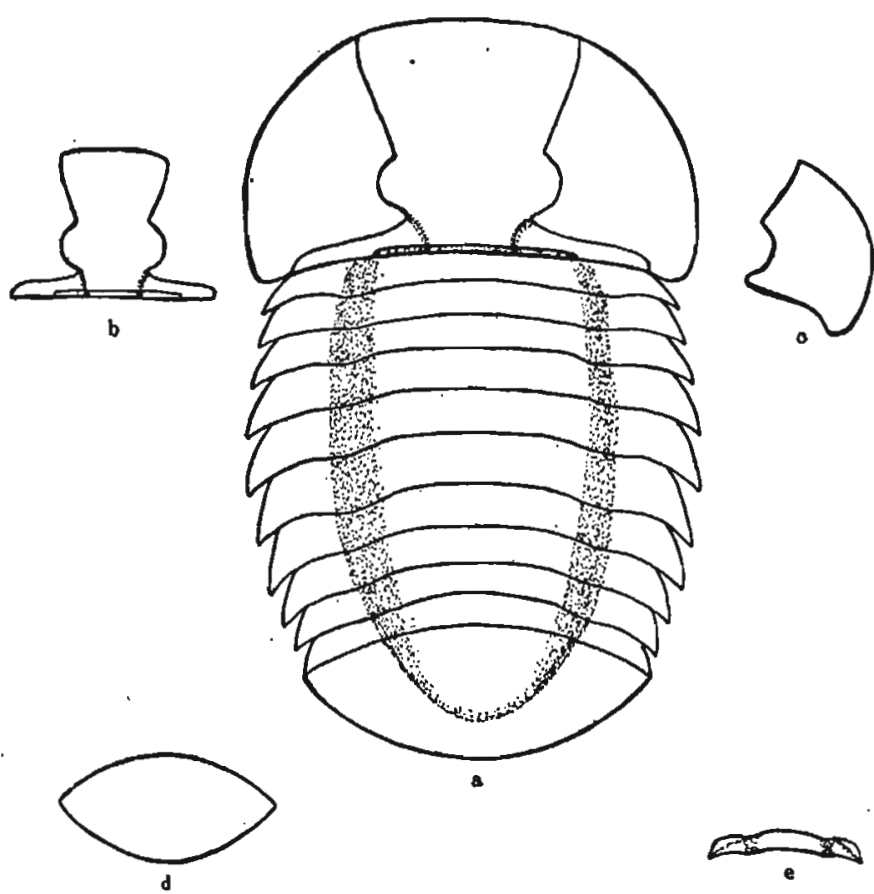

FIG. 25.-Restoration of Mllaenurus calvini; a, complete specimen much enlarged; b, cranidium, note narxow occipital segment; c, free cheok, very broad with rounded genal angle; d, outline of a nearly featureless pygidium; $\theta$, thoracic segment.

Illaenurus calvini differs from I. quadratus in having a proportionally longer cranidium, a greater divergence in front of the eye-lobes, in being narrower between the proximal ends of the posterior limbs of the fixed cheeks, in having ten instead of eleven thoracic segments, and in the presence of long postero-lateral extensions of the fixed cheeks.

The species is named in honor of the late Professor Calvin.

Figure 25 is a restoration of the species. 


\title{
Family. DIKELOCEPHALIDAE \\ Dikllocephalus minnesotensis Owen
}

\author{
Plate X, figs. 1-9.
}

1852. D. minnesotensis Owen, Rep. Geol. Surv. Wisconsin, Iowa and Minnesota, p. 574, pl. 1, figs. 1, 2 ; pl. 1 A, figs. 3, 6.

1914. D. minnesotensis Walcott, Cambrian Geol. and Pal., Smithsonian Miscellaneous Collections, vol. 57, No. 13, p. 369 ; pl. 60 , figs. $1-8$; pl. 61 , figs. $1-3,5-7$; pl. 62 , figs. 4-6; pl. 66 , fig. 1.

The body form, as restored by Owen, 1852, is subquadrate, the sides are subparallel, the posterior margin is broken by the presence of two postero-lateral caudal spines. Body depressed away from the central axis. .

The head is broadly crescentic in outline, the long genal spines forming the horns of the crescent. The even concave posterior margin is interrupted centrally by the recurved upward arching of the occipital ring.

The cranidium is roughly four sided, being narrowest about its midlength, wider across the palpebral lobes and frontal shield, and widest across the posterior limbs of the fixed cheeks.

The glabella is quadrangular, longer than wide, moderately to strongly convex, evenly rounded in front, less rounded in back, sides parallel. It is divided by the two furrows traversing it into one large well-rounded anterior and two narrow posterior lobes. The occipital furrow is moderately impressed and almost straight. The posterior glabellar furrow is more deeply impressed; it arises near the midlength of the marginal border and curves backward to the middle line where it is separated from the occipital furrow by a distance equal to the width of the occipital ring, thus forming a middle lobe which is laterally expanded. The anterior lobe is well rounded in all directions and partly divided on each side by $a_{1}$ submedian sidefurrow which extends about one-third the distance across, Very rarely another even fainter side furrow may be observed anterior to the last.

The facial suture is sigmoid, arising at the lateral margin of the frontal shield in line with or somewhat in front of the anterior extremity of the glabella; it proceeds along a slightly curved line to the narrowest part of the fixed cheek and is continued around 
the palpebral lobe, thence abruptly outward along the posterior limb of the fixed cheek, ending at a distance from the dorsal furrow equal to the average width of the glabella.

The fixed cheeks are extended in front of the glabella into a broad slightly arched and rounded frontal shield. Thus the cephalon has the form of an inverted shovel with a broad shallow groove crossing it near the posterior margin parallel to the free edge. The cheeks are most constricted a little in front of the palpebral lobe, thence they spread out opposite the occipital furrow and extend laterally as narrow, flattened, knife-blade-like posterior limbs bearing a deep submarginal furrow which is continued into the free cheek.

The free cheek is subtriangular in shape and extends posteriorly into a long flattened spine. The even contour of the posterior margin is broken by the posterior limb of the fixed cheek. The posterior half of the inner margin gives rise to a deep sinus for the eye. The anterior half is curved in accordance with the outer margin of the frontal shield, in front of which it is continued as a spine. The outer margin is of even contour, having a faint submarginal depression. The area around the sinus is convex, sloping abruptly toward the flattened outer area.

The hypostoma is broad, the central portion is oval-elongate to subcircular, the margins are expanded, bearing à submarginal groove which ends in a pit on each side of the central portion near the posterior end.

The thorax is subquadrate, axis convex and narrow, pleural lobes depressed, sides subparallel, dorsal and intersegmental furrows well defined.

Thoracic segments composed of well arched axial rings onefifth the width of the thorax and continued in front as a narrow similarly arched elliptical plate. They are continued obliquely outward and backward as pleural segments which are raised and narrow near the axis, but wider where they flatten out distally until they end in recurved sword-shaped tips. An intrasegmental furrow of diminishing proportions begins at the inner anterior margin and extends diagonally across to the outer posterior margin. This same character is continued into the pygidium, be- 
coming less recognizable toward the extreme posterior end of the axis.

The pygidium is transverse, wider than long by a length usually equal to or greater than that of its axis. Axis strongly arched throughout, composed of five segments including the large terminal segment, which often shows faint transverse furrows across its anterior half. The pleural lobes are convex near the axis, sloping down into a flattened area to the margin. The sides are gently rounded, produced into a spine at the postero-lateral angle and have a broadly rounded posterior margin between the spines. The lateral lobes are marked by five divided segments whose furrows are confluent distally with the flattened margin. The intrasegmental furrows begin at the inner anterior margin and after curving abruptly to the middle continue centrally along the downward slope. Posteriorly the furrows are so faint that they are hardly distinguishable. The surface is marked by fine concentric inosculating lines.

Dimensions.-Specimen No. 9017, a cranidium, median length $36 \mathrm{~mm}$. ; width across palpebral lobes $41 \mathrm{~mm}$. ; width between the extremities of the posterior limbs of the fixed cheeks $63 \mathrm{~mm}$.; length of glabella $29 \mathrm{~mm}$. Number 9016, a pygidium, median length $35 \mathrm{~mm}$.; greatest width $62 \mathrm{~mm}$.; length of axis $28 \mathrm{~mm}$.

Horizon and locality.-Nearly all of the material of this species now in the University collection comes from the St. Lawrence limestone on Fire-bell Hill, Lansing. There is another exposure at the same horizon three miles west of Lansing on a hillside north of the road and about twenty feet above it. Here slabs were found which contained the impressions of a number of thoracic: segmients.

Remarks.-Most of the material is preserved in a greatly depressed and flattened state. This has a tendency to distort the natural proportions, especially those of the glabella, which is usually wider across the middle lobe than it should be. In an unusually well preserved cranidium, No. 9005, from Baraboo, Wisconsin, the transverse and longitudinal convexity is well shown and the sides of the glabella are parallel. This genus contains some of the largest species of the Dikelocephalinæ, the giants of Cambrian trilobites. The University collection contains a frag- 
mentary pygidium, No. 9262, which if fully restored would have a width of $22 \mathrm{cms}$.

\section{Ptychaspis striata Whitfield}

Plate XI, figs. 11-14. Plate XII, figs. 3, 4.

1863. Ptychaspis granulosa Hall, 16th Rept. New York State Cab. Nat. Hist., p. 173, pl. 6, figs. 33, 37, 38, not Ptychaspis granulosa (Owen).

1878. Ptychaspis striata Whitfield, Ann. Rept. Geol. Surv. Wisconsin, p. 55.

1880. Ptychaspis striata Whitfield, Ann. Rept. Geol. Surv. Wisconsin, 1879 , p. 5.1 .

1882. Ptychaspis striata Whitfield, Geology of Wisconsin, vol. IV., p. 186.

Description.-Cranidium subtrapezoidal in outline; anterior border narrow, thickened slightly, broadly rounded and deflected almost 80 degrees from horizontal; facial sutures faintly subangular, extending in a straight line from the postero-lateral angles to the eyes, thence more directly forward, rounding the antero-lateral angles in a broad curve. Glabella prominent, subsemicylindrical, longer than wide, rising strongly above the dorsal furrows and cheeks, sides straight and parallel, anterior margin broadly rounded. The anterior glabellar lobe is globose, occupying more than one-third the glabella. Two pairs of lateral furrows cross the glabella; the first pair curves gently backward from the dorsal furrows, becoming shallower over the median area; the second pair is stronger and directed more obliquely backward at the sides. The occipital groove is straight, shallow medially, deeper at the sides, becoming much larger as it continues along the posterior margin of the fixed cheeks. Occipital segment strongly arched, equaling in width the median glabellar lobes.

Fixed cheeks large, depressed convex transversely, rising abruptly from the anterior border to the palpebral lobes and increasing in width to the posterior margin. Palpebral lobes very small and situated opposite the anterior lateral glabellar furrows. The anterior two-thirds of the cranidium is marked by strong wavy striæ roughly parallel to the margin. 
Free cheeks strongly convex, sides sloping abruptly to a deep marginal groove, which becomes shallower anteriorly and does not communicate with the posterior marginal groove at the genal angles. Border greatly thickened and marked by several conspicuous striæ produced posteriorly into a strong spine. 'The surface of the cheeks from the eye toward the marginal groove is marked by striæ similar to those found on the cranidium.

Pygidium transversely elliptical, anterior margin describing the arc of a large circle, posterior margin that of a much smaller circle, the two ares meeting at the sharp antero-lateral angles. Border slightly thickened and narrow throughout. Axis prominent, semiconical, tapering gradually to a raised obtusely rounded termination well within the margin. Segments four, all well defined by deep intersegmental grooves. The pleural lobes are narrowly depressed near the axis, thence slope strongly to the marginal furrow; each is marked by three flattened annulations, which bear a distinct median sulcus throughout their entire length.

Dimensions.-Number 9234 , length of cranidium $8.5 \mathrm{~mm}$., greatest width of same $14.2 \mathrm{~mm}$. Specimen 9235 , length of pygidium $8.5 \mathrm{~mm}$, width of same $18.5 \mathrm{~mm}$.

Position and locality.-Upper Cambrian, Eau Claire formation, one-half mile southeast of Lansing (Prof. T. J. Fitzpatrick).

This species is associated with Saratogia wisconsensis in thin slabs of fine-grained buff-colored sandstone. It is about equally abundant with the latter. The pygidium is referred to this species with doubt. From $S$. wisconsensis it differs in having but four instead of five axial segments, a very narrow marginal border, more abruptly sloping pleural lobes and all the annulations distinctly sulcate.

$$
\begin{gathered}
\text { Saukia PYREne Walcott } \\
\text { Plate X, figs. 12, } 13 .
\end{gathered}
$$

1914. Saukia pyrene Walcott, Cambrian Geology and Paleontology, vol. II, No. 13, p: 382, pl. 67, figs. 18-29.

Description.-Cranidium subquadrate; anterior margin thickened, broadly rounded and set off from the glabella by a narrow 
but deep submarginal furrow; posterior margin transverse; dorsal furrow well defined. Glabella subquadrate, widest opposite the posterior part of the palpebral lobes, narrowing in the region of the second and third glabellar furrows, thence widening toward the anterior end. Occipital segment transverse, moderately arched; occipital furrow well defined and curved slightly forward; first glabellar furrow also well defined but not as prominent as the occipital furrow; curved slightly backward; second glabellar furrow very faint, subparallel to first and continued entirely across; third glabellar furrow represented on each side by a short, faint, forwardly directed furrow which is equidistant from the anterior glabellar margin and the second furrow.

Palpebral lobes prominent, about half as long as the glabella, bearing a strong intermarginal furrow which is directed inward, meeting the dorsal furrow opposite the third glabellar furrow.

Remarks.-As far as known this is the first record of this genus in Iowa. It must be considered a very rare fossil because a continued three day search on the part of Doctor Thomas and the writer in the Dikelocephalus layer of the St. Lawrence limestone at Lansing revealed only this one fragmentary cranidium. It is likely, however, that it is present in the collections of others who have collected from time to time in this same locality, but its rather small size and scarcity as well as its surficial resemblance to D. minnesotensis may have caused it to be overlooked. It is hoped that eventually better specimens will be found. This cranidium is similar in most respects to Saukia pyrene Walcott 1914 but there are several minor differences: the anterior margin of the cranidium is somewhat wider and thicker, the glabella is relatively shorter and wider and the second or middle glabellar furrow extends entirely across.

Dimensions.-Length of cranidium $8 \mathrm{~mm}$., length of glabella $5.5 \mathrm{~mm}$., greatest width of glabella $4.6 \mathrm{~mm}$.

This species is associated with Dikelocephalus minnesotensis and Illaenurus calvini. 


\section{ARACHNIDA OF THE CAMBRIAN \\ Class ARACHNIDA \\ Subclass Merostomata Woodward \\ Order SYNXIPHOSURA Packard \\ Family AGLASPIDAE Walcott \\ Aglaspis thomasr Walter \\ Plate XI, figs. 1-4.}

1924. Eurypterus thomasi Walter, Iowa Acad. Sci., Proc., vol. XXIX, pp. 127, 128.

Description.-The carapace is subcircular in outline, anterior margin well rounded, posterior margin broadly concave, sides diverging gently posteriorly and somewhat produced at the postero-lateral angles. The outer edge bears a faint submarginal groove which is wider and more shallow from front to back. The compound eyes are prominent, reniform, situated approximately in the middle and as far apart as the distance of each is from the lateral margin. Their greatest length is two millimeters. A shallow groove beginning at a point nearly midway between the eyes and the posterior margin extends to the postero-lateral angles. The entire surface, as preserved, is flattened and smooth. Length $8 \mathrm{~mm}$., width across postero-lateral angles $13 \mathrm{~mm}$.

An impression of the under side of a fragmentary tergite of the Aglaspid type occurs in the same layers of limestone in which the carapace was found. This specimen is flattened, its anterior and posterior margins are subparallel and entire, describing a broad sigmoid curve; the outer antero-lateral angle is rounded and the postero-lateral angle is produced into a short spine. A low rounded ridge begins proximally about midlength and extends outward and slightly backward, becoming obsolete some distance before reaching the outer margin. The obverse of this ridge very likely represents the groove which limits the posterior margin of the overlapping tergite. The entire surface is crowded with minute porelike pits which open obliquely on the surface. They are smallest and most numerous over the low ridge and largest along the posterior half of the proximal end. A narrow zone along the anterior margin is entirely smooth. 
Position and locality.-Upper Cambrian, St. Lawrence limestone, on "Fire-bell Hill," Lansing. Collected by the writer. Museum numbers, 9008, 9009.

Remarks.-Aglaspis thomasi occurs in association with the dismembered parts of Dikelocephalus minnesotensis and Illaenurus calvini. It is of special interest because it represents the first species of this genus ever recorded from the Cambrian of Iowa. In general outline of cephalothorax it resembles $A$. eatoni Whitf. but differs from the latter in having the eyes more centrally located and in possessing apparently no nodes either on the posterior margin of the cephalic shield or on the abdominal segments.

The writer is greatly indebted to Dr. C. D. Walcott for the generic classification of $A$. thomasi. The species is named in honor of Dr. A. O. Thomas.

\section{TRILOBITES OF THE ORDOVICIAN}

Order HYPOPARIA Beecher Family HARPEDIDAE Barrande

Genus Harpes Goldfuss

Sub-genus EoHarpes Raymond

Eoharpes cf. E. ottawaensis (Billings)

Plate XIII, figs. 1, 2.

1865. Harpes ottawaensis Billings, Paleozoic Fossils Canada, vol. I, p. 183, fig. 166.

1897. Harpina, cf. H. ottawaensis Billings (sp.), Clarke, Pal. Minnesota, vol. 3, pt. 2, p. 757, fig. 79.

1902. Harpina ottawaensis Weller, Pal. New Jersey, vol. III, p. 191, pl. 14, figs. 1, 2.

1909. Eoharpes ottawaensis Bassler, Bull. Virginia Geol. Surv. 29, p. 111, fig. 10.

1910. Eoharpes ottawaensis Raymond, 7th Rept. Vermont State Geol., p. 215, pl. 32, fig. 2.

Description.-border of the cephalon including the genal spines horseshoe-shaped in outline. The spines converge gently throughout most of their length but curve strongly inward at their extremities. The brim is widest anteriorly, narrowing uniformly posteriorly; the outer and inner margins are slightly 
thickened and smooth but the area between is thickly pitted. A single row of larger pits extends around the outer and inner margins respectively, each being just within the smooth zone.

Specimen 9205, comprising the border and genal spines, is 32 $\mathrm{mm}$. long and $26 \mathrm{~mm}$. wide. The breadth of the brim at the anterior end is $5 \mathrm{~mm}$.

Position and localities.-Platteville limestone, Boyle's quarry, McGregor (Mr. A. G. Becker). Platteville limestone, Dubuque, about three hundred yards upstream from the high bridge and six to eight feet above low water mark of Mississippi river.

This very interesting trilobite, though recorded from Minnesota, had not been found in Iowa until the summer of 1921 when Mr. Becker found two specimens near McGregor. The larger of these has been described above. After seeing Mr. Becker's specimens it was the good fortune of the writer to find one specimen at Dubuque which is, however, less perfectly preserved than either of the other two. It is hoped that more material will be found which will show not only the cephalic border but the entire body so that there may be no doubt concerning the identity of the species. The material at hand agrees strikingly well with the specimen figured by Raymond (op. cit., 1910).

\section{Family BATHYURIDAE}

Bathyurus spinigrr (Hall)

$$
\text { Plate XIII, figs. 6, } 7 .
$$

1847. Acidaspis spiniger Hall, Pal. New York, 1, p. 241, pl. 64, fig. 5.

1884. Bathyurus spiniger Clarke, Geol. Minnesota 3, pt. 2, p. 723 , figs. 38-40.

1910. Bathyurus spiniger Raymond, Ann. Carnegie Mus., 7, p. 48, pl. 15, figs. 4-6.

This species is represented in the University collection by an incomplete partly exfoliated cranidium, No. 9188, from the Platteville limestone along Sny Magill creek, Clayton county. The anterior border is broadly rounded in outline, moderately wide, gently concave and slightly thickened at the edge. The glabella is oval-elongate and strongly convex transversely; its anterior 
margin extends to the concave border and is sharply rounded, the sides are very gently convex, the base is transverse and separated from the occipital segment by a prominent smooth groove. The surface of the glabella is tuberculate, the tubercles of the anterior half being smaller and more numerous than those of the posterior half. Two pairs of shallow glabellar furrows are discernible by the absence of tubercles on them. The first pair originates at the dorsal furrows about midlength of the glabella and is direeted obliquely inward for a short distance; the second pair originates approximately opposite the palpebral lobes and extends parallel to the first pair for a short distance, whence it turns abruptly backwards but does not open into the occipital groove. The length of the glabella is $12 \mathrm{~mm}$.

Associated in the same formation with this species is a hypostoma of a Bathyurus, No. 9186, which is here provisionally referred to $B$. spiniger.

Position and locality.-Specimens Nos. 9186 and 9188 were eollected by Professor Thomas and the writer in the Platteville limestone on Sny Magill creek, Clayton county.

\section{Family ASAPHIDAE}

ECtenaspis beckeri (Slocom)

Plate XIII, figs. 8, 9. Plate XXVII, fig. 22.

1913. Megalaspis beckeri Slocom, New Trilobites From The Maquoketa Beds of Fayette County, Iowa: Field Museum of Natural Hist., Publication 171, vol. IV, No. 3, p. 50, pl. XIV, fig. 5.

1916. Megalaspis beckeri Slocom, Iowa Geol. Survey, vol. XXV, p. 196, pl. XV, fig. 5.

1920. Ectenaspis beckeri Raymond, Bull. Mus. Comp. Zool., vol. LXIV, No. 2, p. 292.

Description.-General form subelliptical in outline; sides broadly rounded and steeply sloping; head produced into a long, pointed and slightly upturned process. Pygidium narrowly rounded. Trilobation distinet-on the thorax, less distinct on the pygidium. The length is nearly 2.4 times the greatest width.

The eephalon is subtriangular elongate; posterior and lateral margins gently incurved. The sides are compressed and nearly 
vertical. The occipital region is gently convex between nearly obsolescent dorsal furrows. The glabella is defined from the rest of the dorsal surface by its somewhat greater convexity. In front of this the surface is depressed and continued into an elongate, pointed and slightly upturned process. The palpebral lobes are prominent and extend obliquely inward as broadly rounded ridges which gradually diminish in size until lost in the convexity of the glabella. The occipital furrow is wanting in the central area; laterally it is present as a broad shallow groove which extends well into the free cheelss.

The facial sutures originate on the posterior margin on a level with the fulcrum, converging slightly to the eyes; in front of the eyes they converge more abruptly to the anterior extremity.

The eyes are not preserved but probably they reached a height considerably above that of the glabella.

The free cheeks are very elongate subtriangular in outline, forming the sides of the head; they are widest opposite the occipital region, becoming gradually narrower toward the anterior extremity; posteriorly they are continued into genal spines which extend to the sixth thoracic segment.

Thorax subquadrate, sides gently rounded, trapezoidal transversely, moderately trilobate and composed of eight segments. The width is to the length about as 3.5 to 2 . The axis is low and broadly rounded, occupying more than one-third the width of the. thorax. It is bounded laterally by shallow subparallel dorsal furrows which approach each other along gentle outward curves from front to back. The segments are smooth and flat and of uniform breadth throughout. The intersegmental grooves are narrow and shallow. Pleuræ flattened for one'half their width, thence abruptly deflected to the margin: Each segment bears a strong sulcus which begins proximally on the anterior margin, thence passes diagonally outward over the fulcrum, becoming obsolete upon the sides. Distally the segments are flattened and strongly imbricated, each bearing a "Panderian organ" near the anterior margin midway between the fulcrum and the outer edge.

Pygidium subtriangular in outline; sides nearly straight, produced posteriorly into a narrow, obtusely rounded extremity. Axis low and broadly rounded, tapering at first strongly then 
very gradually to an obtusely rounded extremity well within the margin. The pleuræ curve abruptly to the nearly vertical lateral margin. Eight obsolescent annulations may be counted upon the surface from which the crust has been removed. A strong furrow is present posterior to the articulating ring. The length is to the width as five is to six. The surface is covered with fine pustules.

Dimensions of the type specimen.-Length of body $88.5 \mathrm{~mm}$., length of cephalon $42 \mathrm{~mm}$., length of thorax $22 \mathrm{~mm}$., length of pygidium $25.2 \mathrm{~mm}$.

Position and locality.-Lower Maquoketa, Elgin beds, Clermont and Postville Junction (Slocom).

Remarks.-The specimen above described is the type which has been so well described by Slocom and named in honor of the finder, Mr. A. G. Becker, whose kindness made it possible for the writer to study and figure this very valuable and unique form. That the species is exceedingly rare is evidenced by the fact that repeated visits to the type locality by Mr. Becker as well as an intensive search by Doctor Thomas for more material have been unsuccessful. Therefore the type specimen in possession of Mr. Becker and the "nearly complete cranidium" found by Slocom in the Lower Maquoketa beds at Postville Junction represent nearly all the known material of this species to date. The statement by Raymond (op. cit., p. 293), that there were two specimens of the trilobite on the same slab of limestone could not be verified.

While collecting in the Platteville limestone near Eagle Point, Dubuque, the writer found an incomplete pygidium, No. 9185, which appears to belong to this species and which is much larger than that of the holotype. It preserves well the specific characters and has the concave marginal border strongly produced posteriorly.

\section{Vogdesta vigilans (Meek and Worthen) Plate XVI, figs. 1-5.}

1875. Asaphus vigilans M. \& W., Geol. Surv. Tllinois, vol. VI, p. 497, pl. 23, fig. 6. From Carroll county, near Mount Carroll, and near Oswego, in Kendall county, Illinois, in the Cincinnati shales of the Lower Silurian. 
1887. Illaenus (Nileus) minnesotensis Foerste, Fifteenth Rep. Geol. and Nat. Hist. Surv. Minnesota, p. 478, fig. 1.

1897. Nileus vigilans Clarke, Pal. Minnesota, III, pt. 2. p. 712, figs. 17-19. From Lower Trenton (Black River), Minneapolis; Galena shales, Wylroff, Pleasant Grove, Minn.

1904. Nileus vigilans G. E. Finch, Notes on the Position of the Individuals in a Group of Nileus vigilans Found at Elgin, Iowa: Proc. Iowa Acad. Sci., 1903, vol. XI, p. 179.

1910. Vogdesia vigilans Raymond, Notes on Ordovician Trilobites, Ann. Carnegie Mus., vol. 7, No. 1, p. 70.

1913. Nileus vigilans Slocom, New Trilobites from the Maquoketa Beds of Fayette County, Iowa: Field Museum Nat. Hist., Publication 171, Geol. Series, vol. IV, no. 3.

1916. Nileus vigilans Slocom, Trilobites From The Maquoketa Beds of Fayette County, Iowa:" Iowa Geol. Surv., vol. XXV, p. 199, pl. 15, figs. 9-15.

1920. Nileus (Vogdesia) vigilans Raymond, The Appendages, Anatomy and Relationships of Trilobites: Mem. Conn. Acad. Arts Sci., vol. VII, p. 102, Dec., 1920.

"Body convex, trilobation very obscure, subelliptical in outline, lateral margins nearly parallel. Surface smooth to the naked eye, but under a magnifier the extremities are seen to be ornamented with transverse impressed lines. These lines are most distinct on the doublure and anterior portion of the glabella and rather indistinct on the pygidium. Free cheeks finely punctate.

Cephalon sublunate in outline, somewhat depressed on the anterolateral margin, convex, frontal slope inflated but not projecting. Margin marked by a slight recurved elevation; genal angles obtusely rounded; free cheeks large, produced in front of the cranidium nearly or quite to the median line. Eyes small for the genus but prominent, situated at points each one-third the transverse diameter of the cephalon, and about their own diameter from the posterior margin. The facial sutures originate on the posterior margin of the cephalon at about one-third the distance from the dorsal furrows to the genal angles, curve obliquely forward over the palpebral lobes, thence in sigmoid curves to the anterior margin, where they meet. Glabellar furrows, dorsal furrows and occipital ring and furrow are obsolete on the surface of the test, but on casts the location of the dorsal furrows is indicated on each side by pits at the posterior margin of the cephalon. These pits are connected by a shallow occipital furrow which runs parallel to the posterior margin until near the median point, where it arches forward.

Thorax composed of eight broad, flat segments, trilobation very 
obscure ; axis about three-fourths the entire width, depressed convex; pleural lobes curving regularly to the lateral margins; segments arched slightly forward on the axial lobe, somewhat curved backward. On enrolled specimens this backward curve appears greater than it really is on account of the flattening of the anterior portion of the pleuræ, which originates at the dorsal furrows and gradually widens distally. On the anterior border at the dorsal furrow of each segment are small projections which point forward and fit into corresponding notches of the preceding segment. The segments are without grooves on the test, but on the casts a shallow groove connects the dorsal furrows.

Pygidium somewhat narrower but longer than the cephalon, depressed convex, sloping equally to the margins, trilobation and segmentation wanting on the surface of the test but faintly discernible on the casts.

Remarks.- The Maquoketa specimens, above described, appear to correspond in practically all points to the orginal description and are from a similar horizon to the type. The Galena. and Trenton specimens referred to this species and described by Clarke appear to differ as follows: The facial sutures reach the margin of the cephalon in front of the eyes, while in the Maquoketa specimens the sutures reach the anterior margin near the median line of the cephalon. The front part of the cranidium is more inflated in the Maquoleta specimens.

Locality and horizon.-This species was described originally from the Cincinnati shales of Carroll and Kendall counties, Illinois. It has been collected by the writer from the Lower Maquoketa beds at Clemiont, Elgin, and Bloomfield, and from the Upper Maquoketa bed at Pattersons Springs near Brainard.'

This interesting species, which has been so adequately described by Slocom and whose life habits have been discussed by Finch and by Raymond, is one of the beautiful and fairly common forms of the Maquoketa beds of northeastern Iowa. Members of this rather gregarious and usually well preserved species are commonly found enrolled but in the slab of limestone found by Mr. G. E. Finch and containing fifteen specimens the majority were straight or nearly so.

In the University collection there are twenty complete or nearly complete specimens and numerous free cheeks, cranidia and pygidia. The following localities are represented: No. 9135, Lower Maquoketa, Dover Mills; No. 9250, Clermont; No. 9252, northwest quarter of section 11, Springfield township; Winneshiek county; No. 9253, Upper Maquoketa, section 19, Clermont. township, Fayette county; No. 9190, Lower Maquoketa, Elgin. 


\section{VogDesia GIGas Raymond \\ Plate $\dot{X} V$, Figs. 4, 5 .}

1920. Vogdesia gigas Raymond, Bull. Mus. Comp. Zool., Ḧarvard College, vol. LXIV, No. 2, p. 292, July, 1920.

"This species differs from $V$. vigilans only in that the type is twice as large as the largest known specimen of the latter, the eyes are farther from the anterior margin, and the test is slightly if at all punctate.

Measurements.-Specimen, if extended, about $120 \mathrm{~mm}$. long. The cephalon is $34 \mathrm{~mm}$. long and $58 \mathrm{~mm}$. wide; the eye is $8 \mathrm{~mm}$. long and $8 \mathrm{~mm}$. from the posterior margin. The pygidium is 36 $\mathrm{mm}$. long and $55 \mathrm{~mm}$. wide, with no trace of an axial lobe. The thorax is estimated to be about $50 \mathrm{~mm}$. long, each of the eight segments being $7 \mathrm{~mm}$. wide in the enrolled state.

Horizon and locality.-This species is known from a single specimen collected by the writer near the base of the Maquoketa on a creek four miles west of Clermont, Iowa. Holotype, M. C. Z. 1,589.' After Raymond. 1920.

Remarks.-No complete specimens of $V$. gigas have been observed by the writer but.Doctor Thomas collected a nearly complete specimen, No. 9165, and the writer found a little more than the left half of a specimen, No. 9164, in the Lower Maquoketa on the Patrick Leehy farm near Clermont. One pygidium, No. 9261, from the Lower Maquoketa at Dover Mills, also is referred to this species.

\section{Basilicus cf. B. Barrand (Hall) Plate XVI, fig. 11.}

1851. Asaphus barrandi. Hall, Geol. Lake Superior Land Dist., Foster and Whitney's Rept., p. 210, pl. 27, figs. 1 A-D; pl. 28.

1897. Ptychopyge ulrichi Clarke, Geol. Minnesota, 3, pt. 2, p. 709, figs. 12,13 .

1914. Basilicus barrandi Raymond, Bull. Mus. Comp. Zool., 58, p. 261, pl. 1, figs. 4, 5 ; pl. 2, figs. 1, 7.

This species is represented in the University collection by a rather poorly preserved specimen, No. 9193, showing the pygidium in conjunction with eight thoracic segments. The thorax is convex and one-third wider than long. The axis is prominent, originating on a level with the pleuræ and rising considerably 
above them; anteriorly it occupies more than one-third the width of the thorax, thence diminishes abruptly and uniformly in size toward the pygidium where it occupies considerably less than one-third the width of the thorax. The segments are broad and gently rounded, each bearing a short and wide diagonal groove adjacent to each dorsal furrow and extending forward and upward from the posterior margin of the segment. The pleural lobes are flattened for one-half their width, thence descend abruptly to the margin. The proximal half of each segment is depressed and subequally divided by a broad shallow groove which begins in front at the axis and is thence directed outward in a gentle curve, ending near the posterior margin on the upper part of the sloping sides. The segments are.flattened distally, ending in a blunt point which is directed backwards.

The pygidium is subtriangular, the length is to the width as 2 is to 3 , the anterior margin is nearly transverse, the lateral margins converge rapidly to the sharply rounded posterior end. On each side of the axis there is a narrow flattened triangular area which descends abruptly to the broad shallow concave margin. Five annulations are discernible on the pygidium. These are smaller and increasingly oblique from front to back. The axis is well defined throughout; opposite the first two annulations it tapers abruptly, thence more gradually to a somewhat raised and obtusely rounded termination just above the concave border. The annulations appear to have been worn away.

The length of the thorax and pygidium is $78 \mathrm{~mm}$., the greatest width across the thorax is $63 \mathrm{~mm}$.

Position and locality.-Specimen No. 9193 was found in place in the Platteville limestone, along the Chicago, Milwaukee and St. Paul Railway right of way four miles north of Dubuque. Collected by C. C. Barnes.

Remarks.--The above described specimen represents all the material thus far recorded of the genus Basilicus from this state. Dr. Percy E. Raymond identified the specimen as probably belonging to $B$. barrandi; its poor state of preservation does not permit a more accurate determination. 


\section{Brachyaspis alachir (Billings) \\ Plate XIV, figs. 1-8.}

1866. Asaphus alacer Billings, Cat. Sil. Foss. Anticosti: Geol. Surv. Canada, p. 26, fig. 9 A.

1882. Asaphus susae (Calvin in MS.) Whitfield, Geol. Wisconsin, vol. 4, p. 236, pl. 5, fig. 3 ; pl. 10, fig. 8.

1883. Asaphus susae Chamberlin, Geol. Wisconsin, vol. 1, p. 160, fig. g.

1903. Asaphus (Isotelus) suscae Calvin, Iowa Geol. Surv. vol. XIII, p. 46 (footnote).

1912. Brachyaspis alacer Raymond, Trans. and Proc. Roy. Soc. Canada, 3rd ser., 5, sec. 4, p. 119.

"Body, when entire, more or less oval, the anterior and posterior extremities almost alike in form, the anterior border a little more sharply rounded than the other, and the sides of the body along the edges of the thorax straight. In profile, the body rises gradually from the middle of the caudal plate, along the thorax, and to the anterior border of the eyes; in front of which it abruptly declines to the firont margin of the head. Proportional width and length about as ten and twelve. In the specimens figured, the breadth is apparently somewhat greater, being as nine is to twelve, owing to the partial overlapping of two of the thoracic segments.

Cephalic shield crescent-form; the occipital line having a much longer curvature than the outer border, and the length, along the median line, equal to two-fifths of the transverse diameter, the sides of the head extending backward some distance behind the central portion, and the genal angles rounded. Surface very convex in middle, and nearly level on the top between the eyes, which are very distant, large and exceedingly prominent, strongly reniform, situated less than their length from the occipital border, and their visual surfaces highly convex. Facial sutures rounding outward in front of the eye for half the distance, then rounding rapidly inward and uniting in the middle just above or on the margin, in a very obtuse point. Behind the eye they are directed backward and outward, reacling the posterior border at a point about one-third the width of the lateral lobe from the dorsal furrow; the posterior lateral limbs being about twice as long as wide.

Thorax short, strongly lobed longitudinally, and consisting of eìght short articulations, which are nearly flat on their exposed surfaces from front to back, and their free extremities rounded. Axis convex, about once and a half as wide as the lateral lobes, and very slightly narrowed posteriorly. Lateral lobes horizontal 
for a short distance outside of the dorsal furrow, the flattening scarcely visible on the anterior segment, but gradually increasing in length to the sixth segment, when it again diminishes posteriorly. Beyond the horizontal part, the segments are abruptly bent downward, and the articulating face of the free pleura extends almost the entire width of the rib.

Pygidium depressed convex, transversely subelliptical, the length a little more than half the width, posterior margin almost regularly arcuate, and more strongly curved than the anterior border; so that a line drawn across the plate from the two outer angles would cross at about the anterior third of the length. Lobation very indistinct, the dorsal furrows being scarcely perceptible except near the anterior margin, and the articulation only faintly traceable. A perceptibly depressed furrow extends along the sides just within the margin.

Formation and locality.-In the limestones of the Trenton group at Apple River, just across the Illinois line." Whitfield 1882.

Position and locality.-Specimens Nos. 9166-9168 are from the upper part of the Galena-Platteville near Florenceville, Iowa. They belong in the Calvin collection (H. Saulisbury). No. 9171, an incomplete cranidium, was collected by the writer in the Lower Maquoketa shale, on the Patrick Leehy farm near Clermont.

Remarks.-The abrupt deflection of the head in front of the eyes differentiates this species from all other trilobites of this state. The Iowa material agrees fully with Whitfield's description, except that the anterior border of the cephalon is a little more broadly rounded than the posterior border of the pygidium. When naturally preserved the surface of the pygidium slopes evenly to the margin but in exfoliated specimens the margin is concave and marked by numerous subparallel lines. Whitfield's figure 8, Plate 10, is in striking agreement with our specimen No. 9166, but his figure 3 , Plate 5, which he says in explanation of Plate 10 is of the same specimen, has a much more broadly rounded posterior pygidial margin than any one of Calvin's specimens which Calvin used as the types of his Asaphus susae.

\section{Homotel us gratiosus Raymond Plate XVII, figs. 6, 7.}

1897. Asaphus (Isotelus) susae Whiteaves, Pal. Foss. Canada, 3 , pt. 3, p. 231 . 
1912. Onchometopus susae Raymond, Proc. and Trans. Roy. Soc. Canada, ser. 3, 5, sect. 4, p. 118, pl. 2, figs. 1, 2.

1920. Homotelus gratiosus Raymond, Bull. Mus. Comp. Zool., 64, No. 2, p. 291.

"Cephalon nearly semicircular, evenly conrex, with large, elevated eyes. Cranidium absent from the type, but on other specimens depressed, smooth, glabella not outlined. Fixed cheeks smooth, genal angles rounded. Eyes large, near the middle of the cephalon.

The axial lobe of the thorax is wide for a Homotelus, being nearly one-half the total width.

Pygidium short and wide, nearly semicircular, with the axial lobe outlined at the anterior end only.

Measurements.-Length of cephalon, $25 \mathrm{~mm}$., width, $51 \mathrm{~mm}$.; the eye is $10 \mathrm{~mm}$. long. Total width of thorax at middle, $48 \mathrm{~mm}$., width of axial lobe, $23 \mathrm{~mm}$. Length of pygidium, $26 \mathrm{~mm}$; width $46 \mathrm{~mm}$ :

This species differs from Homotclus florencevillensis, which occurs at the same horizon, in having the eyes much farther forward and larger, as well as in the shorter and wider shields. It differs from the other known species of the genus in the same particulars.

Horizon and locality.-The holotype, a gift of Mr. A. G. Becker and Mr. John H. Bradley, Jr., M. C. Z. 1.573, was found near the top of the Maquoketa at Pattersons Springs, near Brainard, Iowa." After Raymond 1920.

\section{Homotelus FLORENCEviLLensis (Calvin)}

$$
\text { Plate XIII, figs. 3, 4, } 5 .
$$

1894. Isotelus susae Clarke, Geol. Minnesota, 3, pt. 2, p. 708, text figs. 10, 11. Not Asaphus susae (Calvin in .MS.) Whitfield, Geol. Wisconsin, vol. IV, p. 236, pl. 5, fig..3, pl. 10, fig. $8,1882$.

1903. Isotelus florencevillensis Calvin, Iowa Geol. Survey, vol. XIII, p. 46. (In a footnote Calvin offers the name Isotelus florencevillensis because the name Isotelus susae used by Clarke for this form is preoccupied by Isotelus susae Whitfield which is a different form.)

1920. Homotelus florencevillensis (Raymond), Bull. Mus. Comp. Zool., vol. LXIV, no. 2, p. 291, July, 1920. Homotelus florencevillensis is here compared to $H$. gratiosus Raymond 1920, which occurs at the same horizon.

Description.-The general shape of the body is broad, de- 
pressed, gently and evenly convex, its outline is nearly oval, the sides of the thorax are straight, the eephalon is somewhat less broadly rounded than the pygidium. The width is to the length as five is to eight, or the width is equal to the median length of the head and thorax combined.

The cephalon is subcrescentic in outline, having a very broad curvature along the posterior margin, which is somewhat produced medially. The surface is evenly depressed convex except the narrow outer margin, which descends almost vertically. The length is to the width as one is to two. The cranidium is marked by shallow dorsal furrows which converge toward the palpebral lobes then diverge again to the end opposite the anterior angle of the eyes. The facial sutures originate on the posterior margin approximately half way between the genal angles and the dorsal furrows, whence they curve forward and inward to the eyes, in front of which they diverge, forming a sharp curve at the anterolateral angles of the cranidium, whence they continue centrally and unite in an obtuse point. The distance between the eyes is equal to a little more than twice their distance from the posterior margin of the eephalon. The free cheeks slope gently to the margin. $?$

The thorax is twice as wide as it is long, composed of eight segments. The surface is generally depressed except the nonarticulating portions of the pleuræ which slope strongly to the margin. Dorsally the segments are flattened on the axis and the proximal half of the pleuræ, which are marked by a faint wide groove. The width of the axis is to the width of the thorax as two is to five.

The pygidium is depressed convex, transversely subelliptical, the surface curving evenly to the margin, which is narrow and nearly horizontal posteriorly and still narrower and more sloping anteriorly. The length is to the width as three is to five. The axis is defined along the anterior margin only.

Dimensions.-Length of entire specimen, No. $9161,83 \mathrm{~mm}$.

Width of same $52 \mathrm{~mm}$.

Length of cephalon $26 \mathrm{~mm}$.

Length of thorax $27 \mathrm{~mm}$.

Length of pygidium $31 \mathrm{~mm}$. 
Position and locality.-Specimens Nos. 9161-9163 were collected by Dr. Samuel Calvin from the Maquoketa shales on the river above Florenceville. Number 9134 , a very small but nearly perfect specimen, was collected by the writer in the Isotelus zone, Elgin member of the Maquoketa at Dover Mills.

Remarks.-Specimen No. 91.61 is made the basis of the foregoing description. It is one of the forms referred to by Calvin in the footnote on page 46 of the Iowa Geological Survey, volume XIII. Specimen No. 9134 is doubtfully assigned to this species. It is a very young specimen which is similar in nearly all respects to the above described adult form but differs from it in possessing very short genal spines, a small median tubercle at the base of the glabella, and in having a narrow marginal area of the free cheeks nearly flattened instead of nearly vertical. These characteristics are very likely characteristics of youth. Dr. Percy E. Raymond ${ }^{5}$ agrees with the writer in the assignment of this specimen.

\section{Isoteluts gigas DeKay}

\section{Plate XV, figs. 1-3. Plate XXVII, fig. 21.}

1824. Isotelus gigas DeKay, Annals I.yceum Nat. Hist. New York, vol. 1, p. 176, pl. 12, fig. 1; pl. 13, fig. 1.

1832. Isotelus gigas Green, Mon. Tril. North America, p. 71, cast $21,22$.

1894. Isotelus gigas Clarke, Geol. Minnesota 3, pt. 2, p. 701, figs. $6-8$; p. 706.

1910. Isotelus gigas Raymond, Ann. Carnegie Mus., 7, p. 53, pl. 15 , figs. $1,2$.

1914. Isotelus gigas Raymond, Bull. Nus. Comp. Zool. 58, p. 248. pl. 1, figs. 1, 2; pl. 2, figs. 2-5; pl. 3, fig. 3 .

1916. Isotelus gigas Slocom, Iowa Geol. Survey, vol. XXV, p. 192.

Description.-Body form subelliptical in outline, moderately convex, trilobation distinct in the thorax only, outer marginal configuration of the head and tail shields similar. Length equals approximately two times the width.

Cephalon subtriangular in outline, bearing prominent depressed marginal borders which increase in width from genal 
angles forward; posterior margin gently concave. Length is to width as 2 to 3 . Cranidium evenly convex with the general surface of the cephalon and gently arched longitudinally. Greatest convexity opposite the palpebral lobes. Anterior margin depressed, forming a shallow concave groove with the free cheeks. Palpebral lobes subsemicircular, rising gently from the dorsal furrows and becoming nearly horizontal distally. Glabellæ are continuous with the lateral margins of the cranidium and defined by the dorsal furrows back of the eyes only except in depressed specimens where they diverge in front of the eyes, becoming continuous with the depressed marginal borders.

The facial sutures originate on the posterior margin of the cephalon nearly midway between the dorsal furrows and the genal angles, from whence ther converge in a curve to the eyes; in front of the eyes they diverge in an arcuate curve toward the marginal borders, thence run subparallel to the anterior margin, meeting in a distinct angle in front of the glabella within the anterior limbs of the free cheeks. Free cheeks large, rounded at the genal angles, produced anteriorly into narrow limbs which meet in front of the glabella, broadly depressed about the eyes thence sloping abruptly to the borders. Eyes prominent, lunate, situated slightly less than their own length in front of the posterior margin of the cephalon.

Thorax subquadrate, composed of eight segments, distinctly trilobate; dorsal furrows broad and shallow. Axis broad, depressed convex, not tapering but with sides gently rounded. Segments directed slightly forward on the sides, thence passing over the median area in a gentle posterior curve. Width of the axis is to the total width of the thorax as 3 to 8 . Pleural lobes flattened to depressed convex for about one-half their width from the axis, thence descending abruptly to the margin. Each segment bears a broad groove which passes obliquely ontward from the dorsal furrows to the descending portion. Beginning with the anterior margin at the fulcrum each segment is flattened distally toward the posterior margin.

Pygidium subtriangular in outline, anterior margin transverse across the axis, oblique at the sides. Marginal border broad, de- 
pressed and of uniform width from the articulating ring backward. Length is to width nearly as two is to three. Axis faintly defined at the anterior margin and at the nearly obsolete, narrow but obtusely rounded extremity well within the depressed border. General surface gently and evenly convex from the axial line outward. Depressed specimens show the axis better than normally preserved ones. Nearly all traces of segmentation are lost in young as well as old specimens.

Surface markings none.

Dimensions.-Specimen 9154, length $175 \mathrm{~mm}$., width at the genal angles $96 \mathrm{~mm}$., length of cephalon (estimated in part) 60 mm., length of thorax $46 \mathrm{~mm}$., width of thoracic axis $36 \mathrm{~mm}$., length of pygidium $69 \mathrm{~mm}$., width of same $92 \mathrm{~mm}$.

Position and locality.-Number 9154 is from the Elgin member of the Maquoketa at Florenceville, collected by Professor Calvin. Number 9150, an even larger specimen than No. 9154, but much exfoliated and showing the Panderian organs, appears to come from the Elgin member of the Maquoketa at Dover Mills. The exact locality is unknown, but the matrix in which the specimen is preserved is identical with that of the Isotelus zone at Dover Mills. Number 9151 was collected by the writer from the Lower Maquoketa shales in the southeast quarter of the northwest quarter of section 19, Madison township, Winneshiek county. Number 9155, a specimen showing a hypostoma, was collected by Professor Calvin in the Elgin member of the Maquoketa about onehalf mile east of Nordness, Winneshiek county.

Remarks.-Isotelus gigas is distinguished from. I. maximus and from $I$. iovensis by the long subtriangular cephalon and pygidium, the outline of the anterior portion of the cranidium and the absence of genal spines. In I. gigas the cranidium is greatly extended and the antero-lateral margins converge uniformly, meeting in a distinct angle. In $I$. maximus the cranidium is less extended; the antero-lateral margins.approach each other more abruptly until near the center whence they curve abruptly forward to meet in a short sharp angle. In $I$. iowensis the anterior part of the cranidium is distinctly rounded, forming the anterior margin of the cephalon. The outline and general pro- 
portions are quite similar to those of 1 . iowensis though the pygidial axis of the latter is much more distinct and shows traces of segmentation. Both the cephalic and pygidial shields of 1 . maximus are proportionally shorter and wider than those of $I$. gigas.

Owing to careful investigations of this and allied species by Raymond, Slocom and others it is found to be less common than it was thought to be by the earlier writers in this state. Careful collecting has revealed fewer specimens of $I$. gigas than of other members of this genus such as 1 . iowensis and 1 . rejuvenis.

\section{Isotelus iowensis Owen}

\section{Plate XVI, figs. 6-10.}

1852. Isotelus iowensis Owen, Rep. Geol. Surv. Iowa, Wisconsin and Minnesota, p. 57 7 , pl. IIa, figs. 1-7.

1913. Isoletus iowensis Slocom, Field Mus. Nat. Hist., Geol. Ser., vol. 4, p. 48, pl. XIII, figs. 1, 2.

1916. Isoletus iouensis Slocom, Iowa Geol. Survey, vol. XXV, Annual Rep. 1914, p. 193, pl. XIV, figs. 1, 2.

"The general form and contour of the cephalic shield closely resembles that of $I$. gigas DeKay; but the facial sutures do not converge in front to form a distinct angle, but describe three parts of a circle as in Asaphus expansus. The eyes are reticulated and the middle lobe of the caudal shield is defined (though sometimes somewhat indistinctly), but the segments are only obscurely pronounced. The glabella is but obscurely defined, and the genal angles are produced into spines. The thorax consists of eight segments.

"From I. megistos, it differs in the eyes being: set closer together; in the spines being longer, extending as low as the caudal shield; the pygidium more regularly elliptical, and its axial lobe more distinctly defined.

"From the bituminous limestone, mouth of Otter creek, Turkey river, Iowa."

The original description, of which the above is practically a copy, is so incomplete that it seems advisable to redescribe the species in more detail.

Body subelliptical, length about twice the greatest breadth, moderately convex, trilobation not well developed. Entire surface finely punctate, the puncta being larger and more pronounced on the free cheeks and less conspicuous on the marginal borders than on other parts of the test. 
Cephalon semioval in outline, marginal border defined by a marginal furrow which originates on the genal spines as an angular groove and develops into a shallow concave furrow gradually widening to the front of the glabella. Dorsal furrows shallow, converging toward the median line in passing the palpebral lobes, then diverging to about their original distance apart. Cranidium moderately convex, greatest convexity just in front of the eyes, concave where the marginal furrow crosses it. The anterior margin of the cranidium forms the margin of the cephalon. Fixed cheeks very small, not well defined. Free cheeks large, with long genal spines, convex near the eyes, not produced in front of the glabella. The facial sutures originate on the posterior margin of the cephalon about midway between the dorsal furrows and the lateral margins, from whence they converge forward in a sigmoid curve to the crest of the eye lobes, which they follow, thence forward and outward in an arcuate curve, meeting the anterior margin of the cephalon in front of the anterior angles of the eyes; here the sutures bifurcate, one fork following the anterior margin until it meets the fork from the other.side in a continuous curve or slight angulation, never in a distinct angle; the other fork passes over the margin and curves across the doublure to the base of the hypostoma. Hypostoma forked posteriorly, only slightly constricted at the base, greatest width about three-fifths the length. Compared with I. gigas the forks point more directly backward making the notch between them narrower. Eyes lunate, prominent, situated less than their own length in front of the posterior margin of the cephalon, rather near together for the genus. A rather indistinct posterior cheek furrow extends across the fixed cheeks. Occipital ring and furrow obsolete.

Thorax composed of eight segments. Dorsal furrows shallow, ill-defined; axial lobes depressed convex, not tapering, occupying more than one-third but less than one-half the width of the thorax; pleural lobes curving gently upward from the dorsal furrows, then more abruptly downward to the lateral margins; each ségment arching gently forward on the axial lobe, and curving slightly backward towards the extremities of the pleuræ. A shallow concave furrow crosses the axial lobe, originating on the posterior margins at the dorsal furrows. A more pronounced subangular furrow originates on the anterior margin of each pleura at the dorsal furrows and passes diagonally outward and backward about three-quarters the length of the pleura. The distal portion of each pleura is distinctly flattened anteriorly. The flattening occupies nearly the entire width at the rounded 
extremity of the pleura but gradually narrows towards the dorsal furrow until it disappears.

Pygidium slightly narrower and longer than the cephalon, rather more convex, with a marginal border of uniform width. Axial lobe tapers abruptly near its anterior margin, thereafter only moderately to its prominent, rounded termination, no annulations visible. The segmentation of the pleural lobes is obscure although three or four segments may be distinguished on young individuals. All markings are more distinct on young than on older individuals.

Measurements.-The figured specimen (Field Mus. No. P 11241) measures: Cephalon $36.5 \mathrm{~mm}$. long, $63.5 \mathrm{~mm}$. wide, thorax $33 \mathrm{~mm}$. long. Another (Field M[us. No. P 6969) measures: Cephalon $21 \mathrm{~mm}$. long, $36 \mathrm{~mm}$. wide, thorax $18.5 \mathrm{~mm}$. long, $36 \mathrm{~mm}$. wide. Pygidium $24.4 \mathrm{~mm}$. long, $34 \mathrm{~mm}$. wide, entire length $63.9 \mathrm{~mm}$.

Remarks.-Specimens of this species have been usually referred to 1. maximus Locke, but the writer is convinced that they belong to Owen's species as the Field Museum collection contains one nearly complete individual and quantities of less complete ones that were collected at the type locality which agree with Owen's description. The character which most easily distinguishes 1 . iowensis from 1 . maximus is the position of the facial sutures. In 1 . iowensis they follow the anterior margin of the cephalon and unite in a curve or indistinct angle. In 1 . maximus the sutures run subparallel to the anterior margin and meet in a distinct angle so that the free cheeks are produced in front of the glabella, while in 1 . iowensis the cheeks terminate in front of the eyes. Owen describes the genal spines as extending the entire length of the thorax, but his original figures show the spines much shorter. In the specimens before the writer the length of the spines seems to be a variable character.

Locality and horizon.- "Isotelus Zone" near the base of the Lower Maquoketa beds near where Otter creek empties into Turkey river at Elgin, and at Clermont. An hypostoma, undoubtedly belonging to this species, was found on a slab at the top of the Upper Maquoketa beds at Pattersons Springs." After Slocom 1916.

Isotelus iowensis is similar in most respects to Isotelus rejuvenis Raymond, with which it is commonly associated, but it differs from the latter in having somewhat larger eyes, a shorter and wider pygidium which is more nearly smooth in adult specimens and a more densely punctate surface. In addition Raymond ${ }^{6}$ in-

6 Raymond, personal communication, August 15, 1922. 
forms the writer that if the ratio of length of pygidium divided by the width of same is less than 80 it is $I$. iowensis and if the ratio is greater than 80 it is 1 . rejuvenis.

The hypostoma from the Elgin member of the Maquoketa at Elgin, figured by Slocom, 1916, Plate XIV, figure 2, is No. 9147 in the University collection. All of the material at the University is from the Elgin member. Number 9140 is an impression of a nearly perfect specimen collected by Professor Calvin at Clermont. Numbers 9142, a hypostoma, 9143, a glabella, and 9148, two small pygidia, are all from the Isotelus zone at Dover Mills. Numbers 9144, a small nearly complete specimen, and 9145, a large free cheek showing genal caeca, are from Elgin. Number 9158, the ventral side of a cephalon, is from the southeast quarter of the northwest quarter of section 19, Madison township, Winneshiek county. Besides this there is a great deal of uncatalogued material in the collection.

\section{Isotelus ReJuVENis Raymond}

Plate XVII, figs. 8, 9.

1920. Isotelus rejuvenis Raymond, Bull. Mus. Comp. Zool., Harvard College, vol. LXIV, No. 2, p. 294, July, 1920.

"Entire specimen elongate oval, narrow, strongly convex. Cephalon large, with short genal spines which in uncrushed specimens have their outer surfaces nearly vertical. The facial sutures follow the same course as in 1 . iowensis, being very close to, and parallel to the anterior margin. The eyes are very small, elevated, situated a trifle more than their own length in front of the posterior margin. The glabella is faintly outlined, constricted between the eyes, and nearly smooth.

Thorax as in I. iowensis, the dorsal furrows shallow, and the axial lobe more than one-third and less than one-half the total width.

Pygidium elongate, narrow, with steep sides. The axial lobe is narrow, faintly outlined except in young specimens, and without rings except for the one on the anterior end. The pleural lobes show traces of several pairs of ribs, two of which at the anterior end are very distinct.

Measurements.-The holotype is $105 \mathrm{~mm}$. long; the cephalon is $38 \mathrm{~mm}$. long and $62 \mathrm{~mm}$. wide; the pygidium is $46 \mathrm{~mm}$. long and $55 \mathrm{~mm}$. wide. 
This species differs from Isotelus iowensis in having smaller eyes, a longer and narrower pygidium with two pairs of ribs at the anterior end, and in having a less densely punctate shell.

Horizon and locality.-The species has so far been found only in the lower part of the Maquoketa at Clermont and Elgin, Iowa, at both of which places it is rather common in association with I. iowensis. The holotype, M. C. Z. 1,586, was collected by the writer on a creek about four miles west of Clermont." After Raymond 1920.

Remarks.-Doctor Percy E. Raymond informed the writer that one of the principal differences between the pygidium of this species and that of $I$. iowensis is the proportion of length to width. If the length divided by the width is less than 80 it is $I$. iowensis, if it is greater than 80 it is I. rejuvenis. In the University of Iowa collection there is a slab of limestone, No. 9141, from the Elgin member of the Maquoketa at Elgin which contains five or six imperfectly preserved specimens. Number 9146 , a pygidium with eight thoracic segments in place, and No. 9153 are from the Elgin member of the Maquoketa at Dover Mills. Numbers 9149 and 9150 , two pygidia, are from the same horizon in section 19, Clermont township, Fayette county. The collection also contains considerable uncatalogued material of this species.

\section{Family ILLAENIDAE}

\section{IrLAENUS americañus Billings}

Plate XVII, fig. 1.

1847. Illaenus crassicauda Hall, Pal. New York, vol. I, p. 24, pl. 4 (bis), fig. 13, (not Wahlenberg).

1859. Illaenus americanus Billings, Canad. Nat. and Geol., vol. 4, p. 371.

1861. Illaenus taurus Hall, Geol. Surv. Wisconsin; Rept. Progress, p. 49.

1865. Illaenus americanus Billings, Paleozoic Fossils, vol. 1, Geol. Surv. Canada, p. 329, figs. 316a-d, 318 .

1868. Illaenus taurus Meek and Worthen, Geol. Surv. Mlinois, 3, p. 320, fig. 2. Galena, Illinois.

1894. Illaenus americanus Clarke, Geol. Minnesota 3, pt. 2, p. 714, figs. 20-23. Galena limestone.

1908. Illaenus taurus Rowley, Missouri Bur. Geol. and Mines, 2nd ser., vol. 8, p. 57, pl. 15, fig. 1. Trenton limestone (Receptaculites oweni horizon), Pike county, Missouri. 
Description.-Pygidium transversely subelliptical in outline, strongly convex, length to width as 3 to 5; posterior margin smooth, broadly and evenly rounded, anterior margin transverse medially, obliquely truncated laterally. Axis short, subconate, strongly rounded anteriorly and tapering rapidly to an obsolete termination at the pleural geniculation; width slightly less than. one-third the width of the shield. Pleural lobes depressed or flattened near the axis, thence sloping abruptly along a gentle curve to the margin. Surface marking's none.

Dimensions.--Specimen 9173 , length along median curvature 16 mm., width $27 \mathrm{~mm}$.

Position and locality.-Galena dolomite, in quarries on West Fourteenth St., Dubucue.

Remarks.--The specimen described is an internal cast collected by the writer. It represents all the material of this species at the University though it has been reported by Leonard (Iowa Geol. Survey, vol. XVI, p. 254) from the Upper Platteville about ten to fifteen feet below the Galena dolomite, along a small creek about one mile southwest of Elkader. Savage (Iowa Geol. Survey, vol. $\mathrm{XV}$, p. 462) also reports an undetermined species of Illaemus' in a zone about fifteen feet below the top of the Galena-Platteville along Turkey river at Clermont. This specimen very likely was Illaenus americanus since it appears to be limited to a very definite vertical horizon not only in this state but in the adjacent states of Minnesota, Wisconsin, Illinois and Missouri as well.

\section{Bumastus Beckeri Slocom \\ $\cdot$ \\ Plate XVIII, figs. 10, 11.}

1913. Bumastus beckeri Slocom, Field Mus. Nat. Hist., Geol. ser., vol. 4, p. 54, pl. XIV, figs. 1-4.

1916. Bumastus beckeri Slocom, Iowa Geol. Survey, vol. XXV, Ann. Rep. 1914, p. 201, pl. XV, figs. 1-4.

"Type specimens.-Holotype in collection of Mr. A. G. Becker, one, paratype in collection of State University of Iowa, and the other No.'P 16708 Field Museum.

Description.-Body oblong, slightly ovate, width at the genal angles about half the entire length. Dorsal furrows nearly obsolete on the cephalon and thorax and entirely so on the pygi- 
dium. Surface, except in the region of the palpebral lobes, dorsal furrows and the anterior central portion of the glabella, marked with indented, transverse lines, more or less parallel to each other and to the transverse divisions of the test. These lines are conspicuous and close together on the doublure, somewhat less so on the cephalon and anterior segments of the thorax. On the posterior segments and pygidium they are inconspicuous and discernible only with a magnifier.

Cephalon strongly convex, semicircular in outline; the location of the dorsal furrows indicated by two almost imperceptible grooves leading up to longitudinally elongate depressions situated just in front of a line joining the anterior edges of the eyes and somewhat nearer to the eyes than to the median line of the cephalon. These depressions appear as sublunate grooves on the casts, but on the surface of the test only as a slight flattening. The regular curvature of the cephalon, aside from the flattening just referred to, is interrupted only by the palpebral lobes. Eyes far apart, situated at about half their length from the posterior margin of the cephalon. Facial sutures originate on the posterior margin of the cephalon on a level with the lower edges of the eyes, from whence they pass forward and upward around the eyes, thence obliquely downward to the antero-lateral margin of the cephalon. Free cheeks small, genal angles obtusely rounded. Occipital ring not discernible on either test or cast.

Thorax composed of ten segments, smooth and flat, gradually narrowing to the almost obsolete dorsal furrows, at which points they bend backward and downward to the lateral margins; the axis occupies about two-thirds of the width of the thorax; dorsal furrows appear on the casts as two parallel grooves.

Pygidium strongly arched, transwersely oval, length about two-thirds the width, no trace of the dorsal furrows.

Five specimens were used by the writer in making this description. The holotype is an enrolled specimen having a portion of the front of the cranidium missing. It is in the private collection of Mr. A. G. Becker. A paratype consists of a complete cephalon attached to nine complete thoracic segments and a portion of the tenth. This specimen was collected by Professor Calvin and is a part of the geological collection of the State University of Iowa. The other paratype is a pygidium attached to the seven posterior thoracic segments. It belongs to the Field Museum collections (Field Mus. No. P 16708). Two somewhat distorted natural casts (Field Mus. No. P 16854) also were used in making this description. These casts were presented to the Field Museum by Mr. Becker. The dimensions of the type specimens are as follows: 
Holotype: Cephalon $18 \mathrm{~mm}$. long, $31.5 \mathrm{~mm}$. wide; pygidium 15 $\mathrm{mm}$. long, $26.4 \mathrm{~mm}$. wide; distance around the coiled specimen $74.5 \mathrm{~mm}$. Allowance for the convexity of the cephalon and pygidium would make the length, if the specimen were unrolled, about $60 \mathrm{~mm}$. Specimen from the State University of Iowa: Cephalon $19.6 \mathrm{~mm}$. long, $32.3 \mathrm{~mm}$. wide and $18 \mathrm{~mm}$. thick. Specimen $\mathrm{P}$ 16708: Pygidium $11 \mathrm{~mm}$. long, $19 \mathrm{~mm}$. wide, length of pygidium and the seven posterior segments of the thorax $33 \mathrm{~mm}$.

Remarks.- Specimens of this species have been referred to $B$. orbicaudatus Billings by Calvin, Savage and others in the various Iowa reports. B. orbicaudatus was originally described from a pygidium only and a complete specimen was afterwards figured by Billings. Referring to this description and figure, it is evident that $B$. beckeri is quite distinct from $B$. orbicaudatus. The cephalon and pygidium are much longer in proportion to their width, and the dorsal furrows are much more distinct in $B$. orbicaudatus. The orbicular axis of the pygidium, which is the distinguishing character of $B$. orbicaudatus, is missing in $B$. beckeri. $B$. beckeri seems to be most closely related to $B$. billingsi Raymond and Narraway, from the Trenton limestone of Canada, but it is considerably narrower in proportion to its length, the trilobation is much less pronounced and no mention is made in the description of $B$. billingsi of any transverse lines on the test.

The specific name is given in honor of Mr. A. G. Becker, whose collection contains the holotype.

Locality and horizon.-All specimens observed are from the Lower Maquoketa beds of Clermont." After Slocom 1916.

Dismembered parts and occasional complete specimens of $B$. beckeri are found in the Lower Maquoketa of Fayette county. Number 9256, a lot of six cranidia and one pygidium, is from the Patrick Leehy farm near Clermont, collected by Professor Thomas and the writer. Numbers 9257 a, a paratype used by Slocom, and $9257 \mathrm{~b}$ were collected by Professor Calvin at Clermont. Number 9258 , a very large well preserved specimen was collected by Professor Thomas at Clermont.

\section{Bumastus milleri (Billings)}

Plate XVII, fig. 2.

1859. Illàenus milleri Billings, Canadian. Nat. and Geol. vol. 4, p. 375 , fig. 10.

1897. Bumastus trentonensis Clarke, Geol. Minnesota 3, pt. 2, 
1897, p. 718, figs. 30-35. Trenton limestone, Minneapolis and St. Paul, Minn.; Dixon, Illinois ; Platteville, Wisconsin.

1908. Bumastus milleri Raymond and Narraway, Ann. Carnegie Mus., 4, 1908; p. 249, pl. 61, figs. 9, 10; pl. 62, figs. 3-5.

This species is represented in the University collection by an incomplete cranidium, No. 9191, from the Platteville limestone along Sny Magill creek in Clayton county. The specimen is quite globose and almost completely exfoliated, showing a very faint trace of the dorsal furrows, which end opposite the anterior portion of the eyes in a pair of small oval-elongate impressions. The eyes and free cheeks are missing.

It is not surprising that this species should be found in this state since it is reported by Clarke, above referred to, at a similar horizon in three adjoining states.

Position and locality.-Number 9191, Platteville limestone, along Sny Magill creek, Clayton county.

\section{Bumastus species \\ Plate XVIII, fig. 12.}

A number of years ago while collecting in the Maquoketa shales at Graf, Iowa, the writer found the impressions of an incomplete Bumastus, No. 9159, associated with Diplograptus peosta in a thinly laminated bituminous shale. The entire specimen, including the pygidium and five complete and two incomplete thoracic segments, is entirely flattened except the terminal parts of the pleural segments, which descend abruptly. The axis of the thorax is faintly outlined and occupies nearly two-thirds of the entire width of the thorax. The pygidium is subsemicircular in outline; the length is to the width nearly as one is to two; the anterior margin is gently curved. It bears no traces of an axis or of annulations.

It is hoped that more and better material of this form will be found so that the specific identity of the only Bumastus thus far found in this locality can be determined.

Position and locality.-Lower Maquoketa shale, in zone 4 of 
Professor Thomas' "Section of the railway cut near Graf, Iowa." "r

\section{Thateops ovata Conrad \\ Plate XVII, figs. 3-5.}

1843. Thaleops ovata Conrad, Proc. Acad. Nat. Sci. Philadelphia, vol. I, p. 332.

1882. Illaenus ovatus Whitfield, Geol. Wisconsin, vol. IV, p. 238, pl. 5, figs. 1-2.

1897. Thaleops ovata Clarlze, Pal. Minnesota, vol. III, pt. 2, p. 716, figs. 17-19.

1913. Thaleops ovata Slocom, Field Mus. Nat. Hist., Geol. Ser., vol. 4, p. 56, pl. XIV, figs. 6-8.

1916. Thaleops ovata Slocom, Iowa Geol. Survey, vol. XXV, Annual Rep. 1914, p. 204, pl. XV, figs. 6-8.

"Body broadly ovate, widest at the base of the cephalon, distinctly trilobed, length about equal to the width at the eye lobes.

Cephalon broadly semicircular on the anterior margin, very highly convex. Dorsal furrows clearly defined on the posterior third of the cephalon, obsolete in front. Glabella convex between the dorsal furrows, not defined in front. Eyes small, pedunculate, extending laterally and horizontally. Occipital segment and furrow very faintly marked, rounded backward. Free cheeks small, produced laterally at the genal angles into blunt spines. The facial sutures rise rapidly from the posterior margin to the summit of the eye lobes, thence round gradually forward to the anterior margin, which they intersect in front of the dorsal furrows.

Thorax wider than long, tapering, composed of ten smooth, slightly convex segments. Axial lobe depressed convex, narrower than the lateral lobes, segments arched forward. Pleuræ flat for more than half their width from the axis, then bent downward, segments strongly recurved toward their extremities.

Pygidium nearly flat on top and curving abruptly to the margins, short, subquadratic. The posterior margin forms a very broad curve, width about twice the length. Axis prominent, narrower than the thoracic axis, tapering slightly and terminating bluntly in an elevated extremity, which is faintly bilobed; axis entirely surrounded by the dorsal furrows; annulations of the axis nearly obsolete.

The surface of the cephalon is covered with epidermal punctæ

7 A. O. Thomas, Iowa Acad. Sci., vol. 21, pp. 225-229, 1914. 
except in the dorsal furrows and on the palpebral lobes. On the cheeks and anterior portion of the glabella the punctæ are vertical and isolated, on the posterior surface of the glabella they are oblique and crowded. The surface of the thorax appears to be smooth. Doublure marked with prominent lines parallel to the anterior margin. Pygidium sparsely punctate on the posterior margin but on the anterior portion the punctations are deep, coarse, and arranged in transverse rows.

The foregoing description is based on a practically complete specimen from the Platteville beds at Mineral Point, Wisconsin, in the paleontological collection of the University of Chicago. The Fayette county specimens have been compared with the Platteville specimen and agree so well that they must be considered to be specifically identical, although previously $T$. ovata has been found only at lower geological horizons.

This species is represented in the Field Museum collections from Fayette county by a nearly complete cranidium from the Lower Maquoketa at Clermont and another from the Upper Maquoketa at Pattersons Springs." After Slocom 1916.

This species is represented in the University collection by a cast of a nearly complete individual, No. 9251, which is somewhat distorted.- This specimen comes from the Platteville limestone at Beloit, Wisconsin. The following specimens are all from the Platteville limestone about one mile southwest of McGregor along the road to Pikes Peak: No. 9194, a complete pygidium; No. 9195, a pygidium in conjunction with the thorax; Nos. 9196 and 9197 are two cranidia. The species has been recorded also from Decorah by Clarke, 1897, page 718, referred to above.

\section{Family LICHADIDAE}

Amphrichas rhinoceros Slocom

Plate XVIII, figs. 7, 8.

1913. Amphilichas rhinoceros Slocom, Field Mus. Nat. Hist., Geol. Ser., vol. 4, p. 58, pl. XV, figs. 5-6.

1916. Amphilichas rhinoaeros Slocom, Iowa Geol. Survey, vol. XXV, Ann. Rep. 1914, p. 206, pl. XVI, figs. 5-6.

“Type specimen No. P 11181 Field Museum.

Glabella large, occupying nearly the entire width of the cranidium, depressed convex posteriorly, inflated in front, subpentangular in outline, rounded anteriorly, greatest width just in front 
of the eyes; the single pair of glabella furrows originates on the lateral margins; curves gently inward and backward for about half the length of the glabella, thence backward subparallel until these furrows join the occipital furrow. They thus divide the glabella into a median and two lateral lobes. Median lobe broad in front, posterior half only slightly convex, anterior half abruptly inflated, length about two and one-half times the width at the occipital furrow. Lateral lobes undivided, margins subparallel, width about equal to that of the median lobe, moderately convex except in front where they bend outward and downward to the lateral margins; greatest elevation near the dorsal furrows in line with the palpebral lobes, where large nodes rise abruptly from the dorsal furrows but elsewhere gradually; these nodes form the bases of the two long lateral spines. The occipital segment forms a wide depressed transverse band, widest in the middle and gradually narrowing towards the dorsal furrows; poster. ior margin slightly concave, with a well developed doublure. Dorsal furrows, as well as glabella and occipital furrows, narrow but well defined. Fixed cheeks small, depressed, convex, aside from the palpebral lobes, which rise abruptly; the only portion of the palpebral lobes observed is that attached to the fixed cheek. This is elevated, lunate in form with the convex side toward the dorsal furrows. The marginal border of the cephalon is represented by only a single, somewhat crushed fragment, but this fragment indicates that there was a narrow marginal border similar to that of $A$. bicornis Ulrich. Eyes and free cheeks not preserved. Surface of the cephalon finely papillose, with tubercles of various sizes more or less regularly arranged thereon. Two of the larger of these tubercles occur along the median line of the glabella, one on each lateral lobe, and three form a transverse row on the occipital segment; aside from these tubercles, the inflated anterior portion of the glabella supports a pair of recurved hornlike processes, $2.5 \mathrm{~mm}$. in diameter and $29 \mathrm{~mm}$. long (measured on the outer side of the curve); these processes diverge somewhat and curve upward, then backward. Another pair of processes of about the same size occurs, one on each lateral lobe of the glabella, near the dorsal furrow, in line with the eyes. Exact length of the lateral pair of processes not known.

Thorax and pygidium unknown.

The specimen (Field Mus. No. P 11181) on which the above description is based consists of a nearly complete cranidium of which the inner surface of the test is exposed with one of the anterior horns complete and in natural position and one of the lateral ones bent outward with the end missing. The dimensions 
are as follows: Length of cranidium, along the median line, 32 $\mathrm{mm}$.; greatest width of glabella (in front of eyes) $42 \mathrm{~mm}$.; width of median glabella lobe on anterior margin $18 \mathrm{~mm}$.; width at occipital furrow $11.5 \mathrm{~mm}$. ; width of lateral lobes $11.5 \mathrm{~mm}$.; width of occipital segment on median line $7 \mathrm{~mm}$.; width at dorsal furrows $5.5 \mathrm{~mm}$.

Remarks.-In general form and proportion the cranidium above described approaches $A$. bicornis Ulrich, from a similar horizon in Minnesota, but is distinguished from that species by the number and position of the hornlike processes as well as by the variation in size of the surface tubercles; also in a side view of the glabella of $A$. bicornis the outline of the surface is convex, while in $A$. rhinoceros the outline near the middle is concave, due to the inflation of the anterior portion.

Locality and horizon.- TJpper layers of the Lower Maquoketa beds at Elgin." After Slocom 1916.

No additional material of this very rare and interesting species has been found to date since Slocom's work on $A$. rhinoceros.

Amphrichas CLermontensis Slocom

Plate XVIII, fig. 9.

1913. Amphilichas clermontensis Slocom, Field Mus. Nat. Hist., Geol. Ser., vol. 4, p. 59, pl. XV, fig. 7 .

1916. Amphilichas clermontensis Slocom, Iowa Geol. Survey, vol. XXV, Ann. Rep. 1914, p. 207, pl. XVT, fig. 7.

“'Type specimen No. P 11257 Field Museum.

Cephalon subtriangular, broadly rounded anteriorly, much shorter in proportion to the width than $A$. rhinoceros. Glabella convex, greatest elevation just in front of the center, to which point it rises gradually from the posterior and lateral margins and much more abruptly anteriorly; subpentangular in outline, widest in front of the eyes; a single pair of glabella furrows originates on the lateral margins, curves abruptly inward and upward, then converges backward until it meets the occipital furrow, forming a large median lobe and two smaller lateral lobes. Median lobe very broad anteriorly, more than twice the width at the occipital furrow. It comprises nearly two-thirds of the glabella. Lateral lobes undivided, margins subparallel, conforming to the general convexity of the glabella, abruptly bent downward anteriorly. Occipital segment a flat or slightly concave transverse band, widest at the juncture of the occipital and glabella furrows, narrowing slightly to the median line and more so later- 
ally. Occipital and glabella furrows narrow but distinct. Surface smooth to the naked eye, but a magnifier shows it to be covered with variously sized pustules. No nodes or spines interrupt the regular curvature of the cephalon.

Thorax and pygidium unknown.

The specimen here described (F'ield Mus. No. P 11257) consists of an incomplete glabella. The cheeks and marginal border are entirely missing. The median lobe and one lateral lobe are nearly complete, and the other lateral lobe is somewhat less so. The occipital, one dorsal and the glabella furrows are well indicated and the median portion of the occipital segment is intact. While the specimen leaves much to be desired, ret the generic characters are well shown and the specific characters fairly well.

The dimensions are as follows:

Length of glabella on median line (exclusive of oc-

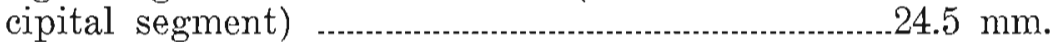

Greatest width of glabella (in front of the eyes) $\ldots . . . .30 \mathrm{~mm}$.

Width of glabella at occipital furrow ...................... $26 \mathrm{~mm}$.

Width of median glabella lobe on anterior margin,

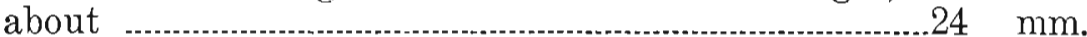

Width of median glabella lobe on occipital furrow -.. $11.5 \mathrm{~mm}$.

Width of lateral glabella lobes................................ $8.5 \mathrm{~mm}$.

Length of lateral glabella lobes....................................17 $\mathrm{mm}$.

Width of occipital segment on median line..............- $3.5 \mathrm{~mm}$.

Width of occipital segment behind glabella furrows.... $4.2 \mathrm{~mm}$.

Amphilichas clermontensis is distinguished from the other members of this genus by the much greater width of the glabella in proportion to its length and by its more nearly arcuate curvature both longitudinally and transversely. In surface ornamentation it resembles $A$. circullus from the Trenton, but in form it is quite distinct from that species.

Locality and horizon.-Lower Maquoketa Beds, Clermont." After Slocom 1916.

The specimen described by Slocom represents all the known material of this species. The collecting trip in northeastern Iowa added no representative of this rare species.

Remarks.-Foerste ${ }^{8}$, who has made a very thorough study of the American Lichadidae, has suggested that $A$. rhinoceros and $A$. clermontensis of Slocom probably belong to his new genus Acrolichas. The genus Acrolichas, according to Foerste, differs

8 The Generic Relations of the American Lichadidae. By Aug. F. Foerste, Am. Jour. Sci.. vol. XLIX, pp. 26-50, with 2 text figs. and 4 plates, Jan., 1920. 
from Amphilichas of Europe primarily in the character of the pygidium. The axial labe of the pygidium of the latter is somewhat constricted near the middle, widening toward both ends, whereas on the former, the typical American genus, the axial lobe of the pygidium tapers posteriorly to a point which ends in the notch between the posterior pair of lateral ribs.

Since the pygidia of Slocom's species are not known and since the cranidia of the two genera under consideration are almost identical it seems best to retain these species under the generic name Amphilichas until further investigation reveals pygidia which will show undoubted Acrolichas characters. That these species will very likely be placed with Acrolichas is foreshadowed by the fact that Dr. Foerste shows quite clearly that Acrolichas is typically American and Amphilichas typically European in geographical distribution.

\section{Family ODONTUPLEURIDAE Burmeister \\ Genus Ceratocephata Warder \\ Ceratocephala maquoretensis $n$. $s$. Plate XVIII, figs. 2, 3.}

Description.-Size very small, strongly trilobate, the lateral margins of the head and thorax bordered with spines. Pygidium unknown.

Cephalon subcrescentiform in outline, depressed convex, produced into long narrow divergent spines at the genal angles; entire margin thickened into a narrow encircling ridge which bears about twelve spines on each free cheek between the genal angles and the anterior limb of the facial suture. A marginal sulcus extends parallel to the marginal ridge from the genal angles to the anterior end of the cephalon and is narrower in front of the glabella. Glabella prominent, depressed below the fixed cheeks posteriorly, subrectangular, widest across the basal lobes, and well defined by the dorsal furrows; median lobe elongate, transversely elliptical and widest in front, parallel-sided posteriorly and extending from the anterior marginal sulcus to the occipital groove. There are two pairs of isolated lateral lobes; the first 
pair is oval elongate subparallel to the long axis of the glabella; the second pair is much larger, rounded posteriorly, pointed anteriorly, and directed obliquely outward and forward. The two anterior lateral furrows are deep, directed obliquely inward, somewhat wider and shallower where they pass backward along the median lobe. The second lateral furrows are larger than the first, also directed obliquely backward, shallower along the median lobe and continuing posteriorly to the occipital groove. A pair of small indistinct occipital lobes is present at the anterolateral angles of the occipital segment. Occipital segment broad, gently arched, bearing a strong median tubercle and two divergent spines from the postero-lateral angles. (The specimen being an internal cast of the dorsal crust the length of these occipital spines can not be measured without destroying a part of the thorax.) Occipital groove wide, shallow and smooth.

Fixed cheeks prominent, rising strongly above the posterior surface of the glabella to the eyes; sloping gently forward toward the anterior margin from the eyes and abruptly backward and downward to the deep groove which extends along the posterior limb of the fixed cheeks from the dorsal furrows to the genal angles. A narrow sharp occular ridge, bounded on each side by equally narrow grooves, connects the eyes with the antero-lateral angles of the median glabellar lobe. The eyes are small, strongly elevated and situated about their own length in front of the posterior margin of the cephalon.

The facial sutures originate at the genal angles, pass a short distance forward parallel to the outer margin of the free cheeks, curve sharply inward and continue obliquely to the eyes; in front of the eyes they describe a gentle arcuate curve cutting the anterior margin of the cephalon in a straight line in front of the inner margin of the eyes. Entire surface, except grooves, strongly tuberculate.

The thorax is represented by eight complete segments and the pleural portion of the ninth. The axis is well defined, narrow, moderately convex, less than one-third the width of the thorax exclusive of the marginal spines; the sides are straight, tapering gently posteriorly. The segments are rounded and covered with 
spinelike tubercles; those near the dorsal furrows are small and irregularly arranged; the remaining tubercles are larger, arranged in five longitudinal rows so that the tubercles of one row alternate in position on the segment with those of the adjacent row. The tubercles of the median row are located on the anterior margin of each segment.

The pleural lobes are flattened throughout their entire width. Each segment is continued laterally into a pair of long slender divergent spines which extend obliquely backward. A narrow well defined sulcus near the anterior margin divides each segment into a larger posterior portion and a smaller anterior portion; the former bears a row of five tubercles, the latter from seven to nine smaller ones. The base of each pleural spine bears a number of similar tubercles.

Dimensions.-Specimen No. 9233, median length of cephalon 3 mim., width between the genal angles $7 \mathrm{~mm}$., width between the ends of the genal spines $11.5 \mathrm{~mm}$., length of eight thoracic segments $4 \mathrm{~mm}$., width of thoracic axis $2.2 \mathrm{~mm}$.

Position and locality._Elgin member of the Maquoketa, Florenceville. Collected by Mary L. Calvin (Mrs. S. Calvin).

Remarks.-The incomplete type specimen described above represents all the known material of this species. The surface markings of $C$. maquoketensis stand in such striking contrast to the other Ordovician species of this genus that a comparison seems hardly necessary.

\section{Order PROPARIA}

\section{Family ENCRINURIDAE}

Encriaurus Pernodosus Slocom

Plate XVIII, figs. 4, 5, 6.

1913. Encrinurus pernodosus Slocom, Field Mus. Nat. Hist., Geol. Ser., vol. 4, p. 61, pl. XVI, figs. 5-7.

1916. Encrimurus pernodosus Slocom, Iowa Geol. Survey, vol. XXV, Ann. Rep. 1914, p. 209, pl. XVII, figs. 5-7.

“Type specimens Nos. P 17038 and P 16930 Field Museum.

Body ovate in outline, trilobation distinct, without genal or caudal spines. 
Cephalon sublunate in outline, anterior margin inflated, width more than twice the length. Glabella subhemispherical, width somewhat less than the length, slightly protruding beyond the anterior margin; three pairs of indistinct lateral glabella furrows define the lateral lobes; these furrows rapidly decrease in depth from the dorsal furrows and become obsolete among the tubercles; a well-defined furrow originates on the dorsal furrows about midway between the anterior lateral glabella furrows and the anterior marginal furrow and bends slightly forward in crossing the anterior lobe of the glabella; anterior glabella lobe large, comprising nearly half the glabella, lateral lobes quadrangular, decreasing rapidly in size posteriorly; occipital segment narrow, resembling the axial portion of one of the thoracic segments in size and form; occipital furrow narrow, angular, well-defined; dorsal furrows deep, angular, diverging somewhat from the occipital furrow to the anterior marginal furrow; cheeks subtriangular in outline, depressed conical in form, sloping gradually to the palpebral lobes; eyes small, pedunculate, holochroal; facial sutures originating at the genal angles, passing directly to the palpebral lobes, which they cross, thence obliquely forward, crossing the dorsal furrows and subparallel to the furrow crossing the glabella, until they meet the rostral plate, where they bend abruptly forward to the anterior margin; free cheeks large, more than twice the size of the fixed cheeks; marginal borders well-defined by the marginal furrows, those of the posterior margin narrow, those of the lateral margins wide, gradually narrowing to the anterior margin; genal angles rounded, ending in a large tubercle. Surface of the glabella covered with large rounded tubercles, that of the cheeks near the dorsal and lateral marginal furrows tubercular, other portions covered with elongated pits radiating from the eyes; surface of the occipital segment and marginal borders finely granulose. Hypostoma broadly elliptical, convex.

Thorax composed of eleven segments; axis convex, about the same width as the pleuræ; tapering slightly posteriorly, pleuræ curving regularly to the lateral margins; surface of the thoracic segments finely granulose, ornamented with indistinct nodes; these vary from two to four on the axis and one or two on each pleura; no pleural grooves.

Pygidium triangular, convex, width somewhat greater than the length, rounded posteriorly, no caudal spines. Axis convex, conical, occupying about one-third the anterior margin of the pygidium, with many annulations, which diminish in size and distinetness posteriorly so that the number visible depends to a great extent on the amount of abrasion to which the specimen 
has been subjected; most of the annulations bear two to four rounded nodes, having decided pits in their apices. Pleuræ composed of seven distinct ribs, which curve slightly upward and then downward and backward to the margins; each rib ornamented with two or more rather indistinct nodes near the dorsal furrows and with a prominent knoblike distal end.

Dimensions of the type specimen:

Length of cephalon $10 \mathrm{~mm}$.

Width of cephalon at genal angles................................17.5 mm.

Length of glabella exclusive of occipital segment ...... $8.4 \mathrm{~mm}$.

Width of glabella on anterior margin................... $8.0 \mathrm{~mm}$.

Width of glabella on occipital furrow.................. $5.0 \mathrm{~mm}$.

Entire length of body measured on a coiled specimen._32.0 mm.

Length of pygidium (Field Mus. No. P 16930) ......... $8.2 \mathrm{~mm}$.

Width of pygidium

Width of axis at anterior margin

The species is known from the holotype (Field Mus. No: P 17038) in which the cephalon, about two-thirds of the thorax and most of the pygidium are preserved, from five detached pygidia and from one specimen in which the entire pygidium is attached to all but the anterior segment of the thorax.

In general form and proportions the species here described resembles $E$. variolans Brongniart, from the Wenlock Limestone of England, but the tubercles are much larger, the transverse furrow on the glabella is missing and the annulations of the pygidia are fewer in number. $E$. sexcostatus Salter possesses the transverse furrow, but that seems to be about the only resemblance with this species.

Locality and horizon.-The holotype is from the top of the Lower Maquoketa beds at Bloomfield. The species has been found at a similar horizon at Clermont and Elgin, and at a somewhat lower horizon at Clermont." After Slocom 1916.

No additional material of this species has been found.

\section{Cybeloides towensis Slocom}

$$
\text { Plate XVIII, fig. } 1 .
$$

1913. Cybeloides iowensis Slocom, genotype, Field Mus. Nat. Hist., Geol. Ser., vol. 4, p. 64, pl. XVI, figs. 1-4.

1916. Cybeloides iowensis Slocom, Iowa Geol. Survey, vol. XXV, Ann. Rep. 1914, p 213, pl. XVII, figs. 1-4.

“Type specimens Nos. P 16631, 16633 and 17039 Field Museum. Body depressed convex, distinctly trilobed, outline, aside 
from the spines, subovate, tapering rather rapidly to a small pygidium. Surface finely granular with many more or less prominent rounded nodes.

Cephalon short, width nearly three times the length, outline sublunate with the anterior lateral margins inflated. Glabella convex, inflated anteriorly, somewhat longer than wide, widest across the lateral lobes; median lobe clavate, narrow at the occicipital furrow, gradually widening for about half its length then abruptly widening until its greatest width is reached, rounded in front; lateral lobes longitudinally oval; longitudinal glabella furrows originating in deep pits on the occipital furrow, converging slightly, then curving forward and outward; the positions of the lateral glabella furrows are indicated by three pits in the longitudinal furrows; occipital ring prominent, more elevated than any other part of the cephalon, wide between the glabella furrows, abruptly narrowing towards the dorsal furrows, bearing a large median node with a smaller one on each side of it; occipital furrow shallow and ill-defined in the median portion, deepened into pits near the dorsal furrows. Surface of the glabella finely granular with many prominent rounded nodes arranged in more or less uniform transverse rows; the two largest nodes are close together near the anterior margin and point forward. On the median line of the glabella just in front of a line connecting the anterior pair of glabella pits is a circular, well-marked pit. Cheeks large, depressed convex, not rising as high as the glabella, genal angles produced into long spines, which extend backward more than half the length of the thorax. Marginal borders convex; posterior marginal furrows narrow and deep, lateral marginal furrows not well-defined. The facial sutures originate on the lateral margin just in front of the genal angles, pass almost straight to the palpebral lobes, after crossing which they extend forward for a short distance, then curve abruptly toward the median line and again forward to the anterior margin. Eyes small, pedunculate and very prominent, situated on a line with the anterior pair of glabella pits near the dorsal furrows; a pair of ocular ridges connects the eyes with the anterior lobe of the glabella. Surface of the cheeks inside the marginal borders reticulated, or covered with rows of pits; surface of the marginal borders granular like the glabella, many nodes irregularly distributed over the cheeks; these nodes ayerage somewhat larger than those on the glabella; the larger ones are on the posterior margin and point backward instead of outward.

Thorax composed of twelve segments, rather rapidly tapering posteriorly, distinctly trilobed; axis convex, less than one-third 
the width of the thorax; the pleural lobes curve gently for about half their width and then more abruptly to the lateral margins. Each segment is divided unequally by a furrow extending nearly from one margin of the thorax to the other. The posterior portion, which is the wider, bears numerous nodes, four of which occur on the axis and two or more on each pleura. The nodes on the pleuræ are much larger than those on the axis and their location on different segments is not always uniform. The five anterior segments terminate at the lateral margins of the thorax, but the seven posterior ones are abruptly bent backward at the lateral thoracic margins and are produced into spines. The spines of the sixth segment extend more than one-third their length beyond the pygidium; the spines of the other segments are considerably shorter.

Pygidium small but too poorly preserved in the specimens at hand for a detailed description.

The dimensions of the type specimens are as follows:

Length of the holotype along the axis $23.6 \mathrm{~mm}$. Length of body, including pleural spines, $31.3 \mathrm{~mm}$.; width at genal angles $19.6 \mathrm{~mm}$.; length of cephalon, including genal spines, $16 \mathrm{~mm}$.; length of glabella $7.8 \mathrm{~mm}$.; width of anterior portion of glabella $4.7 \mathrm{~mm}$., across lateral lobes, $5.3 \mathrm{~mm}$.; length of thorax $12.8 \mathrm{~mm}$.

Width of paratype at genal angles $27.8 \mathrm{~mm}$. ; length of glabella $10.7 \mathrm{~mm}$.; width of posterior portion $8.0 \mathrm{~mm}$., across lateral lobes, $8.7 \mathrm{~mm}$.

This description is based upon the holotype (Field Mus. No. P 16631), a nearly complete specimen, a practically complete cephalon (Field Mus. No. P 17039), somewhat larger than the holotype, and a detached free cheek with eye (Field Mus. No. P 16633).

Localities and horizon.-The holotype was collected by the writer from the top of the Lower Maquoketa beds at Elgin, the two paratypes from a similar horizon at Bloomfield. More or less complete cranidia are not uncommon at a similar and somewhat lower horizon at Clermont." After Slocom 1916.

In the University collection there is one cranidium of $C$. iowensis, No. 9259, from the Elgin member of the Maquoketa at Dover Mills and Doctor Thomas found a well preserved nearly complete specimen, No. 9263, in the same horizon on the Leehy farm near Clermont. 


\section{Family CALYMENIDAE}

\section{CaLymene fayetrensis Slocom}

$$
\text { Plate XIX, figs. 4, 5, } 6 .
$$

1913. Calymene fayettensis Slocom, Field Museum of Natural History, Geology, vol. IV, p. 67, pl. 16, figs. 8-9. Lower Maquoketa shale, Clermont, Elgin, Bloomfield.

1916. Calymene fayettensis Slocom, Iowa Geol. Survey, vol. XXV, p. 216, pl. 17, figs. 8-9.

The general form and outline of this species is quite similar to the other members of this genus. The glabella is moderately convex and only slightly elevated above the cheeks; the width across the posterior glabellar lobes is somewhat less than the median length. The dorsal furrows are well defined throughout. The eyes are situated about opposite the second glabellar furrows. The axial segments of the thorax are arched gently forward and provided on either side with a rounded node adjacent to the dorsal furrow. The proximal third of each pleural segment of the thorax bears on the anterior margin an elongate triangular lobe the point of which is directed forward on the crest of the convexity when the body is rolled up. The axis of the pygidium is marked by seven annulations and each pleural lobe by five or more. The annulations of the latter are marked distally by a faint median groove. All parts of the surface are covered by fine papillæ and numerous small rounded tubercles.

For a detailed description see Slocom, op. cit., 1913.

This species is similar to $C$. senaria in many respects and was so referred until Slocom erected this new species. Only by a close comparison can certain differences between the two species be distinguished. In C. senaria the anterior lateral glabellar furrows are more distinct but the lateral nodes on each thoracic axial segment as well as the small rounded tubercles on the general surface are wanting. Slocom ${ }^{2}$ in comparing the two species states: "the glabella in C. senaria is shorter and more convex, the pleural segments of the pygidium do not have a longitudinal furrow.' On comparing the length of the glabellae with the

9 Slocom, op. cit., 1913, p. 68. 
median length of the cephala of twenty undoubted $C$. senaria from the Waynesville, Ohio, area the ratio is found to be as 8 to 12 and for eight $C$. fayettensis from Iowa the ratio is as 8 to 11.2. This small difference in length of glabella is of small specific value. All of the $C$. fayettensis at hand have the longitudinal furrow on the pleural segments of the pygidium but this character appears also to be common to $C$. senaria for out of twenty-five spécimens of the latter examined eleven had the furrows and fourteen were without them. Those specimens which do not show the furrows seem to be somewhat worn.

Position and localities.-Maquoketa shales, Elgin and Clermont members, at Clermont, Flgin, Dover Mills, Ossian and numerous other localities in northeast Iowa.

Cranidia of this species are fairly common but complete specimens are rare.

Calymene senaria, where it is mentioned in the various county reports dealing with the Ordovician, is here referred to C. fayettensis, except that mentioned for Pattersons Springs (Iowa Geol. Survey, vol. XV, p. 479) which is C. gracilis.

\section{Calymene gracilis Slocom \\ Plate XIX, figs. 7, 8.}

1913. Calymene gracilis Slocom, Field Museum of Natural History, Geology, vol. IV, p. 69, pl. 18, fig. 9. Limestone layers of the Upper Maquoketa beds at Patterson's Springs near Brainard, Iowa.

1916. Calymene gracilis Slocom, Iowa Geol. Survey, vol. XXV, p. 219, pl. 19, fig. 9. Horizon and locality same as preceding.

The following description is after Slocom 1913:

"Body small, in form and general proportions similar to other species of the genus. The surface of the test appears smooth to the naked eye but under a magnifier it appears very finely papillose.

Cephalon sublunate, width of the genal angles somewhat less than twice the length of the median line, about as 7 to 4 . Anterior border flat, projecting obliquely forward and upward, not recurved, separated from the glabella by a deep, narrow, marginal furrow. The dorsal furrows, in passing forward from the occi- 
pital ring, diverge slightly near the posterior glabellar lobes, then converge until they meet the anterior marginal furrow. Here the dorsal furrows become nearly obsolete on account of a large rounded node on each fixed cheek, opposite the anterior lobe of the glabella. Glabella convex, elevated above the cheeks, shorter than is usual in this genus, widest at the posterior lobes where the width is equal to the length, including the occipital ring, much narrower anteriorly: anterior lobe transverse, width less than one-third the length; first lateral lobes well defined, about the width of the anterior lobe and terminating about the same distance from the median line; second lateral lobes large and nodelike; posterior lateral lobes much larger, forming a pair of conspicuous nodes at the base of the glabella. Lateral furrows well defined but not crossing the glabella. The first pair transverse; second pair somewhat larger but bent slightly backward; posterior pair broader and deeper, curved backward towards but not reaching the occipital furrow. At about two-thirds of their length from the dorsal furrows they bifurcate and the shorter fork extends toward the median line of the glabella, forming a well-defined node between the second and posterior lobes. The facial sutures originate just in front of the genal angles, curve forward and inward over the palpebral lobes and thence forward to the anterior margin. Occipital ring prominent, slightly wider in the middle, separated from the rest of the glabella by a welldefined occipital furrow. Cheeks only moderately convex aside from the palpebral lobes, which are long for this genus and rise very abruptly from the dorsal furrows; lateral marginal borders wide and well rounded, posterior border much narrower; all are defined by deep marginal furrows.

Thorax known only by a few detached segments which indicate that it was narrow and elevated.

Pygidium subtriangular, terminating in a rounded obtuse angle, strongly elevated and trilobed. Axis convex, marked by six or seven annulations; it tapers gradually and is truncated posteriorly so that the dorsal furrows instead of meeting at a point posteriorly are joined by a short transverse furrow; the pleural lobes slope abruptly from the dorsal furrows to the margins; each lobe consists of five segments, faintly grooved on their distal portion; the segments merge into a smooth, undefined marginal border.

The type specimen is a perfect cranidium with the following dimensions: Length on median line $7: 8 \mathrm{~mm}$.; length including genal angles $9.0 \mathrm{~mm}$.; width $14.0 \mathrm{~mm}$.; length of glabella including occipital ring $5.4 \mathrm{~mm}$.; length of 'glabella without occipital 
ring $4.5 \mathrm{~mm}$.; width of glabella at anterior lobe $3.5 \mathrm{~mm}$.; width of glabella at posterior lobe $5.4 \mathrm{~mm}$. A detached pygidium gives the following measurements: Length $3.4 \mathrm{~mm}$.; width $6.4 \mathrm{~mm}$.; thickness 4.8 mm."

Position and locality.-Brainard member of the Maquoketa at Pattersons Springs near Brainard.

Remarks.-During the summer of 1921 the writer visited the type locality and collected numerous slabs of highly fossiliferous limestone immediately underlying the Niagaran limestone. Cranidia, pygidia and other parts of the body of $C$. gracilis are very common. Associated with these fragments there is a calymenid hypostoma which is here referred to this species since at this horizon no other Calymene is found to which this hypostoma could belong. Calymene gracilis can be readily distinguished from all other Calymene by its small size, the relatively high palpebral lobes and the node which is situated on each fixed cheek in apposition to the frontal lobe, causing the dorsal furrow to be obsolete in many specimens. The uppermost layers of the Maquoketa were examined in many places in northeastern Iowa but $(\because$ gracilis was found in the type locality only.

\section{Calymene mammillata Hall \\ Plate XIX, figs. 1, 2, 3.}

1861. Calymene mammillata Hall, Rep. Supt. Geol. Surv. Wisconsin, p. 50. In the shales above the Galena limestone, Maquoketa creek, 12 miles west of Dubuque, Iowa.

1862. Calymene mammillata Hall, Geol. Wisconsin, vol. 1, p. 432, figs. 1, 2 (no description).

The original description of this species by Hall is here copied.

"Form of the entire body unknown. Cephalic shield broadly semielliptical, the posterior margin nearly straight, the anterior border extended in front of the glabella in a broadly rounded, thickened projection, which is abruptly recurved at the margin, and marked on each side by a mammilliform tubercle about half way between the antero-lateral angle of the glabella and the edge of the border. The glabella is proportionally small, broad at base, rounded in front, lobed at the sides by three pairs of transverse furrows; the posterior lobes extend about one-third across the glabella, and are directed backwards, forming two rather 
large tubercles; the two anterior pairs are small, and extend but a short distance from the margin of the glabella. The centre of the glabella is prominent, the sides nearly parallel to the anterior angles, which are slightly extended laterally; occipital furrow distinct, bent forward in the middle.. Cheeks very prominent, giving great depth to the furrows which divide them from the glabella; the lateral borders thickened with a rounded margin. On the inside of the projecting border, in front of the glabella, there are two large rounded tubercles, which form a conspicuous feature.

Pygidium semielliptical, the central lobe or axis not very prominent, marked by seven annulations besides the terminal one, which is nearly as long (wide) as the three preceding, obtusely rounded posteriorly: the lateral lobes are broad, nearly twice the width of the central lobe at its junction with the last thoracic segment; marked by six broad flattened ribs, which become obsolete before reaching the margin; the anterior five are divided in the middle or on the outer half of their length, by a narrow sulcus.

Surface of the whole crust of the body, so far as seen, covered with fine rounded papillæ."

Remarks.-This trilobite is so distinctive that it is not likely to be mistaken for any other species of Calymene. The unusually large, broadly rounded, thickened, upward projecting brim in front of the glabella, the two mammilliform tubercles on the inside of the brim anterior to the dorsal furrows, the exceptionally deep dorsal furrows between the glabella and fixed cheeks, the small frontal lobe with its node-like projection on each anterolateral angle and the characteristic surface markings are features which distinguish this species from all other Calymene. The average median length of the cephalon is about $15 \mathrm{~mm}$., and the width across the genal angles is twice the length. The axis of the pygidium is well defined throughout, broadly rounded behind and bordered by the dorsal furrow, which widens into a broad shallow groove in the region of the sixth to the eighth segments:

Associated in the same beds with the cranidia and the pygidia of $C$. mammillata there is a calymenid hypostoma which, because of its association, is here tentatively referred to this species. The hypostoma is considerably longer than wide and the anterior third is abruptly expanded from the nearly straight or gently curved sides to form a semicircular itilargement with a recurved 
margin. The posterior part is produced into a short fork and the central area is broadly convex and bordered by a groove on each side.

Position and localities.-This species has been successively recorded from this same locality by Hall (op. cit.), James, Calvin and Bain, and Thomas. ${ }^{10}$ And the writer has collected numerous cranidia, pygidia and a hypostoma from here. Savage (Iowa Geol. Survey, vol. XVI, 1905, p. 601) reports a pygidium from the Maquoketa shale at Bellevue, Iowa, which he refers to this species. As far as now known $C$. mammillata has not been recorded from any localities outside of the state of Iowa ${ }^{11}$ and within the state it is limited in its occurrence to the Maquoketa shales. The type specimens are now in the American Museum of Natural History and according to Whitfield (Bull. Am. Mus. Nat. Hist., vol. XI, pt. I, 1898, p. 68) they consist of " a large, partly exfoliated cranidium and a pygidium, imbedded separately" and "four unfigured types in the series." Their museum catalogue number is 1408 .

\section{Calymene callicephala Green}

1832. Calymene callicephala Green, Mon. Tril. North America, p. 30 , cast 2.

This species has been reported from the Maquoketa shales at Graf, Iowa, by Joseph F. James. ${ }^{12}$ Other geologists who have collected in this locality either before or since 1890 have failed to note the occurrence of $C$. callicephala. There seems to be a good deal of doubt concerning the status of this species. Bassler ${ }^{13}$ suggests that the specific name callicephala be abandoned since Green's cast of the type can not be identified with any of the species of Calymene. In all probability therefore the $C$. callicephala of James is a C. mammillata.

10 James, American Geologist, vol. 5, 1890, p. 353. Calvin and Bain, Iowa Geol. Survey, vol. $\mathrm{X}$, p. 435. Thomas, Iowa Acad. Sci., Proo., vol. XXI, p. 229.

11 James (op. cit., 1890, p. 353) reports $O$. mammillata from Wisconsin without, however, giving any locality. It is possible that this is an error. In the Geology of Wisconsin, Hall lists this species and gives the only figures which have ever been published of the type but no locality is mentioned. From this record James may have assumed that the species occurs in Wisconsin.

12 James, Am. Grol, vol. V, p. 353, 1890.

13 Bassler, Bibliographic Index of American Ordovician and Silurian Fossils: vol. I, p. 166. 


\section{Family CHEIRURIDAE}

\section{Ceraurus pleurexanthrmus Green}

Plate XIX, fig. 9.

1832. Ceraurus pleurexanthemus Green, Mo. Amer. Jour. Geol., vol. I, p. 560, pl. 4, fig. 10.

1847. Ceraurus pleurexanthemus Hall, Pal. New York, vol. I, p. 242, pl. 65, figs. 1 a-1 n except $1 \mathrm{~d}, 1 \mathrm{~h}, 1 \mathrm{i}, 1 \mathrm{~m}$.

1847. Ceraurus pleurexanthemus S. A. Miller, Cincinnati Quar. Jour. Sci., vol. I, p. 132.

Thus far this species is but poorly represented in the trilobite fauna of this state. Slocom, in his very careful study of the trilobites of Fayette county, did not ob-

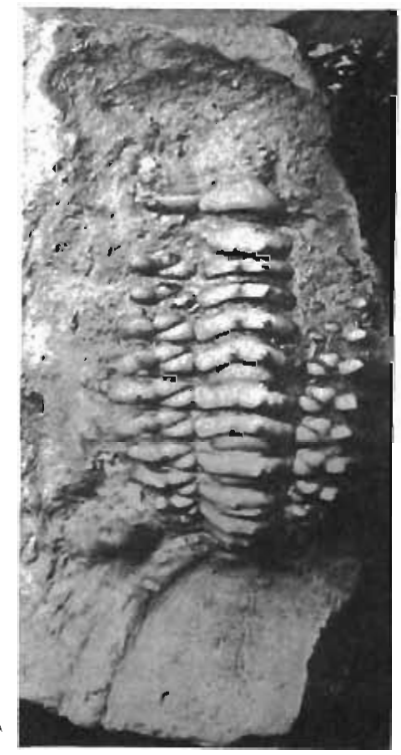

FIG. 26.-A large and well preserved specimen of Cer from Boyle's quarry near from Boyle's quarry near
McGregor. No. 9289 . Col. lected by Miss Florence $\mathrm{S}$. Chapin. serve this species there. The writer met with a similar experience. But the Platteville limestone along Sny Magill creek, Clayton county, yielded one well preserved but incomplete head, No. 9180, showing nearly all the specific characters of the cephalon. The glabella is clavate, moderately convex, rising to the height of the strongly arched occipital segment. Three pairs of short glabella lateral furrows are present on each side, the posterior pair opening into the occipital groove and delimiting a pair of small circular basal lobes. The eyes are situated somewhat closer to the dorsal furrows than to the posterior margin of the cephalon. The genal angles are produced into long curved flaring genal spines. The surface of the glabella and free cheeks is irregularly covered with small tubercles of different sizes. The marginal border and the genal spines are finely granulose.

Position and localities.-Number 9180, Platteville limestone, about three and one-half miles southwest of McGregor, along Sny 
Magill ereek, Clayton county. This species apparently ranges throughout the Platteville of Iowa.

Since the above was written a nearly complete specimen was found in the Platteville limestone at Boyle's quarry near McGregor by Miss Florence S. Chapin. This specimen was briefly described by Dr. A. O. Thomas at the annual meeting of the Iowa Academy of Science at Cedar Falls, May, 1925. Museum No. 9289. See text figure 26 .

\section{Ceraurus milliganus Miller and Gurley}

$$
\text { Plate XX, fig. } 7 .
$$

1894. Ceraurus milleranus Miller and Gurley, Bull. III, Illinois St. Mus. Nat. Hist., p. 80, pl. 8, fig. 10.

1913. Ceraurus milleranus Slocom, Field Mus. Nat. Hist., Geol. ser., vol. 4, p. 71, pl. 17, figs. 1-3.

1916. Ceraurus milleranus Slocom, Iowa Geol. Survey, vol. XXV, Ann. Rep. 1914, p. 221, pl. XVIII, figures 1-3.

"Type specimen No. 6062 University of Chicago.

General outline of the carapace, exclusive of the spines, subovate, abruptly narrowed posteriorly ; moderately convex, trilobation distinet.

Cephalon semielliptical, width nearly three times the length; dorsal furrows well marked. Glabella convex, narrower than the cheeks at the occipital ring, gradually widening anteriorly until its width about equals its length, abruptly bent downward at the frontal margin; anterior lobe constituting about one-third the length of the glabella; the three pairs of lateral furrows are short and about equidistant, forming three pairs of small convex lateral lobes; the two anterior pairs of furrows extend slightly forward, but the posterior pair is transverse for a part of its course and then bends abruptly backward until it meets the occipital furrow isolating the posterior lateral lobes. Occipital segment arched upward, higher than the anterior portion of the glabella, greatest height at the posterior margin, sloping gradually into the occipital furrow. This furrow is narrow and deep behind the posterior lateral glabella lobes but wider and shallow in its median portion. Cheeks convex with well-defined rounded marginal borders, posterior angle produced into spines, which point backward; eyes prominent, globular, placed near the center of the cheeks; the palpebral lobes bear a pit near the base on the side nearest to the dorsal furrows; the facial sutures originate on the 
lateral margins about in line with the occipital furrow, curve forward and inward to the palpebral lobes, which they traverse, thence pass forward with a sigmoid curve to the anterior margin of the cephalon.

Thorax composed of ten segments; axis convex, about the same width as the pleurs; pleurre flattened for one-third to one-half their width from the dorsal furrows, then bent downward and backward, tapering to a point; each pleural segment is ornamented with a prominent tubercle situated near the point where the pleuræ curve downward; an angular furrow originates on the anterior margin of each pleural segment at the dorsal furrow and crosses it obliquely, reaching the posterior margin behind the tubercle; dorsal furrows distinct, nearly parallel from the first to the eighth thoracic segment, then converging posteriorly.

Pygidium short, much narrower than the posterior segment of the thorax, consisting of three segments: the anterior segment bears a pair of stout spines, which extend posteriorly with the points somewhat converging; axis undefined.

Surface of the cephalon, within the marginal borders, covered with irregularly placed tubercles; on the cheeks the tubercles are somewhat farther apart and the interspaces are pitted; the marginal borders and genal spines are finely granulose; two or more conical tubercles are situated on the posterior borders of the cheeks; the entire thorax is finely granulose, as is also the pygidium, but the granulations are more conspicuous on the caudal spines.

Measurements of the type are as follows:

Length on median line. $28.7 \mathrm{~mm}$.

Tength including caudal spines $35.4 \mathrm{~mm}$.

Width at genal angles. $21.6 \mathrm{~mm}$.

Width at points of genal spines. $23.6 \mathrm{~mm}$.

Length of cephalon including genal spines._.......... $11.5 \mathrm{~mm}$.

Length of glabella. $8.0 \mathrm{~mm}$.

Width of posterior lobes of glabella. $6.0 \mathrm{~mm}$.

Width of anterior lobe of glabella $7.5 \mathrm{~mm}$.

Width of pygidium $7.4 \mathrm{~mm}$.

Length of pygidium. $2.7 \mathrm{~mm}$.

The above description is based on the type specimen from Cincinnati, Ohio, No. 6062 of the paleontological collection of the University of Chicago. The species is known to the writer from Fayette county by twelve more or less complete cephalons and two pygidia. These agree with the type except that in the type the genal spines are somewhat shorter, the tubercles on the posterior border are less conspicuous and the longitudinal 
curve of the glabella is somewhat more abrupt in front, making its anterior lobe appear shorter in dorsal view. This last feature may be due to distortion.

C. milleranus is distinguished from $C$. pleurexanthemus by its proportionally shorter cephalon, its less flaring genal spines, and by its being globular and situated about equidistant from the dorsal furrows and from the posterior margin of the cephalon. The eyes of $C$. pleurexanthemus are conical and nearer the dorsal furrows. Further, the spines of the pygidium in C. milleranus converge at their points instead of diverging as in $C$. pleurexanthemus.

Locality and horizon.-Lower Maquoketa shales of Clermont and Elgin." After Slocom 1916.

Extended collecting by the author in Fayette county localities resulted in the finding of a few incomplete cephala, Nos. 9198 and 9204, and other fragments which undoubtedly belong to this species. They contribute nothing new. No trace of this species was encountered outside of the areas reported by Slocom except at Hover Mills and McGregor. In the last mentioned locality the species is found in the Platteville limestone.

\section{Ceraurus elginfansis Slocom}

Plate XIX, fig. 10.

1913. Ceraurus elginensis Slocom, Field Mus. Nat. Hist., Geol. Ser., vol. 4, p. 73, pl. XVII, figs. 4, 5:

1916. Ceraurus elginensis Slocom, Iowa Geol. Survey, vol. XXV, Ann. Rep. 1914, p. 224, pl. XVIII, figs. 4, 5.

“Type specimens Nos. P. 16630A, 16630B, 17030 Field Museum.

Cephalon sublunate, width more than three times the length, anterior lateral margins arcuate, posterior margin transverse in the median portion, gently bent backward near the genal angles. Glabella convex, clavate; less than half the width of the cheeks at its posterior margin but gradually widening anteriorly until its width nearly equals its length; anterior lobe constituting about one-fourth the entire length of the glabella; three pairs of lateral furrows rather short, well defined, defining three pairs of convex lateral lobes, diminishing in size posteriorly; the two anterior pairs of furrows are transverse, the posterior pair are transverse for part of their length, then bent backward until they join the occipital furrow, isolating the posterior lobes; occipital segment elevated at the posterior margin, sloping into the oc- 
cipital furrow; occipital furrow shallow, concave in the median portion, narrower, deeper and bent backward behind the glabella lobes; dorsal furrows deep, angular, forming deep angular pits where they merge into the marginal furrows; cheeks large, convex, posterior angles produced into long, stout spines, flattened anteriorly and pointing almost directly backward; palpebral lobes elongated, large for the genus, placed well forward, about midway between the dorsal furrows and the lateral margins but nearer the posterior margins than the dorsal furrows. Near the base of each lobe on the side toward the dorsal furrow is situated a decided pit; an indistinct furrow extends from this pit to the crest of the lobes; the ocular ridges extend from the anterior angle of the palpebral lobes to the pit in the dorsal furrows; the facial sutures originate on the lateral margins about in line with the posterior marginal furrow, curve forward and inward to the palpebral lobes, which they traverse, then forward to the anterior margin, which they reach in front of the glabella; marginal borders prominent, defined by shallow furrows; the posterior furrows curve into the lateral furrows just within the genal angles; free cheeks small, less than one-third the size of the fixed cheeks. The surface of the glabella, with the exception of the occipital segment and the cheeks, is covered with more or less regularly distributed rounded tubercles; a larger, more conical tubercle is situated on each fixed cheek, just in front of the posterior furrow, at about one-third the distance from the dorsal furrow to the genal angle. A row of spinelike tubercles traverses the posterior marginal borders of the cheeks, and similar tubercles are distributed over the flattened portions of the genal spines, gradually diminishing in size posteriorly until they become obsolete.

Thorax not known.

Pygidium transversely subelliptical in outline, aside from the spines length less than half the width; composed of three segments, the extremities of the anterior segment produced into long, stout, flattened spines, which curve outward and backward; second and third segments much smaller; axis not well defined. The surface of the caudal spines is covered with sharp conical tubercles similar to those on the genal spines. The pygidium above described was not associated with the cephalons but came from the same horizon at Bloomfield. Its size and the form and ornamentation of the spines are such as might accompany these cephalons and no other cephalons have been observed to which this pygidium could well be referred. 


\begin{tabular}{|c|c|c|}
\hline Measurements & P $16630 A$ & P $16630 \mathrm{~B}$ \\
\hline 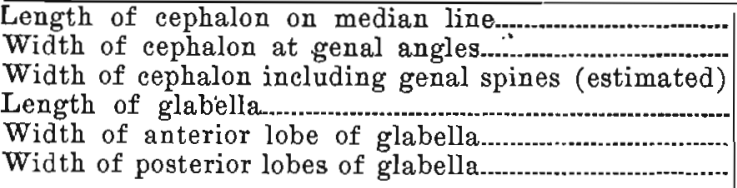 & $\begin{array}{r}13.7 \mathrm{~mm} . \\
38.5 \mathrm{~mm} . \\
40.0 \mathrm{~mm} \text {. } \\
13.0 \mathrm{~mm} \text {. } \\
11.5 \mathrm{~mm} \text {. } \\
8.8 \mathrm{~mm} .\end{array}$ & $\begin{aligned} 12.3 \mathrm{~mm} . \\
36.3 \mathrm{~mm} . \\
38.0 \mathrm{~mm} . \\
11.0 \mathrm{~mm} . \\
9.6 \mathrm{~mm} . \\
6.7 \mathrm{~mm} .\end{aligned}$ \\
\hline & \multicolumn{2}{|c|}{ P 17030} \\
\hline $\begin{array}{l}\text { Width of pygidium } \\
\text { Length of pygidium. } \\
\text { Length of caudal spines (estimated) }\end{array}$ & \multicolumn{2}{|c|}{$\begin{aligned} 10.7 \mathrm{~mm} . \\
5.5 \mathrm{~mm} \text {. } \\
20.0 \mathrm{~mm} \text {. }\end{aligned}$} \\
\hline
\end{tabular}

C. elginensis differs from all other species known to the writer in having extremely long genal spines with spinelike tubercles on their flattened portion. It is also distinguished from C. milleranus and C. pleurexanthemus by having the eyes farther apart. It is most nearly related to C. dentatus Raymond and Barton, but the ocular ridges are not present in that species and the eyes are not so far forward.

Locality and horizon.-The species is known to the writer from two cephalons from the top of the Jower Maquoketa beds at Elgin, and a pygidium, which is referred with sone doubt, from the same horizon at Bloomfield. Fragments of genal spines and other parts of the test which, from their size and ornamentation, appear to belong to this species, have been observed on slabs from the Upper Maquoketa beds at Pattersons Springs." After Slocom 1916.

\section{Ceraurus savagei, n.s. \\ Plate XXV, fig. 1.}

Description.-Cephalon very broad, moderately convex, narrowly elongate-oval to subelliptical; the length is to the width as 3 is to 8 . The genal angles are rounded and without spines. The glabella is prominent, broadly convex, expanding forward at the rate of $1 \mathrm{~mm}$. for every $3.8 \mathrm{~mm}$; the anterior end is broadly rounded, slightly emarginate medially, and bordered by a narrow marginal rim. There are three pairs of short lateral glabellar lobes; the first and second pairs are nearly equal in size and are delimited by short lateral groaves which are very deep at the dorsal furrows but are obsolete a short distance on the glabella; the third or basal glabellar lobes are isolated and quadrangular 
in outline. They are separated from the median glabellar lobes by short transverse furrows which terminate in a pitlike depression and connect with short longitudinal furrows which in turn are continuous with the occipital groove. The distance between the basal glabellar lobes is equal to a little more than two and onehalf times the width of one basal lobe. The occipital segment is strongly arched but incompletely preserved, the center having. been worn away. The occipital furrow is distinct but very shallow at the base of the glabella, more sharply defined at the basal lobes and somewhat larger laterally upon the fixed cheeks; a short distance within the rounded genal angles it turns abruptly forward. The fixed cheeks are large, most convex at the eyes but not attaining to the height of the glabella. The eyes of this specimen are missing but the ocular sinuses extend much closer to the posterior margin of the cephalon than to the dorsal furrows. The posterior margin of the fixed cheeks describes an irregular curve which has a general forward trend toward the genal angles where it curves more sharply forward.

The surface of the glabella is covered with numerous small tubercles. Between the eyes and the dorsal furrows the fixed cheeks bear numerous pits and tubercles but distally near the genal angles the tubercles become coarser and the pits are wanting. The posterior margin of each fixed cheek bears two pairs of tubercles of unequal size; the smaller pair is located near the genal angles, the larger pair near the dorsal furrows and the area between them is smooth.

Dimensions.-Specimen No. 9183 is $15 \cdot \mathrm{mm}$. long and $38 \mathrm{~mm}$. wide; the length of the glabella is $11.4 \mathrm{~mm}$. and the greatest width anteriorly is $11.4 \mathrm{~mm}$. ; the width across the basal glabellar lobes is $9 \mathrm{~mm}$.

Free cheeks, eyes, thorax and pygidium unknown.

Position and locality.-Number 9183, Elgin member of the Maquoketa, Dover Mills. Collected by the writer.

Remarks.-The cranidium above described represents all the material of this species in the University collection. The absence of genal spines differentiates it from all existing species of Ceraurus except C. misneri Foerste, which shares this same character. The latter differs, however, from ours in having a much 
more abruptly expanding glabella and in having the eyes approximately equidistant from the dorsal furrows and from the posterior margin of the cephalon whereas in C. savagei they are decidedly closer to the posterior margin of the cephalon than they are to the dorsal furrows. The position of the eyes is similar to that of $C$. dentatus Raymond and Barton, from which it differs in the absence of genal spines as well as in its much smaller size.

The absence of spines is a striking character but not unique since they are absent also in C. misneri mentioned above. As a rule the distal ends of the fixed cheeks of ceraurids tend to thicken for the support of the genal spines but in the holotype this margin is very thin and that of the two extremities has a similar contour, indicating that if genal spines ever were present it is scarcely possible that they could have broken away.without leaving a trace on one or the other of the genal angles.

When it was collected the left fixed cheek was covered by a thick but soft matrix. This was removed with considerable care and no trace of a spine was observed although it was confidently expected. Therefore the writer feels fully convinced that this is another rare species without genal spines.

In the "Key to American Species of Ceraurus", ${ }^{14}$ C. savagei would belong in group $\mathrm{B}$, division $\mathrm{c}$, but with glabella expanding less abruptly forward.

The species is dedicated to Dr. Thomas E. Savage of the University of Illinois, formerly Assistant State Geologist of Iowa and author of "The Geology of Fayette County."

Ceraurus herrmanni n.s.

Plate XIX, figs. 11-15.

Description-Thorax depressed convex and composed of eleven segments. The sides are broadly rounded, converging abruptly near the posterior end. The axis is moderately convex and bordered by shallow but well defined dorsal furrows. Each segment is arched slightly forward and separated from the adjacent segment by a broad transverse groove. Along the dorsal furrow 14. Perey E. Raymond and Donald C. Barton, A Revision of the.American Species of Ceraurus:
Bull. Mus. Comp. Zool., Harvard College, vol. LIV, no. 20, p. 527 . 
each axial segment is somewhat thickened. The amount of thickening increases posteriorly, having the appearance of a discontinuous ridge. The axis is about four-fifths the width of the pleura. No tubercles are present on the axis.

The pleural lobes are depressed convex and divided into a free outer non-articulating portion and an inner nodose articulating portion. The articulating part of each segment is divided into two convex triangular elongate nodes by a narrow deep diagonal furrow which begins in front at the dorsal furrow and passes outward and backward, ending at the fulcral fold. In the center of each pleura, along a line dividing the free from the fixed portion, there is a less prominent circular node separated from the outer triangular node by a shallow depression directed inward from front to back: In front of each of these tubercles there is a well developed elongate nodelike fulcral process. The free outer portion of each segment is flattened, relatively smooth, bent downward and backward, ending in a point.

The pygidium is composed of four anchylosed segments. The axis is well defined, bearing four transverse annulations. The first is curved forward and constricted medially, bearing a depressed lobe in the constricted portion. The fourth segment is represented by a rectangular nodelike process. The first pleural segment gives rise to a pair of long flattened spines which diverge posteriorly for about one-half their length, thence converge slightly to the end. The second and third segments each give rise to a pair of short blunt spines, and the post-axial area gixes rise to a short triangular median spine making in all five short terminal spines within the great spines. At the proximal end of the great spines, adjacent to the dorsal furrows there is a pair of nodes; the anterior of these is about as large as the inner node on the pleura of the last thoracic segment; the posterior node is smaller and more elongate. The second and third pleural annulations are directed obliquely backward so as to appear trapezoidal with the second and third axial segments.

Dimensions.-Length from groove between first and second thoracic segment to median pygidial spine $63 \mathrm{~mm}$., greatest width $60 \mathrm{~mm}$., median length of pygidium $13 \mathrm{~mm}$., total length of same $45 \mathrm{~mm}$. 
Position and locality.-Platteville limestone near mouth of Catfish creek, Dubuque. Collected by Mr. Richard Herrmann.

Remarks.-This species is quite similar to Ceraurus dentatus

Raymond and Barton. Unfortunately, however, the cephalon is unknown so that a complete comparison is impossible. Our specimen differs from $C$. dentatus in the following characters: 1 , The great spines are decidedly flattened and not rounded as in $C$. dentatus. This flattening appears to have been the original condition rather than an accident of preservation, since nearby nodes on the pleuræ are not flattened. 2, The distal portions of the great spines curve inward and not outward. 3, The posterior margin of the pygidium is less rounded, a line joining the tips of the small spines being nearly straight whereas in $C$. dentatus it is noticeably curved. 4, The pygidium of $C$. herrmanni is proportionally longer exclusive of great spines. 5, The axis of the pygidium tapers more abruptly between the first and third annulations.

Should a cephalon be found identical with that of $C$. dentatus our species probably would need to be referred to it.

Ceraurus herrmanni is of special interest because of its unusually large size, which exceeds that of the type of $C$. dentatus. The bifurcation of the left great spine on the pygidium is probably an acquired abnormality peculiar to this specimen. Similar bifid spines have been recorded for two or three other specimens of trilobites.

A large hypostoma, found in the Platteville limestone about three and a half miles south of McGregor, is here referred to $C$. herrmanni with some doubt. And several ceraurid free cheeks and cranidia from the same position and horizon as the hypostoma are similarly referred to $C$. hermanni because of their large size. See Plate XIX, figs. 13, 14, 15.

The type specimen was kindly loaned for study by the finder, Mr. Richard Herrmann of Dubuque, in whose museum the specimen now is. The writer takes pleasure in naming this species in honor of Mr. Herrmann.

$$
\begin{gathered}
\text { Ceraurinus ICarus (Billings) } \\
\text { Plate XX, figs. 10-13. }
\end{gathered}
$$

1860. Cheirurus icarus Billings, Can. Nat. and Geol., vol. 5, p. 67, fig. 2. 
1873. Ceraurus icarus Meek, Pal. Ohio, vol. I, p. 162, pl. 14, figs. 11a-c.

1889. Ceraurus meekanus S. A. Miller, N. Am. Geol.and Pal., p. 537.

1913. Eccoptochile meekanus Slocom, Field Mus. Nat. Hist., Geol. Ser., vol. 4, p. 75, pl. XNII, figs. 6-9.

1916. Ceraurinus icarus Slocom, Iowa Geol. Survey, vol. XXV, Ann. Rep. 1914, p. 227, pl. XVIII, figs. 6-9.

"Body subovate in outline, moderately convex, distinctly trilobed. Surface smooth to the naked eye but under a magnifier the cephalon appears finely granulose:

Cephalon subsemicircular, somewhat flattened anteriorly, genal angles produced into short spines, posterior margin nearly straight until it merges into the genal spines, where it is bent nearly at right angles. Glabella subquadrate, rounded in front, length in front of the occipital furrow about equal to the width, depressed convex. Anterior lobe of the glabella transversely oval, about twice as wide as long, lateral lobes nearly transverse and about equal in size. Glabella furrows distinct, length about onethird the width of the glabella, anterior pair bent backward; middle pair nearly at right angles to the axis of the glabella; posterior pair similar to the middle pair for most of the length but having the inner ends abruptly bent backward until they meet the occipital furrow, isolating the posterior glabella lobes; occipital segment arched upward somewhat higher than the rest of the glabella, wider in the median portion, tapering towards the dorsal furrows; occipital furrow deep and narrow, arched forward. Dorsal furrows deep and narrow, diverging slightly at the posterior margin of the cephalon, thence passing to the front of the glabella, which they surround, leaving a narrow anterior border. In each furrow just in front of the anterior glabella furrow is a distinct pit. Cheeks Iarge, sloping anteriorly and laterally from the eyes; posterior cheek furrows narrow; near the genal angles they meet the lateral furrows, which are wider and extend forward parallel to the margins until they meet the dorsal furrows; marginal borders somewhat concave on account of shallow marginal furrows, which originate on the genal spines. Eyes of moderate size, situated opposite the second glabella furrows, visual surface sublunate, palpebral lobes moderately prominent, approaching in height that of the glabella. The facial sutures originate a short distance in front of the genal angles, curve obliquely forward, then abruptly inward to the posterior angles of the eyes, follow the inner margin of the eyes and again for- 
ward with a broad curve, cutting the anterior margin of the cephalon in front of the glabella.

Thorax somewhat longer than wide, consisting of eleven segments, distinctly trilobed. Axis narrower than the pleuræ, regularly arched upward. Pleural lobes flattened for about one-third their width, thence abruptly curved to their lateral margins; each segment marked by a deep groove across the axis; another smaller groove originates on the anterior margin of each pleura near the dorsal furrows and crosses the pleura obliquely; on the anterior margin of each pleura, near the point where the pleura is bent downward, a still smaller groove defines a low oblong node which points forward, not upward. The segments are nearly transverse across the axis and about half the length of the pleurie; their distal portions curve gently backward to the falcate extremities.

Pygidium small, transversely subelliptical, width more than twice the length, posterior curve much flattened. Axis small with three well defined annulations. Two shallow pits occur just back of the termination of the axis. Pleural lobes large, composed of three segments which are produced posteriorly into flattened spines. The anterior pair is the largest; carinate on top, strongly curved backward and obtusely rounded at the extremities; the other two pairs decrease in size inward and are more pointed.

In my previous paper I referred these forms to Eccoptochile? meekanus S. A. Miller, with a footnote stating that Barton had a paper in press in which he created a new genus to which this species should be referred. My judgment in using Miller's species was based upon a rather incomplete description and figure of the Canadian species, which led me to believe that the two forms were distinct. Dr. Raymond has since informed me that, after comparing the Canadian specimens with those from the Mississippi Valley, he considers them to be identical, so that they are here referred to $C$. icarus Billings.

Locality and horizon.-The specimens here described are from the Lower Maquoketa beds, Clermont." After Slocom 1916.

Professor A. O. Thomas and the author found a number of cephala and a nearly complete specimen in the Lower Maquoketa in the vicinity of Clermont but the material is rare and usually fragmentary. Number 9243 is a cranidium from section 19, Clermont township. Numbers 9244, the left half of a specimen, and 9245, a nearly complete specimen, were collected by Professor Thomas on the Patrick Leehy farm near Clermont. A number of 
years ago Professor Calvin collected two nearly complete specimens, Nos. 9169 and 9170, at Clermont.

\section{Sphanrocorypee Maquoketensis Slocom}

$$
\text { Plate XX, figs. 4-6. }
$$

1913. Sphaerocoryphe maquoketensis Slocom, Field Mus. Nat. Hist., Geol. Ser., vol. 4, p. 77, pl. XV, figs. 1-4.

1916. Sphaerocoryphe maquoketensis Slocom, Iowa Geol. Survey, vol. XXV, Ann. Rep. 1914, p. 229, pl. XVI, figs. 1-4.

“Type specimens Nos. P 11152A, 11152B, 16954 and 17051 Field M[useum.

Cephalon sublunate in outline, convex, distinctly trilobed; anterior margin truncated; posterior margin nearly transverse. Glabella very prominent, anterior lobe globular, produced beyond the anterior margin, comprising fully three-fourths the bulk of the glabella; a single pair of shallow, transverse, lateral furrows meets just behind the lateral lobe of the glabella and separates it from a pair of indistinct lateral lobes; occipital segment arched slightly forward, its posterior margin abruptly elevated, surface sloping into the furrow; occipital furrow shallow, not well-defined except at its extremities. Dorsal furrows well defined, much wider and deeper at the junctures with the occipital and glabella furrows, diverging somewhat in passing forward from the posterior margin of the cephalon until near the anterior margin where they abruptly converge until they meet, forming the anterior marginal furrow; cheeks depressed convex, greatest elevation at the palpebral lobes, which are situated about midway between the posterior and anterior margins and one-third the distance from the dorsal furrows to the genal angles; antero-lateral margins of the cheeks forming an elongate sigmoid curve; free cheeks triangular, small, less than one-half the size of the fixed cheeks; eyes large, prominent, globular; the facial sutures originate on the lateral margins well in front of the genal angles, pass inward and slightly backward over the palpebra! Iobes. thence forward to the anterior margin; the genal angles merge into stout, recurved spines; the posterior marginal furrows are continuations of the occipital furrow but narrower and deeper; they terminate abruptly before the genal angles are reached; a deep elongate pit on each fixed cheek and a longer, shallower one on sach free heek represent the lateral marginal furrows.

Thorax not observed.

Pygidium small, subtrianglar in outline, aside from the spines; 
not distinctly trilobed, composed of three segments; the first of these has its extremities produced into long, diverging, slightly recurved spines; margin entire, with its ventral surface forming a thick doublure.

Surface of the globular portion of the glabella pustulose; pustules rounded, larger near the transverse glabella furrow and gradually diminishing in size anteriorly; balance of cephalon smooth or finely granulose; surface of pygidium pustulose, pustules more prominent on the spines.

\begin{tabular}{|c|c|c|}
\hline - Measurements of cephalon & $\begin{array}{l}\text { Holotype } \\
\text { P } 11152 \mathrm{~A}\end{array}$ & $\mathrm{P} 11152 \mathrm{~B}$ \\
\hline $\begin{array}{l}\text { Length on median line from posterior to anterior } \\
\text { margins }\end{array}$ & $4.6 \mathrm{~mm}$. & \\
\hline $\begin{array}{l}\text { Length from posterior margin to front of glabella...... } \\
\text { Length from front of glabella to points of spines..... }\end{array}$ & $\begin{array}{rl}7.4 \mathrm{~mm} & \mathrm{~mm} \\
13.0 \mathrm{~mm}\end{array}$ & $10.4 \mathrm{~mm}$. \\
\hline Length of anterior lobe of glabella & $5.0 \mathrm{~mm}$ & $7.7 \mathrm{~mm}$. \\
\hline Width of anterior lobe of glabella......... & $4.7 \mathrm{~mm}$. & $7.5 \mathrm{~mm}$. \\
\hline Width of cephalon at genal angles... & $10.2 \mathrm{~mm}$. & $14.6 \mathrm{~mm}$. \\
\hline Width of cephalon at points of spines. & $15.8 \mathrm{~mm}$. & \\
\hline 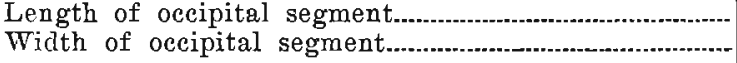 & $\begin{array}{l}2.3 \mathrm{~mm} . \\
\text { t.0 } \mathrm{mm} .\end{array}$ & $\begin{array}{l}3.3 \mathrm{~mm} . \\
1.2 \mathrm{~mm} .\end{array}$ \\
\hline Measurements of pygidium & P 16954 & P 17051 \\
\hline $\begin{array}{l}\text { Width of anterior margin.. } \\
\text { Length on median line...... } \\
\text { Length including spines... }\end{array}$ & $\begin{array}{l}3.4 \mathrm{~mm} . \\
1.5 \mathrm{~mm} . \\
4.2 \mathrm{~mm} .\end{array}$ & $\begin{aligned} 6.7 \mathrm{~mm} . \\
3.2 \mathrm{~mm} . \\
10.3 \mathrm{~mm} .\end{aligned}$ \\
\hline
\end{tabular}

This species is the most abundant trilobite in the shales of the Lower Maquoketa beds, but a great majority of the individuals are represented only by the globular portion of the glabella. They range in size from $2.5 \mathrm{~mm}$. to $7.5 \mathrm{~mm}$. in diameter. The writer was fortunate enough to obtain about twenty more or less complete cephalons and three pygidia. No thorax has been observed that can be referred to this species so that it is not certain that these pygidia belong to the cephalons, yet from their form and the conditions under which they were collected, there is little doubt that they belong to this species.

S. maquoketensis differs from all previously described species in possessing large pits in place of the lateral marginal furrows. It resembles $S$. granudata Angelin in the form of the marginal outline, but in $S$. maquoketensis the cephalon is longer in proportion to the width and the pustules on the glabella are finer. $S$. salteri Billings is from a similar horizon, but in $S$. salteri the width of the glabella at its posterior margin is three-fourths of its greatest width, and it has tubercles at the juncture of the occipital and dorsal furrows; in S. maquoketensis the glabella is 
twice as wide anteriorly as posteriorly and the tubercles are wanting.

Localities and horizons.-Abundant in the top layers and somewhat less so in the middle layers of the Lower Maquoketa shales of Clermont, Elgin, and Bloomfield.' After Slocom 1916.

As has been stated above by Slocom, fragments, principally parts of the head of this species, are exceedingly common in the Lower Maquoketa shales of Fayette county. But a complete specimen has not been found. Number 9246, a lot of two dozen heads, was collected from the gutters along the roadside between the north end of sections 23 and 24, Springfield township, Winneshiek county. Numbers 9247 and 9249 are from the Patrick Leehy farm near Clermont. Number 9248 was collected by Doctor Thomas in 'Ectenaspis Hollow' near Clermont. Number 9208 is the metatype collected by A. W. Slocom at Clermont.

\section{Family PHACOPIDAE \\ Pterygometopus Fredricki Slocom}

Plate XX, figs. 1-3.

1913. Pterygometopus fredricli Slocom, Field Mus. Nat. Hist., Geol. Ser., vol. 4, p. 79, pl. XVIIT, figs. 1-5.

1916. Pterygometopus fredricki Slocom, Towa Geol. Survey, vol. XXV, Ann. Rep. 1914, p. 232, pl. XIX, figs. 1-5.

"Type specimen No. P 17024 Field Museum.

Test elongate-ovate in outline, trilobation distinct. Cephalon sublunate in outline, convex, anterior border rather thick and rounded, posterior margin concave, genal angles rounded. Glabella large, convex, greatest elevation and greatest width near the anterior margin, well defined by the dorsal furrows; anterior lobe large, transversely elliptical, rising abruptly from the anterior border; it comprises more than half of the glabella; anterior pair of lateral furrows originating at the anterior angles of the eyes, passing obliquely backward but not crossing the glabella; second pair of lateral furrows smaller than the first and directed obliquely forward forming a pair of triangular lateral lobes; the third pair of lateral furrows bifurcate, the anterior forks extending forward parallel to the second lateral furrows defining the quadrangular second lateral lobes; the posterior forks extend backward until they join the occipital furrow isolating the small, posterior, glabella lobes; occipital segment elevated 
at its posterior margin, sloping to the occipital furrow; occipital furrow narrow, distinct. Dorsal furrows narrow and deep, nearly parallel from the posterior margin of the cephalon to the third, lateral glabella furrows, thence diverging to the antero-lateral margins. Cheeks slope regularly to the lateral margins; marginal borders wide at the genal angles, narrowing in each direction, marginal furrows shallow on the lateral margins, deeper on the posterior margins; palpebral lobes large, prominent, but not equaling the glabella in height; marked by a distinct furrow just within and parallel to the borders of the eyes; eyes large, lunate, extending from the posterior cheel furrows to the anterior glabella furrows, eye facets arranged in vertical rows of five facets each; the facial sutures originate on the lateral margins in front of the genal angles, curve inward with a sigmoid curve to the posterior angles of the eyes, follow the inner margin of the eyes to their anterior angles and thence pass forward to the anterior margin of the cephalon.

Thorax distinctly trilobed, composed of eleven segments. Axis convex, occupying somewhat more than one-third the width of the thorax; the pleural segments extend outward from the dorsal furrows for a little more than one-third their length, from which point they bend backward and abruptly downward to the lateral margins; extremities rounded; a straight groove originates near the anterior edge of each of the pleural segments at the dorsal furrows, extends slightly backward and outward and becomes obsolete on the flattened surface of each segment. The dorsal furrows converge slightly to the ninth thoracic segment, then more abruptly to the pygidium.

Pygidium subsemicircular in outline, slightly produced posteriorly, strongly trilobed. Axis narrow, convex, margins slightly incurved, abruptly rounded posteriorly; there are ten sinuous annulations; dorsal furrows narrow and deep, entirely surrounding the axis; the pleural lobes, consisting of six to eight segments, each bearing a median groove, curve slightly upward in their anterior portion, then downward to the margins. The segments are defined by grooves which are distinct in the anterior portion of the pygidium but gradually become obsolete posteriorly. This feature is more noticeable in young specimens. Both segmentation and median grooves become obsolete a short distance from the margins, thus leaving a smooth, undefined, marginal border.

The surface of the thorax and pygidium appears smooth to the eye, but under a magnifier it appears finely punctate, without nodes or spines. The surface of the cephalon is pustulose, the 
pustules on the glabella being somewhat more prominent than those on the other parts.

The dimensions of the type specimen (Field Mus. No. P 17024) are as follows: Length $24.2 \mathrm{~mm}$. ; width at genal angles $11.5 \mathrm{~mm}$.; length of cephalon on median line $6.7 \mathrm{~mm}$.; length including genal angles $7.4 \mathrm{~mm}$.; length of thorax $11.5 \mathrm{~mm}$.; length of pygidium $6 \mathrm{~mm}$.; greatest width of pygidium $8.7 \mathrm{~mm}$. A detached pygidium (Field Mus. No. P 16923A) measures, length $11.0 \mathrm{~mm}$; greatest width $14.6 \mathrm{~mm}$.; it has ten annulations in tbe axis and eight segments in each pleural lobe, the last two being visible only with a magnifier. This is the largest pygidium observed and appears to belong to an old individual.

A small coiled specimen in the collection of Mr. A. G. Becker, found associated with typical specimens, is doubtfully referred to this species. It differs from the type in having a smooth instead of a pustulose glabella and the pygidium appears to be shorter in proportion to its width. Considering these characters in connection with its small size, it is probable that they only indicate the immaturity of the specimen. Its dimensions are: Length of cephalon $5 \mathrm{~mm}$.; length of thorax $10.4 \mathrm{~mm}$.; length of pygidium $3.3 \mathrm{~mm}$.; width at genal angles $6.8 \mathrm{~mm}$.; width at anterior margin of pygidium $4.9 \mathrm{~mm}$.

$P$. fredricki is distinguished from $P$. larrabeei by having tive rows of eye facets instead of eight, by its more inflated ariterior portion of the glabella; by its thicker and shorter anterior margin, by its shorter pygidium and fewer annulations on its axis, and by the anterior limbs of the facial suture being less divergent. So far as is known to the writer, the number of rows of eye facets has not previously been used as a specific character, but it seems to be a constant character in the thirty specimens of the two species which he has observed. Specimens of $P$. callicephulus from the Trenton of Ottawa, Canada, which appear to be typical, have eight rows of eye facets. $P$. fredricki appears to be related to $P$. callicephalus, but aside from the eye facets, the glabella is more inflated anteriorly and the anterior margin is smaller and less angular in $P$. fredricki.

The specific name is given in honor of Dr. Fredrick Becker, who was one of the first collectors of fossils in Fayette cointy and who gave the writer much valuable information as to localities.

Localities and horizon.-The type is from the top of the Lower Maquoleta beds at Bloomfield. The species has been observed in beds somewhat lower down at Clermpnt and at Postville June. tion." After Slocom 1916. 
The collecting trip to northeastern Iowa yielded no additional material of this species.

\section{Pterygometopus Larrabeet Slocom}

$$
\text { Plate XX, figs. 8, } 9 \text {. }
$$

1913. Pterygometopus larrabeci Slocom, Field Mus. Nat. Hist., Geol. Ser., vol. 4, p. 81, pl. XVIII, figs. 6-8.

1916. Pterygometopus larrabeei Slocom, Iowa Geol. Survey, vol. XXV, Ann. Rep. 1914, p. 235, pl. XIX, figs. 6-8.

“Type specimen No. P 11256 Field Museum.

Cephalon sublunate in outline, anterior margin produced into a thin subangular lip, genal angles well back of the occipital ring, rounded. Glabella large, depressed, convex, about twice as wide in front as at the occipital ring, anterior lobe transversely elliptical, sloping gently towards the front, comprising fully half the glabella; anterior pair of glabella furrows originating at the anterior angles of the eyes and passing obliquely backward but not meeting at the median line of the glabella; second pair of glabella furrows shorter and shallower than the first, directed obliquely forward; third pair of glabella furrows directed towards the axis of the glabella for a short distance, then bifurcating, the posterior forks bending abruptly backward and joining the occipital furrow leaving the small posterior lobés entirely detached; the anterior and larger forks bending obliquely forward defining the third glabella lobes; occipital segment wide, slightly rounded, of about uniform width until near the dorsal furrows where it is abruptly constricted; occipital furrow shallow but distinet. Dorsal furrows narrow and deep, nearly parallel from the posterior margin of the cephalon to the posterior glabella furrows, thence diverging in a regular curve to the anterior angle of the eyes where they become obsolete. Palpebral lobes large, prominent, exceeding the glabella in height, marked with a distinct furrow just within and parallel to the border of the eye; eyes large, lunate, extending from the posterior cheek furrows to the anterior furrows of the glabella; eye facets arranged in vertical rows of eight facets each; the cheeks curve regularly to the lateral margins, marginal borders rather wide on their lateral margins, narrow on their posterior margins, marginal furrows shallow on their lateral margins, narrower and deeper on the posterior margins. The facial sutures originate on the lateral margins well in front of the genal angles, curve inward and backward to the posterior angles of the eyes, follow the inmer margin of the eyes 
to their anterior angles and thence curve outward to the margin of the cephalon, almost in line with the anterior furrows of the glabella. Surface of the glabella distinctly pustulose; that of the palpebral lobes, cheeks, occipital ring and anterior projection finely granulose.

Thorax not known.

Pygidium subtriangular, somewhat rounded posteriorly, distinctly trilobed. Axis narrow convex, margin slightly incurved, abruptly rounded posteriorly; there are thirteen sinuous annulations; the dorsal furrows entirely surround the axis; the pleural lobes, marked by seven or eight segments each bearing a median groove for part of its length, curve regularly to the lateral margins; both segmentation and grooves become obsolete a short distance from the margin, leaving a plain, undefined marginal border. The entire surface of the pygidium is finely punctate.

Measurements.-Type specimen (Field Mus. No. P 11256). Length of cephalon on median line $9.5 \mathrm{~mm}$., length including genal angles $10 \mathrm{~mm}$., width of cephalon $14.5 \mathrm{~mm}$.; length of pygidium $9.2 \mathrm{~mm}$., width $10.6 \mathrm{~mm}$., width of axis on anterior margin of pygidium $3 \mathrm{~mm}$., length of axis $7 \mathrm{~mm}$. Another complete cephalon gave the following:- Length on median line $11 \mathrm{~mm}$., length including genal angles $12.5 \mathrm{~mm}$., width $17.5 \mathrm{~mm}$.

Remarks. - The above description is based on the type specimen (Field Mus. No. P 11256) consisting of a complete cephalon and a nearly complete pygidium. In general form this species resembles $P$. callicephalus but differs from it in the following characters: In $P$. larrabee $i$ the cephalon is longer in proportion to the width; the cheeks do not curve so abruptly to the lateral margins; the glabella is less inflated anteriorly; the pygidium is longer and has more annulations and segments; the pustulose surface occurs only on the glabella; the surfaces of the palpebral lobes, occipital ring and cheeks are punctate. The pygidium of $P$. larrabee $i$ appears to be midway between $P$. callicephalus and $P$. intermedius in form. The specific name is given in memory of the late Ex-Governor William Larrabee on whose property some of the specimens were collected.

Locality and horizon.-More or less complete cephalons and pygidia are comparatively abundant in the Lower Maquoketa beds at Clermont, Elgin and Bloomfield. The type specimen came from Clermont.' After Slocom 1916.

Moderately well preserved dismembered parts of $P$. larrabee $i$ are commonly found in the localities given by Slocom. Numbers 9201, a cephalon, 9203, a pygidium, and 9254, a lot of five cephala and one pygidium, are all from the Patrick Leehy farm near Cler- 
mont. Number 9255, a cephalon, comes from the Elgin member of the Maquoketa at Dover Mills.

\section{TRILOBITES OF THE SILURIAN Order OPISTHOPARIA}

Family ILLAenidaE

ILlaenus Ioxus Hall

Plate XXII, fig. 1.

1843. Bumastus barriensis Hall (non Murchison), Geol. New York, pt. 4, p. 102, fig. 4, p. 101; tab. org. rem., 10, fig. 4, and 19, fig. 2 .

1867. Illaenus ioxus Hall, 20th Rept. New York State Cab. Nat. Hist., p. 378, pl. 22, figs. 4-11, pl. 23, fig. 1.

1907. Illaenus ioxus Weller. Chicago Acad. Sci., Nat. Hist. Surv., Bull. IV, pt. 2, p. 222, pl. 18, figs. 1-3.

Description - Cranidium large, subquadrate, moderately convex, broadly rounded and subtruncate in front, sides constricted opposite the center. Glabella continuous with the cranidium in front of the eyes, defined posteriorly by broad, shallow dorsal furrows which converge in a gentle curve from the posterior margin of the cephalon to a point opposite the anterior angle of the eyes, whence they become obsolete. Palpebral lobes large, gently rounded but not rising to the height of the glabella, ending about midlength of the cranidium. The facial suture describes a narrow sigmoid curve in front of the eyes, cufting the antero-lateral margin of the cranidium in a straight line in front of the outer margin of the palpebral lobes. The width of the cranidium is slightly greater than the length.

Position and locality.-Specimen 9231, Niagaran, LeClaire beds, in the lower lime quarry at the Palisades, southeast of Bertram, Iowa (Ben H. Wilson).

This species occurs in the dolomitic LeClaire limestone and, though widely distributed in adjoining states and in the east, appears to be very limited in its horizontal and vertical distribution in Iowa. The only locality in this state from which it has been reported is the Palisades, where it is fairly common but in- 
completely preserved. Professor Norton (Iowa Geol. Survey, IV, p. 130) reports that "at the lower lime quarry, now abandoned, there are numerous nests of the saucer-like cephalic and tail shields of Illaenus ioxus." The subtruncate anterior margin, the moderate convexity, the large size, and the shallow short dorsal furrows distinguish it from other species of this genus.

One incomplete cranidium was found by the writer in loose material in a quarry of the Maquoketa formation near Ossian, Iowa. This specimen, No. 9172, was evidently drifted in or let down from an erosion remnant of the Niagaran beds.

\section{ILLAENUS IMPERATOR Hall}

Plate XXI, figs. 1-3.

1861. Illaenus imperator Hall, Rept. Prog. Geol. Surv. Wisconsin for 1860, p. 49 . Niagaran, Racine, Wis.

1870. Illaenus imperator Hall, 20th Rept. New York State Cab. Nat. Hist. (rev. ed.), p. 420, pl. 22, figs. 15-17; pl. 23, figs. 2-3. Niagaran, Wis.

1907. Illaenus imperator Weller, Chicago Acad. Sci.; Nat. Hist. Surv. Bull. IV, pt. 2, p. 225, pl. 16, figs. 13-16. Niagaran, Joliet, Ill.

Description.-Cranidium subquadrate, strongly convex, wider than long, anterior margin broadly rounded, posterior margin curved backward across the glabella. Dorsal furrows short but deep, straight and converging slightly from the posterior margin forward. Glabella broad, occupying one-half the width of the cranidium, and confluent with the general surface near the midlength of the shield. Palpebral lobes small, situated close to the posterior margin of the head, rising at first abruptly from the dorsal furrows thence continuing laterally in a nearly horizontal plane. Eyes narrow, lunate, resting on a well-defined orbital ridge (see specimen 9218). Free cheek narrowly depressed and sulcate about the base of the orbital ridge, thence sloping abruptly to the margin.

The length of a small cranidium, No. 9221 , is $28.5 \mathrm{~mm}$., and the width $35.5 \mathrm{~mm}$. across the palpebral lobes.

Position and locality.-Niagaran, Hopkinton dolomite, southeast of Monticello ; Niagaran, Farley, Hopkinton, and Maquoketa. 
Remarks.-Most of the specimens which have formerly been referred to $I$. imperator in Iowa are now referred to $I$. slocomi. The latter species has some points of resemblance as already pointed out in the remarks under that species. The University museum has four cranidia and one incomplete free cheek which undoubtedly belong to this species. All are of small size. To date no pygidium of $I$. imperator has been found in this state.

\section{ILLAENus slocomi n. $\mathrm{s}$.}

Plate.XXI, figs. 4-6.

Description.-Cranidium subhenispherical in shape, strongly and evenly convex, sides diverging slightly in front of the palpebral lobes, thence curving uniformly with the anterior margin. Posterior margin nearly straight. The length is nearly equal to the width. Glabella broadly convex, occupying nearly one-half of the width of the cranidium, sides curved gently inward. Dorsal furrows well defined and bearing a distinct elliptical impression near their anterior extremity. Eye lobes small and short, situated close to the posterior margin of the cranidium. Posterior limbs of the fixed cheeks short and deflected abruptly downward. The anterior margin of the cranidium bears a few indistinct and widely separated lamellose lines.

Pygidium transversely subelliptical; inner and anterior half depressed convex, the outer portion sloping in a broad curve to the margin. Trilobation distinct anteriorly. Antero-lateral angles obliquely truncate. Axis low and depressed, curving gently forward on the anterior margin, sides subparallel, ill-defined posteriorly and confluent with the general convexity of the surface. The greatest width of the pygidium is considerably less than twice the length.

Dimensions.-The type cranidium, No. 9215 , is $62 \mathrm{~mm}$. long and $63 \mathrm{~mm}$. wide. Pygidium No. 9220 is $48 \mathrm{~mm}$. long and $82 \mathrm{~mm}$. wide.

Position and locality.-Niagaran, Maquoketa and Hopkinton (Dr. Samuel Calvin).

Remarks.-In many respects this species compares favorably with Illaenus imperator and has commonly been so identified in the various county reports. However, a careful examination re- 
veals a number of differences which are practically constant for seven cranidia and three pygidia at hand. The position of the eyes, the size of the glabella and the general convexity of the pygidium agree closely with $I$. imperator but the cranidium is much more convex, considerably longer in proportion to its width, the anterior margin is more evenly rounded and the palpebral lobes are less prominent; the pygidium differs also in being proportionately longer.

There is a good deal of difference in size. The cranidia range in length from 49 to $84 \mathrm{~mm}$. and the pygidia from 48 to $74 \mathrm{~mm}$.

The species is named in honor of Mr. Arthur W. Slocom, who first recognized (in communication with Doctor Thomas) some of the differences between this species and I. imperator.

\section{ILLAENUS TRIANGULARIS $n$. $s$.}

Plate XXII, figs. 2-4.

Description.-Pygidium subtriangular in outline, surface depressed convex over the median area, sloping in a broad curve to the sides and in an increasingly stronger and shorter curve toward the posterior margin, which is parabolic in outline with the antero-lateral angles. Anterior margin nearly straight, axis curved gently forward, antero-lateral angles obtusely rounded. Length is to width as three is to four. Axis depressed, scarcely rising above the pleural lobes, well defined along the anterior margin, thence very obscurely until it becomes confluent with the general surface along the posterior third of the pygidium. The width is one-third the width of the shield. The type specimen, No. 9226, is $59 \mathrm{~mm}$. long and $80 \mathrm{~mm}$. wide.

Position and locality.-Niagaran, Hopkinton. Collected by Professor Calvin.

This species is readily distinguished from other species of Illaemus by the depressed dorsal surface, the depressed axis and the distinct triangular outline. No cephalon has been found that might be referred to this species. 


\section{ILlameus Lobatus n. s.}

$$
\text { Plate XXI, figs. 7, } 8 .
$$

Description.-Pygidium subsemiovate in outline, anterior margin straight between the axis and the geniculation, curved across the axis, obliquely truncate at the antero-lateral angles. Length is to width as three is to four. Dorsal surface depressed convex, the sides and posterior fifth curving abruptly downwärd and under at the margin. This marginal incurvature is greatest posteriorly, decreasing gradually toward the antero-lateral angles. Axis occupying about one-third the entire width along the anterior margin, gently rounded, and rising slightly above the pleural lobes, becoming confluent with the general surface of the pygidium at its midlength. Dorsal furrows broad, very short and shallow. The outer margin is marked by several strong lapellose lines.

Length of specimen $9230,37 \mathrm{~mm}$., width $50 \mathrm{~mm}$.

Position and,locality.-Niagaran, two and one-half miles west of Manchester. Collected by Professor Thomas.

Remarks.-In general outline and the character of the dorsal surface this species agrees more closely with the original description of the pygidium of $I$. daytoni Hall and Whitfield than with any other Silurian species of this genus. Foerste ${ }^{15}$ subsequently figured a profile view of a pygidium of $I$. daytoni which was taken from the type locality. This shows the posterior marginal curvature, parallel to the median longitudinal axis, to be quite different from that of our specimen. In the former the posterior margin has a backward slope whereas in the latter there is a distinct forward curvature ventrally. This difference is so striking that, in spite of the similarity of descriptions, I. lobatus can not be identified with 1 . daytoni.

Only the type specimen is known at the present time.

Family GOLDIIDAE.

$$
\begin{gathered}
\text { Goldius LaPHaMI (Whitfield) } \\
\text { Plate XXII, figs. 5, 6, } 7 .
\end{gathered}
$$

1878. Bronteus laphami Whitfield, Ann. Rep. Wisconsin Geol. Surv. for 1877, p: 88. Niagaran, Kewaunee, Wisconsin. 
1882. Bronteus laphami Whitfield, Geol. Wisconsin, vol. IV, p. 310 , pl. 22, figs. 1-4. Niagaran, Kewaunee, Wisconsin.

1915. Goldius laphami Bassler, Bibliographic Index of American Ordovician and Silurian Fassils, vol. I, p. 559.

Description._"Glabella short and broad, very depressed convex, the division of parts somewhat obscure. Anterior lobe very broad in front, and rapidly decreasing in width from its junction with the marginal rim to behind the middle of its length, where it is not more than two-thirds as wide as in front; dorsal furrow obscure; posterior glabellar furrow well marked; occipital furrow distinct and the occipital ring rather large. Fixed cheeks narrow and rounded, indistinctly separated from the anterior lobe of the glabella in the middle, but not definitely so at the sides, its surface rather strongly striated." (Whitf. op. cit., 1882.)

Pygidium paraboloid in outline, nearly straight in front, broadly rounded behind, sides converging slightly, antero-lateral angles rounded, margin smooth. The axis is very short, moderately convex, well defined by deep dorsal furrows, elevated above the pleural lobes and marked by a submarginal annulation at the anterior end. Its length is about one-fourth the length of the pygidium. Pleural lobes broad, gently convex, sloping at first gently away from the axis thence more abruptly to the slightly recurved marginal zone. Each lobe bears seven well-defined segments which are broad, gently rounded to flattened, increasingly elongate and oblique from front to back and end at the margin. Extending back from the axis there is a long central segment which is narrower away from the axis for one-third of its length, whence it gradually increases in width to the margin, bifurcating approximately at its midlength, but in some specimens much nearer the axis, causing the posterior half of the segment to be double. The intersegmental grooves are deep, comparatively narrow, and well defined from the dorsal furrow outwards, obsolete at the margin.

The surface markings seem to depend more or less directly on the nature of the preservation. In one specimen (No. 9049) which preserves a part of the dorsal crust the segments are covered by numerous fine tubercles, but where the crust has been removed there are numerous subparallel, reëntrantly curved grooves and ridges concentrically arranged between the intersegmental 
grooves. In other specimens all the segments bear squamose transverse marks, also concentrically arranged, but obsolete in the intersegmental grooves. Still other specimens are entirely smooth.

The size of the pygidia varies considerably. Our smallest specimen has a length of $23 \mathrm{~mm}$. and the largest specimen, if complete, would measure $100 \mathrm{~mm}$.

Position and localities.-Numbers 9049, 9050, 9051 are from the Niagaran dolomite at Clinton. Collected by Dr. Farnsworth.

Number 9052 is from the Niagaran non-dolomitic beds of Hopkinton, south half of section 20, Coffins Grove township, Delaware county. . Collected by Professor Thomas.

Number 9053 is from the Hopkinton dolomite of the Niagaran, Scotch Grove. Collected by Professor Thomas. Number 9048, from the Niagaran, Coralline beds, one-fourth mile east of Central City, was collected by Doctor Calvin. Number 9054, from the Niagaran dolomite at Maquoketa, was collected by Doctor Calvin. Number 9055, from the Niagaran dolomite at Monmouth, was collected by L. W. Stuart.

Remarks.-Entire specimens of G. laphami are unknown at the present time, nor have complete heads been recorded from any localities either within the state or elsewhere. The description of the glabella by Whitfield is included above for the sake of completeness but the writer seriously doubts that either this description or figure 1, Plate 22 of Whitfield, representing this description, is of a true glabella. Judging from the figure alone this specimen appears to be a hypostoma very likely belonging to this species since it is found associated with the pygidia. Our description of the pygidium is based on seven more or less fragmentary pygidia all of which have been collected in Iowa, which is thus far only the second state from which this beautiful species has been recorded.

\section{Family LICHADIDAE}

Arctinurus (Metopolichas) obvius (Hall)

Plate XXIII, fig. 3.

1870. Lichas obvius Hall, 20th Rep. New York State Cab. Nat. Hist. rev. ed., p. 424, pl. 25, fig. 19. Niagaran, Lyons, Iowa. 
1885. Lichas (Oncholichas) obvia Schmidt, Mem. l'Acad. Imp. St. Petersburg, 7th. ser., 33, p. 31. Niagaran, Lyons, Iowa.

1893. Lichas obvius Vogdes, Bibliography Paleozoic Crustacea, p. 320 . Niagaran, Lyons, Iowa.

1907. Arctinurus obvins Weller, Chicago Acad. Sci. Bull. IV, pt. II, p. 186. Niagaran, Lyons, Iowa.

1915. Arctinurus obvius Bassler, Bibliographic Index of North Am. Ordovician and Silurian Fossils, p. 66.

Description.- The following is a copy of the original description by Hall.

"Glabella gibbous, broad in front, length equal to the width between the eyes; occipital and dorsal furrows sharply defined; lateral lobes simple, of nearly equal width throughout, suddenly contracting near the base; surface finely pustulose."

Formation and locality.--In the limestone of the Niagara group, at Lyons, Iowa. From Dr. Farnsworth.

Remarks.-The type specimen upon which this species was erected is now in the possession of the American Museum of Natural History at New York City. The museum number of this specimen is 2154 . No additional specimens of this species have been encountered.

This species is here referred to the genus Arctinurus with Metopolichas as a subgenus, - see remarks under the next species. In the absence of pygidia the true generic reference is somewhat problematical and it is possible that this species may again be referred to the genus Lichas if pygidia should be found which have a notched rather than a broadly rounded posterior margin.

\section{Metopolichas iowensis n. $\mathrm{s}$. \\ Plate XXIII, figs. 1, 2.}

Description.-Glabella markedly convex, broadly rounded in front, obscurely rounded behind, sides sloping moderately, front sloping abruptly to the margin, which is bordered by a thickened, narrow and closely appressed rim adjacent to a shallow and narrow groove. The median lobe is subclavate in outline, widening abruptly toward the anterior end and forming on either side at the greatest width a winglike lateral subangular extension which ends marginally in front of the lateral lobe. The greatest con- 
striction is two-fifths the length of the median lobe from the occipital groove. Posterior to this constriction there is a short but abrupt expansion followed by subparallel sides to the base. The width at the base is slightly less than one-half the greatest width across the anterior margin. The large side lobes are tricomposite, being formed by the coalescence of the first, second and third lateral lobes. They are separated from the median lobe by a narrow but sharp and well defined groove; in shape they are subreniform, being broadly curved along the inner margin, more sharply curved along the outer margin and of nearly uniform width throughout except for a constriction of the posterior portion. Antero-laterally the lobes are sharply rounded to wedgeshaped, ending submarginally between the lateral extension of the median lobe and the anterior end of the fixed cheeks; posteriorly they are restricted and truncated and end at the occipital furrow. A faint lateral furrow extends diagonally forward across each of the side lobes, indistinctly subdividing them near their midlength.

The occipital lobes are small, subtriangular and located direct- ly back of the large side lobes. The anterior margin of each occipital lobe is transverse in direct line with the occipital groove; the posterior margin is curved and encroaches upon the occipital segment, from which it is delimited by a narrow sharp groove. The occipital segment is broad, gently arched, of uniform width back of the median glabellar lobe but constricted in the region of the occipital lobes.

The fixed cheek is small, posterior in position, depressed convex, narrow and continued toward the posterior end of the occipital segment.

The entire surface of the cephalon is covered by tubercles of varying sizes. A few of the coarser ones are scattered irregularly over the median glabellar lobe, being especially prominent over the median inflated portion.

Free cheeks, thorax, and pygidium unknown.

Position and locality.-The holotype, No. 9043, was collected by Mr. Fred. Orelup from the Niagaran dolomite at Clarence, Cedar county. 
Remarks.-Dr. Aug. F. Foerste ${ }^{16}$ suggests that the holotype "is generically a Metopolichas acording to American usage of. that term." That it does not belong to the genus Arctimurus is evident from the fact that Arctinurus has no occipital lobes, whereas our specimen has very distinct occipital lobes.

$M$. iowensis bears a close resemblance to Arctinurus (Metopolichas) obvius (Hall) but is distinguished from the latter primarily in the configuration of the posterior portion of the median glabellar lobe. In $M$. obvius the sides diverge, forming an acute angle with the occipital groove; in $M$. iovensis the sides are subparallel, meeting the occipital groove almost at a right angle. This makes the width along the occipital groove proportionally narrower for $M$. iowensis than for $M$. obvius. The surface of the former is covered by numerous tubercles while the surface of the latter is covered with small pustules.

\section{Arctinurus anamosa n. s.}

Plate XXIII, Figs. 4-9.

Description.-Cephalon subsemicircular in outline, convex • transversely and longitudinally, length approximately equal to three-fifths the greatest width across the eye lines. Glabella subquadrate to subpentagonal in outline, wider in front than behind, bounded laterally by deep, wide dorsal furrows and anteriorly by a well-defined groove within a narrow thickened margin. Median lobe capstan-shaped with a narrow base, widest in front where it occupies nearly four-fifths of the width of the glabella and anterolateral winglike extensions which end in front of the lateral lobes ; the sides converge abruptly at first thence more gently along a curved line within a short distance of the base where there is an abrupt expansion to the occipital furrow; the width of the narrowest part, just in front of the posterior expansion, is one-fifth the greatest width; anterior margin broadly rounded, posterior margin straight. Lateral lobes compound, large, convex, ovalelongate, extending from the antero-lateral part of the glabella to the occipital furrow; sides of lobes subparallel; anterior end narrowly rounded; the outer margin sigmoid, postero-lateral

10 Personal communication, May 2, 1921. 
angle truncated at occipital border. Each lobe bears at its midlength along the inner margin a slight constriction which represents the last faint trace of the second glabellar furrow. The fixed cheek is narrow in front of the eye, widening abruptly between the palpebral lobe and the dorsal furrow and is then produced laterally back of the eye almost to the outer margin. Along the posterior margin it bears the lateral continuation of the occipital groove. The facial suture is faintly discernible on the right side of specimen No. 9044. From the postero-lateral angle of the cephalon it is directed obliquely forward, thence inward along a curved line to the posterior margin of the eye, in front of which it is continued along a gentle convex curve to the anterior margin, cutting the latter at an acute angle. The eyes are lost from the specimens at hand but the size and shape of the eye-base and the reniform palpebral lobe are preserved. There is an impressed groove beneath the eye on the free cheek. The free cheek is small, triangular, rising abruptly from the outer margin to the base of the eye, where it is depressed, bearing a definite suboceular ridge limited to the free cheeks. The free cheek terminates at each extremity in a. short sharp spine. The posterior spine rests against the distal border of the posterior limb of the fixed cheek. Occipital segment broad, of nearly uniform width and arched transversely. Occipital furrow broad, deep and welldefined throughout and continuous laterally with the posterior furrows of the fixed cheek.

Surface covered with numerous irregularly scattered, coarse and fine tubercles.

Thorax and pygidium unknown.

Dimensions.-No. 9044.

Length along median line

Width across eye line

Greatest width of median glabellar lobe

Greatest width of same at occipital furrow $7 . \mathrm{mm}$.

Position and localities. -Numbers 9044 and 9045, two cranidia

from the Niagaran dolomite in the vicinity of Anamosa. Collected by A. E. Wyant. The foregoing description of this species is based on two heads,
$21.5 \mathrm{~mm}$.

34. $\mathrm{mm}$.

$16.5 \mathrm{~mm}$. 
both of which came from the same locality. One of these, No. 9044 , is nearly complete; the fixed cheek and eye is missing from the right side but on the left side only the eye is missing. The surface of this specimen has been considerably worn so that only a few tubercles remain on the antero-lateral region of the median glabellar lobe. In specimen No. 9045 both the eyes and fixed cheeks are missing.

In general form this species resenubles Arctinums chicagoensis Weller, from the Silurian of Hawthorne, Illinois, but differs from the latter in the configuration of the median glabellar lobe.

In A. anamosa the greatest constriction of the median glabellar lobe is proportionally farther back than in $A$. chicagoensis and the occipital lobe is well defined throughout in the former, while in the latter it is ill-defined and shallow back of the median glabellar lobe. Arctinurus chicagoensis is said to have a shallow and ill-defined occipital furrow back of the median glabellar lobe while in $A$. anamosa it is strong and well defined.

\section{Order PROPARIA Beecher \\ Family encrinuridae Angelin \\ Encrinurus ornatus Hall and Whitfield \\ Plate XXIII, figs. 11-15.}

1852. Cybele punctata Hall, Pal. New York, vol. 2, p. 297, pl. $66 \mathrm{~A}$, figs. 1a-1.

1866. Encrinurus punctatus Billings, Cat. Sil. Foss. Anticosti, Geol. Surv. Canada, p. 61.

1875. Encrinurus ornatus Hall and Whitfield, Pal. Ohio, vol. 2. p. 154, pl. 6, fig. 16.

1896. Encrinurus cf. E. punctatus and ornatus Norton, Proc. Iowa Acad. Sci., vol. 3, p. 79.

1907. Encrinurus ornatus Vogdes, Trans. San Diego Soc. Nat. Hist., vol. 1, no. 2, p. 67.

Description.-General form ovate-elongate, broadly rounded in front, narrowly rounded behind, sides tapering gently from the genal angles to the anterior margin of the pygidium, thence more abruptly to the end. Surface convex and distinctly trilobate throughout. Length is to width as 12 to. 5 . 
Cephalon sublunate to subtriangular in outline, produced into spines at the genal angles; posterior margin straight across the center, curved backward at the sides. Glabella prominent, convex, clavate, extending to the anterior margin, bounded by very deep dorsal furrows. Two pairs of short lateral furrows are present; the first pair is located opposite the eyes, the second pair nearly midway between the first pair and the occipital groove. Occipital segment prominent, smooth and strongly arched, bearing an indistinct node on each side. Occipital groove broad and deep medially, directed obliquely backward across the dorsal furrows and out over the fixed cheeks toward the genal angles. Fixed cheeks triangular in outline, strongly convex and tumid proximally, produced into spines at the genal angles. The facial sutures originate on the lateral margin of the cephalon a short distance in front of the genal angles and are directed obliquely to the eyes, in front of which they pass down the short anterior slope of the cheelss toward the margin. The eyes are pedunculate, rising obliquely outward and forward well above the height of the glabella.

Thorax subrectangular, sides gently rounded and converging toward the pygidium, composed of eleven segments. Length is to width as 3 to 5 . Axis convex and sharply defined by narrow, deep dorsal furrows; sides nearly straight. The segments curve gently forward across the axial line and are slightly constricted at the sides so as to give rise to a small node adjacent to the dorsal furrow. The pleural lobes are flattened for about onehalf their width, thence curve abruptly downward to the margin. The segments are narrow and rounded and of about the same width as the intersegmental grooves.

Pygidium subtriangular in outline, convex, wider than long, antero-lateral angle oblique, sides converging abruptly to an obtusely rounded, and in some specimens gently produced posterior extremity. A distinct caudal spine not observed. Axis well defined by the dorsal furrows, depressed convex, tapering uniformly to an acute termination just within the posterior margin; it is marked by sixteen to twenty-nine segments, of which only the anterior two to five cross the median region. Professor Nor- 
ton (op. cit.) has observed as many as thirty-one segments. The number depends largely upon the size and state of preservation of the specimens. Some specimens are worn so that no segments are visible between the last two median axial nodes. The average number occurring on twenty casts and two impressions was found to be twenty segments. From five to eight median nodes are present on the otherwise smooth area; these are separated at intervals of one to five segments. The pleural lobes rise abruptly from the margin, approaching the axis on a gentle slope. Each lobe is marked by nine or ten ribs which are smaller and increasingly oblique from front to back, the last two being nearly in line with the axis and faintly defined in many specimens.

Surface markings.-All parts of the cephalon, except the grooves and posterior margin, bear well defined tubercles. The glabella bears a distinct row of eight tubercles around the anterior margin. The seventh and tenth segments of the axis of the thorax each bears a strong median tubercle. The pygidium bears, in addition to the axial tubercles previously mentioned, a tubercle on each pleural segment near the axis and a smaller one farther out. This character is shown only in unusually well preserved specimens.

Dimensions.-Specimen 9210, total length of body $38 \mathrm{~mm}$, width at the genal angles $20 \mathrm{~mm}$, length of thorax $15 \mathrm{~mm}$, length of pygidium $12 \mathrm{~mm}$., width of same $15 \mathrm{~mm}$.

Position and locality.-Near the top of the Anamosa beds of the Niagaran, Platner and Kirby's quarry, Mount Vernon (Prof. William H. Norton and Prof. A. Collins).

Remarks.-This species was first mentioned in this state by Professor Norton. (op. cit.) who made a careful and accurate analysis of the position of the nodes on the pygidial axes of fortythree specimens, and arrived at the significant conclusion that the position of these nodes on the axial segments can not be made the basis for specific rank. The analysis shows that the nodes do occur on any one of the segments up to twenty-three. These data are especially valuable and enlightening because'all the specimens were talken from a single locality of very limited horizontal and vertical range. Vogdes (op. cit. p. 69) likewise discredits 
the value of the distribution of the nodes for specific distinction.

The preceding description is based on an internal mold of a complete specimen, one complete cast and twenty pygidia. The cast and pygidia were kindly loaned to the writer for study. They represent a part of the original forty-three specimens used by Norton as indicated above. All conform to the type of E. ornatus rather than to the European E. punctatus, which is characterized by a long caudal spine and a tuberculate posterior margin of the cephalon. This fine lot is in the Norton collection, Cornell College.

\section{Family CALYMENIDAE \\ CaLymene niagarensis Hall \\ Plate XXIV, figs. 1-5.}

1843. Calymene niagarensis Hall, Geol. New York, pt. 4, p. 102, fig. 3, p. 101, tab. org. rem. 10, fig. 3. Niagaran, Lockport and Rochester, New York.

1865. Calymene niagarensis Hall, Adv. Sheets, 18th Rep., New York State Cab. Nat. Hist., p. 30. Niagaran, Wisconsin.

1867. Calymene niagarensis Hall, 20th Rep. New York State Cab. Nat. Hist., p. 30. Niagaran, Racine, Wisconsin.

1879. Calymene niagarensis Hall, 28th Rep. New York State Mus. Nat. Hist. (mus. ed.), p. 187, pl. 32, figs. 8-15. Niagaran, Waldron, Indiana.

1907. Calymene niagarensis Weller, Trilobites of the Chicago Area, p. 261, pl. XXIII, figs. 9-1.0. Niagaran, Bridgeport, Hawthorne, Joliet, near Lemont, etc., etc., Ill.

Note-For a more complete bibliography see Vogdes, "Bibliography of Paleozoic Crustacea," 1893, Weller, op. cit. 1907, or Bassler, "Bibliographic Index of American Ordovician and Silurian Fossils," 1915.

Description.-Body suboval-elongate in outline, anterior and posterior ends bent strongly downward, thorax "sway-backed", sides nearly straight and tapering uniformly from the occipital segment to the anterior border of the pygidium, thence more abruptly to the posterior end. Trilobation distinct throughout, the axis tapering gradually and uniformly from front to back.

Cephalon subsemicircular in outline, about twice as wide as long, anterior margin describing a broad curve with the free cheeks, posterior nearly straight or curving slightly forward. 
Glabella very prominent, rising distinctly above the surface of the cheeks, rounded transversely, arched longitudinally and bordered anteriorly by a broad shallow concave groove within the recurved margin. Sides straight, diverging from front to back. Frontal lobe subquadrate, truncated in front and occupying a little less than one-third of the glabella. Lateral lobes three, increasing in size from front to back. On the posterolateral angles of the frontal lobe of well preserved adult specimens there is a faint ridge which simulates a very small lateral lobe. Situated immediately back of this ridge is the first pair of small nodelike lateral lobes. The second pair of lateral lobes is considerably larger, appressed against the sides of the glabella and sharply defined by the short second lateral furrows in front and the much larger third lateral furrows behind. The third lateral furrow bifurcates indistinctly on the dorso-lateral side of the glabella, the shorter branch extending forward to the upper posterior border of the second lateral lobe and the larger branch curving back toward the occipital segment. The third lateral lobes are very large, oval in shape and almost pinched off from the glabella. Each of these lobes occupies nearly one-third the posterior width of the glabella. The occipital segment is strongly arched and forms the highest part of the body. The occipital groove is shallow and curved forward above, but is very deep back of the third lateral lobes. Near the anterior end of each dorsal furrow there is a conspicuous antennal pit. The fixed cheek is large, narrow in front of the eye, broad back of the eye and extended to the genal angle where it ends in a point. The eyes are small, nodelike, surrounded by a broad shallow groove and sitnated on the proximal angle of the free cheeks opposite the second glabellar furrows or about midlength of the head. The free cheeks are triangular, highly convex, outer margin evenly rounded, slightly recurved and bearing a wide shallow concave submarginal groove.

The thorax is composed of thirteen segments, highly convex transversely, sides nearly straight, tapering gradually toward the pygidium. Axis prominent, elevated above the pleural lobes and separated from them by well defined dorsal furrows; width a 
little greater than one-third the total width of thorax. Segments strongly rounded and arching slightly forward, separated by broad'shallow grooves above, which are deeper and narrower at the sides. Each segment bears a large node on either side adjacent to the dorsal furrow. Pleural lobes gently rounded near the axis thence sloping almost vertically to the margin. The height from the free outer margin to the shoulder is nearly two times as great as the distance from the shoulder to the dorsal furrow. Each segment bears proximally a broad shallow median groove which is narrower on the lateral slope where it culves near the front margin and ends somewhat below the midlength of the side. Distally the segments are flattened and rounded.

The pygidium is small, transversely suboval in outline, the. posterior margin forming an obtuse angle. Trilobation distinct. Axis prominent, evenly rounded, strongly elevated above the pleural lobes, tapering to a rounded termination well within the margin; segments six to seven, extending to the dorsal furrows and separated by broad grooves. The pleural lobes slope abruptly from the dorsal furrows to the margin. Each lobe is bounded distally by a broad smooth marginal zone which is narrower toward the end of the axis. Segments three to four, well rounded, smooth and extending from the dorsal furrow to the smooth zone. Intersegmental grooves well defined anteriorly, indistinct posteriorly. Pygidium directed downward at nearly a right angle to the axis of the body.

Dimensions.-Number 9057 , greatest length of the body not including the dorsal curvature $61 \mathrm{~mm}$.; greatest width across genal angles $44 \mathrm{~mm}$.; median length of head $18.5 \mathrm{~mm}$.; length of thorax $47 \mathrm{~mm}$. This is an unusually large specimen, with pygidium missing. If complete it probably would have a length of $68 \mathrm{~mm}$. The average length of twenty ordinary size specimens is $35 \mathrm{~mm}$.

Position and localities.-Number 9057, Niagaran, near Farley. Collected by W J McGee. Number 9058, Niagaran, Anamosa. Collected by Samuel Calvin. The species is reported also from the McGlade quarry in South Fork township, Delaware county, as well as from other localities.

Remarks.-In the foregoing description the material from 
Niagaran limestone of Grafton, Illinois, has been freely used. The Iowa material is somewhat limited and much of it is fragmentary but there is no doubt as to its identity with the Mlinois material. All the specimens of this species are unusual in that they are all "sway-backed" when seen in lateral profile and the pygidium, instead of being extended posteriorly is usually directed downward and appressed against the pleural lobes of the thorax. All the Iowa specimens are preserved in either dolomite or chert.

\section{Family CHEIRURIDAE \\ Cheirurus niagarensis (Hall) \\ Plate XXIV, fig. 6.}

1852. Ceraurus insignis Hall, Pal. New York, vol. 2, p. 300, 306, pl. A 66, fig. 4; pl. 67, figs. 9, 10:

1867. Ceraurus niagarensis Hall, 20th Rept. New York State Cab. Nat. Hist., p. 376, pl. 21, figs. 10, 11.

1907. Ceraurus niagarensis Weller, Bull. Chicago Acad. Sci., Nat. Hist. Surv., vol. 4, pt. 2, p. 263, pl. 24, figs. 20, 21.

1913. Cheirurus niagarensis Raymond and Barton, Bull. Mus. Comp. Zool., vol. 54, p. 542 (gen. ref.).

This species appears to be quite rare in Iowa as it is represented by only one incomplete cranidium, specimen 9212 . The glabella is smooth, moderately convex, gently arched longitudinally, subrectangular in outline with sides diverging slightly toward the front, anterior margin rounded, bounded laterally by welldefined dorsal furrows. There are three pairs of strong glabellar furrows: the first pair is directed inward and gently backward, extending approximately half way to the center of the glabella; the second pair is shorter and runs subparallel to the first: the third pair is stronger and continuous with the occipital groove across the axial region, thus delimiting a pair of prominent isolated triangular basal lobes with the occipital groove. The occipital groove is of the same size as the glabellar furrows. The occipital ring is arched slightly above the surface of the glabella, broad medially and narrow at the sides. A part of the right fixed cheek is preserved, showing a pitted surface.' Total length 21 
$\mathrm{mm}$., width across the occipital ring $10 \mathrm{~mm}$. The specimen is preserved in vesicular dolomite.

Position and locality.-Niagaran, Anamosa substage?-Clarence, Cedar county (Fred Orelup).

\section{Family PHACOPIDAE}

\section{Dalmanites platycaudatus Weller}

\section{Plate XXIII, fig. 10.}

1907. Dalmanites platycaudatus Weller, Bull. Chi. Acad. Sci., Nat. Hist. Surv., 4, pt. 2, p. 272, pl. 25, figs. 3-5.

Description.-Cephalon, not including genal spines, subsemicircular in outline, surface moderately convex, anterior margin produced medially into a short, flattened, tongue-like extension; posterior margin within the genal angles nearly straight. Length is to width as 1 to 2. Glabella depressed convex, broadly rounded and widest in front, transverse behind, sides nearly straight and well defined by shallow dorsal furrows converging uniformly to the occipital groove. Anterior lobe large, gently and evenly convex, suboval in outline transversely, its median length equal to one-half the total length of the glabella. The first pair of lateral lobes is wedge-shaped, located opposite the inner anterior margin of the eyes and extending about three-eighths the distance across the glabella; the second pair is subquadrate and equal in width to the inner extremity of the first pair, located opposite the palpebral lobes; the third pair is similar to the second but narrower, and shorter on the posterior margin. The first pair of lateral furrows is large, extending obliquely outward and forward, increasing in width from a pitlike depression near the inner end; the second pair is much shorter, inclined gently forward and inward, and shallow near the dorsal furrows; the third pair appears somewhat longer because it extends undiminished in size to the dorsal furrows. None of the furrows crosses the axial region. The occipital groove is similar on the sides to the last pair of lateral furrows, but opens directly into the dorsal furrows and is very shallow medially. The occipital ring is broad, arched transversely, the center rising above the surface of the lateral 
lobes. Palpebral lobes well defined, rising at first gently, thence more abruptly to the facial sutures around the inner concave margin of the eyes. Eyes large, constricted around the base, rising considerably above the surface of the cephalon, outer surface sloping in front, nearly vertical in back, situated about threeeighths their leingth in front of the posterior margin of the cephalon. Cheeks large, depressed about the eyes, thence sloping uniformly to the margin. 'The posterior cheek furrow is wider and shallower outward. Length of cephalon (No. 9059) along median line $28.5 \mathrm{~mm}$, estinuated width across genal angles $56 \mathrm{~mm}$.

Position and localities.-Niagaran dolomite, Anamosa (Mr. Green); two miles north of Mechanicsville (Professor Norton).

Only two incomplete cephalons represent this species in Towa at the present time. These agree, however, so well with Weller's description that there can be little doubt about their specific identity even though the genal spines have not been preserved. The only difference observed is the absence of a broad flattened marginal border. Specimen 9059 has a slightly flattened border but specimen 9213 has a-distinct sloping border except at the anterior end. This difference may be the result of preservation rather than a specific character.

\section{TRILOBITES OF THE DEVONIAN \\ Order OPISTHOPARIA}

Family GOLDIDAE

Goldius thomasi n. $\mathrm{s}$.

Plate XXV, figs. 2-4.

Description.-Cranidium subquadrate in outline; width across anterior end equal to length including the occipital spine. Anterior margin broadly rounded and bearing a narrow deep marginal sulcus in front of the glabella. This sulcus is deeper and wider laterally. Between the occipital furrow and the third lateral glabellar furrows the dorsal furrows are very deep and subparallel; in the region of the second glabellar lobes they rise abruptly, diverge, and continue as shallow grooves to the marginal sulcus. 
The glabella is prominent, clavate in outline, strongly convex in all directions, rising considerably above the cheeks; the greatest height is in the region of the first lateral furrows; the width across the anterior end is nearly three times that of the posterior end. The frontal lobe is large and quadrangular. The first pair of glabellar furrows are clearly defined as short, straight and smooth depressions. The second lateral furrows are but faint depressions on the surface and do not open into the dorsal furrows. The third or basal furrows appear as constrictions on the sides of the glabella. The occipital furrow is broad and very shallow. The occipital segment is trigonal in outline, gently arched, decreasing in size laterally; the posterior margin is continued into a well defined short flattened spine. The fixed cheeks are large, broadly convex opposite the second and third glabellar lobes, thence sloping gently outward and forward to the broad marginal sulcus in front. The lateral and dorsal furrows are smooth but the remaining surface is covered with numerous pustules of varying size.

Eyes, free cheeks and thorax unknown.

Pygidium small, subsemicircular to parabolic in outline; outer margin entire and spineless, broadly concave and slightly reflexed at the edge; anterior margin nearly straight. The width is to the length as 3 to 2 . The surface is gently convex near the axis and depressed distally. . The axis is short, triangular, raised above the pleuræ, about one-fourth the length of the pygidium and twice as wide as it is long. The fulcral fold across the anterior end is not preserved. No annulations present.

There are fifteen gently rounded to flattened pleural segments radiating from the axis, increasing in width distally and becoming obsolete at the margin. The second and third segments are sharply pointed proximally. The fourth to the seventh segments are curved gently forward near the axis. The proximal fifth of the postaxial or median segment decreases in width distally, thence the segment gradually widens until it becomes obsolete near the margin. The intersegmental grooves are shallow but well defined. The surface, except along the margin and within the 
grooves, is covered with pustules of varying size which are similar to those found on the cranidium.

Dimensions.-Specimen 9085, length of cephalon including the occipital spine $5.5 \mathrm{~mm}$., width across the anterior end $5.5 \mathrm{~mm}$. Specimen 9087, length of pygidium $8 \mathrm{~mm}$., width of same $12 \mathrm{~mm}$.

Horizon and locality.-Owen beds; northwest quarter of the southwest quarter of section 31, Portland township, Cerro Gordo county. Collected by Professor Thomas.

Remarks.-The foregoing description is based on a single cranidium and one pygidium. Both specimens were found in the Owen beds, a few feet above the contact with the fossiliferous marly zone, in a thin bed of hard, crystalline, dark gray, compact limestone which is crowded with the remains of two or three species of brachiopods.

The presence of the occipital spine distinguishes this cranidium from other American species of this genus. Bronteus haidingeri Barrande, from the Silurian of Bohemia, bears a similar occipital spine but differs in many other respects. The pygidium is almost identical with that of Thysanopeltis (Bronteus) 'tullius (Hall) from the Tully limestone of Onondaga county, New York, but it differs from the latter in having a pustulose axis, a constriction of the postaxial segment and a smooth margin. Thysanopeltis tullius bears spinules on the margin.

The cranidium and pygidium are here referred to the same species because of their association stratigraphically and because no other trilobite has ever been found in these beds.

In the University collection there is also another much larger pygidium which is very similar in proportions to $G$. thomasi. It is fairly well preserved and shows pustules on the axis and pleural segments though not quite as many as in, the type. It was found by Professor Calvin along Turkey creek, near Iowa City, associated with two specimens of Phacops rana on the same slab of limestone. The exact horizon is unknown, but judging from the locality given, it occurs either a few feet above or below the Wapsipinicon-Cedar Valley formation contact. This pygidium is tentatively referred to $G$. thomasi until more material is found to establish it definitely. 
This species is of peculiar interest because stratigraphically it comes from the uppermost and latest Devonian beds in the state of Iowa, beds which are roughly equivalent to the Portage beds of New York. The writer takes great pleasure in naming this species in honor of Doctor Thomas, who collected the specimens and placed them at the writer's disposal for study.

\section{Family PROETIDAE}

Proexus Prouti Shumard

Plate XXV, figs. 5-8.

1863. Proetus prouti Shumard, Trans. St. Louis Acad. Sci., vol. II, no. 1, p. 110. Devonian, a short distance north of Davenport, Iowa.

1878. Proetus davenportensis Barris, Proc. Davenport Acad. Nat. Sci., vol. II, p. 287, pl. XI, fig. 8. Corniferoùs formation at Davenport. This is the Upper Davenport formation.

1888. Proetus prouti Hall and Clarke, Pal. New York, vol. VII, p. 126, pl. XXIII, figs. 16 to 18. Cooks Quarry, top of Upper Davenport formation, Davenport.

Description.-Body subelliptical to suboval in outline, surface moderately convex transversely, trilobation distinct, length to width across the center of the thorax as 2 to 1 . In a well preserved specimen the ratio is probably as 3 to 2 but in the specimen at hand the pleuræ on the right side are compressed.

Cephalon subsemicircular, moderately convex, slightly produced and sharply rounded in front. Posterior margin arched, transverse, genal angles produced posteriorly into medially grooved spines which spread slightly and reach a point opposite the seventh segment. Border wide, flattened, bearing an outer and an inner groove separated by a low but distinct ridge. The outer groove is larger anteriorly and is bounded by a slightly recurved edge in front of the glabella. The inner groove is wide along the cheeks but narrow in front of the glabella. The length is to the width as 7 to 12 .

The facial sutures spread abruptly in front of the eyes to the outer marginal furrow thence curve inward and forward to the front margin. 
Glabella longer than wide, subconate, elevated, gently depressed convex, widest opposite the eyes, somewhat contracted in front, and ending narrowly rounded at the inner marginal groove. There are three pairs of lateral glabellar furrows visible on the translucent calcite. The first and second pair are short, subparallel and directed obliquely inward and backward. The posterior pair is much larger and bifurcates so that one arm of each is directed across the glabella and the other back toward the occipital groove. Occipital lobes prominent, transversely elongate-oval. Occipital segment strongly arched; furrow narrow medially, bifucating around the occipital lobes, wider on the free cheeks and continuing irito the genal spines.

The eyes are not well preserved in the specimens at hand. According to Hall (p. 127, 1888) "the eyes are moderately large, lunate; orbital ridge depressed and strongly sulcate at its base. Palpebral lobe large and closely appressed against the glabella; palpebral sulcus narrow and elevated."

The free cheeks are large, elevated, depressed around the base of the eyes, sloping moderately to the broad, shallow inner marginal sulcus.

Thorax distinctly trilobate, composed of ten segments, subquadrate, sides gently rounded and tapering gradually toward the pygidium. Axis raised, strongly rounded to semi-cylindrical, decreasing uniformly in size toward the pygidium. Width of axis slightly less than one-third that of thorax. Pleuræ flattened near the axis, thence sloping in a curve to the margin. Each segment is flattened and conspicuously grooved medially, giving rise to a wide fulcral fold which becomes obsolete on the sloping side. In places where the test has been removed each segment shows a low, sharp diagonal ridge at the fulcrum.

The pygidium is subsemicircular in outline, wider than long. The margin is gently thickened, inclined, and bears a very narrow outer sulcus near the edge and a broader shallow sulcus proximally. The axis is semiconate, narrow, tapering abruptly to an obtuse termination well within the margin. It is composed of ten annulations which are directed forward along the sides but cross the median area in a gentle posterior curve, Segments one to six 
bear conspicuous median nodes which decrease in size posteriorly. The pleuræ are gently convex, bearing from seven to eight annulations, which end at the border. Each annulation is marked by a fine median groove, which increases in size proximally and distally from the center.

Surface markings.-The entire surface, except the sulci, is covered with fine pustules or granules, which are readily visible upon the glabella. A small median node or tubercle is present on the occipital segment and according to Hall "the last four or five segments of the thorax each bears a strong tubercle in the axial line". This last feature is not shown in our specimen because it is partly exfoliated.

Measurements of specimen number 9089.-Length of body 42 $\mathrm{mm}$., width of same $24 \mathrm{~mm}$., length of cephalon $14 \mathrm{~mm}$., length of pygidium $13 \mathrm{~mm}$.

Positions and localities.-Specimen 9089 is from the Upper Davenport beds at Davenport (Prof. William H. Norton). The species occurs also in the Cedar Valley formation; in the Acervularia profunda zone, Brandon (M. A. Stainbrook); in the Cedar Valley formation, Iowa City, and at Packard's quarry, Johnson county.

Remarks.-The above specimens agree in all respects with those described by the above cited authors except that the axial tubercles were not mentioned by them. The specimen described by Shumard was somewhat abraded so that the tubercles were not preserved and such may also have been the fate of the specimens described by Barris and later by Hall. Similar tubercles are mentioned by Hall as occurring on the pygidium of Proetus rowi up to the third segment. Since this latter species has a pygidium which is so similar in many respects to $P$. prouti only careful discrimination will separate the two species. A number of pygidia from this vicinity, as well as the one from Davenport, which is in conjunction with the rest of the body, show at least six axial tubercles on the pygidium as opposed to three on $P$. rowi.

Associated with $P$. prouti is a very interesting history. The original specimen, which was described but not figured by Shumard, was destroyed during the great fire at St. Louis. In 1878 
Barris described and figured Proetus davenportensis from a complete specimen found in the Upper Davenport beds at Davenport. This specimen, according to Barris, was presented to the Davenport Academy of Sciences. Subsequently Barris loaned it and one other specimen to Hall who identified them with $P$. prouti and redescribed them under that name as cited above.

In the vicinity of lowa City detached parts of this species are commonly found in association with Proetus searighti, Conocardium altum and Cranaena iowensis.

Proetus nortoni $\mathrm{n}$. $\mathrm{s}$.

Plate XXV, figs. 9-11.

Description.-General form ovate-elongate to subelliptical. Surface equally and distinctly trilobate. Length is to width as 3 to 2.

The cephalon is semielliptical in outline, strongly produced in front of the glabella; width is to length as 5 to 3 . The border is broad, thickened, recurved, rounded at the edge and produced at the genal angles into stout spines which extend to the seventh thoracic segment. Within the thickened margin there is a prominent groove which is widest anteriorly and shallower toward the genal angles. The surface is depressed convex. The glabella is elongate subconate, very little longer than wide, gently arched transversely, the anterior half curved downward toward the submarginal groove but not extending fully to it. The glabella tapers abruptly to the narrowly rounded anterior extremity from a constriction opposite the anterior margin of the eyes. Three pairs of glabellar furrows are distinctly shown. They are subparallel to each other and directed obliquely backwards. The first pair is shortest, the second somewhat longer and the posterior pair is continued to the occipital groove so as to divide the posterior margin into three equal parts. The occipital lobes are moderately strong, having the form of an equilateral triangle with one of its bases paralleling the occipital groove. The occipital segment is broad, strongly arched transversely and gently rounded longitudinally, bearing a low but distinct tubercle in the axial line. The occipital groove is moderately deep and narrow 
throughout, scarcely widening on the cheeks. The dorsal furrow is represented in front and on the sides of the glabella by a narrow impressed groove.

The facial sutures are normal. They begin at the posterior margin one-third the distance from the outer edge and are directed diagonally across the thickened posterior margin of the cheeks toward the dorsal furrows back of the eyes. In front of the eyes they diverge abruptly and approximate again on the frontal margin. The palpebral Jobes are prominent and gently arched transversely. The eyes are lunate, narrow-elongate, rising almost vertically from a low orbital ridge nearly to the level of the glabella. The free cheeks are gently depressed along a narrow zone about the base of the orbital ridge and thence curve abruptly downward over a narrow lateral area to the submarginal groove. The outer thickened rim and the nearly equally thick posterior margin are continued at the genal angles into the long, stout, rounded spine.

The thorax is composed of ten segments and is subrectangular and nearly twice as wide as it is long. The sides taper gently. The axis is strongly arched transversely; width at the anterior end is equal to one-third the width of the thorax. It tapers gradually but more abruptly than does the thorax. The segments are . flattened, transverse and separated by narrow shallow grooves. The pleural lobes are flattened for two-thirds their width away from the axis, whence they bend abruptly downward to the margin. The segments are gently rounded to flattened throughout, there being no appreciable flattening distally but rather a transverse thickening at the outer margin; each bears a groove, in front of which there is a fulcral fold which becomes obsolete in a short distance on the sides.

The pygidium is semielliptical in outline and slightly emarginate behind. The width is to the length as 5 to 3 . The surface is moderately convex. The border is conspicuously thickened and bounded proximally by a shallow groove. The axis is raised above the pleural lobes, well defined by shallow dorsal furrows, gently arched longitudinally; less than one-third the total width at the anterior end, tapering gradually to an obtuse termination 
at the submarginal groove. Segments fourteen, flattened to gently rounded transversely. The intersegmental grooves are narrow. Pleural lobes moderately convex, sloping for some distance gently away from the axis, thence abruptly downward to the border. Segments ten, all but the last distinctly defined. They are flattened and extend to the submarginal groove, except the first three, which become obsolete on the border. Segments one to four bear an indistinct sulcus proximally and a short submedian groove distally. This latter groove is not well shown on the fourth segment.

Surface markings.-The surface of the glabella, except along the furrows, is covered with numerous low rounded pustules which differ in size but in general are smaller toward the margin. Similar but smaller pustules are borne on the occipital lobes and the occipital segment. Faint or nearly obsolete pustules are present on the cheeks. Each of the axial segments of the pygidium. bears a row of indistinct pustules. The thickened marginal rim of the cephalon bears impressed grooves.

Dimensions. - Length of body $32 \mathrm{~mm}$., width across genal angles $20 \mathrm{~mm}$., length of head $12 \mathrm{~mm}$., length of glabella $7.5 \mathrm{~mm}$., length of pygidium $10 \mathrm{~mm}$., width of same $15 \mathrm{~mm}$.

Position and localities.-The type specimen, No. 9095, is from the Upper Wapsipinicon beds, at Linn Junction, along the abandoned Chicago, Milwaukee and St. Paul Railway cut. It was collected by Dr. William H. Norton. A nearly perfect eranidium, No. 9098, preserving well the surface markings, was collected at this same locality by Mr. Tohn E. Adams. This specimen is a paratype of this species. A nearly complete specinen, No. 9094, was collected close to the top of the Upper Wapsipinicon beds at Janesville, Towa, by Professor Norton. It occurs also at Cedar Rapids and Solon.

Remarks.-The striking surface markings of the glabella, the continuation of the posterior lateral glabellar furrows to the occipital furrow, the long stout genal spines and the distinct segmentation of the pygidium distinguish this species from any other Iowa Proetus. In general outline of body and form of glabella it bears some resemblance to $P$. haldemani and it has been re- 
ferred to that species in the county reports, but the genal spines and the surface markings readily distinguish the two species. Proetus nortoni is named in honor of Professor Norton, who collected the type specimen.

Specimen No. 9094 shows well the surface markings on the cheeks. A separate pygidium, No. 9101, collected by Professor Norton at Janesville, is here referred to this species because of its close similarity to the type, from which it differs in but one respect, that of having sixteen instead of fourteen axial segments and twelve instead of ten pleural segments. This difference may be due to its larger size. The axial segments of this specimen show the surface markings unusually well. The entire specimen, No. 9102, shows eighteen axial segments and twelve pleural segments in the pygidium.

\section{Proetus clakus Hall}

Plate XXV, figs. 12-13.

1861. Proetus clarus Hall, Description New species of Fossils, p. 71. Upper Helderberg, N. Y.

1862. Proetus clarus Hall, Fifteenth Rept. New York State Cab. Nat. Hist., p. 99.

1876. Proetus clarus Hall, Illustrations of Devonian Fossil Crustacea, pl. XX, figs. 12-14.

1888. Proetus clarus Hall, Pal. New York, vol. VII, p. 104, pl. XX, figs. 12-14; pl. XXII, figs. 28-30.

Description.-Cephalon subelliptical to semicircular in outline, rounded in front, the eren contour being somewhat broken by a slight protrusion of the cranidium; border continued posteriorly on each side into a short genal spine which extends approximately to the fourth thoracic segment. Posterior margin strongly arched and describing a gentle curve forward. The surface is highly convex. Length is to width as 1 to 1.5.

Glabella conate, gently rounded transversely, arched longitudinally, widest opposite the palpebral lobes, constricted at the anterior angles of the eyes, thence narrowing anteriorly, and ending in an evenly rounded frontal extremity. Length equal to width. Three pairs of glabellar furrows can be faintly distin- 
guished upon the surface by a darker coloration of the calcite and the complete absence of pustules or granules on them. The first pair is short, rising opposite the anterior angles of the eyes, directed inward for two-thirds its length, thence obliquely backward. The second pair is longer, rises at the constriction of the glabella, and is directed obliquely backward. The third pair has its origin opposite the center of the palpebral lobes, is directed inward and thence abruptly backward, thus delimiting subrectangular basal glabellar lobes. The occipital lobes are well defined by deep grooves. The occipital segment is moderately broad. The occipital furrow is deep and narrow, increasing in depth on the cheeks. The surface of the glabella and the occipital lobes is marked by minute pustules which are larger posteriorly.

The eyes are large, semilunar,' strongly elevated above the cheeks and closely appressed against the glabella. The palpebral lobes are small.

The cheeks are prominent, raised proximally and approaching the suborbital ridge along a gentle slope; abruptly descending laterally to the well-defined marginal groove within the prominent flattened border.

Since neither thorax nor pygidium has been preserved in our specimen Hall's description (1888, p. 105) of those parts is copied here. "Thorax subrectangular, lateral margins slowly approximating posteriorly. Length to width as 2 to 1 .

Axis broad and strongly arched, width upon the anterior margin more than one-third the width of the thorax. Sides evenly approximating to the pygidium. The segments are flattened, transverse, or with a slight forward curve toward the axial line.

Pleuræ flattened near the axis, and at about one-third their width deflected in a more or less abrupt curve to the margins. Pleural annulations grooved, the anterior limb of each becoming rapidly obsolete beyond the fulcrum.

Pygidium.-Posterior outline the are of a circle whose center is the middle point of the body; when slightly compressed it is distinctly' emarginate at the posterior extremity; border broad, moderately thickened. Length about one-half the width.

Axis convex and slightly arched longitudinally; tapering to a broad, blunt termination just within the margin. Width equal to one-third the width of the shield. The sides are appressed just above the axial furrows, by a series of oblique impressions, one 
upon each annulation. From seven to eleven annulations may be counted upon the axis, the first five having an anterior inclination near the margins, and a posterior curve over the median region; the posterior annulations are transverse.

The pleuræ are depressed and curve evenly in all directions to the margins. They bear four annulations and traces of a fifth, and these are marked by fine impressed lines. All the annulations become obsolete upon the border, the articulating ring, however, encroaching upon it." Description modified after Hall 1888.

Dimensions of specimen 9090.-Length of cephalon $11 \mathrm{~mm}$., width of same $17 \mathrm{~mm}$.

Position and locality.-OUpper Davenport beds, Davienport (Dr. William H. Norton).

Remarks.-Proetus clarus is considered by Hall to be one of the most abundant species of the genus Proetus in the Upper Helderberg of the east but it is extremely rare in Iowa. However, considering the geographical distance as well as the large time-break between the Upper Helderberg and the base of the Upper Devonian it is rather surprising that it should be found in Iowa at all. It has many points of similarity with $P$. rowi but can be distinguished from the latter by having relatively larger eyes, a less broadly rounded glabella anteriorly, smaller and more sharply defined occipital lobes, and somewhat differently directed basal glabellar furrows.

This species was first recorded by Norton in the Geology of Scott County, Iowa Geological Survey, volume IX, page 450 .

\section{Proetus Rowi (Green) \\ Plate XXV, figs. 14-15}

1838. Calymene rowi Green, Amer. Journ. Sci. and Arts, vol. XXXIII, p. 406.

1861. Proetus rowi Hall, Descr. New Species of Fossils, p. 75.

1862. Proetus rowi Hall, Fifteenth Rept. New York State Cab. Nat. Hist., p. 103.

1876. Proetus rowi Hall, Illustrations of Devonian Fossils, pl. XXI, figs. 2-6.

1888. Proctus rowi Hall, Pal. New York, vol. VII, p. 119, pl. XXI, figs. 2-6, 24-26; pl. XXIII, figs. 20-29. 
1911. Proetus rowi, Cleland, Wisconsin Geol. and Nat. Hist. Surv., Bull. No. XXI, p. 142, pl. XLIV, fig. 1.

Description.-Body ovate in outline. Surface strongly but subequally trilobate, anterior and posterior margins broadly rounded. Length is to width as 1.5 to 1 .

Cephalon subsemicircular in outline; strongly convex and bearing a moderately wide, flat border. Glabella very large, convex, broadly conate, longitudinally arched, somewhat expanded opposite the palpebral lobes, slightly constricted opposite the anterior angles of the eyes, and broadly rounded in front. Posterior margin gently oblique at the angles and curved forward medially. Length greater than width. Lateral furrows represented by three pairs of smooth, inconspicuous linear impressions. The anterior pair is short and directed obliquely forward. The second pair is somewhat longer, situated opposite the anterior angles of the eyes, and directed gently backward. The third or posterior pair is largest, extending a short distance inward and thence bifurcating, one arm being directed across and the longer arm continuing toward the posterior margin of the glabella. The surface is marked by faint, nearly obsolete pustules. A number of larger pustules are closely aggregated centrally at the base of the glabella to form a low inconspicuous tubercle. A short distance on either side of this tubercle there are groups of three or four small pustules. The occipital lobes are prominent, transversely suboval to triangular, encroaching faintly upon the postero-lateral angles of the glabella. The occipital segment is broad, flattened and strongly arched. The occipital furrow is deeply impressed centrally, shallow around the occipital lobes and deeper again upon the cheeks. Palpebral lobes prominent, flattened, elongate.

Eyes large, lunate, closely appressed against the posterior half of the glabella, raised on a high orbital ridge but not attaining the height of the glabella. Visual surface strongly convex. Fixed cheeks narrow and extended into postero-lateral limbs which end approximately midlength of the posterior margin of the free cheeks.

Free cheek elevated proximally and bearing a broadly rounded suborbital groove; sides sloping abruptly to the margin. The 
border of the cheeks is not preserved in our specimen but according to Hall (1888, p. 120) "the border is unusually wide and carries two parallel grooves, the outer of which is marginal, producing a beveled edge; the inner broad and shallow, becoming flat in old individuals. On the posterior border the margin is also beveled, and the genal spines are strongly ridged by the meeting of these beveled edges." The median half of the suborbital groove is marked by a series of faint radiating grooves and ridges.

Thorax subrectangular with sides gently rounded; composed of ten segments. Length is to width as 2 to 3 . Axis strongly rounded, elevated above the pleuræ, tapering gradually toward the pygidium. Width greater than one-third the total width of the thorax. Segments transverse, gently rounded to flattened and separated by well-defined grooves. The dorsal furrows are not impressed. Pleural lobes flattened above for about one-half their width, thence sloping abruptly to the margin. The proximal two-thirds of each segment is deeply suleate, giving rise to a sharp, trigonal fulcral fold. The posterior margin of each segment is marked by a row of minute tubercles or granules.

The pygidium of our specimen is so poorly preserved that for the sake of accuracy and completeness Hall's description (1888, p. 121) is taken verbatim: "Pygidium subsemicircular or subsemielliptical in outline, faintly and broadly emarginate behind; length to width as 1 to 2 ; surface depressed convex.

Axis broad on the anterior margin; width equal to one-third the width of the shield; arched and sloping to a termination within the posterior border, a low ridge connecting the apex of the axis with the margin; composed of nine or ten low, flattened annulations, which have a forward inclination for about one-fourth their width from the axial margins and pass over the median area in a gentle posterior curve.

Pleuræ gently depressed, bearing six annulations with indica- . tions of a seventh, which are low, flat and faintly sulcate, becoming obsolete at or near the margin. The border is conspicuously thickened and moderately broad."

Concerning the surface markings of the axis Hall states that "there are usually indications of a row of faint axial tubercles beginning" at the occipital ring, omitting the first six thoracic seg- 
ments, thence recurring and extending to the second or third annulation of the pygidium." (Hall, 1888, p. 121.) This latter feature is not shown on our specimen because of abrasion of the axis.

Position and locality.-Upper Davenport beds, Davenport (Prof. William H. Norton). Specimen number 9129.

Remarks.--For the present Proetus rowi must be considered as one of the rare trilobites in this state. The only previous record of this species is in the Geology of Scott County (Iowa Geol. Survey, vol. IX, p. 451) where Norton has recorded it with the fauna of the Upper Davenport beds. The University collection contains only the somewhat mutilated specimen described above and it is hoped that more and better material will soon be found so that a complete record can be made which will link up this western form with that found in the Devonian of Wisconsin and in the Hamilton of the east. The much broader glabella, larger eyes, shorter genal spines, and the median tubercle at the base of the glabella distinguish this species from $P$. prouti.

\section{Proetus occromens Hall}

Plate XXV, figs. 16-17.

1861. Proetus occidens Hall, Descriptions New Species of Fossils, p. 80. Hamilton Group, New Buffalo, Towa.

1862. Proetus occidens Hall, Fifteenth Rept. New York State Cab. Nat. Hist., p. 108.

1876. Proetus occidens Hall, Illustrations of Devonian F́ssils, pl. XXI, figs. 22, 23.

1888. Proetus occidens Hall and Clarke, Pal. New York, vol, VII, p. 130, pl. XXI, figs. 22, 23.

The following is a copy of the original description by Hall (1861).

"This species, so far as known, is represented by only two somewhat imperfectly preserved pygidia. Their outline is semielliptical; length to width as 3 to 4 ; surface depressed convex. The axis has a little less than one-third the width of the shield on the anterior margin, is moderately convex and tapers evenly to an obtuse apex which lies just within the conspicuous marginal border. It bears about twelve transverse annulations. The lateral slopes are gentle and bear nine or ten flattened annulations, 
each of which appears to be faintly sulcate. Surface minutely granulose. The larger of the two specimens measures $18 \mathrm{~mm}$. in length and $23 \mathrm{~mm}$. in width; the smaller $14 \mathrm{~mm}$. in length and 18 mm. in width. This species has proportions similar to those of Proeius macrocephalus, but has fewer annulations and lacks the conspicuous ornamentation of that species.

Distribution. Hamilton group. New Buffalo, Iowa."

Remarks.-While collecting in the type locality at Buffalo, Scott county, Iowa, the writer found two pygidia, the general outline, proportions, number of annulations, and surface markings of which answer the above description. Associated with these pygidia there was also a cranidium which is, however, so fragmentary and incomplete that its specific characters have been lost. But because of its association and the great scarcity of other trilobite material in this horizon this specimen is tentatively referred to this species.

All three specimens were found in a thin layer of bluish green shale interbedded between layers of massive crystalline limestone. They are numbered 9125, 9126, 9127.

Position and locality.-Upper Davenport beds, Buffalo quarries, Buffalo (same as New Buffalo of Hall).

\section{Proetus haldemani Hall}

Plate XXV, figs. 18-19.

1861. Proetus haldemani Hall, Descr. New Species of Fossils, p. 74. Hamilton formation.

1862. ' Proetus haldemani Hall, Fifteenth Rept. New York State Cab.. Nat. Hist., p. 102.

1876. Proetus haldemani Hall, Illustrations of Devonian Fossils, pl. XXI, fig. 7-9.

1880. Dechenella haldemani Kayser, Zeitschr. d. deutsch. geol. Gesellsch., Jahrg., p. 707, pl. XXVII, fig. 9.

1884. Proetus haldemani Walcott, Monog. U. S. Geol. Survey, vol. 8, Pal. Eureka Dist., p. 210.

1888. Proetus haldemani Hall, Pal. New York, vol. VII, p. 113, pl. XXI, figs. 7-9; pl. XXIII, figs. 13-15.

Description.-General form ovate-elongate. Surface distinctly and equally trilobate. Length is to width about as 3 to 2 .

Cephalon semicircular in outline ; border broad, flat and abrupt- 
ly sloping at the edge, widest in front of the glabella, gradually narrowing toward the genal angles. Submarginal groove narrow in front, wider and shallower posteriorly. Glabella conate, wjdest across the base, thence tapering gradually to a narrow rounded anterior extremity except for a slight expansion opposite the palpebral lobes. Greatest width slightly greater than the length. Surface depressed convex; the anterior third abruptly curved downward as a rule though some specimens show but a slight curvature. There are three pairs of well defined lateral glabellar furrows, all of which curve obliquely backward. The first pair is rather short, the second pair somewhat longer and more obliquely inclined, the third pair is longest, passing obliquely inward and thence abruptly backward toward the posterior margin but opening into the occipital furrow. Occipital lobes small and inconspicuous, tapering inwardly. Occipital segment broad and flattened, narrowing toward the dorsal furrows; a minute tubercle is located medially on the posterior margin. Occipital furrow narrow and shallow throughout. Palpebral lobes prominent, extending horizontally outward from the shallow dorsal furrows.

Eyes of medium size, narrow, lunate, raised on a well defined orbital ridge to the height of the glabella.

Free cheeks depressed convex, rising gently from the shallow marginal furrow to the shallow depression at the base of the orbital ridge. Genal angles faintly produced but not forming spines.

Thorax subrectangular; composed of ten segments. Axis broadly rounded transversely, distinctly elevated above the pleuræ; tapering uniformly toward the pygidium. Segments flattened, smooth, transverse and separated by well-defined but narrow and shallow grooves. Pleuræ gently sloping to flattened for about one-half their width, thence sloping in a more abrupt curve to the margin. Segments flattened and bearing a short narrow sulcus across the fulcrum, thus delimiting a narrow trigonal fold.

Pygidium subelliptical in outline, gently convex over all. Border faintly thickened, moderately wide on the sides, increasing in width posteriorly and sloping in a plane with the convex- 
ity of the surface. Axis low but well defined throughout, gently rounded transversely and tapering to a narrow rounded extremity at the border; composed of twelve to fourteen flattened annulations which are transverse across the center but slightly oblique at the sides. The pleural lobes slope gently from the axis to the border and bear eight to ten smooth flattened annulations of which the first three are bifurcate distally and end on the border whereas the others end at the border. One specimen from which the crust has been removed shows a faint median sulcus to each pleural segment.

Surface markings.-The surface of the entire test and especially that of the glabella is covered with very ininute punctæ.

Dimensions.--Specimen 9092, a rolled-up form. Length of body measured along curvature $27 \mathrm{~mm}$., length of cephalon 8 $\mathrm{mm}$., length of thorax $11 \mathrm{~mm}$., length of pygidium $7.5 \mathrm{~mm}$. Width across genal angles $13 \mathrm{~mm}$. Specimen 9093, a cephalon, has a length of $12 \mathrm{~mm}$. and a width of $25 \mathrm{~mm}$.

Position and localities.-Upper Davenport beds, one-half mile north of Elmira, Johnson county (Leroy P. Elliot) ; Linn Junction.

Remarks.--This species is so distinctive that it is not likely to be mistaken for any other species of Proetus. The glabella bears a superficial resemblance to Proetus nortoni in general outline and arrangement of lateral furrows but the posterior furrows of the former do not open into the occipital furrow as they do in the latter and the surface of $P$. haldemani is smooth while that of $P$. nortoni is always strongly pustulose.

Proetus aribatinus $n . s$.

Plate XXV, figs. 21-22.

Description.-Body ovate or subelliptical in outline, broadly rounded anteriorly, more sharply rounded posteriorly. Surface strongly but subequally trilobate. Length is to width as 1.6 is to 1 .

Cephalon subsemicircular in outline, posterior margin arcuate; border very narrow, forming almost a linear ridge and bearing an equally narrow and shallow marginal sulcus. The cephalon is 
disposed nearly at right angles to the long axis of the body. The facial sutures appear to be normal and widely separated on the frontal margin. Glabella large, moderately and evenly convex, subquadrate to semiovoid in outline, narrowing somewhat anteriorly. Length slightly greater than width across the palpebral lobes. Evidence of any glabellar furrows is entirely wanting either on the normal or exfoliated specimens. Occipital lobes present as low moderately well defined nodes. Occipital segment broad medially, narrowing laterally. Occipital furrow and dorsal furrows narrow and shallow. Dorsal furrow is continued around the anterior end of the glabella as a distinct groove.

Fixed cheeks very narrow immediately anterior and posterior to the palpebral lobes. Palpebrum small, elongate and suberescentic in outline. The surface of the glabella is marked by faint, transverse, lamellose lines.

Free cheeks depressed at the summit about the base of the orbital ridge, thence sloping abruptly to the margin. The poor state of preservation makes it impossible to determine the presence or absence of genal spines.

The eyes are of medium size, slightly elevated but not attaining the height of the glabella.

Thorax subquadrate; length is to width as 2 to 3 ; margins nearly parallel; surface subequally trilobate. Axis prominent, broad, elevated above pleural lobes, evenly rounded and tapering regularly backward. Width nearly one-half that of thorax. Segments flattened, transverse. Pleural lobes flattened for a little less than one-half their width, thence sloping moderately to the margin. Each segment is flattened and grooved for two-thirdis its length, giving rise to a relatively broad fulcral fold.

Pygidium semielliptical in outline; length is to width as 3 to 4 . Axis very prominent, evenly rounded transversely, arched longitudinally, elevated above the pleuræ and tapering regularly to a narrow termination near the margin. Width greater than onethird the width of the shield at the anterior margin. Pleural lobes narrow, sloping along a gentle curve from the axis to the margin. Owing to the poor state of preservation a more specific description is impossible at the present time and other pygidia 
which may belong to this species can not be positively referred to it until a well preserved pygidium is found in conjunction with the rest of the body.

Dimensions of specimen 9122.-Length of cephalon as measured along the median curvature $15 \mathrm{~mm}$.; length of thorax 13 $\mathrm{mm}$.; length of pygidium $12 \mathrm{~mm}$.; greatest width across genal angles $19 \mathrm{~mm}$.

Position and localities.-Cedar Valley formation, Iowa City and Brandon; Upper Wapsipinicon, Linn Junction.

Remarks.-Proetus arietinus is described from a poorly preserved complete specimen and from two well preserved cranidia. It differs markedly from other members of this genus in the peculiar disposition of the strong convexity of the head, almost at right angles to the axis of the body, and in having an 'exceptionally narrow border about the cephalon. Another distinguishing character is the wide and prominent axis of the thorax and the pygidium. It differs from $P$. bumastoides in having occipital lobes, a broader occipital segment and a more conate glabella anteriorly. From Proetus searighti it can be distinguished by the much narrower frontal border.

\section{Proetus searighti $n . s$. \\ Plate XXVI, figs. 1-9.}

Description.-Cephalon semicircular in outline, globose, highly convex both transversely and longitudinally, border moderately wide, concave and slightly recurved in front, wider and nearly horizontal near the genal angles. Length is to width as two is to three.

Glabella conate, strongly convex, longer than wide, sloping in all directions from the axial line; sides slightly constricted opposite the palpebral lobes, thence tapering in a gentle outward curve to a narrow rounded anterior extremity which encroaches upon the marginal sulcus. Three pairs of glabellar furrows are very faintly outlined in both entire and exfoliated specimens. The first and second pairs are short and subparallel and rise within a short distance of each other opposite the anterior angles of the eyes and are directed obliquely backward. The third pair 
begins opposite the center of the palpebral lobes posterior to the second pair at a distance equal to twice that between the first and second pair; they are directed along a zig-zag path toward the occipital groove but do not open into it. A short pair of accessory furrows (best seen in 9105) is present between the third pair of lateral furrows. The surface of the glabella is marked posteriorly by low rounded pustules which give place anteriorly to narrow elongate pustules and finally to interrupted ridges and dashes. All trend in the same direction across the glabella. The occipital segment is marked by a strongly transverse arch, which is broad medially, but narrower laterally and bears a median node and minute pustules on the posterior margin. The occipital lobes are of moderate size, transversely oval and covered with minute pustules. The occipital groove is narrow, raised and shallow.

The free cheeks are strongly raised proximally, broadly depressed about the prominent occular ridge, thence sloping very abruptly to the shallow marginal sulcus; outer edge thickened, vertical and appressed against the nearly horizontal border. The surface is marked by small pustules and the descending vertical edge by lamellose lines.

The eyes are small, rounded, prominent and raised on a conspicuous orbital ridge.

Thorax unknown.

The pygidium is semielliptical in outline,. strongly convex and equally trilobate; border broad, thickened, abruptly sloping on the sides and nearly vertical posteriorly. Axis strongly rounded transversely, arched longitudinally and gently depressed along the dorso-median area; tapering to a somewhat raised obtusely rounded extremity a short distance from the border; composed of thirteen to fourteen annulations which are directed forward laterally and are transversely to posteriorly curved medially. The annulations are flattened and separated by shallow grooves. Pleural lobes strongly convex, depressed near the axis and sloping abruptly on the sides to the border. Annulations eight to nine, the last two being indistinct; all are low, gently rounded and end at the border. Specimens retaining the crust show a 
faint median sulcus occasioned by two rows of small pustules on each annulation. Length is to width as two is to three.

Dimensions. - Cephalon (No. 9106), length 16 mm., width 23 . mm., height $8 \mathrm{~mm}$. Pygidium (No. 9109), length $11 \mathrm{~mm}$. , width $15.5 \mathrm{~mm}$. Pygidium (No. 9130), length $15 \mathrm{~mm}$., width $20 \mathrm{~mm}$.

Position and localities.-Cedar Valley formation, Iowa City (outcrops along Templin road and along Red Ball Route), Mid River, and Packard's quarry, Johnson county.

Remarks.-The preceding description is based on specimens Nos. 9105-9110, 9130 and 9131. Dismembered parts of this species are fairly common in the Cedar Valley formation in the vicinity of Iowa City and nearby points to the north. A complete specimen has not been found. Proetus searighti is distinguished from the other members of this genus by the characteristic surface markings of the glabella, the moderately wide upturned frontal border of the cephalon, the very small eyes, high cheeks and absence of genal spines. In general outline of cephalon it resembles $P$. crassimarginatus but the absence of genal spines on $P$. searighti will readily distinguish it from the latter.

Because of its common association with parts of the head the pygidium above described has been tentatively referred to this species. A final determination must, however, await the finding of a complete specimen. In general proportions and number of axial and pleural annulations it resembles the pygidium of $P$. crassimarginatus but no mention is made by Hall of granular surface markings and faint sulci on the annulations of the latter. This difference may serve to distinguish the two species.

The writer takes pleasure in naming this species in honor of $W$. $V$. Searight whose untiring efforts have been responsible for obtaining most of the material upon which the description is based.

Proftus bumastomes $n$. $s$.

Plate XXV, figs. 23-24.

Description.-The cranidium is comparatively short and wide and strongly arched longitudinally. The anterior outline is broadly rounded and slightly produced medially. The border is narrow and closely appressed against the glabella, forming a low 
but sharp ridge parallel to the narrow marginal sulcus and is thence deflected into a relatively broad flattened descending area whieh is marked by five or six subparallel linear ridges.

The glabella is subrectangular in outline, somewhat longer than wide, strongly arched longitudinally, gently rounded transversely. The anterior margin is broadly rounded, the posterior margin is transverse, the antero-lateral angles are obtusely rounded and the sides diverge gently toward the occipital groove. All lateral glabellar furrows are wanting. The surface markings consist of numerous minute, anastomosing, linear ridges having a general transverse trend approximately parallel to the anterior margin. These markings are more conspicuous on the anterior than on the posterior half. The posterior margin of the glabella* descends abruptly to the occipital groove. Occipital lobes wanting. The occipital segment is strongly arched, narrow and rounded above and still narrower on the cheeks. The dorsal furröws are shallow and raised opposite the palpebral lobes. The palpebral lobes are small, narrow elongate, lunate, close to the glabella, and extend horizontally outward from the dorsal furrows.

Free cheeks, thorax and pygidium unknown.

Dimensions of cranidium (No.9115).-Length $11.6 \mathrm{~mm}$., length of glabella $9.8 \mathrm{~mm}$., width of same at palpebral lobes $9.4 \mathrm{~mm}$.

Position and locality.-Cedar Valley limestone, at base of second outerop (abandoned quarry) north of the Park bridge, Iowa City:

Remarks. - This species is known only from a single cranidium which differs from the other members of this group in at least as many cranidial characters as those species differ from each other. The narrow descending frontal margin, the equally narrow marginal sulcus, the shallow dorsal furrows, small palpebral lobes, very broadly rounded anterior outline of the glabella as well as the bumastoid convexity and surface markings form a combination of characters which readily distinguish this from all other species of Proetidae. 
Proetus crassimarginatus Hall

1843. Calymerie crassimarginatus Hall, Geology of New York, Surv. of Fourth Geol. Dist., p. 172, fig. 5.

1888. Proetus crassimarginatus Hall, Pal. New York, vol. VII, p. 99 ; pl. XX, figs. 6-8, 20-31; pl. XXII, figs. 20-26; pl. $\mathrm{XXV}$, fig. 8 .

This species has been reported from the Upper Wapsipinicon beds and more particularly from the Upper Davenport stage at Davenport, by Norton in Iowa Geological Survey, volume IX, page 451, and again in the same publication, volume XXVII, page 54.t. The writer has lailed to determine definitely this species for Iowa. Pygidia have been collected from the Upper Wapsipinicon and the Cedar Valley formations in different parts of the state which are similar to that described by Hall. All these have been referred temporarily to $P$. searighti because to date no cephalon has been found which answers the description of $P$. crassimarginatus. With only dismembered parts for study it seems best to hold in abeyance any positive assertion concerning either the presence or absence of this species. Sooner or later an entire specimen may be found which will definitely dispose of this problem.

Proetus sp.

Plate XXV, fig. 20.

A fragmentary pygidium resembling Proetus (Phaethonides) gemmaeus Hall as represented by figure 33, Plate 24, Paleontology of New York, vol. 7, was found by the writer in the Upper Wapsipinicon beds at Linn Junction. The axis of this specimen has been completely destroyed and of the pleural lobes only a portion of the right one is perfectly preserved. The pygidium is semicircular in outline, having an entire outer margin. The pleuræ slope moderately from the axial region to the broad shallow concave border within a faintly upturned edge. The surface is marked by eight low, narrow but sharp ridges each of which is continued to the margin without any decrease in size and bears a row of low distantly spaced pustules on the crest. The ridges are' separated by very broad shallow grooves. The area bäck of the axis is smooth. 
The length of this specimen, No. 9104, is $6 \mathrm{~mm}$. and the width $9 \mathrm{~mm}$.

Remarks.-Until more complete material is found this specimen can not definitely be referred to any species.

Cyphaspis Raripustulosus n. $\mathrm{s}$.

Plate XXVI, fig. 11.

This species is represented by a very small fragmentary cranidium having the following characters: The area in front of the glabella is produced into a broad evenly concave groove having a thin recurved or upturned margin which reaches nearly to the height of the glabella. The facial sutures spread abruptly in front of the palpebral lobes. The glabella is moderately convex, semiovoid in outline, broadly rounded in front, transverse behind, sides spreading gently from the antero-lateral angles to the occipital groove. The length is equal to the width at the base. Two pairs of lateral furrows are directed obliquely backward; the antero-lateral pair is well defined but short; the posterior pair is longer, more deeply impressed, extending nearly to the occipital groove, and delimiting a pair of large subtriangular basal lobes. The occipital segment is broad, gently convex, strongly arched transversely. The occipital and dorsal furrows are shallow. The palpebral lobes are promthent.

Surface markings.-The entire surface is covered with numerous minute to microscopic punctæ which are largest on the frontal area. A few small, widely separated pustules are present on the frontal area immediately adjacent to the antero- lateral angles of the glabella, on the fixed cheeks opposite the glabella and on the basal lobes.

Imbedded in the same slab of limestone a few millimeters from the cranidium is a fragmentary free cheek which is characterized by a broad concave marginal groove similar to that comprising the frontal area of the cranidium. The lateral portion of the cheek is narrow, rises abruptly to the shallow suborbital impression and is marked by pustules similar to those on the cephalon. The eye is comparatively large, raised on a high orbital ridge 
and distinctly faceted. At the genal angle the cheek is produced into a broad. spine.

Dimensions.-Length of cephalon $5.5 \mathrm{~mm}$., length of glabella $3.3 \mathrm{~mm}$. Museum number 9113.

Position and locality.-Cedar Valley limestone, Mid River. Collected by M. A. Stainbrook.

Remarks.-This species bears some resemblance to Phaethonides varicella $\mathrm{Hall}^{17}$ in size and in possessing a broad concave frontal area with upturned margin, but the basal lobes of our specimen are much larger, the occipital segment is broader and the surface bears fewer and less regularly distributed pustules.

\section{CyPHASPIS BRANDONENSIS n. $\mathrm{s}$.}

Plate XXVI, fig. 12.

Description.-Cranidium moderately convex, anterior outline very gently rounded. Frontal area narrow, slightly. elevated near the glabella, thence sloping abruptly for about one-half its width to the narrow, deep marginal groove beyond which it is continued into a thickened, rounded border. Glabella prominent, evenly convex, subpyriform, longer than wide, elevated above the cheeks, bounded anteriorly and on the sides by the sharply impressed dorsal furrows, which are somewhat shallower opposite the basal lobes. The length of the glabella is slightly less than two-thirds the length of the cephalon. The basal lobes are pyriform, small but prominent, and separated from the glabella by narrow, deep lateral furrows which are directed posteriorly along a gentle curve and open into the occipital groove. The occipital segment is broad, strongly arched transversely, somewhat recurved medially, decreasing in breadth laterally, and bearing a conspicuous tubercle on the posterior margin in the axial line.

The facial sutures cut the anterior margin of the cephalon directly in front of the eyes and do not diverge appreciably as they pass forward. The fixed cheeks are narrow and raised, forming a low rim around the glabella.

Surface markings.-The surface of the glabella, basal lobes and occipital segment is ornamented by numerous closely set,

17 Hall, Pal. New York, vol. VII, p. 135, pl. XXIV, fig. 29. 
minute rounded pustules. The area adjacent to the dorsal furrows and the rounded frontal border are marked by fewer and smaller pustules.

The thorax and the pygidium are unknown but an incomplete thoracic segment occurs on the same slab of limestone near the cranidium. The axial portion of this segment is strongly arched transversely, occupying approximately one-third the total width. The pleura is very gently arched for two-thirds its width away from the axis and thence bends abruptly downward to the margin. The small size and general proportions of this segment as well as the close association with the cranidium constitute the basis for referring the specimen to this species.

Dimensions.-No. 9114, length of cephalon $3.3 \mathrm{~mm}$., length of glabella $2 \mathrm{~mm}$.

Position and locality.-Independence shale, Brandon (station 3). Collected by M. A. Stainbrook.

Remarks.-This species is of peculiar interest because it is the first trilobite ever recorded from the Independence shale of Iowa. In general outline and proportions it bears some resemblance to C. bellula Whiteaves, and also to C. ornata Hall. But it differs from the former in being much less convex and in having a narrower frontal area; and from the latter in having a narrow instead of a broad concave marginal groove. From both species it is readily distinguished in not having the single row of beadlike tubercles on the frontal border.

\section{Family PHACOPIDAE}

\section{Asteropyge barkisi (Hall) \\ Plate XXVI, fig. 18.}

1888. Dalmanites (Cryphaeus) barrisi Hall, Nat. Hist. New York, Paleontology, vol. VII, p. 48, pl. 16a, fig. 18.

The following is a copy of the original and only description of this species to date:

"Specimens of pygidia from the buff and drab Devonian limestones in the state of Iowa present certain peculiarities which will not permit their union with either of the foregoing species (Dalmanites (Cryphaeus) boothi Hall, and Dalmanites (Cry- 
phaeus) boothi var. calliteles (Hall). The general aspect of these caudal shields is quite similar to that presented by very young individuals of Dalmanites boothi var. calliteles, with the exception that in the latter the axial spine is scarcely developed, while in the Iowa species it is conspicuous and broader than any of the lateral spines. The lateral spines are long, round, slender and terete, with a gentle backward curve; slightly thickened at the base, and not elevated along the middle as in the New York species. They are also relatively much larger than in any adult specimen of the variety calliteles observed.

The axis of the pygidium tapers rapidly, and bears from six to eight annulations, which have a strong forward inclination in the middle.

All the specimens representing this species are small, but are of about the same size, and have undoubtedly attained their mature growth. The best preseryed of the specimens has a length of $8 \mathrm{~mm}$. to the extremity of the axial spine, a width of $9 \mathrm{~mm}$. along the anterior margin to the bases of the lateral spines; the length of the anterior spines is $5 \mathrm{~mm}$.

Distribution.-Hamilton group. In the limestones usually referred to this horizon near New Buffalo, and at Searstown and Iowa City, Iowa."

Remarks.--The above description is copied verbatim because we have no material for comparison or study. The species is here referred to the genus Asteropyge as defined in Zittel, page 726 .

\section{Asteropyge FITZPATRICKI n. s.}

Plate XXVI, fig. 19-21.

Description.-Pygidium small, subsemicircular in outline, distinctly trilobate, bearing a row of eleven comparatively long, slightly backwardly curved spines on the outer margin, which is broadly rounded. The width is one and one-half times the length exclusive of the spines. The axis is depressed convex, distinct throughout, gently rounded transversely, not arched longitudinally nor raised above the pleural lobes, tapering abruptly to a narrow rounded extremity and terminating one-half its anterior width within the margin. Annulations nine, the anterior six well defined and curved forward medially, the posterior three indistinct. The width of the axis at the anterior end is about one- 
fourth the total width of the pygidium. Dorsal furrows narrow anteriorly, wider posteriorly and ending in a shallow rounded depression at the postero-lateral angle of the axis. Pleural lobes depressed, gently rounded medially, marked by five strong segments which are increasingly oblique from front to back, the fifth being straight or directed slightly inward rather than outward. Each segment is continued into a strong inwardly curved marginal spine which is rounded proximally, flattened dorso-ventrally and spatulate distally. 'The spine of the fifth segment is clavate, being constricted proximally. The first two or three pleural segments are broad, flattened, bearing a median linear groove which extends from the dorsal furrow to a depression within the outer margin. The posterior half of the segment ends at this depression, the anterior half continues to the margin where it becomes abruptly expanded and thickened to form the base of the marginal spine. The fourth and fifth segments are rounded transversely and not divided longitudinally. The intersegmental grooves are narrow and shallow. Back of the axis there is a broad smooth zone which is continued into a short median terminal spine of nearly uniform size throughout. The marginal spines appear to decrease regularly in length from front to backs. The entire surface is smooth.

Dimensions.-Length including terminal spine $8 \mathrm{~mm}$., width exchusive of marginal spines $12 \mathrm{~mm}$., length of the anterior spine $3 \mathrm{~mm}$.

Position and locality.-Cedar Valley liniestone, Johnson county. Collected by Prof. T. J. Fitzpatrick, in whose honor the species is named.

Remarks.-The description is based on a single pygidium the characters of which are so different from any described species that it is here made the type of $A$. fitzpatricki. On comparing it with $A$. barrisi, a closely associated species, the following differences are observed. In $A$. barrisi all the segments of the pygidium, both axial and pleural, are subequally divided, the posterior part being narrow and smooth, the anterior part wide and bearing a median row of small tubercles; the terminal spine is V-shaped, having a broad base, and the submarginal depres- 
sions at the end of the first three pleural segments are wanting. In $A$. fitzpatriclii the surface is smooth, the axial segments are not divided, the pleural segments bear a median groove, and the terminal spine is slender and of nearly uniform width throughout.

Both of these species possess characters which relate them to divisions I and III of the Dalmanitinae as defined by Reed ${ }^{18}$. Division I, primarily Ordovician, is characterized by a pygidium having a smooth rounded outline and rarely more than ten axial segments: Division III, primarily Devonian, is characterized by a pygidium having many marginal spines and from sixteen to twenty axial segments. Our species, though having but few axial segments in the pygidium, must be referred to the Devonian genus Asteropyge of division $\amalg I$ because the spinose margin as well as the geological position must take precedence over the small number of segments. This would necessitate a revision of Reed's division III to include Dalmanitinae with as few as eight or nine axial segments in the pygidium.

The pygidium of the genus Dalmanites "is strongly mucronate, with 12-16 segments", therefore this name as used by Hall for his species barrisi should be dropped. The name Cryphaeus, which antedates Dalmanites, has been shown by Reed to be preoccupied.

During the spring of 1921 Miss Helen Nicholson collected a specimen of Asteropyge in the Wapsipinicon beds at Linn Junction. This specimen is incomplete, consisting of a fragmentary head and the last four thoracic segments in conjunction with an imperfect pygidium. The outline of the head is semicircular to lunate, with a broadly rounded outer margin and a re-entrantly curved posterior margin. The glabella is large and pentamerously segmented, the frontal lobe is transversely elliptical, its width greatly exceeding the length of the glabella. There are three pairs of well defined lateral lobes, which decrease abruptly in size from front to back. The anterior lateral glabellar furrows are longest and directed obliquely inward and backward; the second and third lateral furrows are nearly straight and all end equidistant from the median line of the glabella. The surface is dense- 
ly covered with short, stout tubercles. The dorsal furrows converge abruptly from the sides of the frontal lobe to the occipital segment. The palpebral lobes are located opposite the first and second lateral lobes and rise sharply from the dorsal furrow. The free cheek is large, strongly concave, rising sharply along an inward curve to the orbital ridge, and ending marginally in front of the eye. The eyes are large, reniform and raised above the cheeks and glabella. From the specimen it is impossible to tell whether cheek spines are present.

The thorax, represented by the last four segments only, is raised. The axis is prominent and elevated above the pleural lobes. Each segment is rounded, slightly swollen on either side, bearing a row of short, stout tubercles. The pleural lobes are convex, flattened above, and gently sloping at the sides. The anterior margin of each segment bears a narrow fulcral fold which extends from the dorsal furrow to the convexity. Minute tubercles are present on the surface.

The pygidium is incomplete, the terminal portion is entirely missing and of the marginal spines only the proximal part remains. In general appearance the preserved part is similar to A. fitzpatricki, but the number of axial segments is greater by three or four, the axis does not taper uniformly throughout its length, having nearly parallel sides from the sixth segment to the end, and all the segments are strongly pitted, each pit marking the base of a broken tubercle.

This specimen may very well prove to be a new species. But in the absence of entire marginal spines on the pygidium it is here tentatively included with $A$. fitzpatricki until more material will make possible an undoubted specific reference.

\section{Phacots rana Green}

\section{Plate XXVI, figs. 23-26.}

1832. Calymene bufo var. rana Green, Mon. Tril. North America, p. 42, casts 11,12 .

1844. Calymene bufo Owen, Geol. Expl. Iowa, Wisconsin, Illinois, p. 74, pl. 12, fig. 1.

1861. Phacops rana Hall, Description New Species Fossils, p. 65. 
1888. Phacops rana Hall, Pal. New York, vol. 7, p. 19, pl. 7, figs. 1-11; pl. 8, figs. 1-18; pl. 8a, figs. 21-33.

1888. Phacops rana Clarke, Jour. Morphology, vol. 2, p. 253, pl. 21.

For more complete bibliography see Vogdes, "Bibliography of Paleozoic Crustacea," 1893.

Description.-General outline elongate, subovate, anterior and posterior margins describing the arc of a large and small circle respectively. Sides of the thorax straight, subparallel, converging gently posteriorly. The length is to the greatest width across the genal angles as 2.2 to 1 .

The cephalon is strongly arched, subsemicircular in outline, slightly produced at the glabella and genal extremities. Posterior margin nearly straight within the genal angles. The glabella is large, convex, subpentagonal in outline, well defined laterally by deep diagonal dorsal furrows; greatest width in front of the eyes; antero-dorsal portion barely projecting over the margin. Two or three pairs of lateral glabellar furrows are present, opposite the eyes, in some well preserved specimens. Where present they appear as gentle, forwardly curved, linear depressions in the tuberculate surface. The posterior pair of furrows traverses the glabella, thus delimiting a narrow annulation in front of the occipital segment. Adjacent to each dorsal furrow this annulation forms a low node. The occipital segment is prominent, rounded, strongly arched transversely, and as large as the first thoracic segment. The occipital groove is narrow and shallow, becoming obsolete upon the cheeks posterior to the eyes. The free cheeks slope abruptly from the suborbital groove to the margin in a plane with the surface of the eyes. They are wide and rounded at the genal angles and narrower in front of the eyes. Ventrally the cheeks are infolded to form a doublure which bears a groove just below the margin. This groove is wider on the. epistoma beneath the glabella and toward the genal extremities it bears six crenulations. This latter character is seen only in favorably preserved specimiens.

The eyes are large and very prominent, reaching, nearly the height of the glabella. The visual surface is large, lunate and raised on a low occular ridge within a broad, shallow groove on 
the cheeks. The number of lenses differs according to the size and age of the individual. One small specimen has thirty-six lenses and a rather large specimen has ninety-three. The latter is a rather unusually large number for this species. The palpebrum is crescentic in outline and gently arched medially. The palpebral lobe is large and directed obliquely toward the dorsal furrow.

Facial sutures are not shown on any of the specimens at hand. Concerning these sutures Hall (Pal. New York, VII, p. 20) makes the following statement: "Facial sutures very rarely discernible. 'Occasional examples, in unusually perfect state of preservation and favorably weathered, or compressed in such manner as to slightly separate the cephalon along these lines, show that they take their origin on the lateral margins just in front of the genal angles, pass along the posterior edge of the visual area, thence forward along the margin of the palpebrum, following the frontal furrow of the glabella until they meet, thus taking the normal direction for the facial sutures in the Phacopidae. It is probable that the separate parts of the cephalon, in all stages of growth, are virtually anchylosed along these lines, as the cheeks are rarely, if ever, found detached."

The thorax is subquadrate, strongly trilobate and composed of eleven segments. The length is to the width as 11 to 9 . The axis is evenly convex, less than one-third the total width, widest across the third segment, thence tapering gently toward the pygidium. Each segment is strongly rounded medially and somewhat flattened laterally. The intersegmental grooves are wide and moderately deep. The pleural lobes are flattened above and abruptly deflected at about two-thirds their width from the dorsal furrows. The proximal two-thirds of each segment is rounded, giving rise to a well-defined fulcral fold which becomes obsolete a short distance upon the sides. At the fulcrum each segment curves slightly backward.

The pygidium is smaller than the cephalon, strongly convex, distinetly but subequally trilobate, semiovate to semicircular in outline in older specimens and transversely lentiform in younger specimens, bounded by two curved lines meeting at the anterolateral angles, of which the posterior line describes the more convex and uniform curve and is somewhat emarginate medially. 
The axis is strongly curved and gently arched longitudinally. In mature specimens it tapers abruptly posteriorly and ends in an acute termination just within the margin. In very young specimens it tapers very gradually and is obsolete before reaching the margin. Width equal to a little more than one-fourth the width of the shield. Depending on the age of the specimen, from seven to nine annulations may be counted upon the axis. In young specimens the annulations are obsolete after the seventh although the outline of the axis is still well clefined for some distance. AIl are transverse, strongly rounded and bear a row of short but distinct tubercles. The nonannulate posterior part of the axis of young specimens is covered with similar tubercles which lack, however, a definite arrangement. The pleural lobes are gently depressed near the axis, thence curve abruptly downward, approaching the narrow smooth linear border along a comparatively broad slope. The surface is marked by five to seven distinct annulations, which become obsolete near the maigin. In some specimens annulations one to three are unequally subdivided by a faint sulcus on the posterior slope of each, giving rise to a linear ridge which is obsolete distally. All the segments and even the linear ridges are covered with numerous tubercles.

Surface markings.--Unworn specimens show small tubercles on the glabella, free cheeks, palpebrum, palpebral lobes, thoracic axial segments, descending portion of the thoracic pleural segments, and on all the annulations of the pygidium.

Dimensions.-Specimen number 9116; length of cephalon 22 mm., length of thorax $44 \mathrm{~mm}$., length of pygidium $15 \mathrm{~mm}$. Greatest width across genal angles $36 \mathrm{~mm}$.

Position and localities.-Cedar Valley limestone or Upper Davenport formation, Iowa City, Solon, Brandon, Linn Junction, Elmira and Linwood. Professor Samuel Calvin also reports this species from Independence. A nearly complete specimen, No. 9289, from the Upper Davenport, Wapsipinicon shaly limestone, was collected by Dr. Thomas, at Linn Junction.

Remarks.-The cephalic characters of this species are so well defined and so adequately described by Hall (1888) that even the beginner will experience little difficulty in identifying Phacops 
rana. The pygidial characters, however, are subject to some variation and may cause mistakes unless a sufficiently large number is available showing both the young and adult characters. The outline of young specimens is transversely lentiform, the number of axial and pleural annulations is fewer, the axis is nearly parallel-sided, the tuberculation is more distinct and the first three pleural annulations are faintly subdivided. In more mature specimens the outline is semiovate and all the annulations are simple. The axis tapers much more rapidly and has a very characteristic acute termination which is not present in young specimens.

The description of Phacops rana is based on specimens numbered 9116-9121 inclusive.

\section{CIRRIPEDES OF THE DEVONIAN}

Superorder Cirripedia Burmeister

Order THORACICA Darwin

Family LEPIDOCOLEIDAE Clarke, J. M., 1896

Genus Lepidocolwus Faber 1887

Lepidocoleus iowensis Thomas

Bibliography of Lepidocoleus and some allied forms.

1888. Hall, J., and Clarke, J. M., Paleontology of New York, vol. VII, pp. 212-220. Strobilepis spinigera and five species of Turrilepas are described.

1896. Clarke, J. M., Notes on Certain Fossil Barnacles: Am. Geol. vol. XVII, pp. 137-143, pl. VII. The genera Turrilepas and Lepidocoleus are discussed, the generic characters of the latter are given and on the basis of multi- or biserial plates the family names Turrilepadidae and Lepidocoleidae.respectively are proposed.

1913. Savage, T. E., New Species of Arthropods: Am. Jour. Sci., vol. 35, pp. 149-152. Contains the original description and figures of Lepidocoleus illinoiensis. From the Clear Creek (Upper Oriskany) chert, Illinois.

1914. Moberg, Johann Christian, Silurian Cirripedes of Sweden; Lunds Universitets Arsskrift, N. F. Afd. 2, Bd. 11, Nr. 1, Kongl. Fysiografiska Sallskapets Handlingar, N. F. Bd. $26, \mathrm{Nr} .1$. 
1914. Bather, F. A., Paleozoic Cirripedes From Sweden; Geol. Mag., Decade 6, pp. 558-560. In this article Doctor Bather reviews the work of Moberg and indicates that there are about six species of Lepidocoleus described. Three are American and three European.

1915. Whithers, T. H., Some Paleozoic Fossils Referred to the Cirripedia: Geol. Mag., Decade 6, pp. 120-123 with figures. The opinion is expressed that Lepidocoleus, Plumulites, and Turrilepas are classified with the Cirripedia for want of a better place to put them.

\section{LePIDOColeus Iowensis Thomas}

Plate XXVII, figs. 15-16.

This very interesting species is represented in the University collection by thirteen more or less incomplete but otherwise well preserved specimens. The ensuing description is by Doctor. Thomas and the drawings are by $\mathrm{O}$. T. Walter.
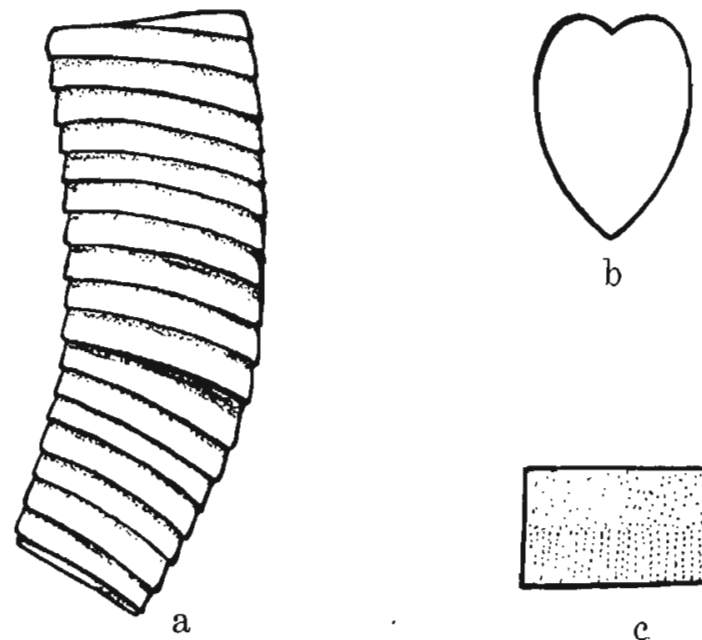

FIG. 27.-a, enlargement of Lepidocoleus iowensis, Mus. No. 9264; $b$, outline of cross section of sarne; c, part of one seg. ment to show the character and amount of imbrication.

The following characters are based on a study of the type specimen No.9264, as well as a number of others.

The body is elongate, gently arched dorso-ventrally; having a gentle curve along the dorsal edge and a more conspicuous curvature on the ventral edge toward the posterior end. The curvature 
on the ventral side is brought about in part by the decrease in size of the body posteriorly. The body is higher than wide, made up of two series of imbricating plates arranged bilaterally with respect to a longitudinal dorso-ventral plane and directly apposed along both the dorsal and ventral edges. From the ventral carinate edge each plate rises upward along a gently curved line to the top, bends inward in an abrupt and short curve and is then directed downward into a dorso-median groove to meet the plate of the opposite side. Passing posteriorly each plate overlaps about one-half of the next succeeding plate and is thicker in the exposed part than in the covered part. The exposed part of each plate is covered by numerous microscopic straight or slightly sinous lines and ridges which run parallel to the ventral edge. In cross section the anterior end is cordate, grading posteriorly into an elongate oral section.

Horizon and locality.-Devonian, Lime Creek shale, Devonocidaris zone, Floyd county, Towa. Collected by Dr. A. O. Thomas and Mr. C. H. Belanski.

Remarks.-This species is of special interest because it represents thus far the oldest phylogenetically and the last member chronologically of this genus. All the other Devonian species of Lepidocoleus have been recorded from lower horizons in both Europe and America.

\section{TRILOBITES OF THE MISSISSIPPIAN Order OPISTHOPARIA}

Family PROETIDAE

Genus Proetides gen. nov.

Characters of the genus.-Cephalon paraboloid in outline; free cheeks produced into spines at the genal angles. Glabella subconical, bearing three pairs of lateral furrows, which cross the median region in a progressively sharper curve from front to back; entire surface strongly tuberculate. Anterior border broad, deeply concave, having the outer margin strongly reflected. Eyes prominent. Pygidium semielliptical; axis conical, having eleven or more strongly tuberculate segments; pleural lobes moderately convex and with fewer annulations: 
This genus differs from all existing genera of Proetidae in that the three pairs of lateral furrows cross the median area. The short glabella and broad upturned border in front serve to distinguish it from Proetus, Phillipsia and Griffithides; the presence of facial sutures differentiates it from Brachymetopus; and the presence of more than one pair of glabellar lobes readily distinguishes it from Cyphaspis.

The six specimens (Nos. 2191, Univ. of Michigan) used by Winchell for the description of Phillipsia insignis are here made the basis for the new genus. The six specimens include two cranidia without free cheeks, one free cheek without a cranidium, and three pygidia. The association of these forms in the same formation is strongly suggestive, though not altogether conclusive, that they belong to one and the same species. In view of the association of the parts the cranidia are understood to constitute the genotype material.

\section{Proetides insiginis (Winchell) \\ Plate XXVI, figs. 13-17.}

1863. Phillipsia insignis Winchell, Proc. Acad. Nat. Sci. Philadelphia, vol. 15, p. 24.

The original description follows:

"Head paraboloid; border wide, broadly and deeply furrowed, with the margin reflected upward, and the lateral angles continued posteriorly in acuminate prolongations, reaching twice the length of the glabella from the anterior end; the margin and reflected portion of the test marked by fine longitudinal striae. Glabella elongate paraboloid, tuberculated. In the middle of the posterior border of the glabella is a pair of tubercles, and in front of these a second and third pair, the last resting on the middle of the glabella-the whole so arranged as to form two longitudinal rows; opposite the first pair are two small complementary lobes, with four pustules on the summit of each; opposite the second pair, on each side, a transversely elongate tubercle with a trifid crest; opposite the first pair, a similar tubercle with a bifid crest; the ornaments on the posterior half of the glabella being consequently arranged in three transverse series, in the posterior of which are ten elevations, in the middle eight, and in the anterior six; the anterior half of the glabella is covered by pustules somewhat promiscuously arranged, and varying in different speci- 
mens. Eyes large, globoid, slightly excavated by the palpebral lobe of the fixed cheek, situated opposite the posterior third of the glabella. Occipital ring broad, with its posterior margin elevated nearly as high as the posterior extremity of the glabella, and ornamented with a row of small, raised points turned backwards. Pygidium very convex, semielliptic, the axis very prominent and forming about one-third the width at the anterior margin; consisting of twelve to fourteen rings, each bearing six small tubercles, the whole of which are arranged in six longitudinal rows; the tubercles often worn down on the exterior of the test, but always well defined in the cast; lateral lobes bent rather abruptly downwards, having ten ribs, which become indistinct and disappear toward the margin, and are entirely wanting over the narrow space behind the axis; the anterior ribs showing a faint median groove toward their vanishing extremities, and a few of the posterior ones bearing feeble tuberculations toward their axial extremities.

The pygidium of this species nearly resembles that of $P$. truncatulus Phillips sp. (Geol. Yorkshire ii. p. 240, Pl. XII, fig. 13) but the head is widely different.

From the base of the Burlington limestone." More particularly from the Yellow sandstone which is the equivalent of Bed 4 of the Kinderhook according to Keyes.

The specimens upon which the above description is based are now at the University of Michigan. They were collected largely by Dr. C. A. White and submitted to Winchell for study.

Through the courtesy of Dr. G. M. Ehlers these specimens were loaned to the University for further study and comparison.

Profius cf. P. missouriensis Shumard

Plate XXVI, fig. 10.

1855. Proetus missouriensis Shumard, 1st and 2nd Geol. Rep. Missouri, p. 196, pl. B, figs. 13 a, b. Lithographic limestone, Hannibal, Louisiana and Chouteau Springs, Missouri.

1863. Phillipsia meramecensis ? Winchell, Proc. Acad. Nat. Sci. Philadelphia, pp. 24-25. Yellow sandstone, Burlington, Iowa.

The following is a very good description by $\mathrm{A}$. Winchell of a fragmentary cranidium from the Yellow sandstone lying beneath 
the "Burlington Limestone" at Burlington, which is the equivalent of Weller's bed No. $6^{10}$ of the Kinderhook at Burlington.

"Border of head of medium width, regularly convex, separated from the glabella by a narrow, distinct furrow. Glabella oblong, slightly quadrangular, a little broader behind than before, convex, highest in the middle; complementary lobes obliquely oval, protruding a little beyond the lateral boundaries of the glabella, from which they are separated by shallow depressions; a diminishing series of three feeble lobes in front of each complementary lobe; surface of the glabella smooth to the naked eye, but under a lens finely granulated. Eyes opposite the last quarter of the glabella.

The fragment above described is associated with the pygidium described by Dr. Shumard (Mo. Rep., Part ii, p. 199, Pl. B, fig. 9) simply in consequence of the granulated surface of the two, and the impossibility of proving them distinct. The original specimen, however, was obtained from the Archimedes limestone of St. Louis County, which, according to Prof. Hall, is the equivalent of the Keokuk Limestone."

Remarks.-The median length of this cranidium (Mus. Cat. No. 4908, Univ. of Michigan) from the anterior margin to the occipital groove is $7.4 \mathrm{~mm}$. The length of the glabella is $6.1 \mathrm{~mm}$. There exists a great deal of doubt concerning the specific reference of this cranidium. The only evidence upon which Winchell doubtfully based his identification is the granulated surface, which in itself is inadequate, and there is very little more conclusive evidence even now. The principal difference between our specimen and the type of $P$. missouriensis is one of size, the latter being a little more than twice as large as the former. Any other differences that may be present are only of minor importance. Dr. George H. Girty ${ }^{20}$ has a number of specimens from the Kinderhook beds at Burlington which he considers as belonging to the same species as the cranidium described by Winchell, but which Girty identifies as Proetus missouriensis. This identification by Girty is here used as additional evidence for referring the cranidium in question to Proetus missouriensis. 
Phillipsia tuberculata Meek and Worthen

Plate XXVI, fig. 22.

1870. Phillipsia tuberculata Meek and Worthen, Proc. Acad. Nat. Sci. Philadelphia, p. 52. Burlington limestone, Kinderhook, Pike County, Illinois.

1887. Phillipsia tuberculata Vogdes, Ann. New York Acad. Sci., vol. 4, p. 92. Burlington Group, Kinderhook, Pike County, Illinois.

1894. Phillipsia tuberculata Keyes, Missouri Geol. Survey, vol. 4, p. 235, pl. 32, fig. 6. Burlington limestone, Sedalia, Missouri.

To date only a single pygidium of this species has been reported from Iowa. This was collected by T. Van Hyning, and is said to have come from the Burlington limestone in the vicinity of Fort Madison. This specimen is now in the State Historical Department museum at Des Moines (Mus. No. 4474).

As intimated elsewhere in this paper Mr. Ben H. Wilson has been very helpful in securing specimens for comparison and study. It was he who located the above specimen in the Museum at I) $\in$ S Moines and he obtained the permission of Curator Harlan to have it loaned to the author for study and illustration. Except that it is somewhat smaller, all of its characters are identical with the original description of Meek and Worthen which is included verbatim.

"Attaining a large size. Head and thorax unlmown. Pygidium semielliptic, the length being nearly four-fifths the breadth, very convex; posterior margin obtusely rounded; lateral margins diverging rapidly forward, with convex outlines. Axial lobe well defined, obtuse, and rather prominent behind, and gradually widening forward, with nearly straight sides; rather distinctly more elevated than the lateral lobes, which it nearly equals in breadth at the anterior end, as seen in a direct view from above, but onefourth narrower than the latter, measuring over the curve of each; showing sixteen or seventeen straight, well defined segments, each of which is provided with six small tubercles, arranged so as to form six rows. Lateral lobes with about fourteen segments each, the very short posterior ones being nearly on a line with the axial lobe, while the others grow gradually more transverse anteriorly, so as to show only a moderate obliquity toward the front; all extending down so as to leave only a very 
narrow, undefined, smooth, marginal space, and each ornamented by from two or three to twelve tubercles, the number increasing regularly with the length of the segments toward the anterior. Surface between the segments and tubercles smooth.

Length of pygidium, 0.95 inch; breadth, 1.45 inches; convexity, 0.40 inch.

Locality and position.-Kinderhook, Pike County, Illinois. Burlington division of the Lower Carboniferous." To this add Burlington limestone, Fort Madison, Iowa.

\section{GRIFTITHIDES PORTLOCKI Meek and Worthen}

Plate XXVII, figs. 17-19.

1865. Phillipsia (Griffithides) portlockii Meek and Worthen, Proc. Acad. Nat. Sci. Philadelphia, p. 268.

1873. Phillipsia (Griffithides) portlockii Meek and Worthen, Geol. Surv. Mllinois, vol. 5, p. 525, pl. 19, figs. 6a, b, c.

1884. Griffithides portlocki Walcott, Pal. Eureka Dist., U. S. G. S., Nonograph , 8, p. 266, pl. 24, fig:s. 4, 4b.

1887. Griffithides portlocki Vogdes, Ann. New York Acad. Sci., vol. 4 , p. 93 , pl. 3 , fig. 9 .

1894. Phillipsia portlocki Keyes, Missouri Geol. Survey, vol. 4, p. 236 , pl. 32 , fig. 7 .

Description.-Cephalon subsemielliptical in outline, nearly twice as wide as it is long, produced into short pointed spines at the genal angles. Glabella large, ventricose, oval-elongate; surface curving abruptly downward in all directions from the greatest convexity in front of the eyes; anterior extremity rounded and forming the anterior margin of the cephalon; posterior extremity contracted to the occipital groove. A pair of short lateral furrows extends obliquely backward from the dorsal furrows opposite the anterior margin of the palpebral lobes. A second pair of stronger furrows originates at the dorsal furrows opposite the center of the palpebral lobes, curving obliquely backward to the occipital groove, dividing the posterior margin into three nearly equal parts and isolating, with the dorsal furrows, a pair of small, triangular, nodose basal lobes. Dorsal furrows deep and welldefined throughout. Occipital groove transverse, narrow and deep, somewhat wider as it continues along the posterior margin of the cheeks to the outer marginal groove at the genal angles. 
Occipital segment prominent, strongly arched transversely and. rising to about one-half the height of the glabella. Fixed cheeks narrow opposite the large median glabellar lobe, increasing in width posteriorly and continued laterally into the posterior limbs, which end approximately midway between the dorsal furrows and the genal angles. Palpebral lobes small, rising abruptly from the dorsal furrows to the level of the eyes, thence continuing a short distance laterally in a horizontal plane.

Eyes large, subglobular, rising strongly above the surface of the cheeks to about three-fourths the height of the glabella; situated a little more than one-half their length in front of the posterior margin of the cephalon and occupying the entire space between the palpebral lobes and the outer marginal groove.

The facial sutures originate on the posterior margin of the cephalon about midway between the dorsal furrows and the genal angles, extend obliquely forward and inward to the dorsal furrows back of the eyes. In front of the eyes they describe a gentle curve around the antero-lateral angles of the cranidium, cutting the anterior margin in line with the inner anterior margin of the eyes.

Free cheeks small, narrowly sulcate about the base of the eyes; anterior and posterior margins thickened and continued posteriorly into the genal spines, bounded proximally by a well-defined marginal groove which also continues into the genal spines.

Entire surface granulose, the granules at the base of the glabella being the largest.

Pygidium semielliptical in outline, approaching semicircular, broadly rounded posteriorly, wider than long, moderately convex; margin smooth and sharp-edged, narrow and decreasing in width anteriorly. The axis comprises about one-third the width of the pygidium, is well rounded transversely, slightly arched longitudinally and strongly elevated above the pleural lobes. Sides of the axis flattened appressed and sloping from a faint groove to the dorsal furrows. The tapering of the entire axis is more rapid than that of its median rounded part. There are fourteen well-defined segments separated from each other by narrow but deep groves which are shallower or nearly obsolete 
at the sides. The terminal axial segment is nodose and higher than those immediately in front of it. Situated along the crest of each segment there is a row of seven to eleven fine tubercles. The slope of each segment anterior to the crest is longer and more gentle than the posterior slope. Pleural lobes moderately convex, somewhat depressed along the axis, thence sloping strongly to the margin; marked by twelve ribs which extend nearly to the margin and are increasingly oblique toward the posterior end. The last two or three ribs are less distinct. No ribs present immediately back of the axis. The four anterior ribs are faintly but distinctly subdivided throughout four-fifths their entire length along the posterior margin. Each segment bears a row of fine tubercles similar to those on the axis. The areas between the rows of tubercles are smooth.

Dimensions.-Number 9242; median length of cranidium 10.3 mm., width across genal angles $17 \mathrm{~mm}$. This specimen is somewhat distorted. Number 9032, length of pygidium $14 \mathrm{~mm}$., width of same $17 \mathrm{~mm}$., length of axis $11.5 \mathrm{~mm}$., greatest width of axis $6.5 \mathrm{~mm}$.

Position and localities.-Keokuk limestone, Keokuk, Galland station and Montrose, Lee county (Wilson and Walter); Fort Madison (Superintendent Cruikshank, Mount Pleasant) ; section 4 , Jackson township, Henry county, along a small tributary of Skunk river.

Remarks.-Dismembered parts of this species occur rather commonly in the Keokuk limestone. It is the only trilobite found in this formation and is practically limited to bed number 6 of Savage's type section of the Keokuk in section 4, Jackson township, Henry county. Here also the specimens are more numerous than in any outerop in Lee county.

In the latter county the specimens have a smaller vertical range, occurring in thin layers of gray shaly limestone as in Henry county. Keyes, 1894, reported Griffithides portlocki for the first time from Iowa as a Phillipsia. His figure 7 , Plate 32 , is that of a nearly complete but somewhat distorted specimen. Subsequently it was reported by Savage, 1902, in the faunal list of the Keokuk limestone of Henry county, as a Phillipsia resembling 
Phillipsia portlocki. 'This species is a good index fossil of the Keokuk.

\section{GRIFFITHIDES WLSONI n, s.}

$$
\text { Plate XXVII, figs. 1-10. }
$$

1916. Phillipsia sp. Weller, Contributions Walker Museum, vol. 1, No. 10, p. 263, pl. 19, fig. 24. A pygidium is figured. 1918. Phillipsia (species undetermined) Thomas, Iowa Acad. Sci., vol. XXV, p. 615, pl. XII, fig. 25, pygidium.

Description.-The cephalic characters of this specimen are based on a nearly complete but greatly distorted head which is a part of an enrolled imperfect specimen, No. 9082, and a nearly perfect cranidium, No. 9100.

The cephalon is paraboloid in outline and apparently produced into spines at the genal angles. Each genal angle of specimen No. 9082 is broken. The outer margin slopes abrutly downward and is very narrow in front of the cranidium. The glabella is very prominent, oval oblong, rising considerably above the palpebral lobes and free cheeks. Sides subparallel, anterior margin and antero-lateral angles rounded. The surface is strongly convex transversely and moderately convex longitudinally. A shallow glabellar furrow originates opposite the center of each palpebral lobe and extends obliquely inward, thence abruptly backward, opening into the occipital groove, thus dividing the base of the glabella into three nearly equal parts and delimiting a pair of small subtriangular basal lobes. The dorsal furrow is very narrow and shallow. The occipital grooves rise abruptly from the dorsal furrows and continue nearly horizontally to the top of the eyes. The eyes are large, conspicuously raised above the surface of the free cheeks and appressed against the palpebral lobes in specimen No. 9082. The fixed cheeks are very narrow in front of the palpebral lobes but noticeably wider opposite the antero-lateral angles of the glabella. The free cheeks are large, depressed about the eyes, abruptly sloping at the margin and prolonged along the facial sutures in front of the cranidium. The outer margin of the cephalic shield is marked by delicate parallel im- 
pressed lines. The surface of the glabella is covered by numerous microscopic granules.

The thorax is too poorly preserved for accurate description: The right half is almost entirely wanting. The posterior two or three axial segments are strongly arched and well defined by intersegmental grooves. The dorsal furrows are broad and deep. Eight pleural segments are partly shown on the left side. The proximal two-thirds of each segment is subequally divided by a distinct shallow sulcus extending outward to the geniculation. The surface is finely granulose.

The pygidium is semi-elliptical in outline, somewhat wider than long, highly convex, marginal zone broad, smooth, of nearly uniform width throughout and bounded by a definite shallow submarginal furrow which is parallel to the free outer edge. The axis is prominent, strongly elevated, comprising approximately one-third the entire width of the pygidium anteriorly. It is strongly rounded transversely and moderately arched longitudinally. The sides are somewhat flattened near the dorsal furrow. The proportions of the axis diminish regularly from front to back. Segments fourteen in number, rounded and well defined anteriorly, fainter distally, separated by narrow but deep grooves which are continued almost to the dorsal furrows. The surface of each segment is marked by numerous minute granules. The pleural lobes rise strongly from the margin, thence arch over and flatten horizontally toward the dorsal furrows. Segments seven to eight, broad, rounded and well defined throughout, all ending at the submarginal furrow except the anterior two which extend beyond and approach the free outer edge. The surface is smooth to the unaided eye but under a lens a row of minute tubercles is seen on the posterior margin of each segment and similar tubercles are scattered over the remaining area.

Measurements.-Catalog No. 9082 ; median length of cephalon $8.2 \mathrm{~mm}$., width across genal angles $10.2 \mathrm{~mm}$. Length of pygidium $7.5 \mathrm{~mm}$., width of same $8.3 \mathrm{~mm}$., width of axis at anterior end 2.5 $\mathrm{mm}$.

Position and localities.-Number 9082, Pella beds, Ottumwa; from the limestone taken out of Des Moines river near the Mar- 
ket Street bridge (Mr. G. A. Larson). Number 9100, Pella beds, southeast quarter of section 17, township 71 north, range 6 east, Henry county, on the north side of Big.creek in the marl beds (Ben H. Wilson). Number 9024, five pygidia, Pella beds, three miles north of Fremont, Mahaska county (Ben H. Wilson). Number 9039, Pella beds, along north branch of Lizard creek, Webster county (Lees and Thomas). A pygidium of this species was collected by Dr. Max Littlefield in the Pella beds about one mile northwest of Ollie, Keokuk county.

Remarks.-This species is so different from any described species of Griffithides that a comparison is scarcely necessary. Griffithides mucronatus Girty, from the basal Fayetteville shale in the Fayettevilile quadrangle, Arkansas, agrees in a general way with our form but the average number of axial and pleural segments on the pygidium is somewhat larger and the surface marlsings of the glabella are coarser. The pygidium of $G$. wilsoni also bears a general resemblance to that of $G$. pustulosus Snider $^{21}$ from the Mayes limestone of the Chester group of northeastern Oklahoma in the character of the margin and the surface markings but it differs from the latter in being considerably smaller and in having fewer segments. The number of segments is given as thirteen to fourteen for the axis and ten to eleven for the pleural lobes but Snider's figure 14 of Plate 7 shows only nine segments for the axis and eight for the pleural lobes. The configuration of the glabella also is somewhat different, that of $G$. pustulosus being proportionally wider across the anterior end.

Weller's specimen of Phillipsia species from the Ste. Genevieve limestone of Monroe county, Illinois, is here included under $G$. wilsoni because the specimen shown in his figure 14, referred to above, is almost identical in appearance with the pygidia of $G$. wilsoni from Iowa.

Through the courtesy of Dr. George H. Girty, the writer was enabled to make direct comparisons with specimens taken from the Ste. Genevieve limestone, at Ste. Genevieve, Missouri. These are quite similar to the specimen figured by Weller and also to the Iowa material so that there can be little doubt that the ma-

21 Snider, L. C., Oklahoma Geological Survey, Bull. 24, pt. II, p. 120, pl. 7, figs. 14, 15, 16, July, 1915. 
terial from the Missouri and Illinois localities is conspecifie with that from Iowa. Included in the material loaned by Doctor Girty there is a very fine free cheek which is similar to that of the type specimen but has in addition a very long genal spine. The presence.of this spine is more conclusive circumstantial evidence that the broken genal angles of the Iowa type, No. 9082, represent the bases of lost genal spines.

A pygidium, No. 9039, now referred to this species, collected in the Pella beds at Fort Dodge, was briefly described by Professor Thomas as cited above. This is the first description of any of the material here referred to G. wilsoni. His diagnosis covers the essential points in so far as the meager material permitted.

Associated with the pygidia representing the above species are several, for example Nos. 9056 and 9083 from Iowa, which have a smooth margin, a nearly obsolete marginal groove and much less distinctly defined axial and pleural segments. The faint definition of segments is such a striking and easily observed character that the varietal name genevievensis is offered for these pygidia. These differences may be due to wear and abrasion, they may be due to the age of the specimens, they may be due to sexual characters of the species, or they may represent perfectly good varietal or specific features. If further material should prove the last assumption to be correct then the varietal name will probably receive specific rank.

The writer takes great pleasure in naming this species in honor of Mr. Ben H. Wilson, who collected most of the material for study.

\section{A DECAPOD FROM THE MISSISSIPPIAN}

Palaeopalaemon iowensis Walter

Plate XXVII, fig. 20.

1917. Palaeopalaemon iowensis Walter, Iowa Acad. Sci., vol. XXIV, p. 119, pl. Va. figs. 1-4.

The following is a copy of the original paper on this species:

"The specimen which is the subject of this paper is the same as the one noted by Professor Stuart Weller in his article on 'The Succession of Fossil Faunas in the Kinderhook Beds at Burling- 
ton, Iowa." The specimen was collected in an argillaceous shale -bed number 1 of the paper cited-and was among the material illustrating the fauna of that bed submitted to Doctor Weller by Professor Calvin and Professor Udden. In Weller's paper, page 69 , the specimen is referred with some doubt to Palaeopalaemon newberryi Whitfield, with a note that it 'is probably the same crustacean that Whitfield identified from Cascade,' now a part of the city of Burlington. Weller further comments that 'it is by no means certain that the Burlington specimens are identical with the types of the species or even that they belong to the same genus.' Whitfield had obtained his Burlington specimen from Dr. A. S. Tiffany of Davenport, Iowa. According to his description it differs in perfection from the one here discussed in having abdominal segments and telson both well preserved, while the cephalo-thorax is much less perfect. ${ }^{2}$ In spite of its imperfections Whitfield believed it to be identical with his type specimen $P$. newberryi described ${ }^{3}$ some years before from the Erie shale at Leroy, Ohio, and re-described by Hall and Clarke." The Erie shale is late Upper Devonian in age $e^{5}$ and is thus somewhat older than the bed in which the Burlington specimens occur.

The cephalo-thoracic portion only is preserved in the specimen at hand but this part exhibits features not heretofore noted in this class of remains. The dorsal and lateral regions of the cephalo-thorax are quite perfect and admit of a certain degree of accuracy in description but the appendages are either wholly wanting or are represented by the proximal segments alone.

The sides of the shrimplike cephalo-thorax are so strongly compressed that the postero-lateral portions of the branchiostegite are subparallel; the sides are longer below than above. The postero-ventral angle of the right branchiostegite is perfect, that of the left is partly broken. Transversely the dorsum is highly arcuate as far forward as the rostrum, which ends in a short spine; longitudinally the dorsum is very gently arched. The surface of the specimen is smooth, glossy, or polished in appearance and marked by greater and lesser punctæ. The greater punctæ are not very numerous and can be seen with the naked eye; the lesser punctæ are very numerous and can be seen only with the aid of a microscope. The region of the ophthalmic segment or the

1 Iowa Geological Survey, vol. X, pp. 68-79; 1900.

2 Amer. Geologist, vol. IX, p. 237 ; 1892.

3 Amer. Jour. Sci., 3d Ser., vol. XIX, pp. 40-42, pl. (circulated) figs. 1-8, 1880 ; also Ann. N. Y. Acad. Sei., vol. V, p. 505, pl. XII, figs. 19-21, Dec., 1890 ; and Geol. Ohio, vol. VII, p. 461, pl. VII, figs. $19-21 ; 1893$.

4 Pal. New York, vol. VII, p. 203, pl. XXX, figs. 20-23; 1888

5 Geol. Survey Ohio, 4th series, Bull. 15, p. $115 ; 1912$. 
rostral region is not arcuate but flattened and slopes gently to the dorso-lateral angle.

Fxtending from the posterior end of the cephalo-thorax to the transverse gastric sulcus there is a dorsal carina bearing a narrow mesial threadlike keel; anterior to the transverse gastric sulcus it is continued as a low lamellar crest and terminates in a short laterally compressed rostral spine. The hepatic sulcus (or sinus) begins at the base of the antenna, extends backwards along a slightly curved line for a distance of six millimeters, thence bends abruptly upward at a right angle to the dorsal carina, for a space of four millimeters whence it bends forward in a short curve, then back upon itself postero-dorsally at a sharp angle, and finally, after describing a short semicircle, it passes anteriorly along the side of the dorsal carina as the gastro-dorsal groove. There is but one spine on each side of the cephalo-thorax; each is located at the antero-lateral angle of the cephalic carapace and on a level with the base of the rostral spine. From this lateral spine a shallow but distinct groove extends backward to within a millimeter of the hepatic suleus and its course is almost parallel to the ventral margin of the cephalic carapace,- the two being approximately $1.5 \mathrm{~mm}$. apart. This groove bears a delicate threadlike ridge along its bottom. Beyond the hepatic sulcus and about $1 \mathrm{~mm}$. dorsally a similar groove continues nearly to the end of the cephalo-thorax, its course being practically parallel to the dorsal carina. This may be called the cardiaco-branchial groove. It is situated along a broad angle and with its elevated edges gives superficially the appearance of a ridge. Anteriorly the groove has a low but well marked rim or edge on either side and these rims are gradually more prominent and the groove less so until at the posterior end the two rims blend into a ridge or carina and the median groove is obsolete. Extending from a point slightly anterior to the midlength of the dorsum and at right angles to it is a short shallow transverse gastric sulcus; it reaches half way to the cardiaco-branchial groove or ridge and is deepest in the middle and decreases in depth toward both ends. Beginning at the anterior end of the cardiaco-branchial carina a broad rounded ridge extends postero-dorsally past the ventral end of the transverse gastric sulcus to a dorso-median point immediately posterior to the midlength of the cephalo-thorax. This ridge or carina the writer will call the "cervical ridge" as opposed to the common cervical groove of modern decapods. The portion of the cervical ridge between the transverse gastric sulcus and the dorsal end bears a fine mesial sinus. Running one millimeter dorsally and parallel to the anterior portion of the cervical 
ridge from the hepatic sulcus to the transverse gastric sulcus there is a deep gastro-hepatic sulcus. Two millimeters from the ventral margin of the cephalo-thorax and beginning at the postero-ventral apex of the hepatic sulcus there is a strong marginal carina which tends to coalesce with the free margin toward the posterior end. The entire tree margin of the cephalo-thorax is slightly thickened and the ventral part of it bears a small submarginal groove. The portion of the branchiostegite from the marginal carina downward is inwardly inclined.

'The eye stalks are partly preserved. The one on the right side has a height of $5 \mathrm{~mm}$.; the left, $1 \mathrm{~mm}$. A part of a laterally compressed peduncle of the right antennule is visible. The antennæ are not shown but the proximal portions of well developed antennal scales are present, forming a continuous shelf beneath the antennules. The line of demarcation has been obliterated but this condition may have been brought about by the process of substitution and by the great pressure exerted upon the thin inner margins of the scales, which may have been partly imbricated at the time of entombment. Each scale has a prominent outer submarginal groove which probably represents the main axis of support. 't'he dorsal surface of each scale bears a trace of a delicate diagonal pattern.

Extending forward from the antero-ventral side of the cephalic region are two long subcylindrical processes which are broken off anteriorly and somewhat swollen near their proximal ends. The part of the left member which is preserved has a length of 17 $\mathrm{mm}$. and its greatest diameter (dorso-ventral) is $5 \mathrm{~mm}$. Their surfaces are polished and punctate. Whether these appendages represent the first joints of the antennæ, segments of extremely large maxillipeds, or the first (or second) pair of proximal seg-. ments of the first pair of pereiopods the writer is unable to determine. From their comparatively large size it is probable that they are parts of the first pair of pereiopods. Compare, for example, the first pair of pereiopods of the modern form Sabinea princeps Smith. ${ }^{6}$ The remaining thoracic appendages are represented by their proximal segments only and these are preserved so poorly and in such a way that the number can not be determined with accuracy. One of them has a length of $4 \mathrm{~mm}$. and a diameter of $2 \mathrm{~mm}$; others are larger but' less well defined. On the ventral surface near the posterior end there is exposed a fragment which may be a part of an abdominal pleura or a part of the telson that may have become impressed on the under side

6 For figure see Bull. Mus. Comp. Zool., vol. XXIV, No. XVII, p. 38, Pl. VIII, fig. 1, Cambridge, 1893 . 
of the thorax while in a flexed position. The hardness of the matrix makes it difficult to learn its exact character.

Measurements.-Total length of the specimen $5 \mathrm{~cm}$.; dorsal length of the cephalo-thorax $32 \mathrm{~mm}$; greatest width $12 \mathrm{~mm}$.; height of carapace $13 \mathrm{~mm}$.; distance of antero-lateral spine from the rostral spine $7 \mathrm{~mm}$.; greatest distance across the base of antennal scales $8 \mathrm{~mm}$.

This specimen agrees with the genus Palaeopalaemon Whitfield, in that the cephalo-thorax is narrow and shrimplike as well as keeled on the back and sides but it differs from it in being rostrate. The appendages which Whitfield has called antennæ are here considered as parts of the first pair of pereiopods. The presence of a larger number of sulci and carinæ and of a right and left spine as well as the antennal scales further differentiate our specimen from $P$. newberryi. Indeed, the characters just pointed out are suggestive of the modern family Crangonidæ rather than of the family Palæmonidse. The first pair of legs strikingly suggest those of Sabinea princeps, mentioned above, while the large antennal scales are also characteristic of the Crangonidæ. However, in the absence of more complete material and, too, for the lack of a more appropriate genus for its.reception the writer prefers tentatively to refer the specimen to the old genus Palaeopalaemon. It is felt, moreover, that the characters pointed out are sufficiently different and important to deserve specific recognition and consequently the specific name iowensis is offered.

The specimen is in the paleontological collections of the State University of Iowa. It was preserved in an exceedingly hard nodule of pyritic shale, a part of which has been removed with sharp instruments and much patience. Museum number, 9277. -

\section{TRILOBITES OF THE PENNSYLVANIAN}

\section{Order OPISTHOPARIA}

\section{Family PRQETIDAE}

Griffithides scitulus Meek and Worthen

Plate XXVII, figs. 11-14.

1865. Phillipsia (Griffithides) scitula Meek and Worthen, Proc. Acad. Nat. Sci. Philadelphia, p. 270. Upper Coal Measures, Springfield, Illinois.

1872. Phillipsia scitula Meek, U. S. Geol. Surv. Nebraska; p. 238, pl. 6, fig. 9. Upper Coal Measures, Nebraska City, 
Nebraska; Springfield, Illinois. Lower Coal Measures, Illinois.

1873. Phillipsia (Griffithides) scitula Meek and Worthen, Geol. Surv. Tllinois, vol. 5, p. 612, pl. 32, fig. 3. Upper Coal Measures, Springfield, Illinois.

1884. Phillipsia (Griffithides.) scitula White, 13th Rep. Geol. Surv. Indiana, p. 173, pl. 39, figs. 6-9. Coal Measures, Perrysville, Eugene, Lodi, Silverwood and Newport, Indiana.

1887. Phillipsia scitula Herrick, Bull. Denison Univ., vol. 2, p. 62.

1887. Griffithides scitula Vogdes, Ann. New York Acad. Sci., vol. 4, p. 97, pl. 3, figs. 11-13. Upper Coal Measures; Springfield, Illinois; Plattsmouth, Nebraska. Lower Coal Measures, Illinois.

1923. Griffithides scitulus Thomas. Proc. Iowa Acad. Sci., vol. XXX, p. 478, pl. ii, fig. 38. (Appeared, July, 1924).

Description.-The cephalon of this species, number 9035, is represented by a fragmentary cranidium of a nearly complete but greatly distorted specimen. The cranidium is so poorly preserved that an accurate description is impossible. The glabella is pyriform, elongate, broadly rounded in front and bounded by a distinctly thickened anterior (marginal) rim or border which bears minute impressed lines parallel to the free margin. It is bounded on the sides and in front by a distinct dorsal furrow. The posterior half is strongly granular as seen under a lens, the anterior half less so. A pair of isolated, well-defined, triangular basal lobes is present. Between these, at the base of the glabella, there is a prominent median node. The occipital segment is broad, gently rounded, bearing a small median tubercle. Occipital furrow wide and moderately deep. Fixed cheeks narrow. Antero-lateral angles of cranidium rounded. The facial sutures cut the anterior margin in line with the palpebral lobes. Palpebral lobes small, crescentic and situated immediately anterior to the basal glabellar lobes. Length of cranidium $5.4 \mathrm{~mm}$.

Free cheek.-The only free cheek (number 9214) associated with the trilobite material is moderately large and continued at the genal angles into a prominent spine. The surface slopes gently away from a shallow suborbital groove to the thickened outer 
margin. The wide surface of this margin bears a number of parallel linear grooves which are continued into the genal spine. Maximum length of specimen is $8.2 \mathrm{~mm}$.

The thorax of specimen 9035 is incomplete, showing but seven segments. Trilobation distinct. Unlike the axial segments of the pygidium the axial segments of the thorax are evenly rounded, being neither flattened dorsally or flattened and appressed laterally. Each bears a row of small tubercles. The pleural lobes are flattened near the axis and bent strongly downward about midway, being, however, less geniculate than the pleural lobes of the pygidium. Each segment bears 2 to 3 minute tubercles.

Pygidium (number 9035) small, semielliptical, highly convex, width greater than length, bordered by a comparatively broad, steeply sloping margin which decreases but slightly in width anteriorly. Axis highly elevated, subquadrate in transverse crosssection, arched longitudinally; sides flat, steeply sloping, upper surface flattened to depressed and of nearly uniform width throughout. Entire axis tapers moderately from front to back and terminates abruptly at the submarginal furrow. Segments eleven, narrow, scarcely curving forward, divided by broad, deep grooves all of which are shallow on the sides and are progressively weaker posteriorly, where they are obsolete. Each segment hears four to six tubercles on the dorsum. The tubercles on the dorso-lateral angles are larger than those medially situated. Pleural lobes less convex than axis, bearing six segments and an indistinct seventh which extends back to the region of the eighth axial segment. These segments rise sharply from the submarginal furrow, thence bend over and approach the narrow and shallow dorsal furrow along a nearly horizontal upward slope. Fach bears a single large tubercle along the crest of the geniculation. Except for the tubercles already mentioned the entire surface is smooth.

Since the above was written a cranidium, No. 9291, and one pygidium, No. 9292, in excellent state of preservation, were collected in a black shaly limestone along Soldier creek, in section 9, Cooper township, Webster county, by Robert Rule and presented for examination and study by his teacher, Miss Katherine Mauthe 
of the Junior College faculty at Fort Dodge. The age of the beds along Soldier creek which furnished these specimens is Des Moines of the Pennsylvanian system. (See text figure 28.).

Dimensions.-Greatest length $6.8 \mathrm{~mm}$.; greatest width $8 . \mathrm{mm}$., length of axis $5.5 \mathrm{~mm}$; width of axis $3 \mathrm{~mm}$.

Horizon and locality.-Cherokee shaly limestone, Des Moines. Collectors; Mr. Ben H. Wilson, Prof. A. O. Thomas.

Remarks.-The Iowa material of this species is usually fragmentary, poorly preserved and rather uncommon. The generic

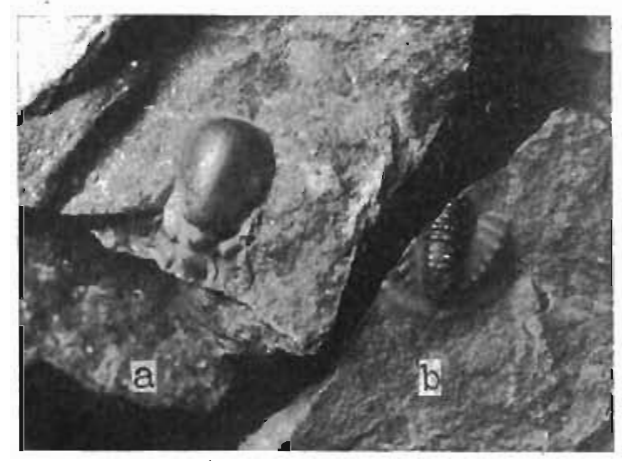

FIG. 28.-Griffithides scitulus. a, a well preserved complete pygidium $\times 2 / 1$. No. 9292 . complete pygidium $\times 2 / 1$. No. 9292. Dodge. Collected by Robert Rulo. and specific characters are fully established by the imperfectly preserved cranidium. The p y g i d i u m, however, shows only minor differences from Griffithides parvulus and Griffithides ornatus. It is the opinion of the writer, an opinion also shared by Dr. George H. Girty, ${ }^{21}$ that G. parvalus may prove to be a synonym of $G$. scitulus. The pygidium of $G$. orratus described by Girty from the Morrow formation differs in having a moderately broad, horizontally extended and slightly upturned marginal rim, which is entirely wanting in G. scitulus. But the original G. ornatus of Vogdes and that of Smith are essentially similar to our $G$. scitulus. The similarities of the cephalic shield are relied upon for the specific identification.

The name and synonymy of this species has long been $G$. scitula. However, the writer prefers to follow Grabau (Index Fossils, vol. II, page 305), Girty (Strat. Penn. Series Missouri, vol. XIII, pp. 300,306), and others in changing the spelling to scitulus to conform in gender with the generic name. 


\title{
Phillipsta major Shumard
}

\author{
Plate XXVI, figs. 27-28.
}

1823. Trilobus Say, Long's Exped. to Rocky Mts., vol. 1, p. 148, (224) footnote 176,17 . On west shore of Missouri river, five miles below Council Bluffs.

1858. Phillipsia major Shumard, Trans. St. Louis Acad. Sci., vol 1, p. 226. Upper Coal Measures, Clinton county, Missouri; valley of the Verdigris, and twelve miles south of Lecompton on the Santa Fe road, Kansas.

1861. Proetus longicaudus Hall, Des. New Species Foss., p. 80. Hamilton. (Found northeast of Des Moines, Iowa.)

1862. Proetus longicaudus Hall, 15th Rep. New York State Cab. Nat. Hist., p. 168, pl. 10, figs. 7-9.

1872. Phillipsia major Meek, U. S. Geol. Surv. Nebr., p. 238, pl. 3, figs. 2a-c. Upper Coal Measures, Bellevue and Plattsmouth, Nebraska; Clinton county, Missouri; Vermilion. river, twelve miles south of Lecompton, Kansas.

1876. Proetus longicaudus Hall, Illus. Dev. Foss. Crust., pl. 20, figs. 32-34.

1881. Proetus longicaudus Williams, Am. Journ. Sci., 3rd series, vol. 21, p. 156. Upper Carboniferous, Madison, Greenwood county, Kansas.

1887. Phillipsia major Herrick, Bull. Denison Univ., vol. 2, p. 60. Upper Coal Measures, Kansas.

1887. Phillipsia major Vogdes, Ann. New York Acad. Sci., vol. 4, p. 85, pl. 3, fig. 14. Upper Coal Measures, Clinton county, Missouri; valley of Verdigris river, twelve miles south of Lecompton on the Santa Fe road, Kansas ; Kansas City, Missouri; Bellevue, Nebraska.

1888. Proetus? longicaudus Hall, Pal. New York, vol. 7, p. 131, pl. 20, figs. 32-34. Near Madison, Kansas; northeast of Des Moines, Iowa.

1891. Phillipsia major Hare, Kansas City Scientist, vol. 8, p. 33, pl. 1, figs. 5, 8a-c. Coal Measures, Kansas City, Missouri.

1894. Phillipsia major Keyes, Missouri Geol. Survey, vol. 4, p. 238, pl. 32, figs. 8a-e. Upper Coal Measures, Kansas City, Missouri.

1897. Trilobus Harris, Bull. Am. Pal., vol. 1, p. 382 (112).

Description.-General form ovate-elongate, more broadly rounded in front than behind. Cephalon semicircular, strongly convex, genal angles produced into strong spines, width through the eyes greater than length along the midline; anterior margin 
evenly rounded, posterior margin within genal angles transverse. Glabella subquadrate, longer than wide, sharply set off from the fixed cheeks, rising strongly from front to back, greatest height opposite the anterior end of the posterior glabellar furrows; sides subparallel, expanding slightly opposite the palpebral lobes, which are near the posterior end; posterior margin of glabella curved forward medially. First and second glabellar furrows short, subparallel, directed inward and backward. First furrow shortest and on a level with or slightly back of the anterior margin of the eye. Posterior glabellar furrows curve back to the occipital segment, delimiting a subtriangular basal lobe at each postero-lateral angle. The distance between the first and second furrows is less than that between the second and third furrows. The margin in front of the glabella is narrow and thick. Palpebral lobes large, crescentic, and situated opposite the glabellar furrows, separated from the latter by a deep dorsal furrow. Occipital segment highly arched, increasing in width toward the center, separated from the glabella by a broad, moderately deep occipital groove.

Eyes very prominent, reniform, rising abruptly from a crescent-shaped ridge on the posterior half of the free cheeks. The eye has the appearance of a hand appressed against the cranidium between the palpebral lobes above and the free cheeks below. The facial sutures begin at the thickened posterior margin midway between the outer edge and the dorsal furrows; cutting diagonally across the thickened margin they are directed inward close to the dorsal furrows back of the eyes, thence forward around the palpebral lobes, spreading abruptly in front of the eyes and converging again to cut the anterior margin of the cephalon at an acute angle. Antennal pits present, one on each side of the glabella in the dorsal furrow in front of the eye.

The free cheeks are large, produced into strong spines posteriorly and short spinelike extensions anteriorly. The margin is thickened, rising abruptly at first, thence flattening out nearly horizontally and becoming somewhat depressed around the eyes. The posterior margin bears a strong furrow continuous with the occipital furrow. The fixed cheeks are narrow everywhere ex- 
cept opposite the antero-lateral portion of the glabella where they widen considerably.

Thorax̌ composed of nine segments. Axis rounded transversely and strongly elevated above the pleural lobes, segments narrow and rounded with broad intersegmental grooves. Pleural lobes less convex than the axis, divided into an outer free abruptly sloping portion and an inner nearly horizontal articulating. portion. Each segment is flattened and bears an elongate triangular lobe along the anterior margin in the region of the geniculation; this represents the fulcral process. The intersegmental grooves are narrow and shallow.

Pygidium convex, paraboloid, sides nearly straight, posterior margin narrowly rounded, length slightly greater than width, bordered by a smooth sloping margin which is very wide back of the axis and uniformly narrower toward the anterior end. Axis conical, upper part sharply rounded transversely, sides flattened and smooth, bearing a faint groove below the rounded portion. Width less than one-third the total width of the pygidium. The axis tapers uniformly, ending at the submarginal furrow. Segments eighteen to twenty, smooth and flattened. Intersegmental grooves narrow and shallow, obsolete on sides except near the anterior. end. The pleural lobes are strongly convex, rising abruptly from the smooth margin and depressed near the axis. Segments nine to twelve, broad, moderately oblique, decreasing abruptly in length posteriorly and ending opposite the posterior end of the axis. All the segments extend to the proximal part of the smooth marginal zone except the first two or three, which may extend beyond nearly to the edge. Entire surface smooth.

Dimensions of No. 9040.-Length of entire specimen $54 \mathrm{~mm}$., median length of cephalon $18.5 \mathrm{~mm}$., greatest width of same 30 $\mathrm{mm}$. Median length of pygidium $24 \mathrm{~mm}$., greatest width of same $26 \mathrm{~mm}$. Width of axis at anterior end $8.2 \mathrm{~mm}$.

Positions and localities.-Number 9040; Decatur county, collected by Prof. T. J. Fitzpatrick. Numbers 9025 to 9028, one cephalon and three pygidia, Missouri limestone, Winterset, collected by Prof. Samuel Calvin. Number 9030, a large pygidium from the Tarkio limestone, two and one-half miles northeast of 
Norwich, Page county, collected by Dr. Geo. L. Smith of Shenandoah.

This species is also reported by Dr. John L. Tilton from the Bethany Falls, Deer Creek, and Tarkio limestones of the Missouri series in southwestern Iowa and also from the Henrietta limestone, Des Moines series, north of Stuart.

Remarks.-The first record we have of this species dates back to the year 1823 as cited in the bibliography. Thomas Say found a cephalon and numerous pygidia in the sandstone five miles below Council Bluffs on the west bank of Missouri river. These he described in a footnote under the name "Trilobus." The description of the cephalon is as follows: "But a single specimen occurred, which we can, without any doubt, consider as the thorax of a trilobus; but whether or not it appertains to the same species with the above (pygidia), or to some other of which we have no other fragment, we are at a loss to determine. Like the above mentioned abdomen it is distinct from any we have figures of. It is of a narrow lunate form, highly convex, the disk destitute of sculpture, and the eyes prominent." From this description of the cephalon, the dimensions given of the pygidia and the locality it is reasonable to conclude that this could be none other than the subsequently described Phillipsia major. Not only is this the first record we have of a Phillipsia from the vicinity of Iowa but it is the first record of any trilobite whatsoever from this region.

The first entire specimen to be described and subsequently figured is that by Hall 1861 under the name Proetus longicaudus. This specimen was collected northeast of Des Moines and was referred to the Hamilton of the Devonian. In 1881 Williams recorded specimens, similar to those described by Hall ás Proetus longicaudus, from the Upper Carboniferous, near Madison, Greenwood county, Kansas. In the year 1888 Hall questions both the generic reference as well as the age of this species as illustrated by hï observations as follows :22

"There exists a great deal of doubt as to the generic status and the geological age of this species. The original and type specimen (Proetus longicaudus Hall) was presented many years ago by the Rev. Mr. Nash, of Des Moines, Iowa, together with specimens of Phacops rana, and was said to have been found in asso-

22 Hall, Pal. New York, vol. 7, 1888, p. 132. 
ciation with the latter at some point to the northeast of that place. This was the only specimen of the species known until certain others were described by Mr. H. S. Williams from a blue limestone near Madison, Greenwood County, Kansas, and he has suggested that these may have been derived from rocks not older than the Carboniferous. Mr. Williams' specimens were obtained from Mr. Edwin Walters of Hickman, formerly of Madison, Kansas, who, in response to inquiries, writes that he has found this species in association with Phacops bufo (rana). Admitting its association with this well known and characteristic fossil, its geological age would appear to be that of the Hamilton group.

On the other hand the species, in many important structural features, is more closely related to the Carboniferous Phillipsiae than to the typical forms of Proetus. The possession of but nine. thoracic segments, which appears to be a normal feature of the species at maturity, is known in but one other species of Proetus, viz., P. sculptus Barrande, from the étage G. For the genus Phillipsia this is the normal number. Moreover, the oval, slightly constricted glabella, the reniform eyes, the absence of occipital lobes, the great length of the pygidium and the number of its annulations are all Phillipsoid characters.

The species may ultimately prove to be a Carboniferous fossil, but any satisfactory determination of its age must await the acquisition of more complete material."

In view of the foregoing considerations of Hall and Williams and the identity of the descriptions and figures with Phillipsia major, Hall's Proetus longicaudus is here made a synonym.

The foregoing description of this species is based on characters observed in four separate pygidia, one nearly complete cephalon, one cranidium and a nearly perfect entire specimen.

\section{Bibliography}

The following citations are added to supplement the references listed under the synonymy of the species described in the paper. All these were actually consulted.

Barton,.Donald C., A new genus of the Cheiruridae with descriptions of some new species: Bull. Mus. Comp. Zoology, vol. LIV, no. 21, 1913.

Barris, W. H., New Fossils from the Corniferous Formation at Davenport: Davenport Acad. Sci., vol. II, pp. 282-288; 1876 1881. 
- Our Local Geology: Davenport Acad. Sci., vol. VII, pp. 14$32 ; 1889-1899$.

Bassler, Ray S., Bibliographic Index of American Ordovician and Silurian Fossils: U. S. Nat. Mus. Bull. no. 92, 1915.

- Stratigraphie Significance of Ostracoda: Bull. Geol. Soc. America, vol. 22, pp. 275-279.

Beecher, Charles E., Notes on Cambrian Fossils of St. Francis County, Missouri: Am. Jour. Sci., ser. 4, vol. XII, pp. 362$363 ; 1891$.

- On the thoracic legs of Triarthrus: Am. Jour. Sci., ser. 3, vol. 46, pp. 469-470; 1893.

- On the mode of occurrence and the structure and development of Triarthrus becki: Am. Geol., vol. XIII, pp. 38-43; 1894.

- Further observations on the ventral structure of Triarthrus: Am. Geol., vol. XV, pp. 91-100; 1895.

- The larval stages of Trilobites: Am. Geol., vol. XVI, pp. 166-197; 1895.

- Outlines of a natural classification of the Trilobites: Am. Jour. Sci., ser. 4, vol. III, no. 14, pp. 89-106, Feb., 1897. Also no. 15, pp. 181-207.

- Restoration of Stylonurus laconus, a giant Arthropod from the Upper Devonian of the United States: Am. Jour. Sci., ser. 4, vol. X, pp. $145-150 ; 1900$.

- Discovery of Eurypterid remains in the Cambrian of Missouri: Am. Jour. Sci., ser. 4, vol. XII, pp. 364-366; 1901.

- Ventral integuments of Trilobites: Am. Jour. Sci., ser. 4, vol. XIII, pp. 165-174; 1902. Also Geol. Mag., decade 4, vol. IX, pp. 152-163; 1902.

- Note on a Xiphosuran from the Upper Devonian of Pennsylvania: Am. Geol., vol. XXIX, pp. 143-146; 1902.

- Structure and development of Trilobites. Studies in Evolution: Geol. Mag., decade IV, vol. 9, pp. 151-163; 1902.

- On Paleozoic Phyllopocarida from Pennsylvania: Quart. Jour. Geol. Soc., vol. LVIII, pp. 441-449; 1902.

Bigney, Andrew J., A new bed of trilobites: Indiana Acad. Sci. Proc., pp. 139-191; 1910. 
Bernard, Henry M., Systematic position of the Trilobites: Geol. Mag., decade 5, vol. I, p. 230; 1894.

Burling, Lancaster D., The Albertella fauna in the Middle Cambrian of British Columbia and Alberta: Am. Jour. Sci., ser. 4, vol. XLII, pp. 469-472, December, 1916.

Calvin, Samuel, Description of Asaphus susae: Calvin in MS., Whitfield, Geol. Wisconsin, vol. IV, p. 236, pl. 5, fig. 3 ; and pl. 10, fig. 8.

- Description of Isotelus florencevillensis, n. sp.: Iowa Geol. Survey, vol. XIII, p. 46, 1902. Footnote.

Clarke, J. M., Notes on the genus Acidaspis: New York State Mus. Rept., vol. XLIV, pp. 91-104; 1892.

- Notes on some Crustacea from the Chemung Group of New York: 49th Ann. Rept. New York State Mus., vol. XI, pp. $729-738 ; 1895$.

- Relation of the Palaeozoic Arthropods to the Strand Line: Bull. Geol. Soc. America, vol. XXII, no. 2, pp. 279-280; 1911.

- A notable trilobite from the Percé rock: New York State Mus. Bull. 164, pp. 138-139, 1 pl., 1913.

- Type Specimens of Paleozoic Fossils in the New York State Museum: New York State Mus. Bull. no. 65, Paleontology 8, 1913.

- Possible derivation of the Lepadid Barnacles from the Phyllopods: Nat. Acad. Sci. Proc:, vol. IV, no. 12, pp. 384-386, Dec., 1918.

- and Ruedemann, Rudolf, Mode of Life of the Eurypterida: Science, new ser., vol. XXXII, p. 224, Aug. 12, 1910.

- and Ruedemann, Rudolf, The Eurypterida of New York: Memoir 14, New York State Mus., vol. I, Text, Vol. II, plates, 1912.

- and Swartz, Charles K., Systematic Paleontology of the Upper Devonian deposits of Maryland: Maryland Geol. Survey, Middle and Upper Devonian, pp. 539-699, 28 pls. (plates in separate volume), 1913.

Cleland, Herdman F., The fossils and stratigraphy of the Middle Devonic of Wisconsin: Wisconsin Geol. and Nat. Hist. Survey, Bull. no. 21 (Sci. no. 6), 222 pp., 57 pls., 5 figs., 1911. 
Dake, C. L., The Problem of the St. Peter Sandstone: School of Mines and Metallurgy, Univ. of Missouri, vol. 6, no. 1, 1921. Cumings, E. R., The Stratigraphy and Paleontology of the Cincinnati series of Indiana: 32d Ann. Rept. Geol. and Natural Resources of Indiana, pp. 1051-1064, pls. LIV, LV; 1908.

Eastman, Charles R., Text Book of Paleontology, adapted from the German of Karl A. von Zittel, 2d ed., vol. I, 1913.

Finch, Grant E., Notes on the position of the individuals in a group of Nileus vigilans found at Elgin, Iowa: Proc. Iowa Acad. Sci., vol. XI, pp. 179-181; 1904.

Foerste, Aug. F., The Generic Relations of the American Ordovician Lichadidae (with four plates): Am. Jour. Sci., vol. XLIX, Jan., 1920.

- A description of the Trilobites, Mollusks and Brachiopods of the Clinton Group of Ohio and Indiana: Geology of Ohio, vol. VII, 1893.

Girty, George H., Devonian and Carboniferous Fossils: U. S. Geol. Survey Monograph 32, part 2, pp. 476-581; 1899.

- Tabulated list of Invertebrate Fossils from the Carboniferous section of Kansas: U. S. Geol. Survey, Bull. 211, p. 83; 1903.

- Carboniferous of Colorado: U. S. Geol. Survey, Professional Paper no. 16, 1903.

- Notes on the Carboniferous Fossils, Geology and Ore deposits, Bisbee Quadrangle, Arizona: U. S. Geol. Survey, Professional Paper no. 21, pp. 46-53, 2 pls., 1904.

- The Guadalupian fauna: U. S. Geol. Survey, Prof. Paper 58, 1908.

- On some new genera and species of Pennsylvanian fossils from the Wewoka formation of Oklahoma: Ann. New York Acad. Sci., vol. XXI, pp. 119-156; 1911.

- New Genera and Species of Carboniferous Fossils from the Fayetteville Shales of Arkansas: Annals New York Acad. Sci., vol. XXI, pp. 189-238; 1910.

- Fauna of the Wewoka formation of Oklahoma: U. S. Geol. Survey, Bull. 544, 1915. 
- Fauna of the Batesville sandstone of Northern Arkansas: U. S. Geol. Survey, Bull. 593, 1915.

Grabau, A. W., Guide to the Geology and Paleontology of Niagara Falls and Vicinity: Bull. New York State Mus., no. 45, 1901.

- and Shimer, H. W., North American Index Fossils, vol. II, 1910.

Green, Jacob, Description of several new Trilobites: Amer. Jour. Sci., vol. XXXII, pp. 343-349; 1837.

Hall, James, Relations of the genus Eurypterus: Proc. Am. Acad. Arts and Sci., vol. IV, p. 353; 1860.

Herrick, C. L., Observations on the so-called Waverly Group of Ohio: Geol. Ohio, vol. VII, pp. 495-515, pls. 14-24, Chapter IV, 1893.

Jones, T. R., and Kirby, J. W., Notes on Paleozoic Bivalved Entomostraca, no. XXXII: Ann. Mag. Nat. Hist., ser. VI, vol. XVI, pp. $452-460 ; 1895$.

Keyes, Charles R., Missouri Geol. Survey, vol. IV, pt. 1, 1894; Paleontology, Missouri Crustaceans, Chapter X.

Kindle, E. M., and Breger, C. L., The Stratigraphy and Paleontology of the Niagara of Northern'Indiana: Geol. Survey, Indiana, 28th Ann. Rept., p. 397; 1903.

Kingsley, J. S., The Systematic Position of the Trilobites: Am. Geol., vol. XX, pp. 33-40: 1897.

Lake, Phillip, A Monograph on the British Cambrian Trilobites, part 1: Palaeontographical Society, London, pp. 1-28, plates 1-2, 1906. Part 2: (ditto), pp. 29-48, pls. 3-4, 1907. Part 3: (ditto), pp. 49-64, pls. 5-6, 1908. Part 4: (ditto) pp. 65-88, pls. 7-10, 1912.

McLearn, F. H., Revision of Some Phacopid Genera: Ottawa Naturalist, vol. XXXII, no. 2, pp. 31-36, May, 1918.

Mather, K. F., The Fauna of the Morrow Group of Arkansas and Oklahoma: Bull. Sci. Lab. Denison Univ., vol. XVIII, pp. 59-284, Dec., 1915.

Mickleborough, John, Locomotor Appendages of Trilobites: Geol. Mag., decade 3, vol. I, pp. 80-84; 1884.

Miller, S. A., North American Geology and Paleontology, 1889.

- and Gurley, W. F. E., New Species of Echinodermata and a 
new Crustacean from the Paleozoic Rocks: Illinois State Mus., Bull. Nat. Hist. no. 10, 1896.

Narraway, J. E., List of Trilobites found at Ottawa and Immediate Vicinity: Ottawa Naturalist, vol. XXVI, no. 8, pp. 98100, November, 1912.

Norton, Wm. H., Variations in the Position of the Nodes on the axial Segments of Pygidium of a Species of Encrinurus: Proc. Iowa Acad. Sci., vol. III, pp. 79-81; 1896.

Ohern, D. W., and Maynard, T. P., Systematic Paleontology of the Lower Devonian Deposits of Maryland: Maryland Geol. Survey, Lower Devonian, pp. 450-512; 1913.

Pilsbury, Henry A., Cirripedia from the Panama Canal Zone: U. S. Nat. Mus. Bull. 103, pp. 185-188, 1 pl., 1918.

Prosser, Charles S., and Kindle, E. M., Systematic Paleontology of the Middle Devonian Deposits of Maryland: Maryland Geol. Survey, Middle and Upper Devonian, pp. 124-335, 36 pls. (plates in separate volume), 1913.

Rathbun, Mary J., New Species of South Dakota Cretaceous Crabs: U. S. Nat. Mus. Proc., vol. LII, pp. 385-391, 2 plates, Feb. 23, 1917.

- Decapod Crustaceans from the Panama Region: U. S. Nat. Mus. Bull. 103, pp. 123-184, 13 plates, 1918.

- Raymond, Percy E., Notes on the Names Amphion, Harpina and Platymetopus. Am. Jour. Sci., vol. 29, pp. 377-378; 1902.

- The Trilobites of the Chazy dimestone: Ann. Carnegie Mus., vol. 3, pp. 328-386; 1905.

- On Two New Trilobites from the Chazy near Ottawa: The Ottawa Naturalist, vol. 24, Nov., 1910.

- Notes on Ordovician Trilobites, II. Asaphidae from the Beekmantown: Ann. Carnegie Mus., vol. 7, no. 1, pp. 36-44, pl. 14, 1910.

- Notes on Ordovician Trilobites, III. Asaphidae from the Lowville and Black River: Ann. Carnegie Mus., vol. 7, no. 1, pp. 46-59, pls. 15-16, 1910.

- Notes on Ordovician Trilobites, IV. New and Old Species from the Chazy: Ann. Carnegie Mus., vol. 7, pp. 60-79; 1910.

- Notes on the parallelism among the Asaphidae: Trans. 
Royal Soc. Canada, ser. 3, vol. 5, sec. IV, pp. 111-120; 1912.

- Some changes in the names of genera of Trilobites: The Ottawa Naturalist, vol. 26, Feb., 1913.

- A further note on Cryptolithus versus Trinucleus: Ottawa Naturalist, vol. 27, pp. 26-30, May, 1913.

- Description of some New Asaphidae: Canada Geol. Survey, Victoria Memorial Mus. Bull. no. 1, pp. 41-48, October, 1913.

- A revision of the Species which have been referred to the Genus Bathyurus: Canada Geol. Survey, Victoria Memorial Mus. Bull., no. 1, pp. 51.-69, October 23, 1913.

- Notes on the Ontogeny of Isotelus gigas DeKay: Bull. Mus. Comp. Zool. Harvard Coll., vol. 58, no. 5, pp. 247-263; 1914.

- Notes on the Ontogeny of Paradoxides, with Description of a New Species. Bull. Mus. Comp. Zool. Harvard College, vol. 58 , no. 4, pp. 225-244; 1914.

- New and Old Silurian Trilobites from Southeastern Wisconsin with Notes on the Genera of Illaenidae: Bull. Mus. Comp. Zool. Harvard College, vol. 60, no. 1, pp. 3-41; 1916.

- The genera of Odontopleuridae: Ottawa Naturalist, vol. 29, no. 11, pp. 135-139, Feb., 1916.

- A new Ceraurus from the Chazy: New York State Mus., Bull. no. 189, pp. 121-126, 1 pl., Sept. 1, 1916.

- Beecher's Classification of Trilobites after Twenty Years: Am. Jour. Sci., vol. XLIII, March, 1917.

- Some New Ordovician Trilobites: Bull. Mus. Comp. Zool., vol. LXIV, no. 2, pp. 271-296, July, 1920.

- The Appendages, Anatomy and Relationships of Trilobites: Memoirs of the Connecticut Acad. Arts and Sci., vol. VII, December, 1920.

- American Species of Ceraurus: Bull. Mus. Comp. Zool., vol. 54 , no. 20, pp. 523-543, with two plates, Nov., 1913.

- and Barton, Donald C., A Revision of American Species of Ceraurus: Bull. Mus. Comp. Zool., vol 54, no. 20, 1913.

- and Narraway, J. E., A new American Cybele: Ann. of the Carnegie Mus., vol. 3, no. 4, pp. 597-602; 1906.

Reed, F. R. C., The evolution of Cheirurus: Geol. Mag., London, decade IV, vol. 3, pp. 117-123 and pp. 161-167; 1896. 
- Notes on the Genus Lichas: Quart. Jour. Geol. Soc. London, vol. 58, p. 50; 1902.

- The Classification of the genera of Phacopidae. Geol. Mag., London, decade V, vol. 2, pp. 171-178, 224-228; 1905.

Rowley, R. R., The Geology of Pike County, Missouri: Missouri Bur. Geol. and Mines, 2d ser., vol. 8, 1908.

Ruedemann, Rudolf, Account of Some New or Little Known Species of Fossils, mostly from Paleozoic Rocks of New York: Articles II, IV, V, VI of Bull. New York State Mus. No. 189, 1916.

- The Paleontology of Arrested Evolution: New York State Mus., Bull. no. 196, pp. 107-134, A pril 1, 1917.

Savage, T. E., Stratigraphy and Paleontology of the Alexandrian series in Missouri and Illinois, part 1: State Geol. Survey Illinois, Bull. no. 23, 1913.

- Some Interesting New Species of Arthropods from the Devonian Strata of Illinois: Am. Jour. Sci., vol. 35, pp. 149$152 ; 1913$.

Schmidt, Friederich, The Eurypterid beds of Oesel as Compared with Those of North America: Bull. Geol. Soc. America, vol. 3, pp. 59-60; 1892.

Shumard, B. F., Notice of some New and Imperfectly Known Fossils from the Primordial Zone of Wisconsin and Missouri: Trans. Acad. Sci. St. Louis, vol. 2, pp. 101-113, 186168.

Slocom, Arthur Ware, New Trilobites from the Maquoketa beds of Fayette County, Iowa: Field Mus. Nat. Hist., Pub. 171, Geol. ser., vol. 4, no. 3, pp. 43-83, Oct., 1913. Also Iowa Geol. Survey, vol. XXV, pp. 183-249; 1916.

Snider, L. C., Oklahoma Geological Survey, Bull. 24, pt. III, p. 120, pl. VII, 1915.

Ulrich, Edward O., and Bassler, Ray S., New American Paleozoic Ostracoda. Notes and descriptions of Upper Carboniferous genera and species: Proc. Nat. Mus., vol. 30, pp. 149-164, pl. 40, 1906.

- New American Paleozoic Ostracoda. Preliminary Revision of the Beyrichiidae with Descriptions of new Genera. Proc. U. S. Nat. Mus., vol. 35, pp. 277-340, pls. 37-40, 1909. 
Vogdes, A. W., Notes on Paleozoic Crustacea, No. 5. Carboniferous Trilobites from Missouri: Proc. California Acad. Sci., 2 d ser., vol. 6, p. $197 ; 1896$.

- The Genera and Species of North American Carboniferous Trilobites: Ann. New York Acad. Sci., vol. 4, 1887.

- A Bibliography of Paleozoic Crustacea from 1698 to 1889, including a list of North American Species and a Systematic Arrangement of the Genera: U. S. Geol. Survey Bull. 63, 1890.

-The genus Encrinurus: its Fistory, its Species, its Proper Division in the Family of Trilobites: Trans. San Diego Soc. Nat. Hist., vol. 1, no. 2, pp. 61-82; 1907.

- Paleozoic Crustacea. The Publications and Notes on the Genera and Species during the Past Twenty Years, 18951917: Trans. San Diego Soc. Nat. Hist., vol. VIII, no. 1, 1917.

Walcott, Charles D., The Trilobite: New and Old Evidence Relating to Its Organization: Bull. Mus. Comp. Zool., vol. 8, no. 10, March, 1881.

- Paleontology of the Eureka District: U. S. Geol. Survey Monograph no. 8, 1884.

- Fauna of the Lower Cambrian or Olenellus zone: 10th Ann. Rept. U. S. Geol. Survey, 1890.

- Cambrian Faunas of China: Proc. U. S. Natl. Mus., vol. 29, pp. 1-106; 1905.

- - Cambrian Faunas of China: Proc. U. S. Natl. Mus., vol. 30, pp. 563-595; 1906.

- Cambrian Geology and Paleontology, No. 2. Cambrian Trilobites: Smithsonian Misc. Coll., no. 1805, vol. 53, 1908.

- Cambrian Geology and Paleontology, No. 5. Smithsonian Misc. Coll., vol. 53, Dec. 10, 1908.

- Middle Cambrian Merostomata: Smithsonian Misc. Coll., vol. 57, no. 2, 1911.

- Cambrian Geology and Paleontology, No. 6. Olenellus and other genera of the Mesonacidae: Smithsonian Misc. Coll., vol. 53 , no. 6 , pp. 231-422; 1910.

- Cambrian Geology and Paleontolögy, 2, No. 6. Smithsonian Misc. Coll., vol. 57, no. 6, 1912. 
- Cambrian Geology and Paleontology, 2, No. 9. New York Potsdam, Hoyt F'auna: Smithsonian Misc. Coll., vol. 57, no. 9, 1912.

- The Cambrian Faunas of China: Carnegie Inst., vol. 3, Aug. 1, 1913.

- Cambrian Geology and Paleontology, 2, No. 13. Dikelocephalus and other genera of the Dikelocephalinae. Smithsonian Misc. Coll., vol. 57, no. 13, 1914.

- Cambrian Geology and Paleontology, No. 3. Cambrian Trilobites: Smithsonian Misc. Coll., vol. 64, no. 3, 1916.

- Cambrian Geology and Paleontology, 3, No. 5. Cambrian Trilobites: Smithsonian Misc. Collections, vol. 64, no. 4, pp. 303-456; 1916.

- Cambrian Geology and Paleontology, No.4. Appendages of Trilobites: Smithsonian Misc. Coll., vol. 67, no. 4, pp. 115216, 29 plates, 3 figs., Dec., 1918.

Walter, Otto T., Notes on a Decapod Crustacean from the Kinderhook Shale at Burlington: Proc. Iowa Acad. Sci., vol. XXIV, pp. 119-123, plate Va, 1917.

Weller, Stuart, Bibliographic Index of North American Carboniferous Invertebrates: U. S. Geol. Survey Bull. 153, 1898.

- Report on the Paleontology of New Jersey: Geol. Surv. New Jersey, vol. 2, Trenton, 1903.

- The Paleontology of the Niagara Limestone in the Chicago Area. The Trilobita: Bull. Chicago Acad. Sci., no. IV, part $2,1907$.

- Kinderhook faunal studies. III, The Fauna of Beds No. 3 and No. 7, Burlington, Towa: Trans. St. Louis Acad. Sci., vol. 1, pp. 147-214, 9 pls., 1901.

- Kinderhook faunal studies. The fauna of the Fern Glen Formation: Bull. Geol. Soc. America, vol. 20, pp. 265-332, pls. 10-15, 1909.

Wetherby, A. G., Description of New Fossils from the Lower Silurian and the Subcarboniferous Rocks of Ohio and Kentucky: Jour. Cincinnati Soc. Nat. Hist., April, 1881.

White, C. A., and Whitfield, R. P., Observations on the Rocks of the Mississippi Valley which have been Referred to the Chemung Group of New York, Together with Descriptions 
of new Fossils from the same Horizon at Burlington, Iowa: Proc. Boston Soc. Nat. Hist., vol. 8, pp. 289-306.

Whiteaves, J. F., The fossils of the Devonian Rocks of the Islands, Shores, or Immediate Vicinity of Lakes Manitoba and Winnipegosis: Contributions to Canadian Paleontology, vol. 1, pt. IV, 1892.

Whitfield, R. P., Contributions to the Paleontology of Ohio: Geol. Survey Ohio, vol. 7, pp. 407-494, pls. 1-13, 1893.

- List of Fossils, Types and Figured Specimens used in the Paleontological Work of R. P. Whitfield, showing where they are probably to be found at the present time: Ann. New York Acad. Sci., vol. XII, pp. 139-186; 1900.

- assisted by Hovey, E. O., Catalogue of the type and figured specimens in the Paleontological Collections of the Geological Department, American Museum of Natural History: Bull. Am. Mus. Nat. Hist. vol. XI, pp. i-vii, 1-71; 1898 . Also pp. 74-188; 1899. Also vol. XI, pt. iii, pp. 190-356; 1900.

Williams, H. S., Correlation of Geological Faunas: U. S. Geol. Survey Bull. 210, 1903, Ser. C, Systematic Geology and Paleontology, 61.

Woodward, H., A Monograph of the British Carboniferous Trilobites: Palaeontographical Society, part 1, 1889. 


\section{PLATES ILLUSTRATING IOWA TRILOBITES}

All the figures represented by these plates are of natural size unless otherwise indicated. 


\section{PLATE X:}

Figs. 1-9. Dikelocephalus minnesotensis Owen.

1. A cranidium showing four glabellar furrows, the first and second pair being rather indistinct. This figure also shows a nearly complete thoracic segment. No. 9017.

2. The outline of a complete free cheek and a part of the anterior border of the cranidium. The outline is marked with ink. No. 9010.

3. A hypostoma, No. 9014; and 4, a smaller hypostoma, No. 9015.

5. An incomplete thoracic segment showing the diagonal pleural groove.

6. A ventral impression of a free cheek. No. 9018.

7. A pygidium of average size. No. 9013.

8. A very well preserved cranidium showing the normal convexity of the glabella and of the anterior border. This specimen was collected by Dr. M. M. Leighton at Baraboo, Wisconsin. No. 9005.

9. Longitudinal median profile of figure 8, showing the curvature of the glabella and the anterior border.

Agnostus parilis Hal

Fig. 10. A cephalon, No. 9240. Times 4.

Fig. 11. A pygidium, No. 9239. Times 4 .

Saukia pyrene Walcott.

Fig. 12. A small incomplete cranidium. No. 9004.

Fig. 13. An enlargement of the same. 

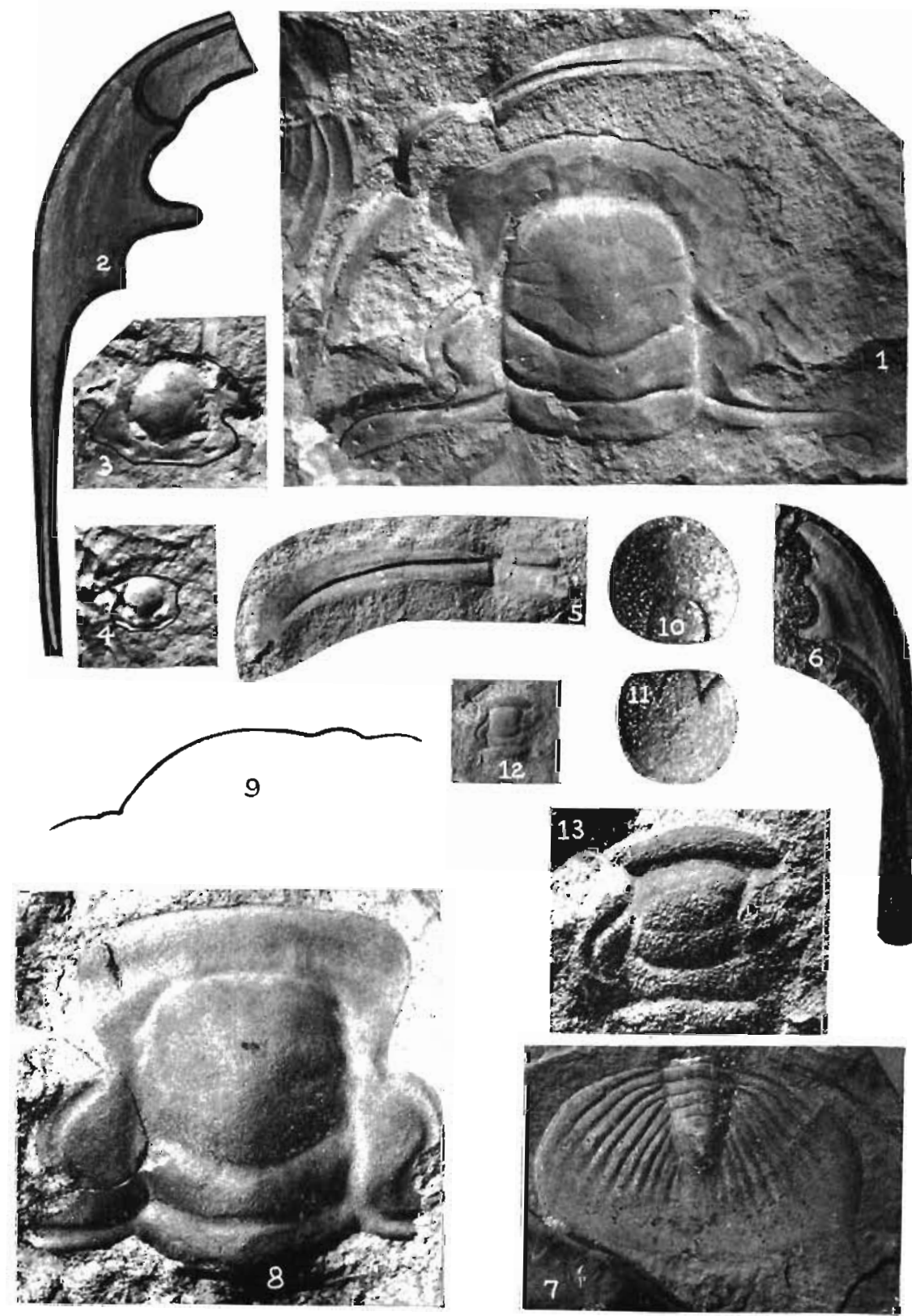


\section{PLATE XI.}

Figs. 1-4. Aglaspis thomasi Walter.

1. The holotype cranidium. No. 9009.

2. The same greatly enlarged.

3. A part of an abdominal segment showing the pitted surface. No. 9020.

4. The same specinen considerably enlarged.

Figs. 5,6. Conaspis micros Walter. 185

Fig. 5. Dorsal aspect of the type cranidium. No. 9239, times 2 .

Fig. 6. The same specimen, times 7 .

Figs. 7-10. Saratogia wisconsensis (Owen) 186

7. A large cranidium from which the occipital spine has been broken away. The base of the spine is shown. No. 9238c.

8. A firee cheek showing the long genal spine. No. 9238d.

9. A smaller cranidiun. No. 9238a.

10. A pygidium referred to the same species. No. 9238b.

Figs. 11-14. Ptychaspis striata Whitfield

11. A slab showing a cranidium, just above the center of the photograph, in association with fragments of Saratogia wisconsensis. No. 9234.

12. An incomplete free cheek, a part of the spine being lost. No. 9236.

13. A pygidium showing the longitudinal subdivisions of the pleural segments. No. 9279.

14. A larger pygidium showing similar characters. No. 9235 .

Figs. 15-20 Illaenwrus calvini Walter.

15. A cranidium outlined in ink. No. 9282.

16. Parts of a dismembered specimen showing a cranidium associated with several thoracic segments and a pygidium similarly associated. To the left of the cranidium there is a free cheek. No. 9001.

17. View of a nearly complete specimen showing the location of the thorax and the pygidium. No. 9000.

18. Dorsal aspect of a pygidium showing indistinct lobation. No. 9280 .

19. A free cheek. No.9003.

20. A pygidim and free cheek. No. 9281. 

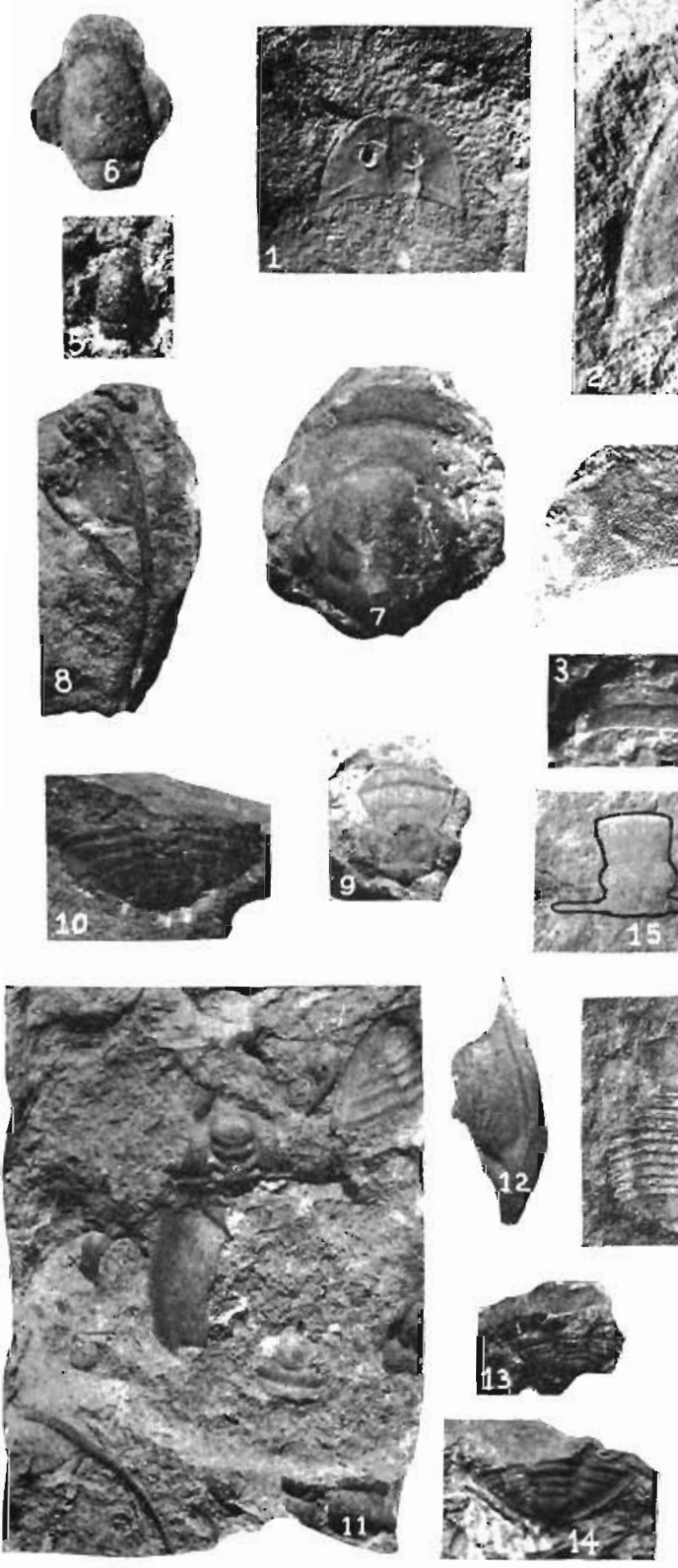
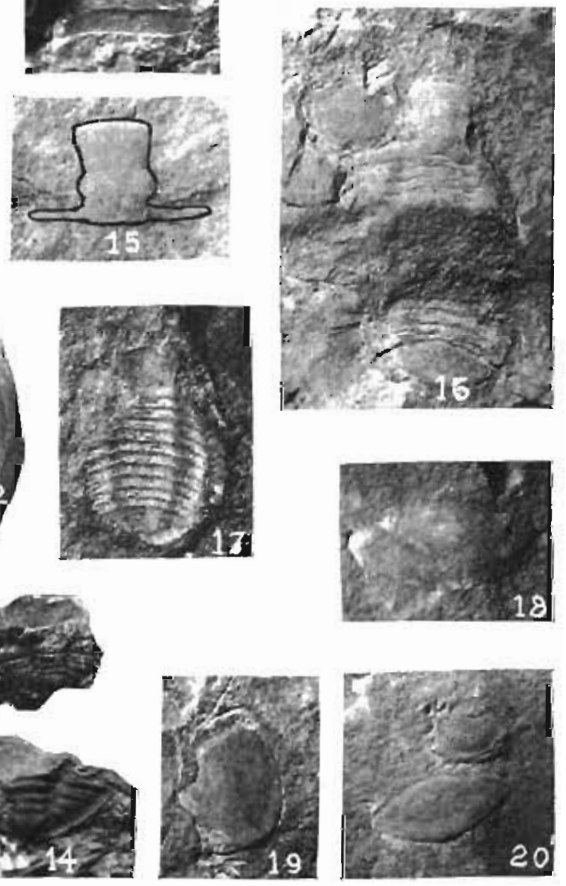


\section{PLATE XII.}

This is a view of a slab enlarged two diameters to show the crowded association of trilobite remains as it occurs in the Eau Claire formation. No. 9239.

Fig. 1. Parts of Agnostus parilis. See also Plate X.

Fig. 2. Cranidia of Concapis micros. See also Plate XI.

Fig. 3. l'ygidium of Ptychaspis striata. See also Plate XI.

Fig. 4. Cranidiun of Ptychaspis striata. 


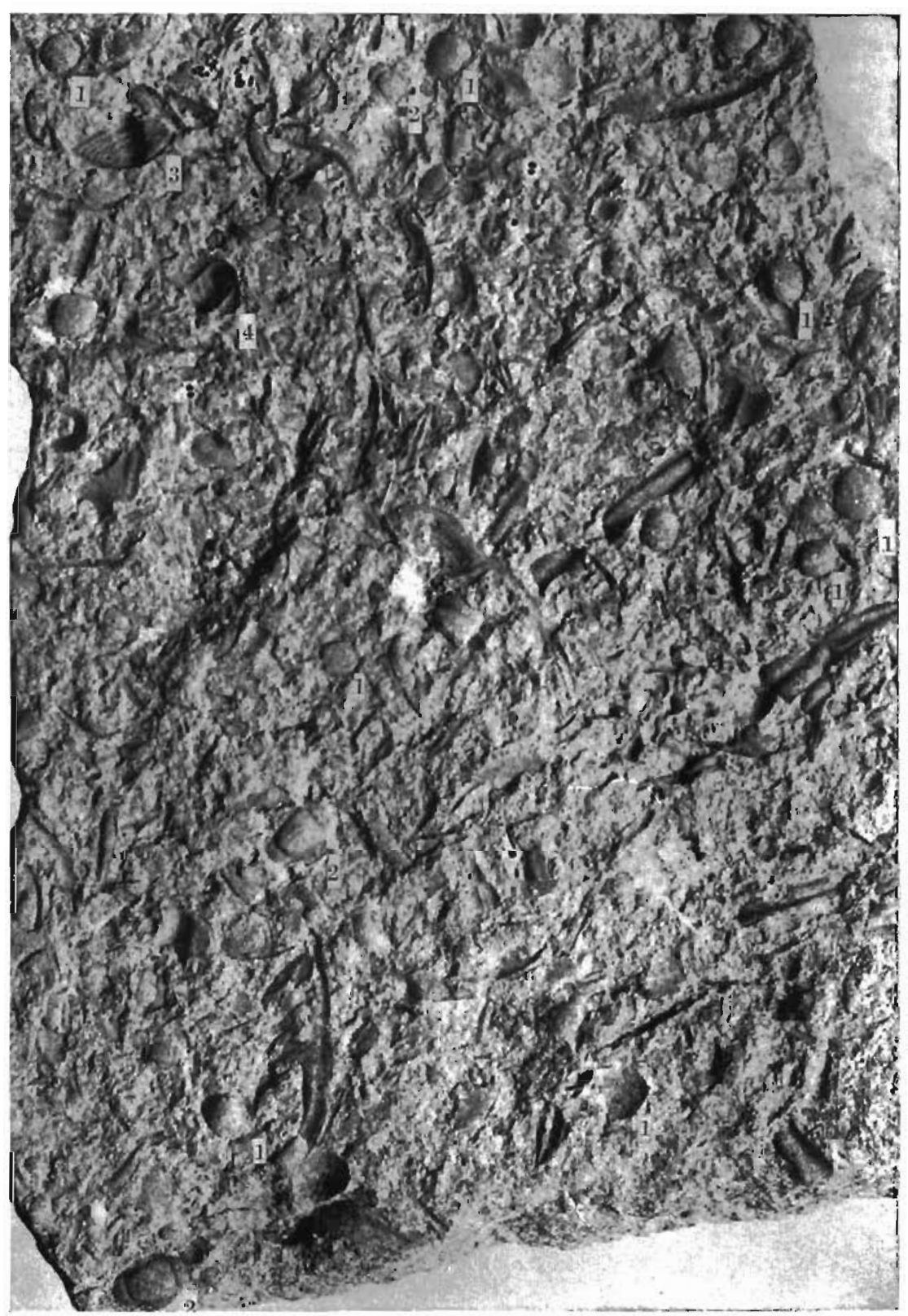




\section{PLATE XIII.}

Eoharpes cf. E. ottawaensis (Billings) 199

Fig. 1. The under side of the brim of the cephalic shield showing the pitted surface. No. 9205. This specimen was found by Mr. A. G. Becker near McGregor.

Fig. 2. Similar view of a smaller specimen, No. 9192, collected by the witer at Dubuque.

Homotelus florencevillensis (Calvin) 210

Fig. 3. A very young specimen showing a small tubercle on the occipital segment and very small spines on the genal angles. No. 9134.

Fig. 4. An enlarged view of the same specimen.

Fig. 5. A large specimen upon which Calvin originally erected this species. No. 9161.

$$
\text { Bathyurus spiniger (Hall) }
$$

Fig. 6. An incomplete cephalon showing the tuberculate surface and traces of the lateral glabellar furrows. No. 9188 .

Fig. 7. A hypostoma of a Bathyurus which, because of its association with the cephalon of fig. 6 , is tentatively referred to this species. No. 9186.

Ectenaspis beckeri (Slocom)

Fig. 8. Profile view of the type specimen to show the curvature of the anterior prolongation of the head. Note the Panderian organs.

Fig. 9. Dorsal view of the same specimen, which was loaned to the University for study by the collector, Mr. A. G. Becker. 

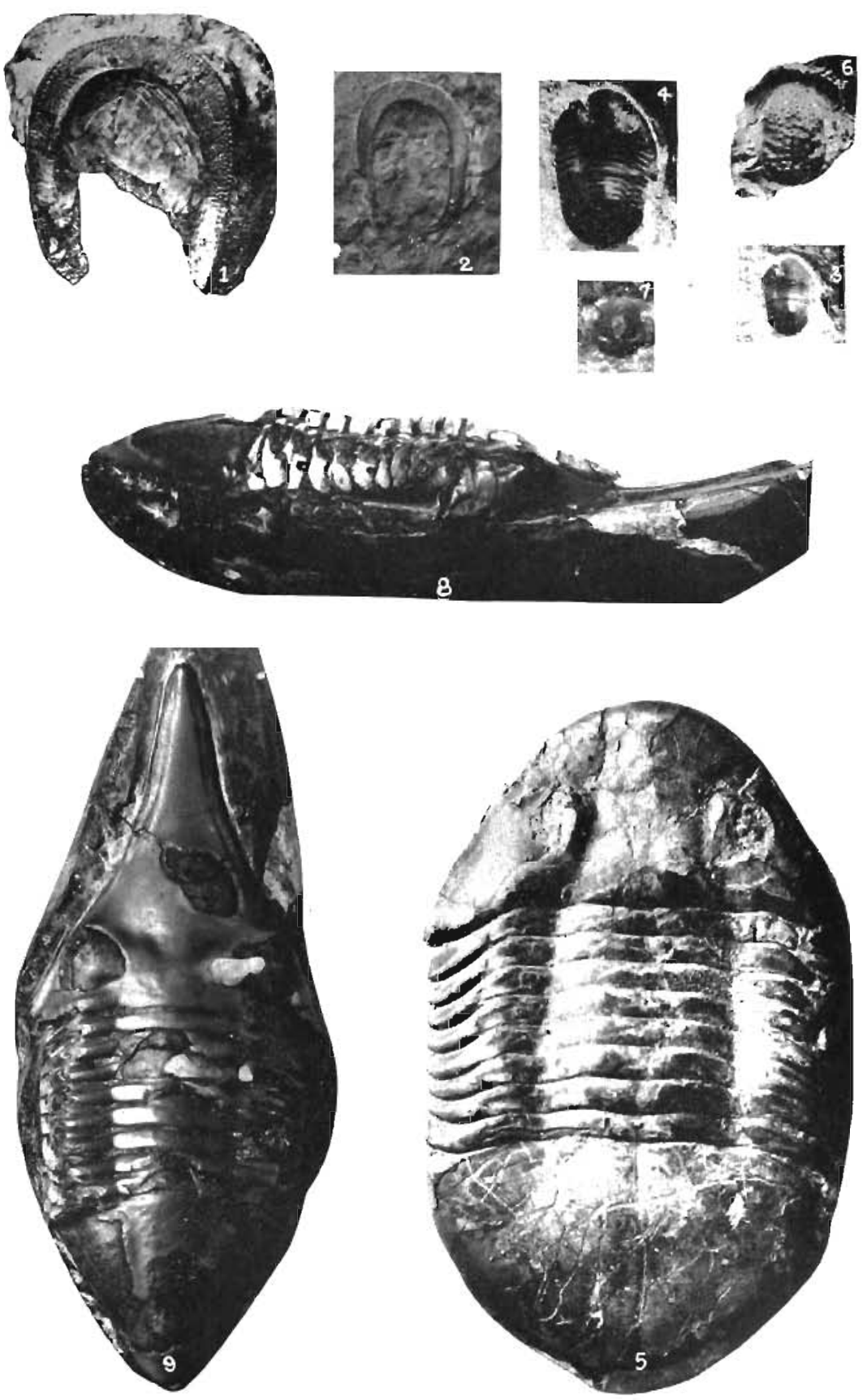


\section{PLATE XIV.}

Figs: 1-8. Brachyaspis alacer (Billings) 208

Figures 1, 2 and 3 represent different views of this species as delineated by Professor Calvin on the basis of the specimen represented by figures 4,5 and 6 . These drawings were made approximately thirty to thirty-five years ago.

4. A dorsal view which does not show the deflected portion of the head. No. 9166 .

5. Front aspect of the same specimen. Facial sutures well shown.

6. Lateral view of the same specimen.

7. Cephalic view of an enrolled specimen. No. 9168.

8. Pygidial view of the same specimen.

Figs. 9, 10. Brachyaspis species

Fig. 9. This represents a large cheek thought by Dr. Percy E. Raymond to be that of a large Brachyaspis. No. 9175.

Fig. 10. A view of a large pygidium having a narrow axial lobe. This also is tentatively referred to a large Brachyaspis by Dr. Raymond and the writer. No. 9174. 

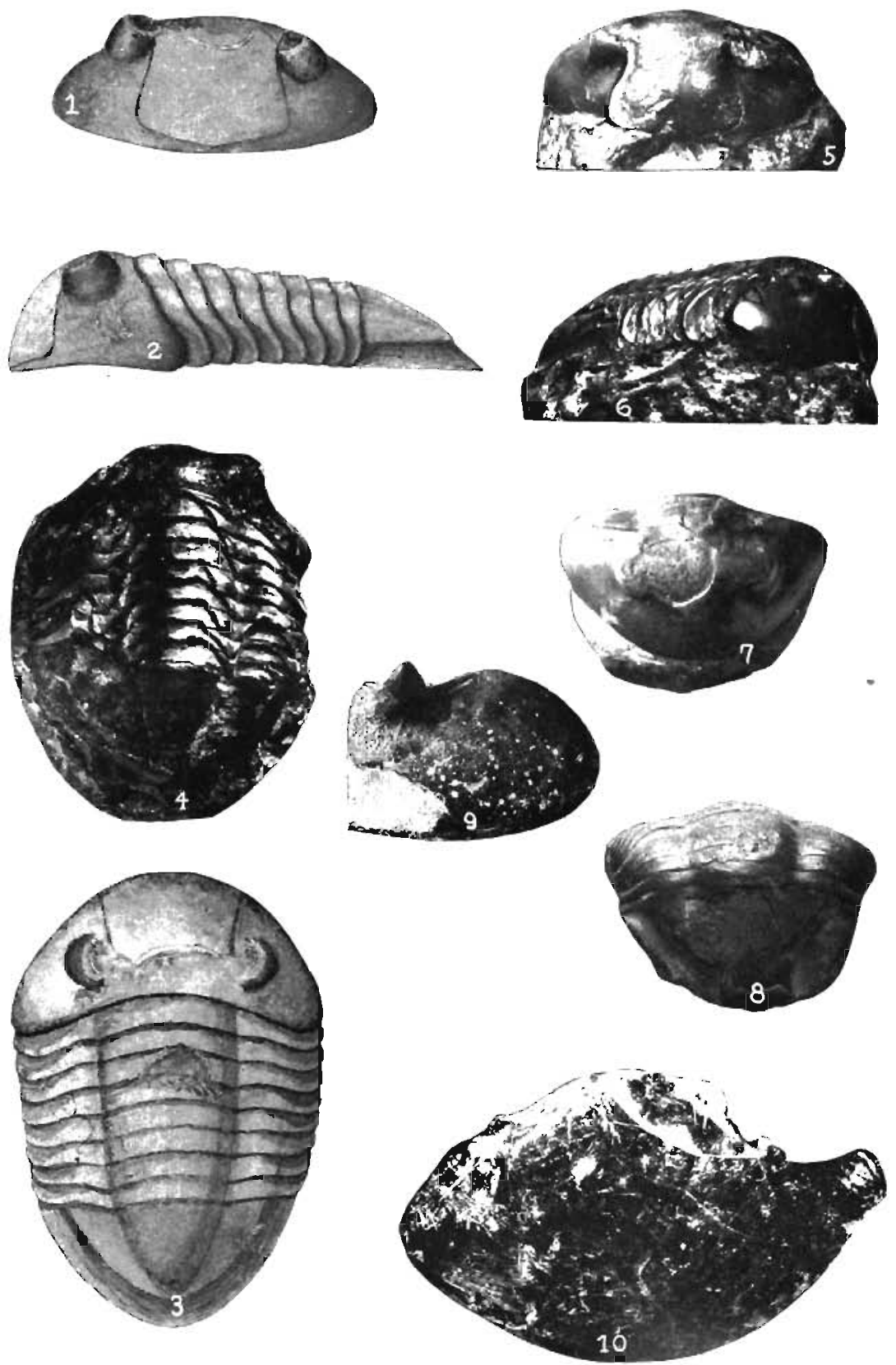
PLATE XV.

Isotelus gigas DeKay.

Fig. 1. Profile view of a large specimen showing Panderian organs on the thoracic segments. No. 9156. Times $1 / 2$.

Fig. 2. A large specimen showing the direction of the facial sutures. No. 9154. Times $1 / 2$.

Fig. 3. An imperfectly preserved specimen showing the hypostoma. No. 9155 .

Vogdesia gigas Raymond .206

Fig. 4. Dorsal view of an incomplete specimen. No. 9164.

Fig. 5. Lateral aspect of an enrolled specimen. Pygidium projecting beyond the cephalon. No. 9165 . 

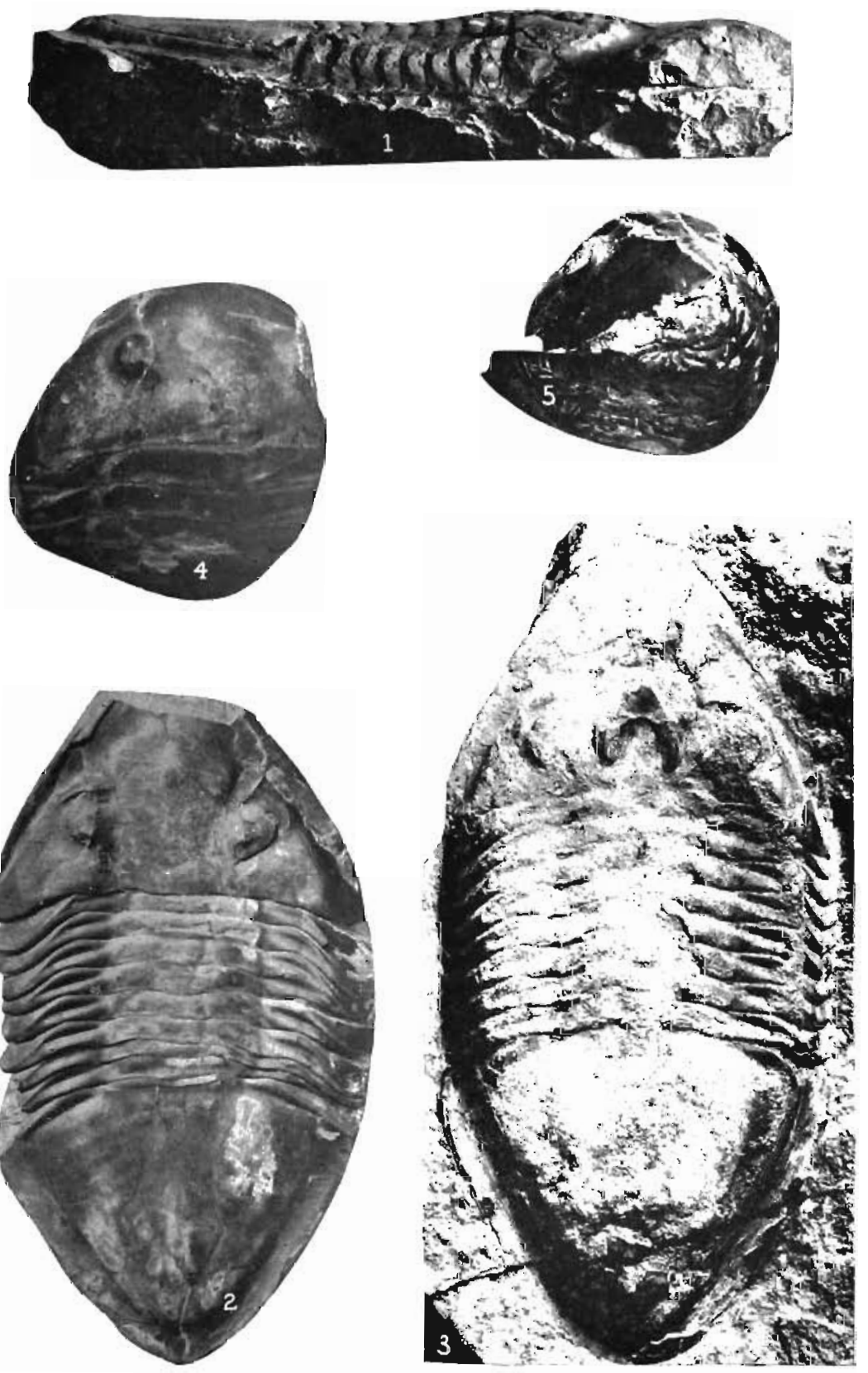


\section{PLATE XVI.}

Figs. 1-5. Vogdesia vigilans (Meek and Worthen.) 203

1, 2. Hront views of specimens No. 9190.

3. Profile view of figure 2 .

4, 5. Isateral aspects of two smaller specimens.

Fig's. 6-10. 1sotelus iowensis Owen

6. A hypostoma. No. 9142.

7. A large free cheek showing genal caeca. No. 9145 .

8. Ventral view of a cephalon showing hypostoma. No. 9147. 'This specimen was figured by Slocom, 1913, Plate XITI, fig. 2.

9. A glabella showing well the anterior configuration. No. 9143.

10. 'The inner surface of the test showing the direction of the facial sutures. No. 9140 .

Fig. 11. Busilicus barandi (Hall)

Fig. 11. Dorsal view of the thorax and the pygidium of an imperfectly preserved specimen. No. 9193. 

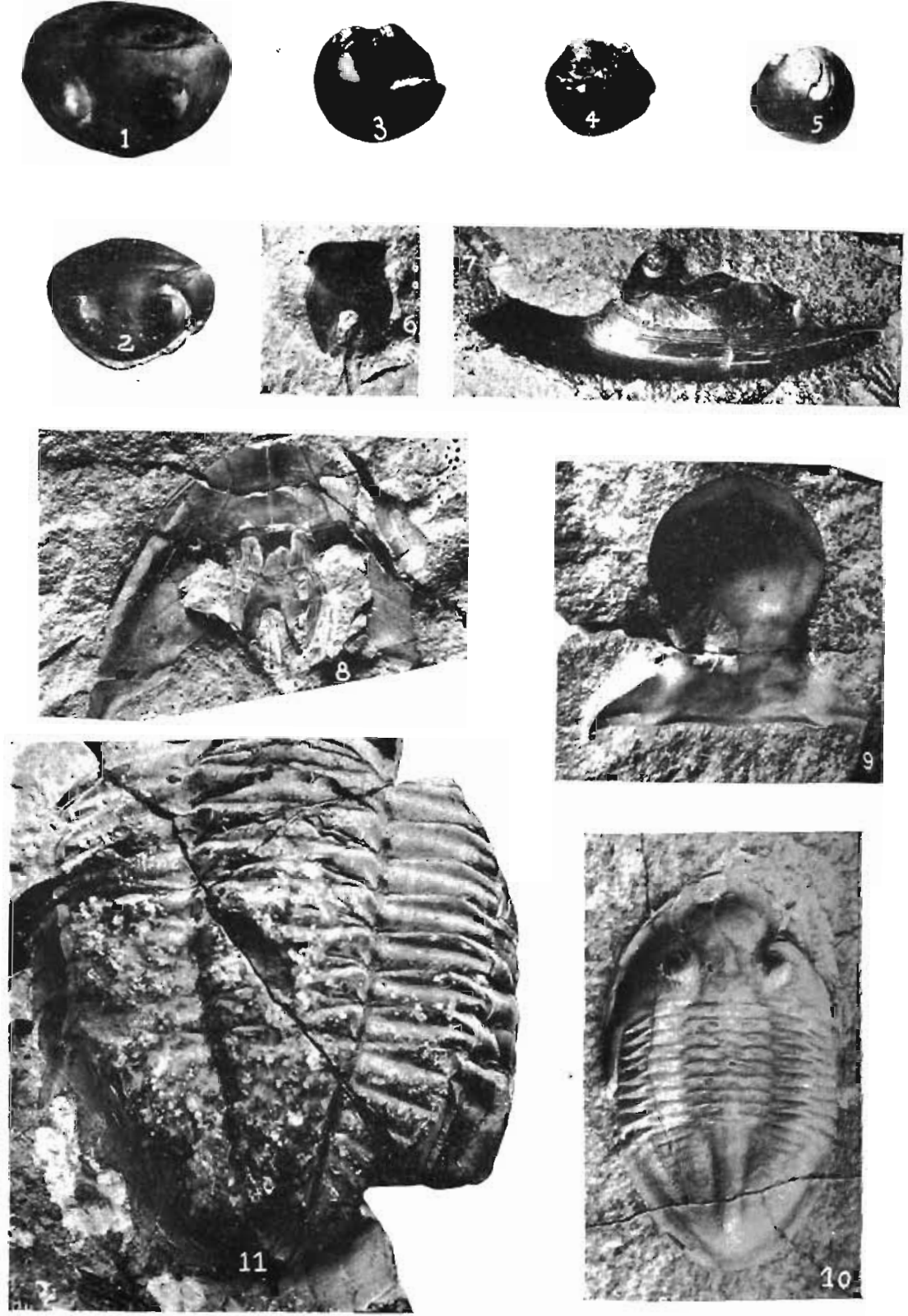


\section{PLATE XVII.}

Illaenus americanus (Billings)

Fig. 1. A cast of a pygidium from the Galena dolomite at Dubuque. No. 9173.

Bumastus milleri (Billings) .222

Fig. 2. A part of a cephalon showing the depressions opposite the eyes. No. 9191.

Thaleops ovata Conrad.

Fig. 3. Dorsal view of seven thoracic segments in conjunction with the pygidium. Note small size of the latter. No. 9195.

Fig. 4. A cephalon. No. 9197.

Fig. 5. A pygidium somewhat distorted. No. 9194.

Homotehs gratiosus Raymond.

Fig. 6. "Profile view of a specimen to show the absence of depressed border. The figure also shows the course of the facial suture, which is just within the margin in front of the glabella." After Raymond, 1911, Plate II, fig. 1.

Fig. 7. "The same specimen. Another view to show the short, wide cephalon, the wide axial lobe, and the large eyes." After Raymond, 1911, Plate II, fig. 2.

Isotelus rejuvenis Raymond

Fig. 8. Dorsal view of a part of the thorax and the pygidium showing the faint surface markings. No. 9146.

Fig. 9. A slab giving some evidence of the gregarious habit of this species. No. 9141. Natural size. 

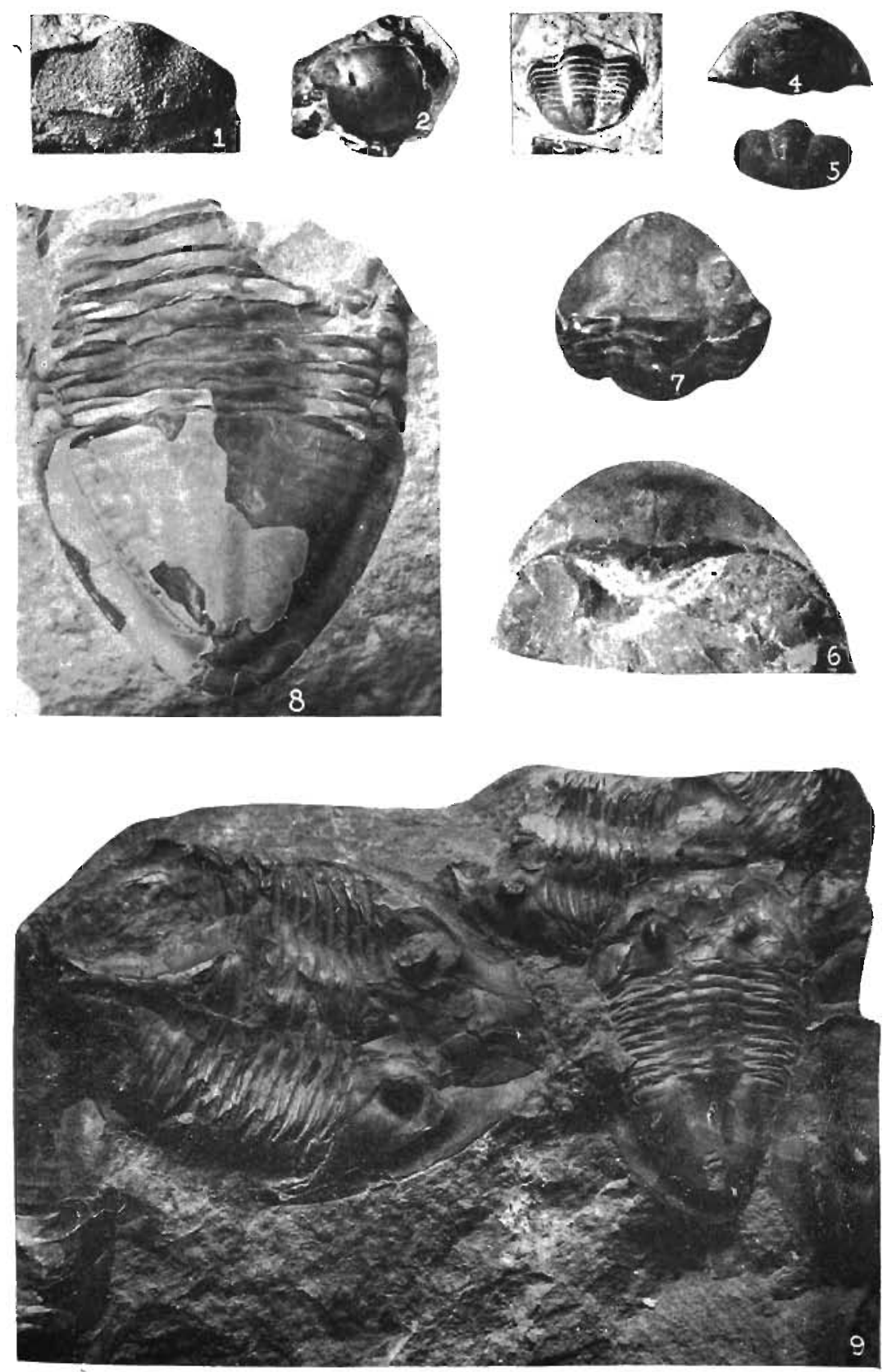
PLATE XVIII.

Cybeloides iowensis Slocom 233

Fig. 1. A nearly complete but somewhat imperfectly preserved specimen collected by Doctor Thomas. No. 9263.

C'eratocephala maquoketensis Walter.

Fig. 2. View of the inner surface of the test of the holotype. The pygidium is wanting. No. 9233.

Fig. 3. The same specimen greatly enlarged.

Encrinurus pernodosus Slocom.

*Fig. 4, 5. "Dorsal and lateral views of the holotype. Field Mus. Nat. Hist. No. P17038."

*Fig. 6. "A detached pygidium. Field Mus. Nat. Hist. No. P16930." After Slocom, 1913.

Amphilichas rhinoceros Slocom.

*Fig. 7 . "View of the inner surface of the shell of a cranidium. The type specimen." Field Mus. Nat. Hist. No. P11181. Times 6/7.

Fig. 8. "Outline restoration of the type specimen. Times 6/7.' After Slocom, 1913, Plate XV, fig. 6.

Amphilichas clermontensis Slocom.

Fig. 9. Dorsal view of a metatype from the Lower Maquoketa at Clermont. Collected by A. W. Slocom and presented to the University by him. No. 9207.

Bumastus beckeri Sloconl. 220

Fig. 10. Pygidial view of a large specimen collected by Doctor Thomas. No. 9258.

Fig. 11. Profile view of the same specimen.

Bumastus species 223

Fig. 12. A greatly flattened specimen preserved in a thinly laminated carbonaceous shale. No. 9159.

* Fipures obtained by coultesy of Field Museum of Natural History. They are after illustrations in their publication No. 171. 

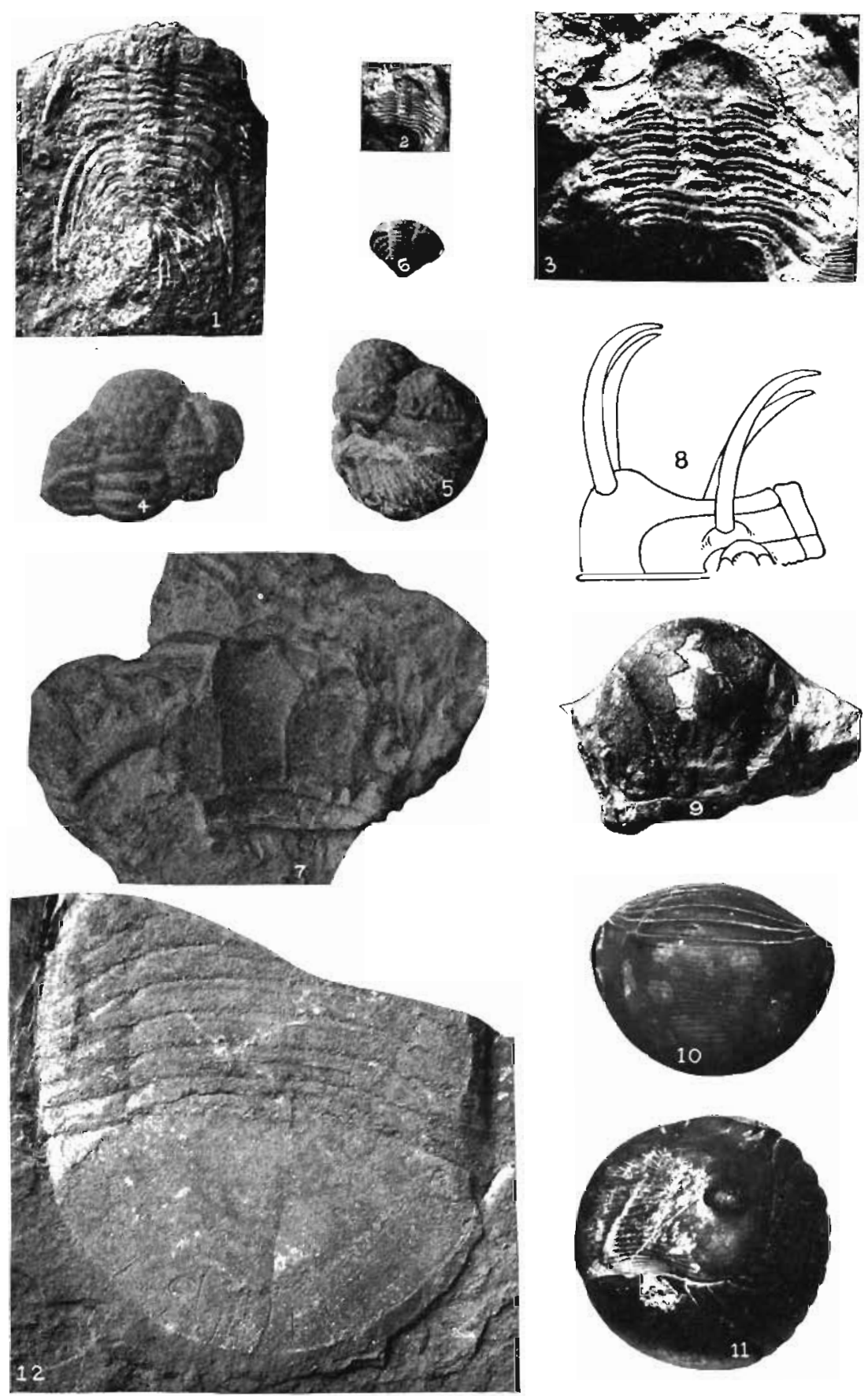


\section{PLATE XIX.}

Calymene mammillata Hall

Fig. 1. View of an incomplete cephalon showing the two manmilla-like nodes on the brim in front of the glabella. No. 9077. Times 4/3.

F'ig. 2. View of the inner surface of a fragmentary pygidium showing the broad U-shaped groove back of the axis. No. 9069. Times $4 / 3$.

Fig. 3. A complete pygidium. No. 9078. 'Times 4/3.

Calymene fayettensis Slocon.

Figures 4, 5 and 6 represent valious positions of the same specimen. No. 9283 .

Calymene gracilis Slocom

Fig. 7. View of a cranidium. The posterior limb of the fixed cheek is a trifle distorted. No. 9284.

Fig. 8. A detached pygidium. No. 9206.

Ceraurus pleurexanthemus Green.

Fig. 9. View of an incomplete cephalon. No. 9180.

Fig. 17. The inmer surface of Ceraurus pleurexanthemus showing a bifid genal spine. After Walcott, Bull. Mus. Comp. Zool. Harvard College, vol. VIII, no. 10, pl. IV, fig. 5. The figure is reduced times $1 / 2$. It is here introduced for comparison with fig. 11, which also has a bifid spine.

Ceraurus elginensis Slocom.

Fig. 10. Dorsal view of a cephalon which probably helongs to this species. The absence of the genal spines makes the specific reference somewhat doubtful. No. 9181.

Ceraunus hermanni Walter.

Fig. 11. Dorsal view showing a part of the thorax and the pygidium. Note the bifid left large spine of the pygidium. This specimen is now in the Mruseum of the Collector, Mr. Richard Herrmann, who kindly loaned it to the University for study.

Fig. 12. A pygidium of this species collected from the Platteville limestone at Sny Magill. No. 9182.

Figs. 13, 14, 15, representing a free cheek, a hypostoma and a cranidium respectively, are associated with the py- 

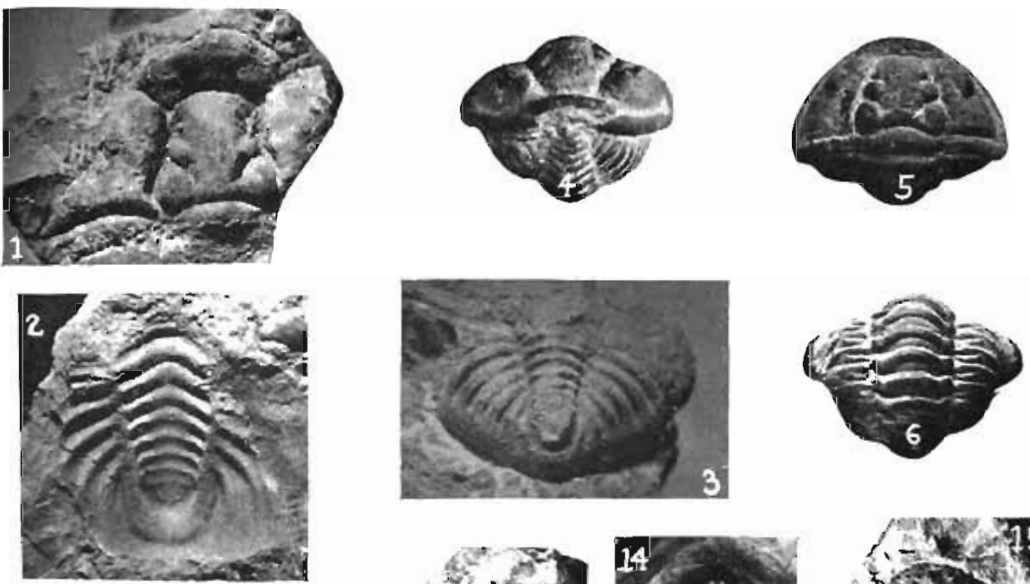

$\sum_{0 \rightarrow 1}$

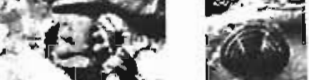

$\therefore \frac{3}{2} 8$ की
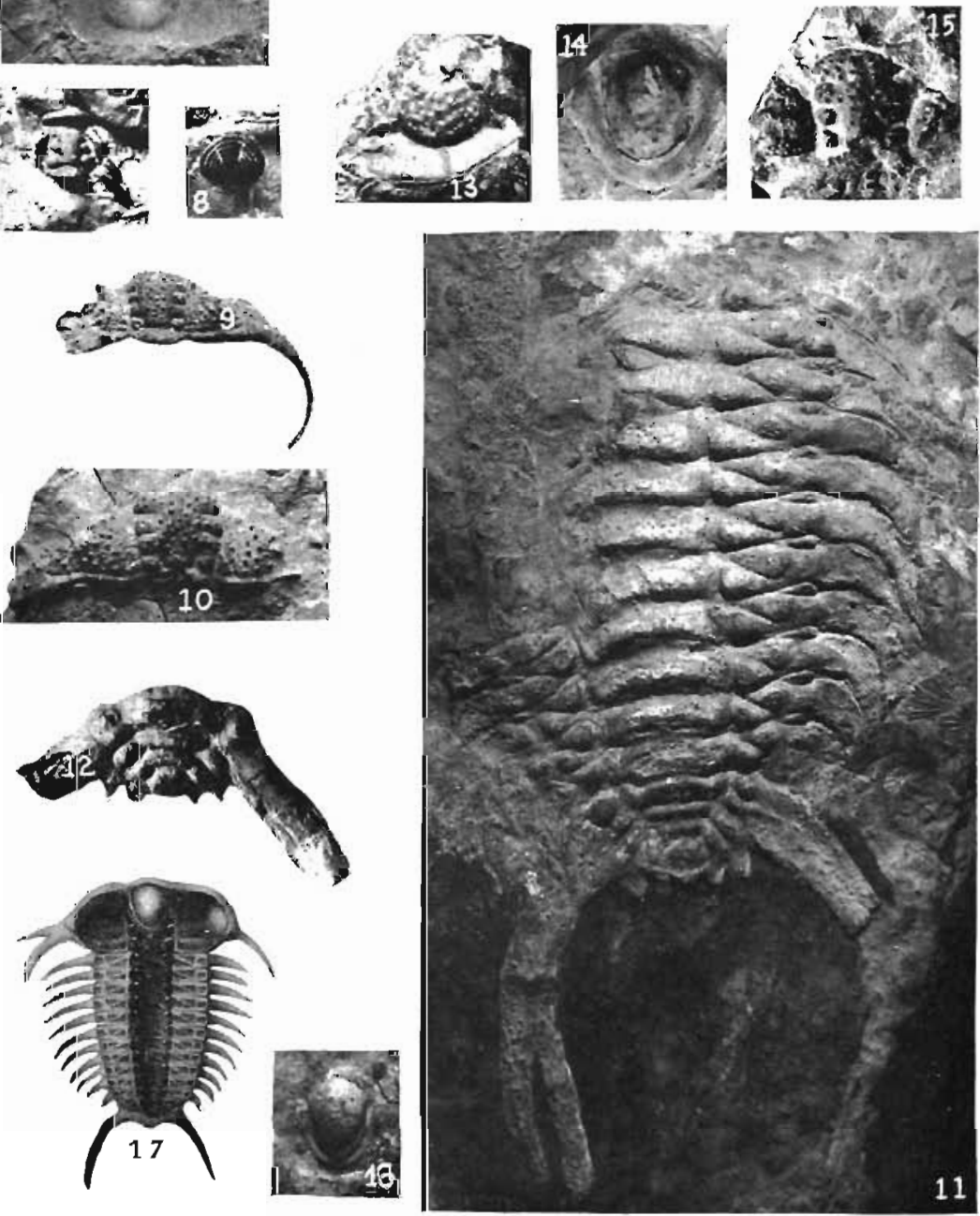
gidium of fig. 12 and are therefore tentatively referred to this species. These figures are of specimens No. 9179, $9132,9178$.

Ceraurus species.

Fig. 16. A hypostona of an unknown species. No. 9184.

\section{PLATE XX.}

The illustrations on this plate are from negatives in the Field Museum of Natural History. They are photograplis of the specimens described and figured by Slocom, 1916.

Pterygometopus fredricki Slocom. .256

Fig. 1. The type specimen, xT/6. Field Musem No. P 17024.

Fig. 2. An enrolled specinen, x3. In the collection of Mr. A. G. Becker.

Fig. 3. A dorsal view of the sanie, $x 3$.

Sphatocoryphe muquokensis slocom 2.54

Fig. 4. Lateral view of the holotype, x3. Field Musemm No. P 11152 A.

5. Dorsal view of the sane.

Fig. 6. Ventral view of a pygidiun from Lilgin, x5. Field Musem No. P 17051.

Ceranus milleramus Miller and Gurley

Fig. 7. The type specimen, $x 4 / 3$. University of Chicago No. 6062.

Pterygometopus larrabeei slocom

Fig. 8. Dorsal view of the holotype, $x 4 / 3$. Field Museum No. P 11256.

Fig. 9. Pygidium associated with the holotype, $x 4 / 3$.

Ceraurinus icarus (Billings).

Fig. 10 and 11. Anterior and posterior dorsal views of an enrolled specimen, $\times 8 / 5$. In the collection of $\mathrm{Mr}$. A. G. Becker.

Fig. 12. Ventral view of a complete pygidium. Field Nhuseum No. P 11150.

Fig. 13. An imperfect cranidium showing the outline of the facial suture, x3/2. Field Museum No. P 11150. 

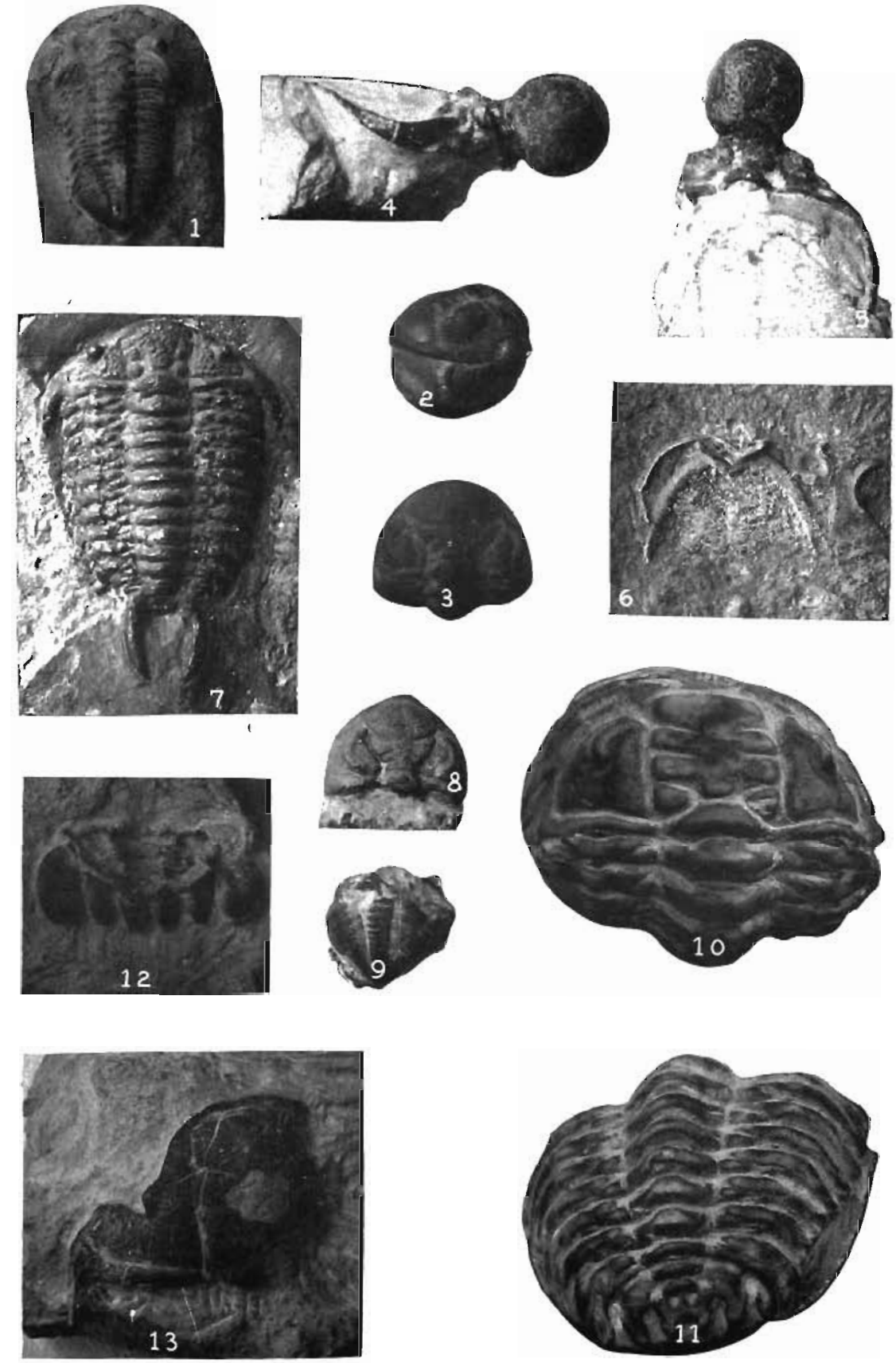


\section{PLATE XXI.}

Illaenus imperator Hall.

Fig. 1. Dorsal view of a cephalon. No. 9221.

Fig. 2. Profile view of the same to show dorso-median curvature.

Fig. 3. View of a smaller cephalon showing a portion of the free cheek, a part of which has been pushed under the glabella. No. 9218.

Illaenus slocomi Walter.

Fig. 4. Profile view of the type cranidium, No. 9215.

Fig. 5. Dorsal view of the same specimen.

Fig. 6. A large nearly perfect pygidium which occurs in association with cranidia of the type of this species. No. 9220.

Illaenus lobatus Walter. 265

Fig. 7. Dorsal aspect of the type pygidium. No. 9230.

Fig. 8. Profile view of the same. 

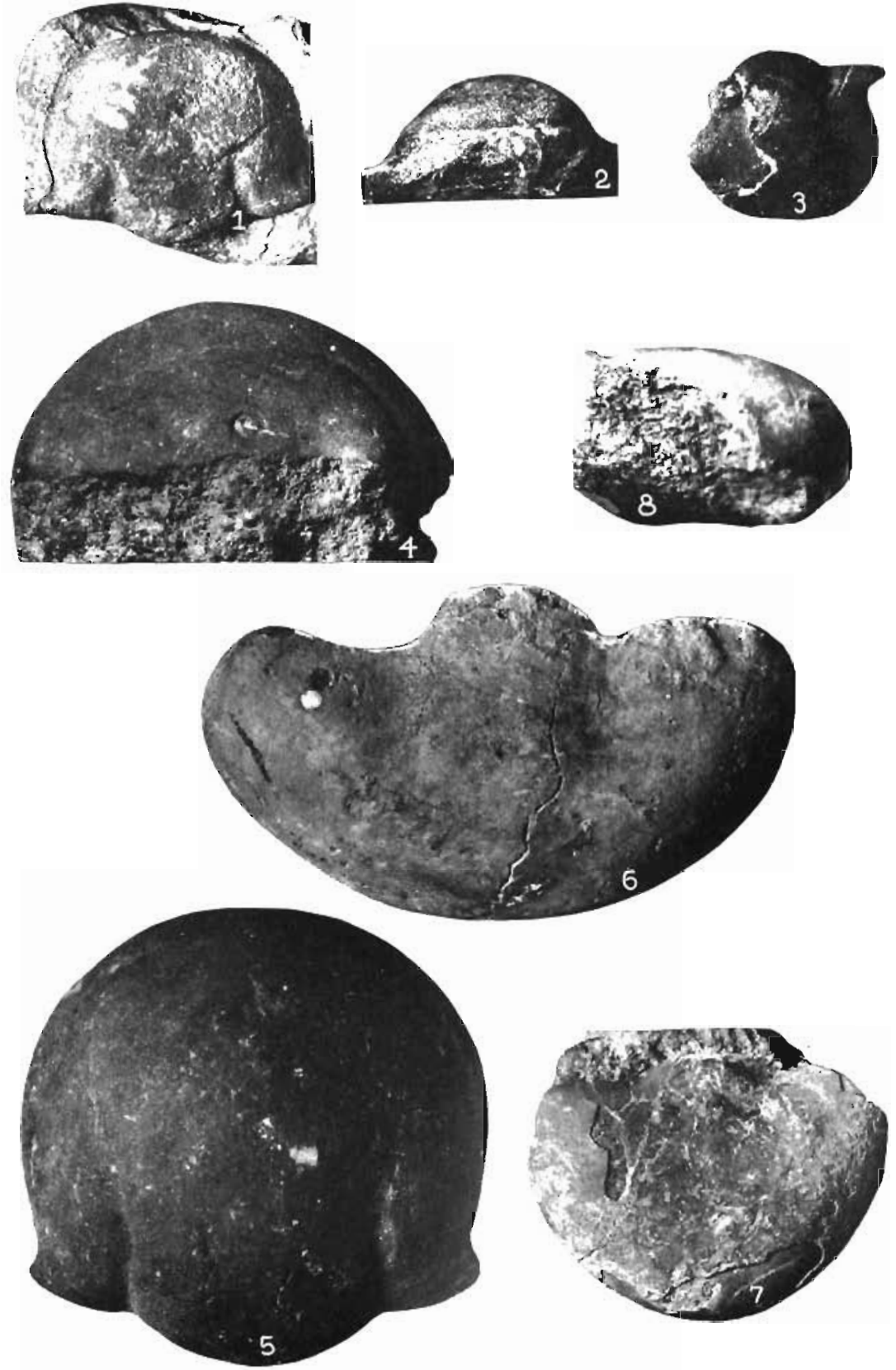


\section{PLATE XXII.}

Illaenus ioxus Hall.

Fig. 1. View of an incomplete cranidium. No. 9231. Illaenus triangularis Walter. 264

Fig. 2. Profile view of the type pygidium. No. 9226.

Fig. 3. Longitudinal profile along the dorso-median line of the same specimen.

Fig. 4. Dorsal view of the type pygidium. Goldius laphami (Whitfield)

Fig. 5. View of a small pygidium, No. 9048, from the Niagaran near Central City.

Fig. 6. View of a much larger specimen. No. 9049, from the Niagaran dolomite near Clinton.

Fig. 7. A pygidium. No. 9052, from the nondolomitic beds of the Hopkinton stage, in the south half of section 20, Coffins Grove township, Delaware county. Collected by Professor Thomas. 

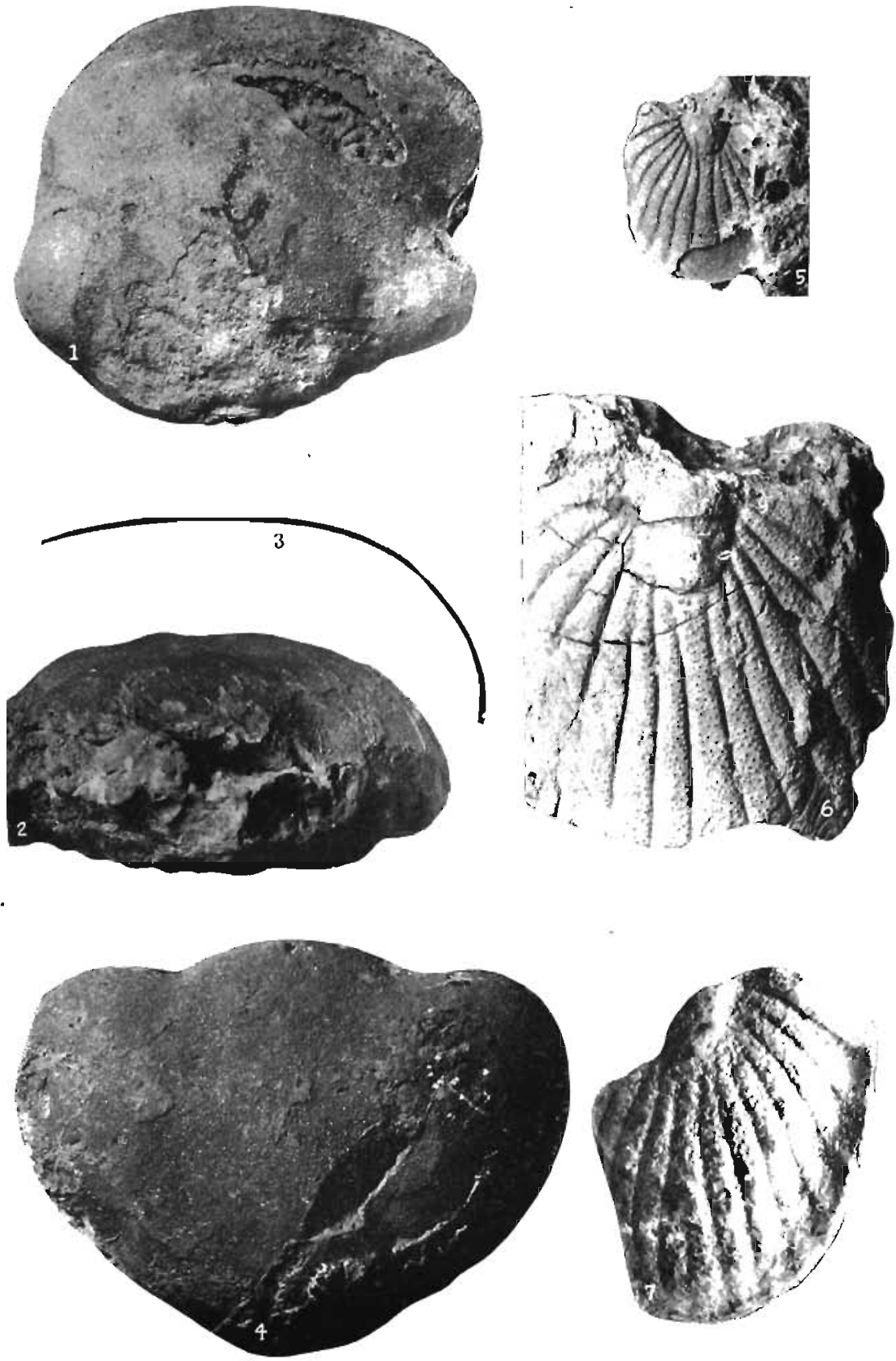


\section{PLATE XXIII.}

Metopolichas ionensis Walter. 268

Fig. 1. Dorsal view of the holotype cephalon. The furrows have been marked in ink. No. 9043.

Fig. 2. Lateral view of the same specimen. Here also the furrows are outlined in ink.

Arctinurus obvius (Hall)

Fig. 3. "View of the glabella and lateral lobes of a specimen from the Niagaran limestone at Lyons (Clinton), Iowa."' After Hall, 1867, pl. 25, fig. 19.

Figs. 4-9. Arctinurus anamosa Walter.

4. Dorsal view of a large incomplete cephalon showing well the surface markings. No. 9045.

5. A profile view of the same.

6. A fragment of an even larger cephalon. No. 9046.

7. Dorsal view of the type specimen. Note absence of occipital lobes. The furrows are outlined in ink. No. 9044.

8. A profile view of the same. The furrows are here outlined in ink.

9. A large hypostoma of an Arctinurus, probably that of $A$. anamosa because of its large size and its occurrence in association with the above heads. No. 9047.

Encrinurus ornatus Hall and Whitfield.

Fig. 11. View of a nearly perfectly preserved specimen, No. 9210, loaned to the University through the courtesy of Professor Norton of Cornell College.

Fig. 12. This represents the impression of the inner surface, giving an idea of the prominent eyes. No. 9211.

Figs. 13, 14, 15. Three pygidia showing a variation in the position of the nodes on the axis. All these specimens are from a limited horizon in the Anamosa-LeClaire, at the Plattner-Kirby quarry at Mount Vernon.

Dalmanites platycaudatus Weller. 279

Fig. 10. Dorsal view of an ineomplete cranidium. No. 9059 . 

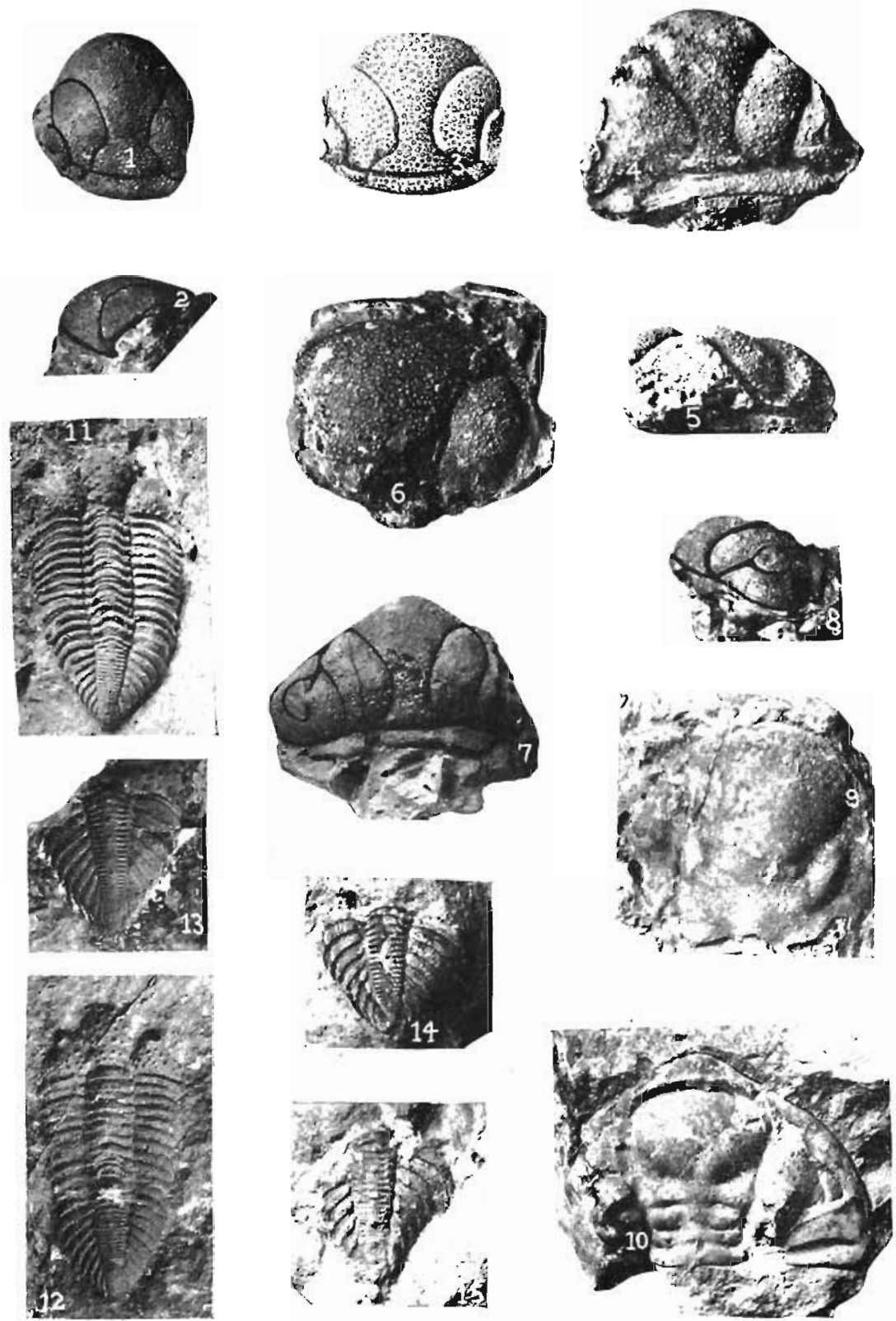


\section{PLATE XXIV.}

Calymene niagarensis Hall 275

Fig. 1. Dorsal view of an average size specimen. No. 9085.

Fig. 2. Side view of another specimen to show the characteristic "sway-back." No. 9086.

Fig. 3. Lateral view of a giant form which also is characterized by the sway-back.

Fig. 4. Dorsal view of the same specimen. This specimen was collected by Mrr. Wm. Matz of Clinton, in the Anamosa-LeClaire at Mount Vernon. Mr. Matz presented the specimen to Father Ulrich A. Hauber, of St. Ambrose College at Davenport, where the specimen now is. Through the courtesy of Father Hauber the specimen was made available for comparison and study.

Fig. 5. A dorsal view of a large silicified specinen from the Niagaran limestone at Farley. No. 9057.

Cheirums niagarensis (Hall) 278

Fig. 6. A view of a fragment of the cephalon. No. 9212.

\section{Cybele species}

Fig. 7. View of an ineomplete pygidium. No. 9260. 

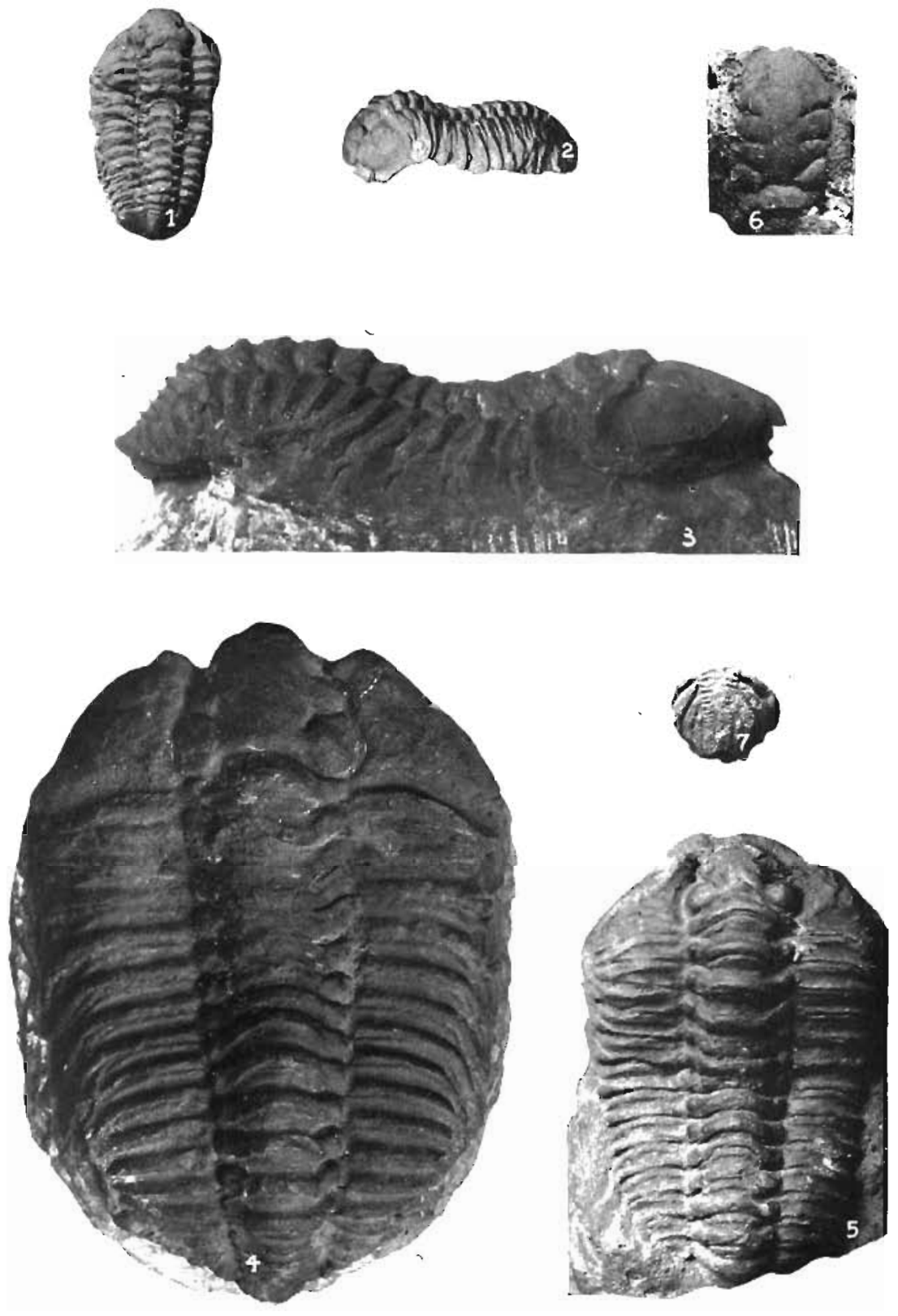


\section{PLATE XXV.}

Ceraurus savagei Walter

Fig. 1. Cranidium imperfectly preserved. Note the absence of genal spines. No. 9183. The holotype.

Goldius thomasi Walter 280

Fig. 2. A view of the type cranidium showing the occipital spine and narrow frontal margin. No. 9085.

Fig. 3. An enlarged view of the same specimen.

Fig. 4. A detached pygidiun associated with the cranidium. No. 9087.

$$
\text { Proetus prouti Shumard. }
$$

Fig. 5. Dorsal aspect of an average size specimen showing the long genal spine on the left side. No. 9089. From Davenport.

Fig. 6. View of another specimen from which the genal spines have been partly broken away. No. 9287.

Fig. 7. Profile view of the same. Collected by Mr. M. A. Stainbrook in the Cedar Valley, at Brandon.

Fig. 8. View of a detached pygidium.

Proetus nortoni Walter.

Fig. 9. View of a cranidium showing well the surface markings. No. 9098.

Fig. 10. Dorsal aspect of the type specimen with pygidium deflected at right angles. No. 9095.

Fig. 11. View of the pygidium of the same specimen showing a part of the deflected thorax and cephalon.

$$
\text { Proetus clarus Hall. }
$$

Fig. 12. Dorsal view of the cephalon. Note the granular surface markings over the base of the glabella. No. 9090.

Fig. 13. Profile view of the same specimen.

$$
\text { Proetus roui (Green) }
$$
291

Fig. 14. Dorsal view of a fragmentary specimen. No. 9129.

Fig. 15. Profile view of the same specimen.

Proetus occiden. Hall .294

Fig. 16. View of a detached pygidium. No. 9126.

Fig. 17. View of another detached pygidium. No. 9125 . 

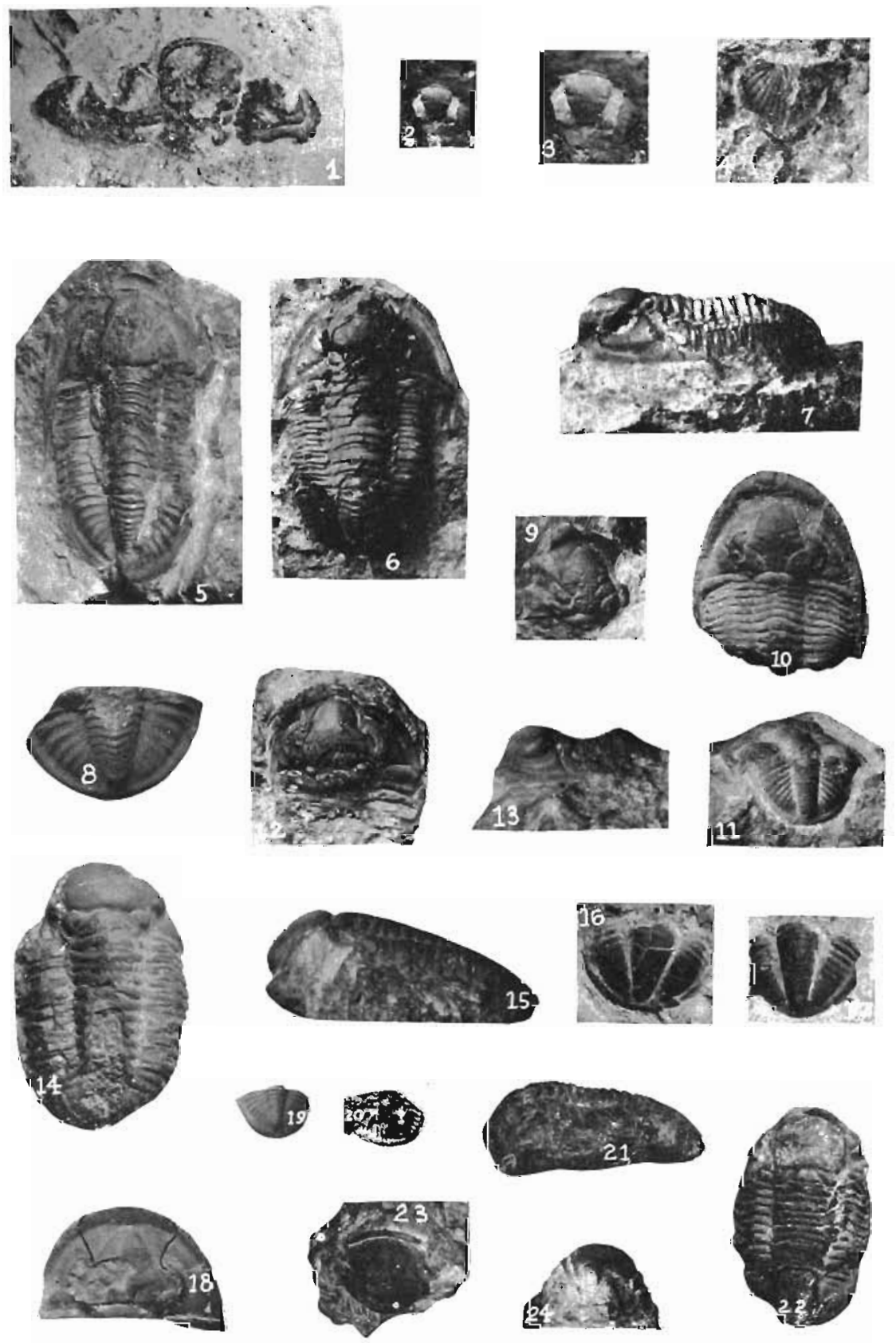
PLATE XXV Continued.

Proetus haldemani Hall.

Fig. 18. View of a separate cephalon. Facial sutures outlined in ink. No. 9093.

Fig. 19. View of a small detached pygidium. No. 9096.

Proetus species 303

Fig. 20. A small fragnentary pygidium similar to that of Phacthonide's gemmaeus Hall in its surface markjngs but differing from it in having a concave border. No. 9104.

Proctus arietinus Walter.

Fig. 21. Profi]e view of the type specimen showing the rather large, abruptly deflected head. No. 9122.

Fig. 22. Dorsal aspect of the same specimen.

Proetus bumastoides Walter. 301

Fig. 23. Dorsal view of the type cranidium. No. 9115.

Fig. 24. Profile view of the same.

\section{PLATE XXVI.}

Figs. 1-9. Proetus searighti Walter.

1. Profile view of type cephalon. No. 9106.

2. Dorsal view of same. The right free cheek and the anterior border are missing.

3. Dorsal view of an incomplete cephalon showing the concavo frontal margin. No. 9131.

4. A pygidium with left side exfoliated. Right side complete and showing granular surface nnarkings on the pleural ccoments. No. 9130.

5. A somewhat larger pygidium. No. 9110.

6. A portion of a small cephalon showing the anterior margin.

7. View of a free chcek. No. 9107.

8. Another pygidium in enjunction with one thoracic segnent. No. 9278.

9. Profile view of sante.

Proetus ef. P. missouriensis Shumarel.

Fig. 10. The cranidium collected by C. A. White and 
Iona Geological SuRvey
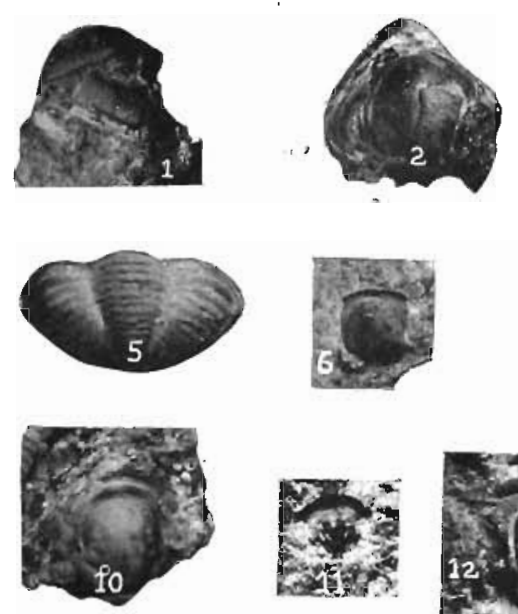

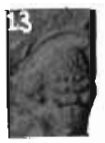
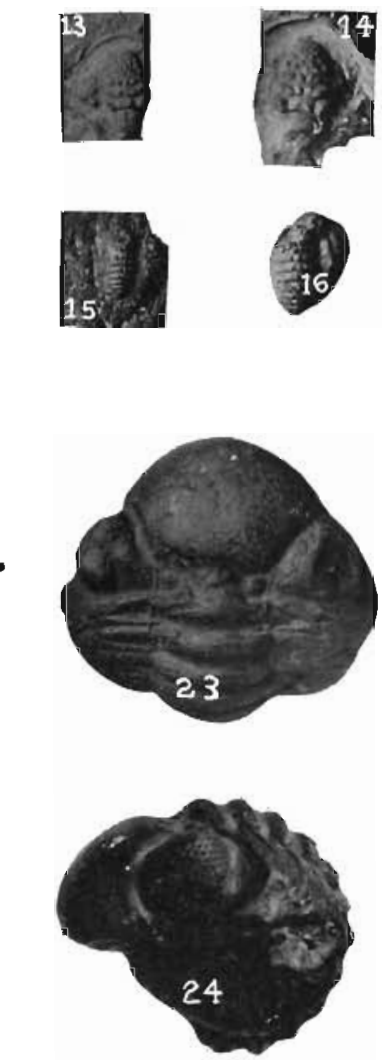
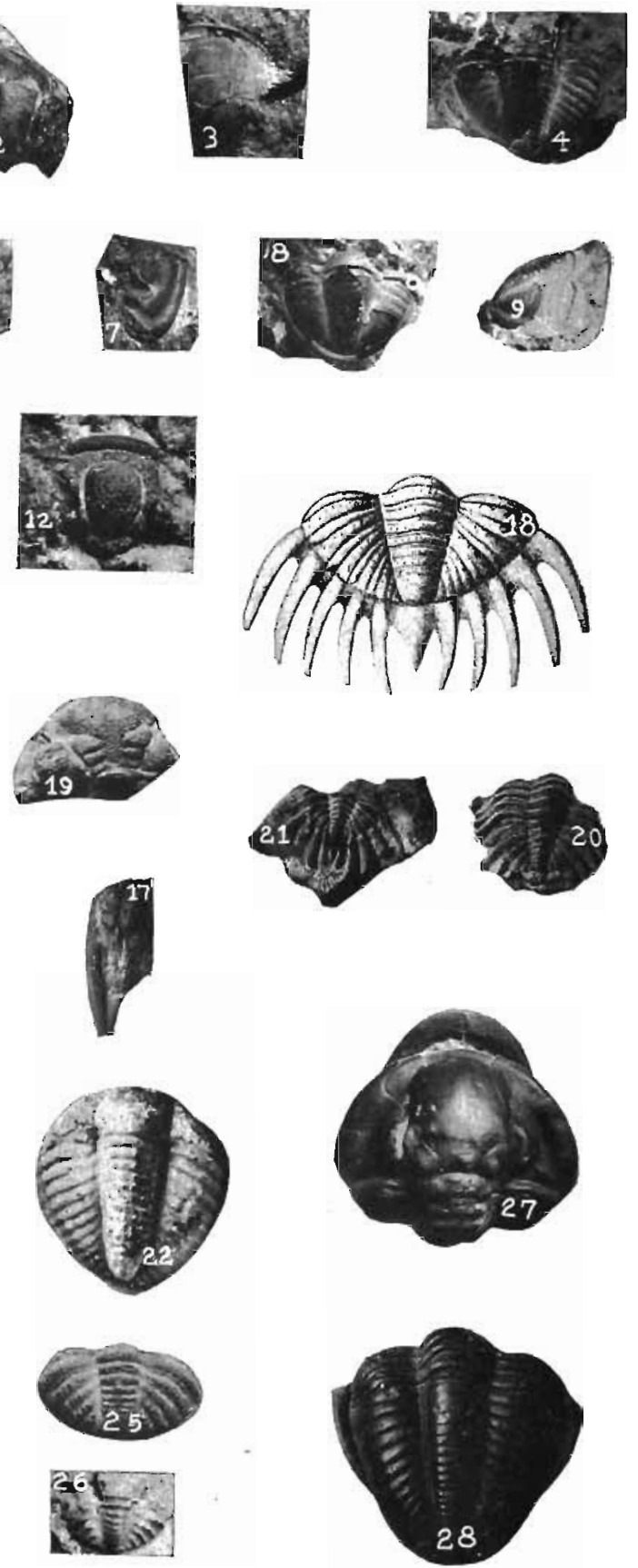


\section{PLATE XXVI Continued.}

referred by Winchell to Phillipsia meramecensis. This specimen was kindly loaned to the University for study. It is now in the Paleontology Collection at the University of Michigan, Mus. No. 4908. The figure is enlarged times $9 / 5$.

Cyphaspis raripustulosus Walter 304

Fig. 11. Dorsal view of the cranidium which is the holotype. No. 9113. Collected by Merrill A. Stainbrook.

Cyphaspis brandonensis Walter. 305

Fig. 12. Enlarged view of the holotype cranidium. No. 9114. Times 4.

Figs. 13-17. Proetides insignis (Winchell)

Figures 13 and 14 are two incomplete cranidia, 15 and 16 represent two incomplete pygidia, and 17 is a fragmentary free cheek. This is the material collected by C. A. White and described by Winchell as Phillipsia insignis. Figures 13 and 14 represent the genotyes of the new genus Proetides. These specimens were obtained for study through the courtesy of Dr. G. M. Ehlers of the University of Michigan. They are now in the Paleontology Collection at the University of Michigan, Mus. No. 2191.

Asteropyge barrisi (Hall) 306

Fig. 18. "A pygidium, enlarged to three diameters, and showing the round, terete marginal spines, and the conspicuous terminal spine." After Hall, 1888, Pl. XVIA, fig. 18.

Figs. 19-21. Asteropyge fitzpatricki Walter. 307

19. An incomplete cranidium. No. 9081.

20. The pygidium and a part of the thorax of the same.

21. The type pygidium showing nearly all the marginal spines and the small terminal spine. No. 9080.

Phillipsia tuberculata Meek and Worthen

Fig. 22. A nearly perfectly preserved pygidium from the Burlington limestone near Fort Madison. This is now in the collection of the State Historical Department at Des Moines, Mus. Cat. No. 4774.

Figs. 23-26. Phacops rana Green. 310

23. Dorsal view of a large enrolled specimen, No. 9116, 


\section{PLATE XXVI CONTINUED}

kindly presented to the University by Mr. A. N. Harbert of Shellsburg.

24. A profile view of the same specimen.

25. A pygidium of a young specimen showing the character of the surface markings. No. 9117. Enlarged times 2.

26. A small exfoliated pygidium appearing very different from figure 25. Except for the annulations all the surface markings are lost. No. 9118.

Phillipsia major Shumard.

Fig. 27. Cephalic aspect of a nearly perfect specimen showing the facial sutures and the pygidium projecting beyond the cephalon. The genal spines are wanting. No. 9040.

Fig. 28. Pygidial aspect of the same enrolled specimen. This specimen was kindly loaned to the University for study by Prof. T. J. Fitzpatrick.

\section{PLATE XXVII.}

Griffithides wilsoni Walter. 324

Fig. 1. A nearly complete cranidium somewhat distorted and with genal spines missing. The type specimen, No. 9082. Times two diameters.

Fig. 2. Pygidium of the same.

Fig. 3. A nearly perfect pygidium, No. 9024, showing sharp definition of segments and distinct submarginal groove.

Fig. 4. Specimen No. 9039, originally described by Dr. A. O. Thomas as Phillipsia species.

Fig. 5. Pygidium showing abnormal segmentation of pleuræ. No. 9023.

Fig. 6. Enlargement of the same.

Fig. 7. A free cheek, and fig. 8, a pygidium, both associated in the Ste. Genevieve limestone, at Ste. Genevieve, Missouri. The pygidium shows the sharp definition of segments as well as the marginal groove. These specimens and a number of others, not figured here, were 


\section{PLATE XXVII Continued}

kindly loaned to the University for study. They are now at the United States National Museum.

Griffithides wilsoni var. genevievensis Walter....327

Fig. 9. The type specimen, No. 9056, showing smooth ungrooved margin and faint definition of segments.

Fig. 10. Another pygidiun, No. 9083, for comparison.

Griffithides scitulus Meek and Worthen. 331

Fig. 11. Incomplete cranidium, No. 9035, sufficiently preserved to show generic characters.

Fig. 12. Pygidium of same and a part of the thorax somew hat distorted.

Fig. 13. A free cheek. No. 9214.

Fig. 14. A nearly perfectly preserved pygidium. No. 9031.

Lepidocoleus iouensis Thomas

Fig. 15. Tateral view of type. No.9265a.

Fig. 16. Dorsal view of a somewhat larger specimen. No. 9265łs.

Griffithides portlocki Meek and Worthen 321

Fig. 17. A complete but somewhat distorted cephalon. No. 9042 .

Fig. 18. A complete pygidium. No. 9032.

Fig. 19. Profile view of figure 18 showing nodelile enlargement of the terminal axial segment.

Palaeopalaemon iowensis Walter

Fig. 20. Lateral aspect of the holotype. No. 9277.

Isotelus gigas DeKay

Fig. 21. Dorsal view of a small specimen to show the anterior configuration of the glabella. No.9176. See also Plate XV, figures 1-3.

Ectenaspis beckeri (Slocom) 201

Fig. 22. A rather large pygidium showing well the posterior elongation of the concave marginal border. See also Plate XIII, figures 8 and 9. 
Iowa Grological Survey

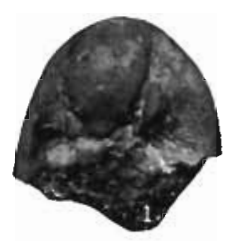

这数
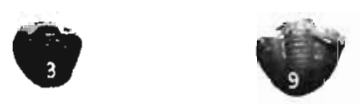

3
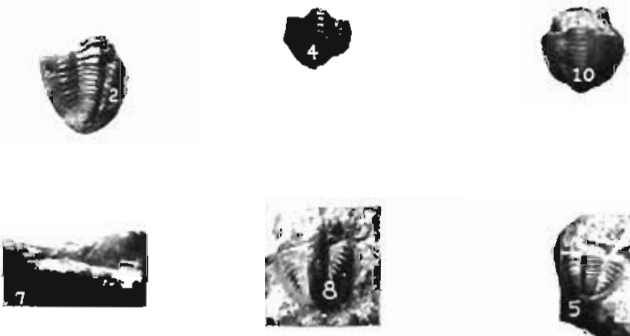
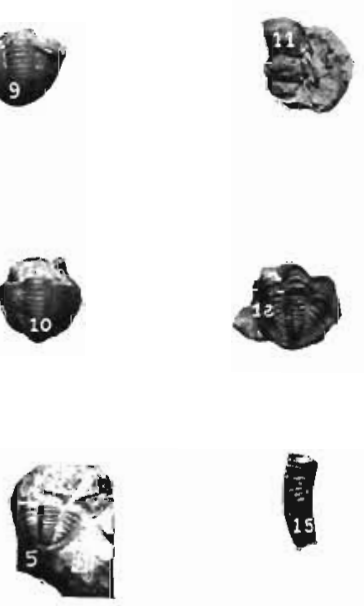

POATE XXVII
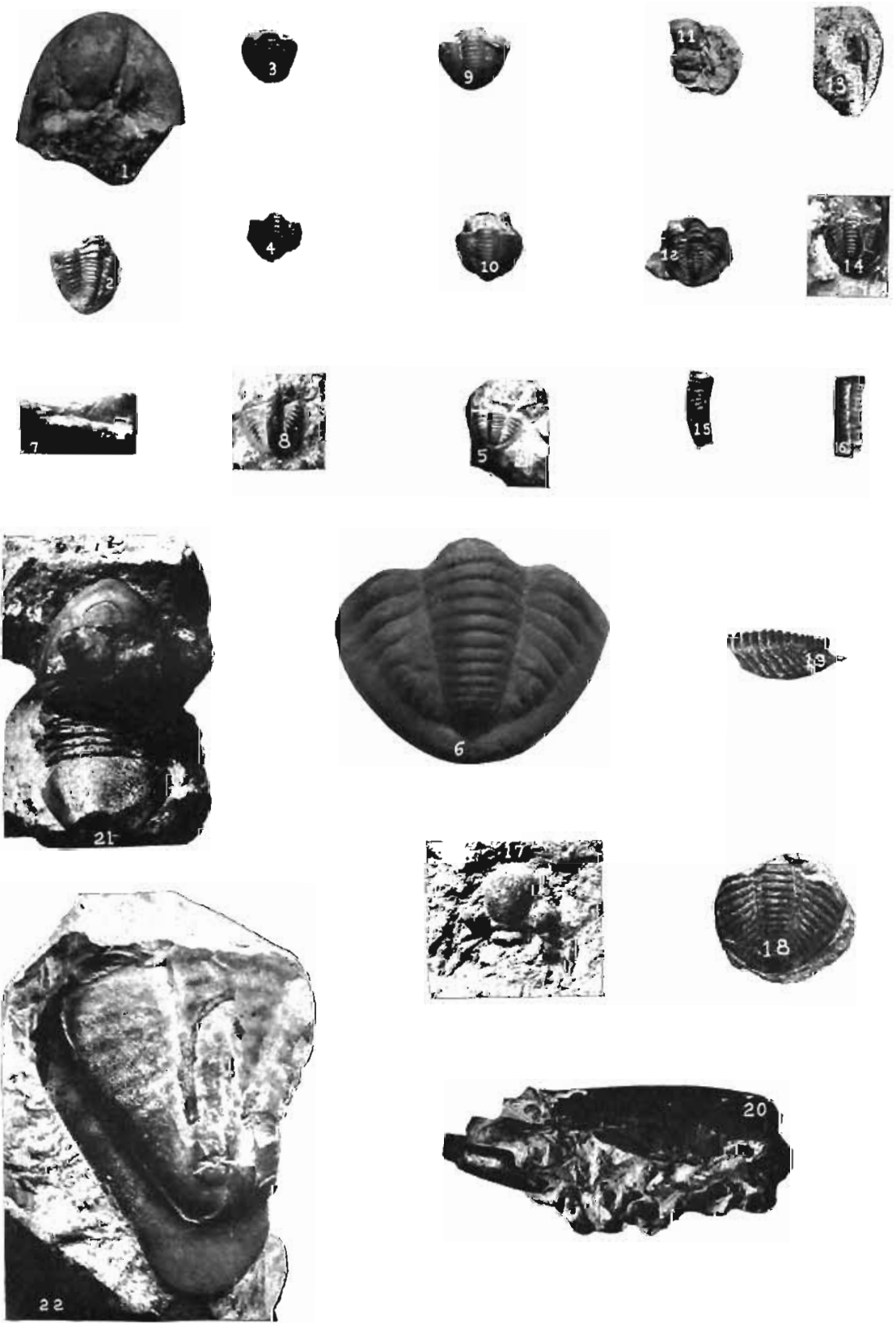
